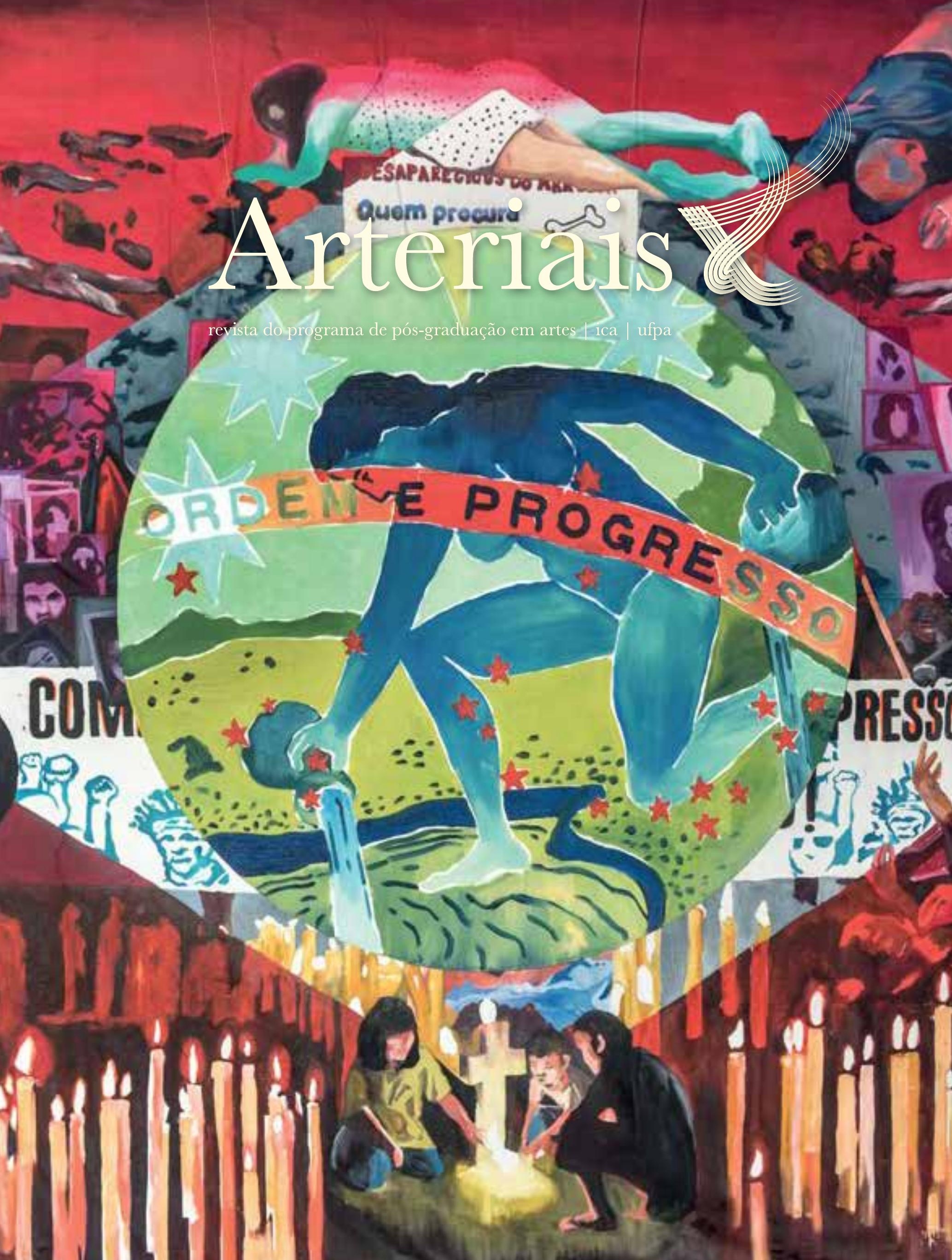


Todos os esforços foram feitos para contactar com os detentores dos direitos das imagens. Em caso de omissão, faremos todos os ajustes possíveis na primeira oportunidade. Esta é uma publicação sem fins lucrativos, e encontra-se livre de pagamentos de direito de autor no Brasil, protegida pela Lei № 9.610, Título III, Cap. IV, Art. 46, Inciso VIII. 


\section{Arteriais}

revista do programa de pós-graduação em artes | ica | ufpa 
MANESCHY, Orlando, MARTINS, Bene Afonso, MENDES, Ana Flávia (org.)

Revista Arteriais, Ano 05, n. 08 - Belém, Pará, Programa de Pós-Graduação em Artes/Instituto de Ciências da Arte/ UFPA, junho de 2019 $253 \mathrm{p}$.

ISSN 2446-5356
1. Artes Visuais
2. Artes Cênicas
3. Música
4. História e Teoria da Arte

I. Universidade Federal do Pará 


\section{ARTERIAIS $\gg>$}

Ano 04 | n. 08 | 2019

Revista do Programa de Pós-Graduação em Artes | ICA | UFPA

Pró-Reitoria de Pesquisa | Periódicos - Portal de Revistas Científicas da UfPA

\section{Reitor}

Prof. Dr. Emmanuel Zagury Tourinho

\section{Vice-Reitor}

Prof. Dr. Gilmar Pereira da Silva

Pró-Reitora de Pós-Graduação e Pesquisa

Profa. Dra. Maria Iracilda da Cunha Sampaio

\section{Diretora de Pesquisa}

Profa. Dra. Germana Maria Araújo Sales

Diretora Geral do Instituto de Ciências da Arte

Adriana Azulay

Diretor Adjunto do Instituto de Ciências da Arte

Joel Cardoso

Coordenadora do Programa de Pós-Graduação em Artes

Ana Flávia Mendes Sapucahy

Vice-Coordenador do Programa de Pós-Graduação em Artes

José Afonso Medeiros de Souza

Coordenadora do PROF-ARTES/ Mestrado Profissional

Denis Bezerra

\section{FICHA TÉCNICA}

\section{Editores científicos}

Orlando Maneschy | Ana Flávia Mendes Sapucahy

\section{Editores Responsáveis}

Keyla Sobral | Breno Filo | Sávio Stoco (Editor Convidado)

\section{Bolsista do programa}

Keyla Sobral

\section{Comitê editorial}

Orlando Maneschy | Ana Flávia Mendes Sapucahy 


\section{Conselho Editorial}

\section{Visuais}

Afonso Medeiros, Universidade Federal do Pará, Belém-PA. André Parente, Universidade Federal do Rio de Janeiro, Rio de Janeiro-RJ. Cristina Freire, Universidade de São Paulo, São Paulo-SP. Elisa Souza Martinez, Universidade de Brasília, Brasília-DF. Gilberto Prado, Universidade de São Paulo, São Paulo-SP. Jens Michael Baungarten, Universidade Federal de São Paulo, São Paulo-SP. João Paulo Queiroz, Faculdade de Belas-Artes da Universidade de Lisboa, Lisboa - Portugal. Lúcia Pimentel, Universidade Federal de Minas Gerais, Belo Horizonte-MG. Mabe Bethônico, Universidade Federal de Minas Gerais, Belo Horizonte-MG. Maria Beatriz Medeiros, Universidade de Brasília, Brasília-DF. Maria Ivone dos Santos, Universidade Federal do Rio Grande do Sul, Porto Alegre-RS. Maria Luiza Távora, Universidade Federal do Rio de Janeiro, Rio de Janeiro-RJ. Marisa Mokarzel, Universidade da Amazônia, Belém-PA.

Norval Baitello Júnior, Pontifícia Universidade Católica de São Paulo, São Paulo-SP. Orlando Maneschy, Universidade Federal do Pará, Belém-PA. Rosana Horio Monteiro, Universidade Federal de Goiás, Goiânia-GO. Sérgio Basbaum, Pontifícia Universidade Católica de São Paulo, São Paulo-SP. Valzeli Sampaio, Universidade Federal do Pará, Belém-PA.

\section{Musicais}

Carlos Augusto Vasconcelos Pires, Universidade Federal do Pará, Belém-PA. Carlos Sandroni, Universidade Federal de Pernambuco, Recife-PE.

Catarina Domenici, Universidade Federal do Rio Grande do Sul, Porto Alegre-RS.

Celso Loureiro Chaves, Universidade Federal do Rio Grande do Sul, Porto Alegre-RS. Cristina Gerling, Universidade Federal do Rio Grande do Sul, Porto Alegre-RS.

Cristina Tourinho, Universidade Federal da Bahia, Salvador-BA.

Diana Santiago, Universidade Federal da Bahia, Salvador-BA.

Fernando lazzetta, Universidade de São Paulo, São Paulo-SP. Jusamara Souza, Universidade Federal do Rio Grande do Sul, Porto Alegre-RS. Líliam Barros Cohen, Universidade Federal do Pará, Belém-PA. Luis Ricardo Queiroz, Universidade Federal da Paraíba, João Pessoa-PB. Paulo Castagna, Universidade Estadual Paulista Júlio de Mesquita Filho, São Paulo-SP. Paulo Murilo Guerreiro do Amaral, Universidade do Estado do Pará, Belém-PA. Robin M. Wright, University of Florida, Florida-EUA. Samuel Araújo, Universidade Federal do Rio de Janeiro, Rio de Janeiro-RJ. Sérgio Figueiredo, Universidade do Estado de Santa Catarina, Florianópolis-SC. Sonia Chada, Universidade Federal do Pará, Belém-PA. Sonia Ray, Universidade Federal de Goiás, Goiânia-GO.

\section{Cênicas}

Ana Flávia Mendes Sapucahy, Universidade Federal do Pará, Belém-PA. José Denis de Oliveira Bezerra, Universidade Federal do Pará, Belém-PA. Maria de Lourdes Rabetti, Universidade Federal do Estado do Rio de Janeiro, Rio de Janeiro-RJ. Cesário Augusto Pimentel de Alencar, Universidade Federal do Pará, Belém-PA.

Fernando Marques, Universidade de Brasília, Brasília-DF.

Maria Manuel Batista, Universidade do Minho e de Aveiro, Minho, PT.

Miguel Santa Brígida, Universidade Federal do Pará, Belém-PA.

Wladilene de Sousa Lima (Wlad Lima), Universidade Federal do Pará, Belém-PA. 


\section{Revisão:}

Keyla Sobral | Sávio Stoco

\section{Revisão Técnica:}

Keyla Sobral | Orlando Maneschy

\section{Programação Visual:}

Keyla Sobral | Breno Filo | Orlando Maneschy

\section{Diagramação:}

Breno Filo

\section{Capa:}

Marcela Cantuária, Fantasmas da Esperança (detalhe), 2018.

\section{Agradecimentos:}

Marcela Cantuária

Saulo Vinícius Almeida

Ruy Cézar Campos Figueiredo

Regilene Aparecida Sarzi-Ribeiro

João Víctor Kurohiji Bonani

Roseany Karimme Silva Fonseca

Luciana Brandão Carreira

Ana Luisa Lima

Sávio Stoco 


\section{SUMÁRIO}

Editorial

Portfólio

Marcela Cantuária

\section{ARTIGOS}

Comer a própria carne: o mito pessoal

como disparador do processo de criação cênica

Saulo Vinícius Almeida

Nas pegadas do carvão: performando uma paisagem

de contaminação ambiental

Ruy Cézar Campos Figueiredo

Experimentações artísticas na animação ocidental: Begone Dull Care

Regilene Aparecida Sarzi-Ribeiro

João Víctor Kurohiji Bonani

Caminhos marajoaras: o rio enquanto paisagem, poética e potência artística

Roseany Karimme Silva Fonseca

A Casa onde com ela estamos - escrita, torção e vertigem. (ou sobre quando o autobiográfico é ato biográfico)

Luciana Brandão Carreira

\section{ENSAIO}

Por uma curadoria operária

Ana Luisa Lima

Instruções aos autores de textos

Instructions for the authors 


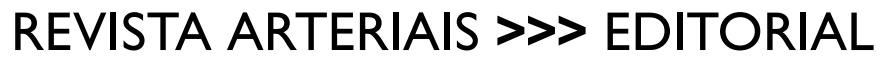

A Revista Arteriais chega a sua oitava edição com a contínua força que a fez emergir, a força da diversidade, dos pensamentos múltiplos e plurais, dos diálogos importantes e necessários sobre a arte. Traz escritas potentes, com diversas temáticas de reflexão, nos conduzindo sempre a um mundo possível de debates interdisciplinares possíveis.

Na seção Portfólio temos Marcela Cantuária, artista que ativa questões fundamentais para o mundo contemporâneo por meio da pintura. Suas obras propõem uma revisão de processos históricos violentos que assolaram a América Latina por meio das estruturas do poder colonialista. Forte, seu trabalho revisita as memórias das sociedades para lembrar daquilo que não podemos esquecer. Natureza, lutas feministas, povos ancestrais, violência institucionalizada confrontam com a percepção de que a vida é maior do que a violência impetrada por governos totalitários.

Na seção dos Artigos, temos: Comer a Própria Carne: o mito pessoal como disparador do processo de criação cênica, de Saulo Vinicius Almeida, onde o autor analisa o conceito de mito pessoal e seus desdobramentos em duas performances teatrais, Sebastian e Cura. Utiliza como base teórica os estudos do mito de Mircea Eliade, os estudos da psicologia profunda em sua relação com os conteúdos mitológicos de Carl Gustav Jung e seus continuadores e os escritos de Grotowski. No artigo Nas Pegadas do Carvão: performando uma paisagem de contaminação ambiental, de Ruy Cézar Campos Figueiredo, onde ele aborda poeticamente sobre a pesquisa/performance/videoinstalação Carvão Para Seus Olhos Tocarem em relação à paisagem, ressaltando estratégias para lidar com uma questão de contaminação ambiental que acontece nos fluxos de capital e materialidades entre o norte da Colômbia e o Ceará, no nordeste brasileiro. Já em Experimentações artísticas na animação ocidental: Begone Dull Care, dos autores Regilene Aparecida Sarzi-Ribeiro e João Victor Kurohiji Bonani, temos como tema a animação experimental e suas características, campo repleto de inovações técnicas e artísticas que é mantido à margem dos estudos sobre o cinema animado, com um olhar mais aprofundado sobre o curta animado "Begone Dull Care" de Norman McLaren e Evelyn Lambart. O artigo Caminhos marajoaras: o rio enquanto paisagem, poética e potência artística, de Roseany Karimme Silva Fonseca, é resultante dos estudos da autora na disciplina Cultura Amazônica: Uma Poética do Imaginário na Atualidade de Cultura-Mundo, do Programa de Pós-Graduação em Artes-PPGARTES/ UFPa que objetiva traçar um paralelo entre três eixos de referências para os rios marajoaras, sendo estes: a paisagem, a poética e a potência. Através da descrição e do reconhecimento dos rios nos referidos eixos, propõe-se então o encontro destes afluentes com o percurso da artista-pesquisadora de Artes neste lócus, definindo-o como espaço de identificações e criação artística. $O$ artigo $A$ casa onde com ela estamos - escrita, torção e vertigem (ou sobre quando o autobiográfico é ato biográfico), de Luciana Brandão Carreira, aborda uma questão importante da escrita que cumpre funções diferentes, para diferentes sujeitos, em diferentes momentos. Reflete sobre a escritora Clarice Lispector, que fez de seu exercício de escriba o próprio manejo implicado no refazer de seu corpo, enlaçando-se, através do ato de escrever, pulsionalmente a uma língua.

$\mathrm{Na}$ Seção Ensaios, temos a curadora Ana Luisa Lima, com Por uma curadoria operária, onde vem atentamente analisando o momento atual que o País se encontra, e, seu contexto no campo da arte e seus desdobramentos.

A Revista Arteriais reitera seu compromisso com as práticas democráticas de livre expressão e de pensamento, fazendo um esforço conjunto para a difusão do conhecimento e dos estudos sobre as artes, partindo de uma Universidade Pública e repercutindo para o mundo, de forma cooperada e dialógica, sempre entendendo da sua importância em ser um espaço de liberdade.

Os editores 


\section{PORTFOLIO $\gg>$ MARCELA CANTUÁRIA}

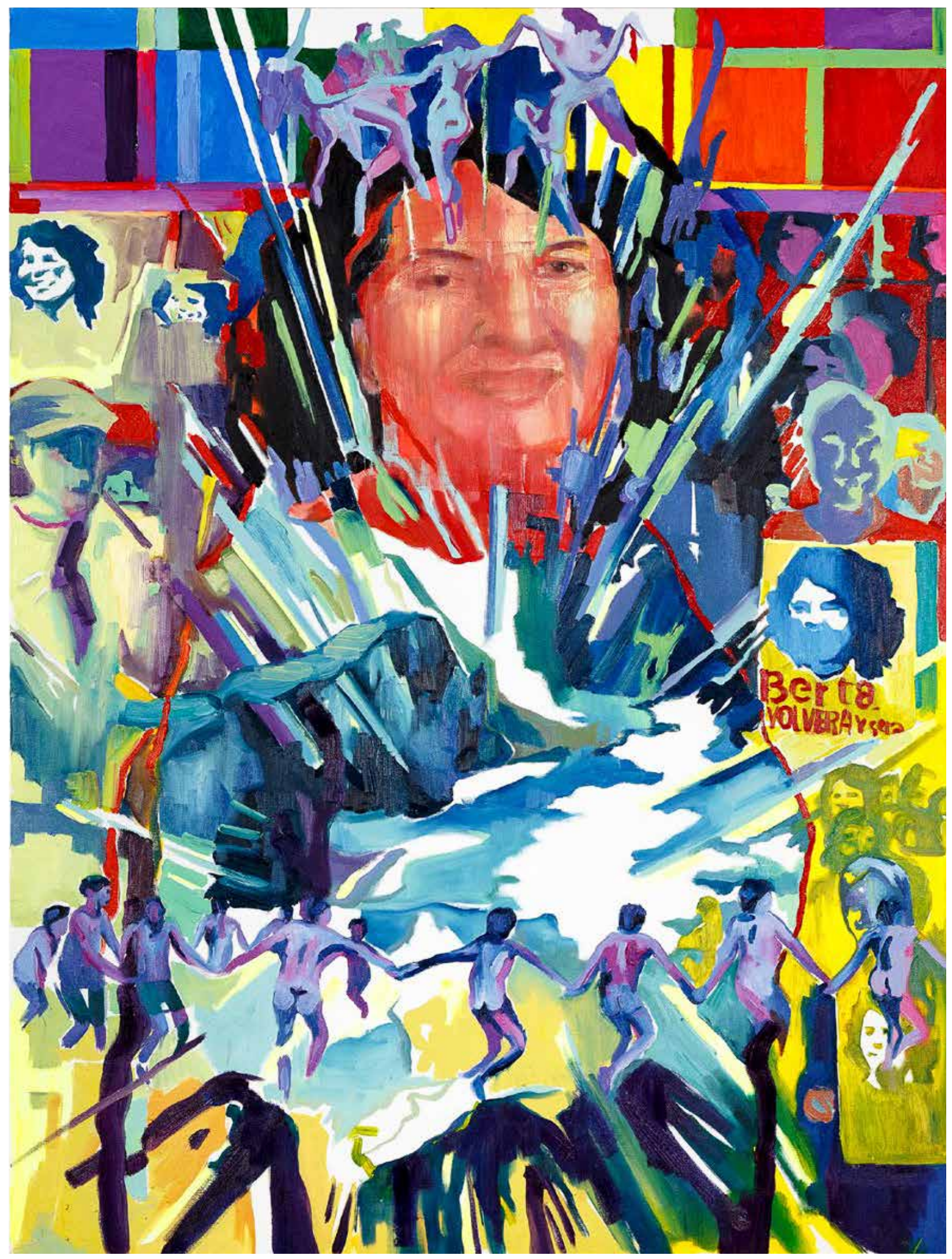




\section{PINTURA REVISIONISTA, NARRATIVAS CONTRA O SILÊNCIO}

Marcela Cantuária estabelece um caminho no qual a pintura é a matriz para a expansão dos pensamentos sobre o mundo ao seu redor. De apropriações de imagens da história, do universo da política e de como a sociedade faz circular acontecimentos, a artista articula tanto as referências advindas da mídia, quanto os documentos de acervo e estudos acadêmicos que terminam por alimentar suas pesquisas que se realizam em suas telas.

Cantuária olha as lutas sociais, os embates históricos de classes, o racismo, o protagonismo feminino, as percepções acerca das forças que operam nas estruturas sociais e ativa signos da cultura e do inconsciente para construir um projeto artístico que desordena estruturas simbólicas de poder.

Povos originários, mães da Praça de Maio, militantes, guerrilheiras, animais e natureza figuram em suas obras disparando criticidade sobre os processos violentos que se estabelecem na América Latina. Catástrofe, racismo estrutural, violências perpetradas pelo capitalismo neoliberal. A despeito de tantas evidências que revelam o colonialismo presente nas raízes, e sangram o povo, sua obra nos conduz a um desejo de reparação, dívida histórica dos processos de exploração, na busca do Bem Viver, das formas de vida em harmonia com a natureza. Seus trabalhos intencionam ativar um dispositivo de conteúdo que denomina de "anti-aminéico", como mecanismo de revisão histórica contra os múltiplos processos de apagamento dos mais vulneráveis pela história oficial e pelos regimes totalitários.

Além dos conteúdos densos, a pintura de Marcela Cantuária traz na elaboração das imagens um repertório visual farto e complexo, uma colagem de temporalidades e referências imagéticas, por vezes anacrônicas, que projetam um inconsciente coletivo, materializadas em cores vibrantes e contrastantes. Nada é gratuito na construção simbólica da artista. Política, supra-partidária, Cantuária enuncia sobre as políticas dos corpos, da violência imposta ao cidadão no dia a dia das cidades e do campo. Sua obra testemunha a violência que o homem impõe a si mesmo; todavia nos convida, ao fim de tudo, e de forma crítica, áspera e bela, a ter esperança.

Orlando Maneschy 


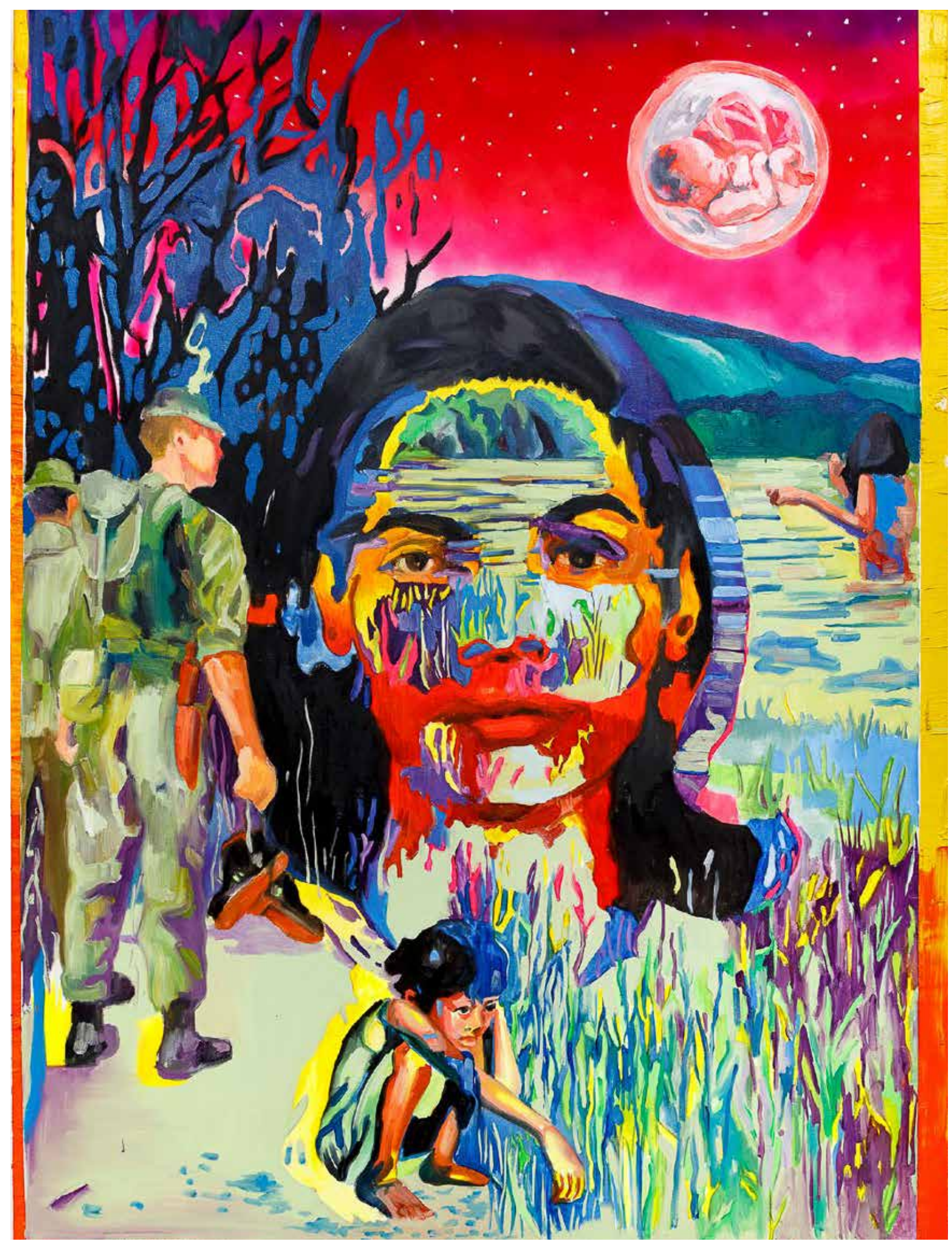




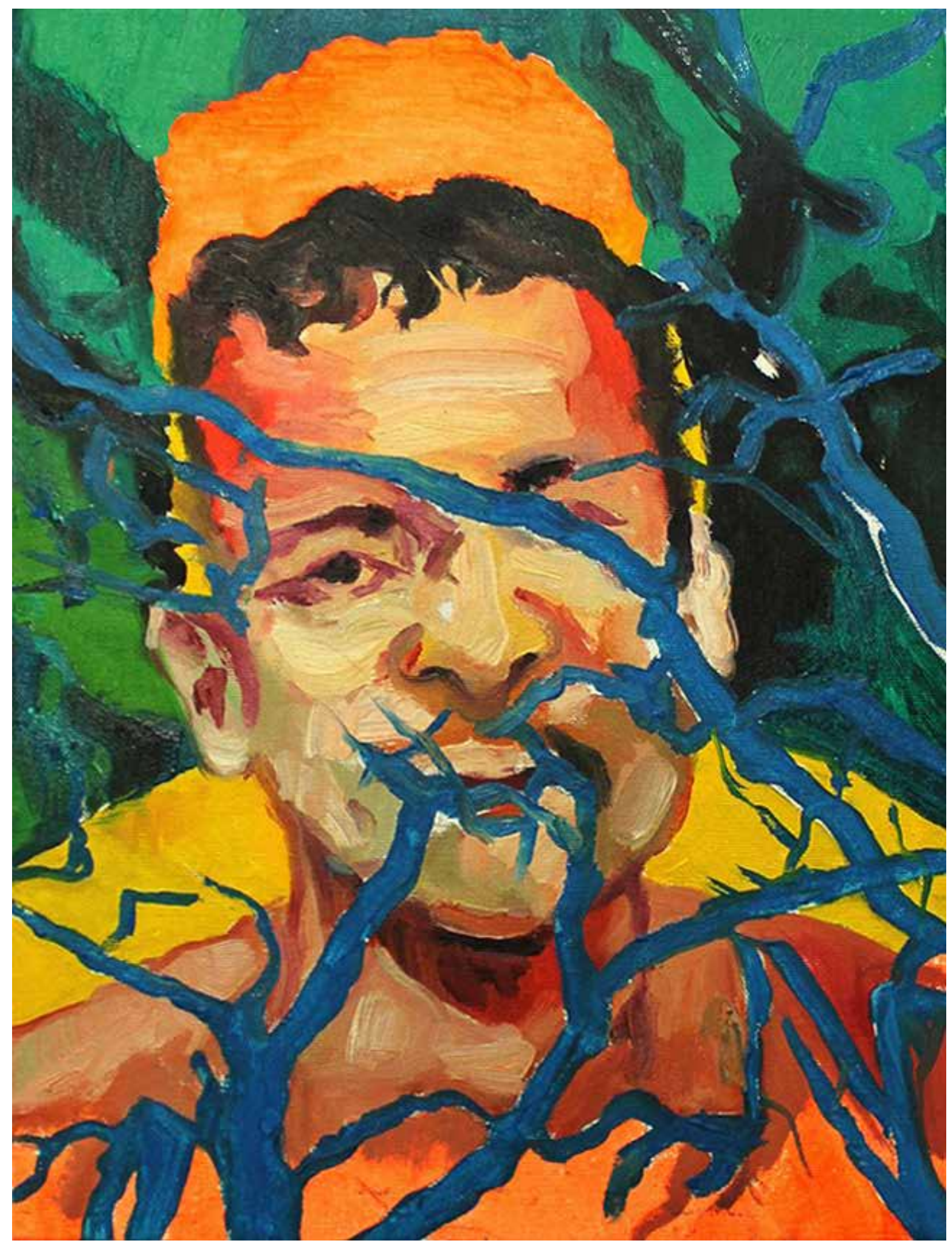

Alexandre, da série Biografia da Água e da Terra Óleo e acrílica sobre tela, 40 × 30cm 


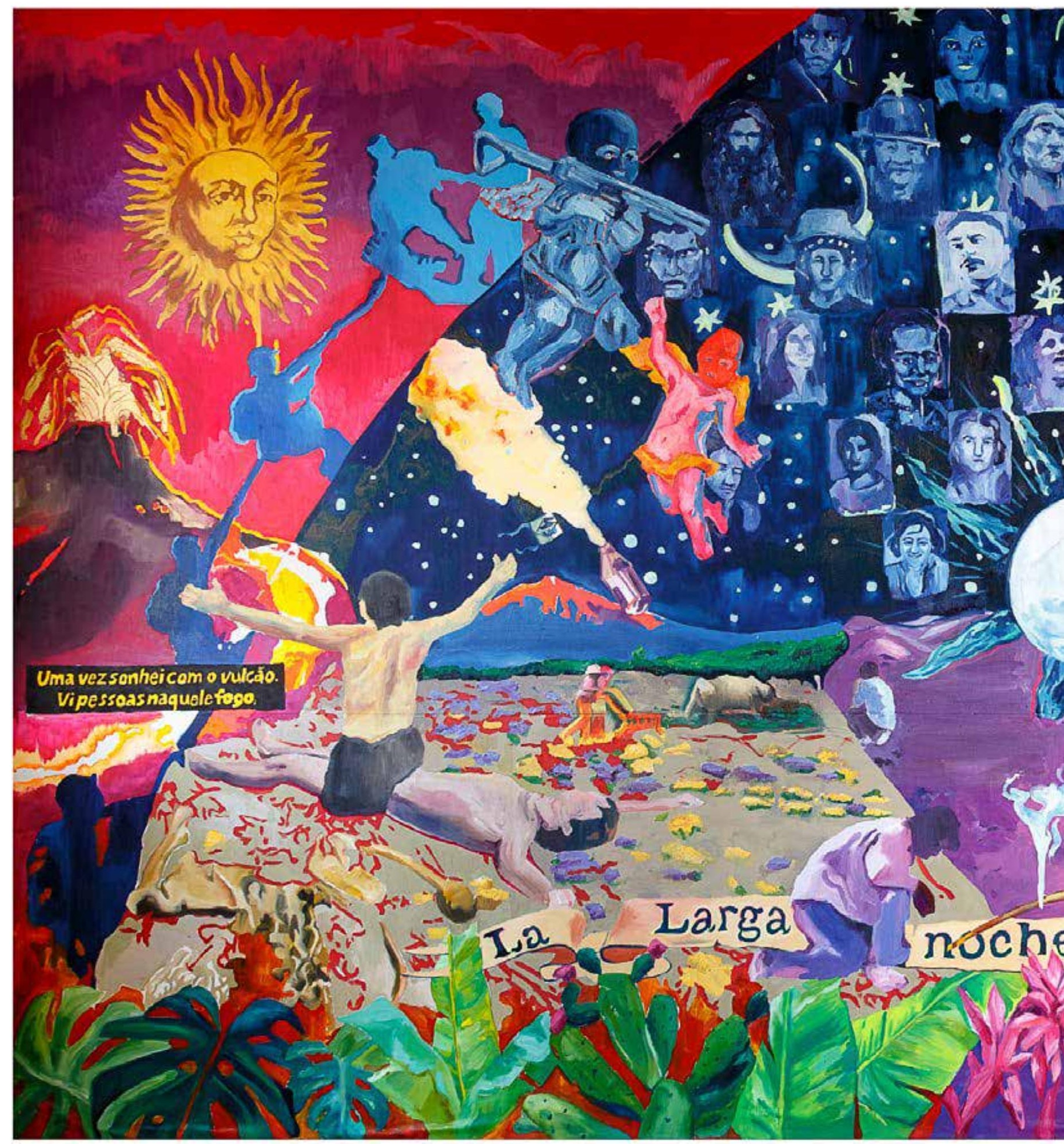

La larga noche de los 500 años, Óleo, acrílica e spray sobre tela, 270 x 500cm 2019 


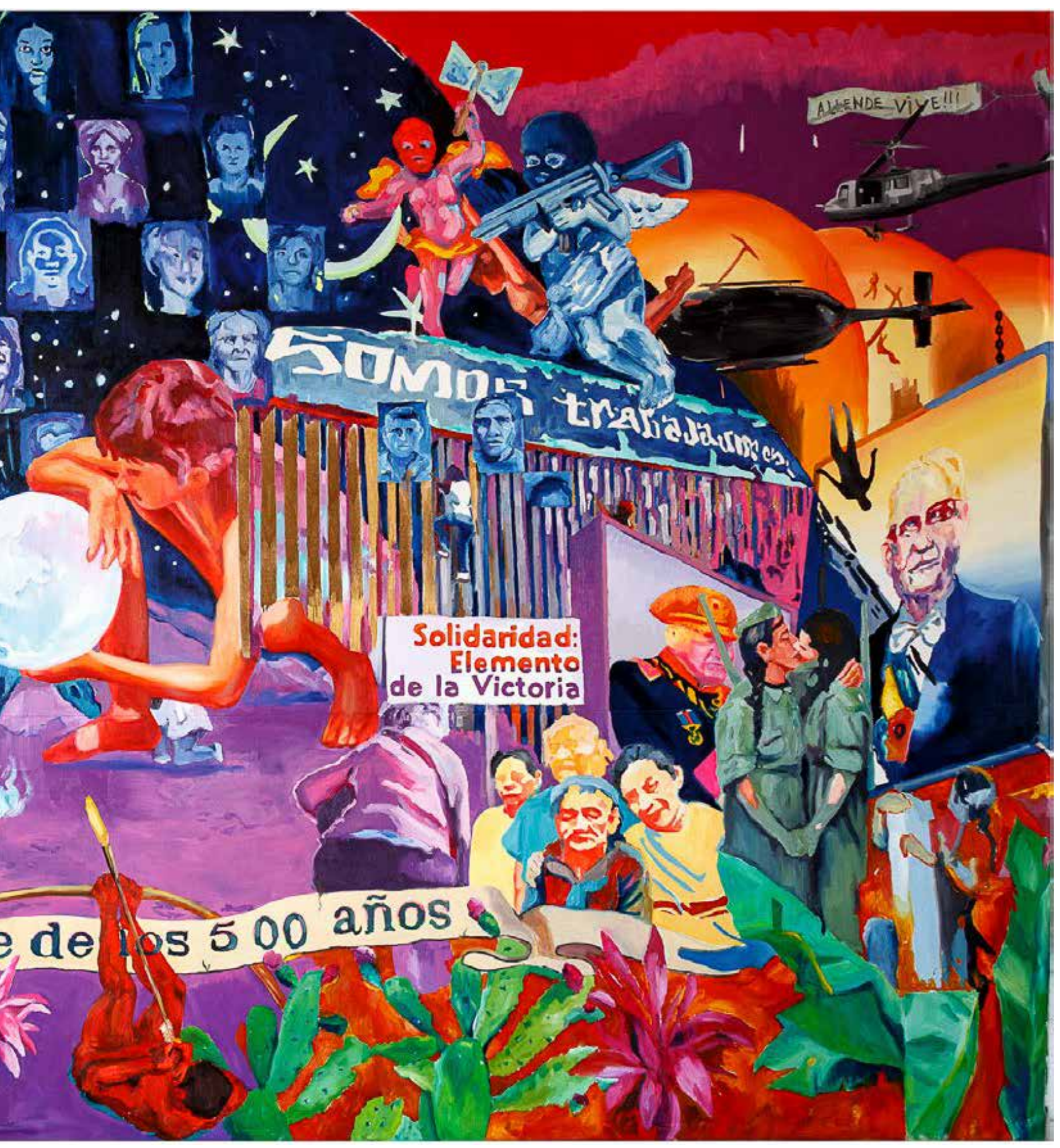




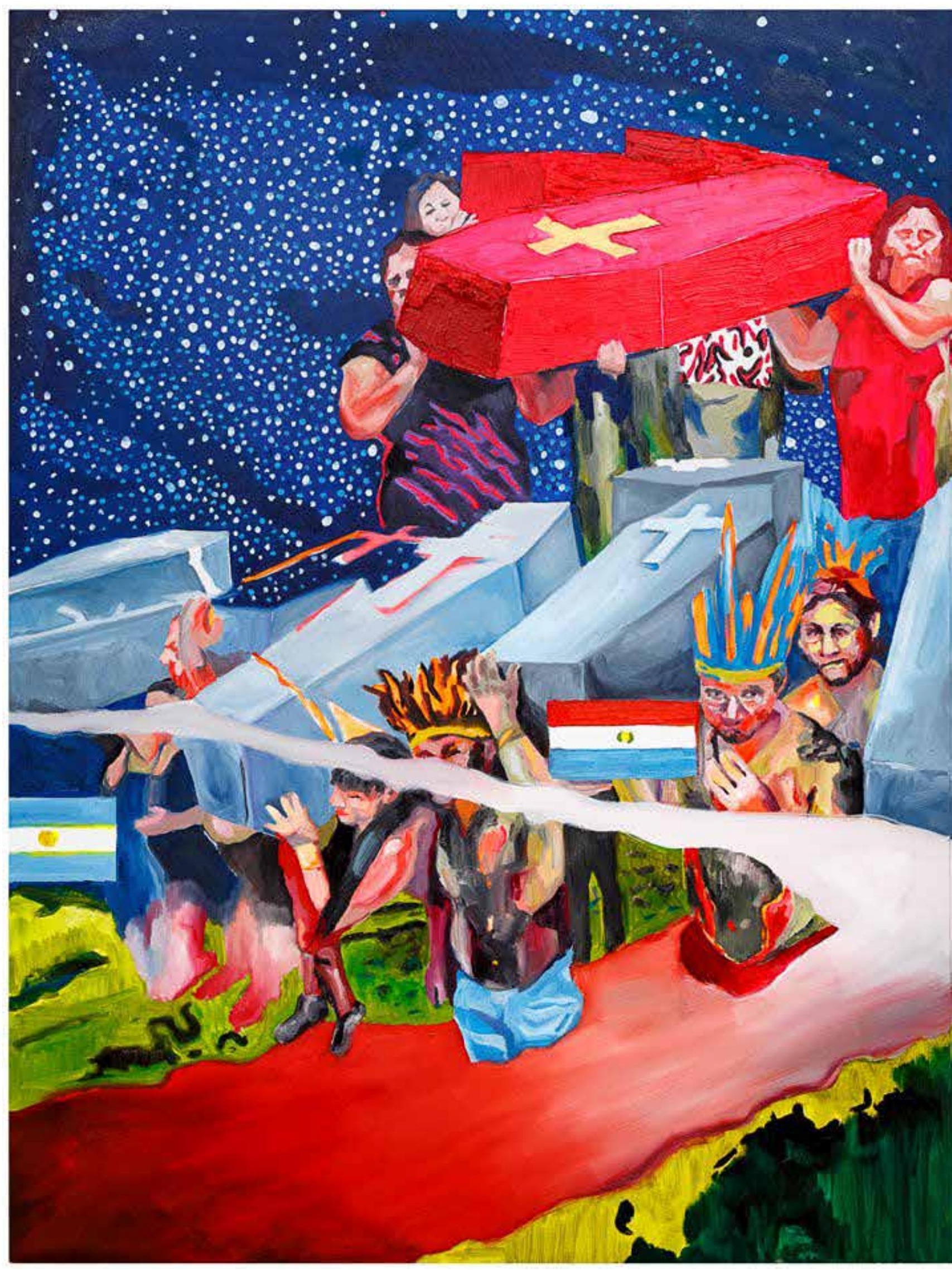

Procissão no Sul Global, Óleo e encáustica sobre tela, 160 x 240cm (díptico) 2019 


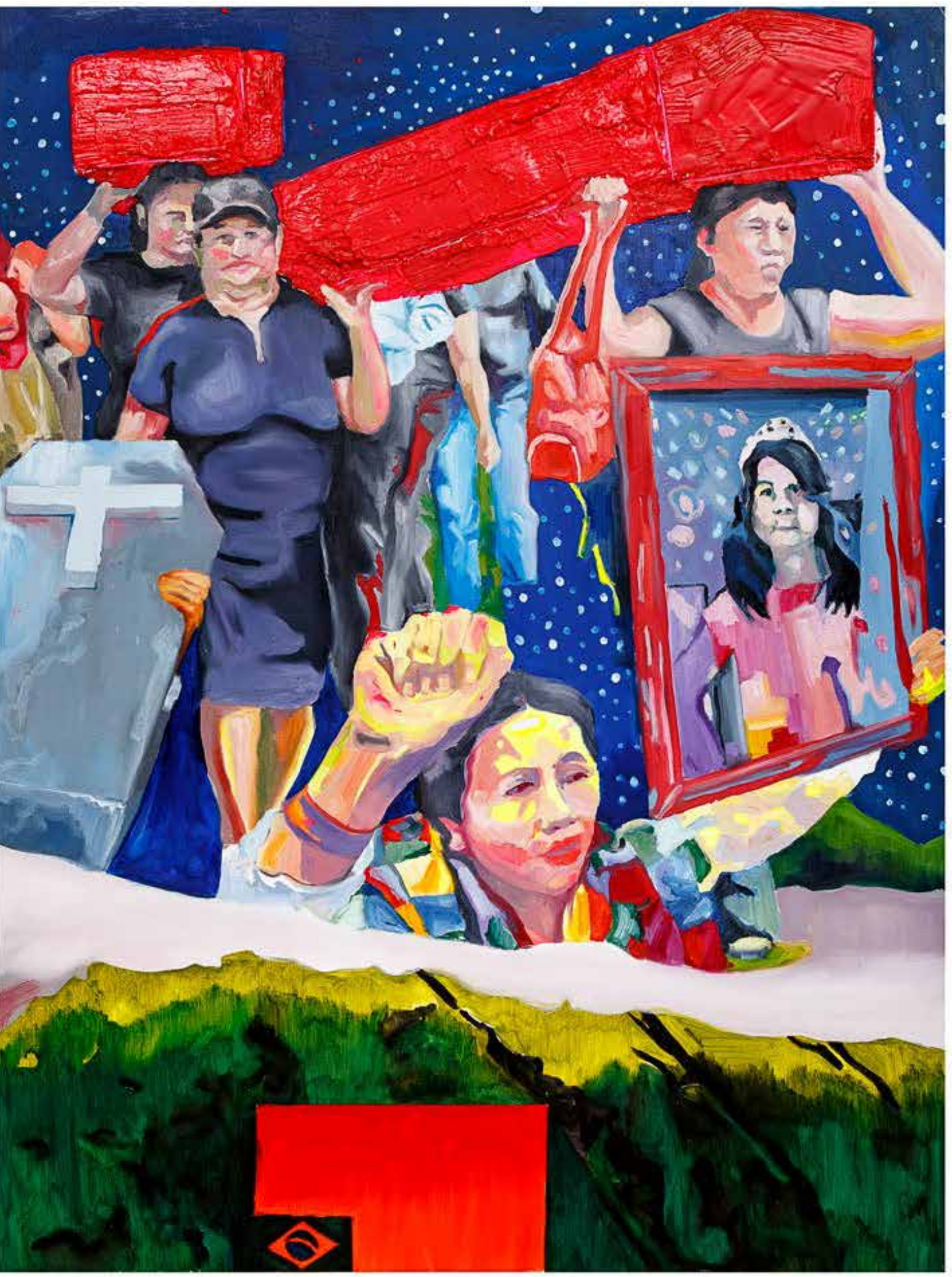




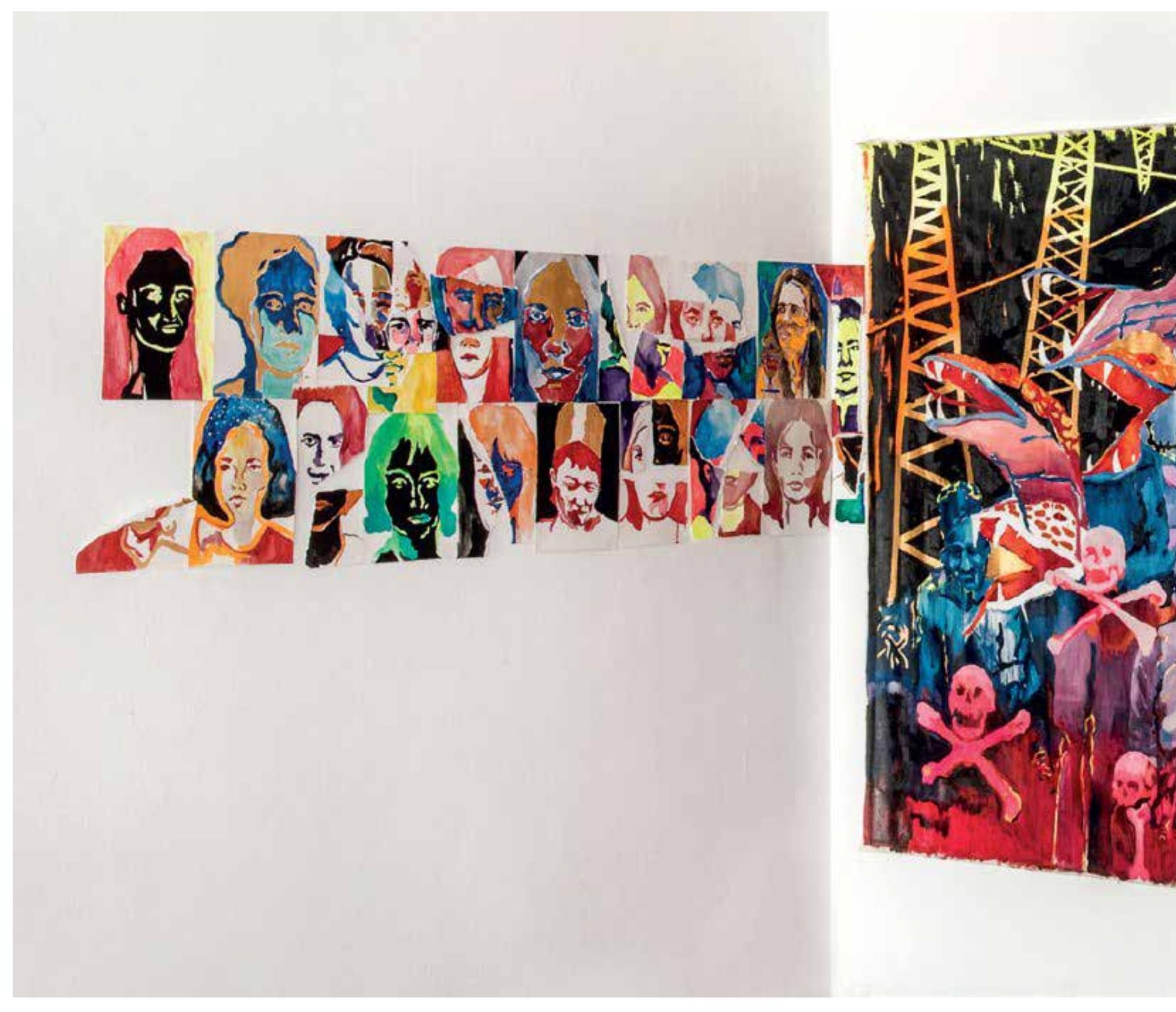

O Sul Nunca Morre, da série Futuro do Pretérito

Óleo, acrílica, spray sobre tela, 30 aquarelas sobre papel, dimensões variáveis 2019 

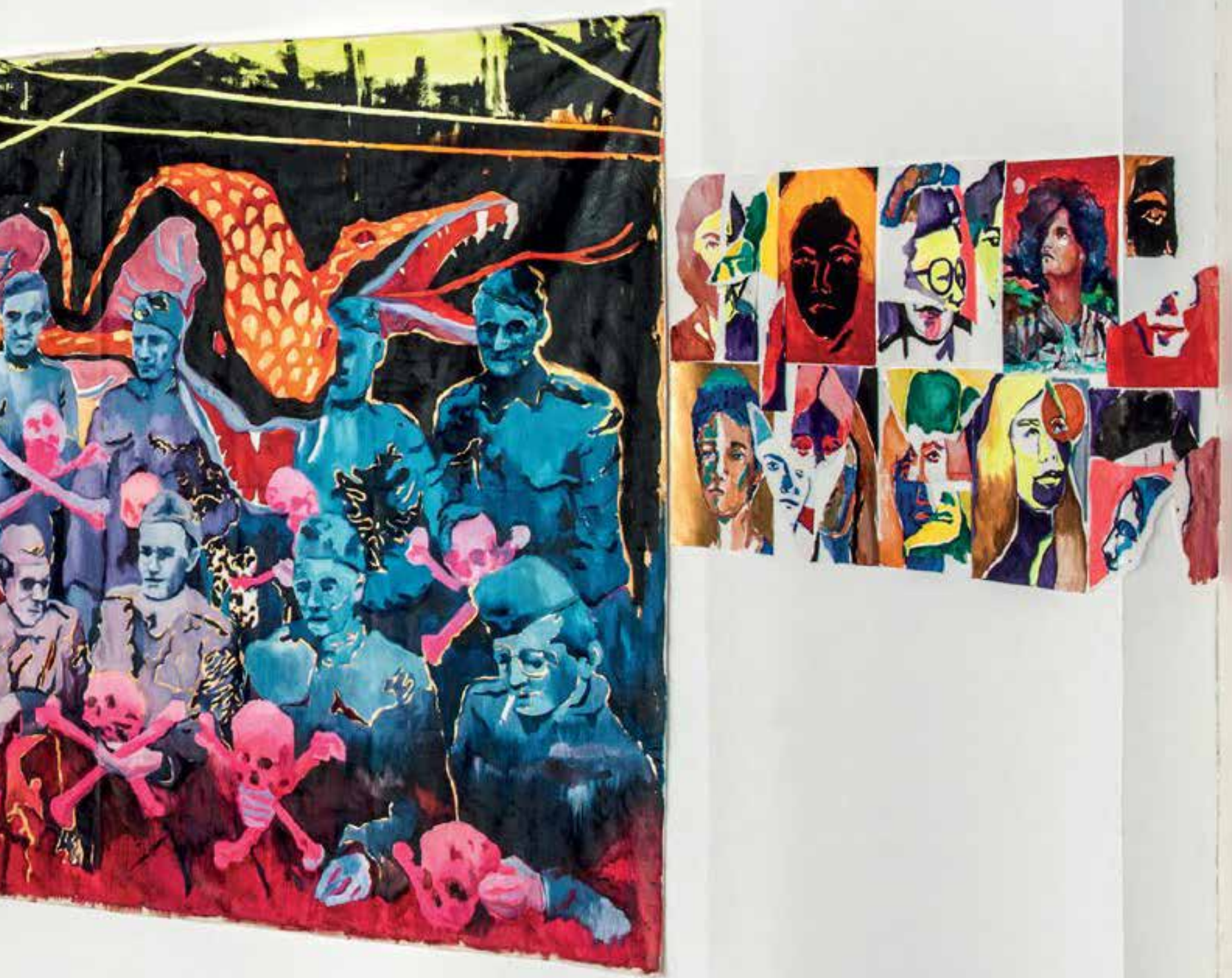


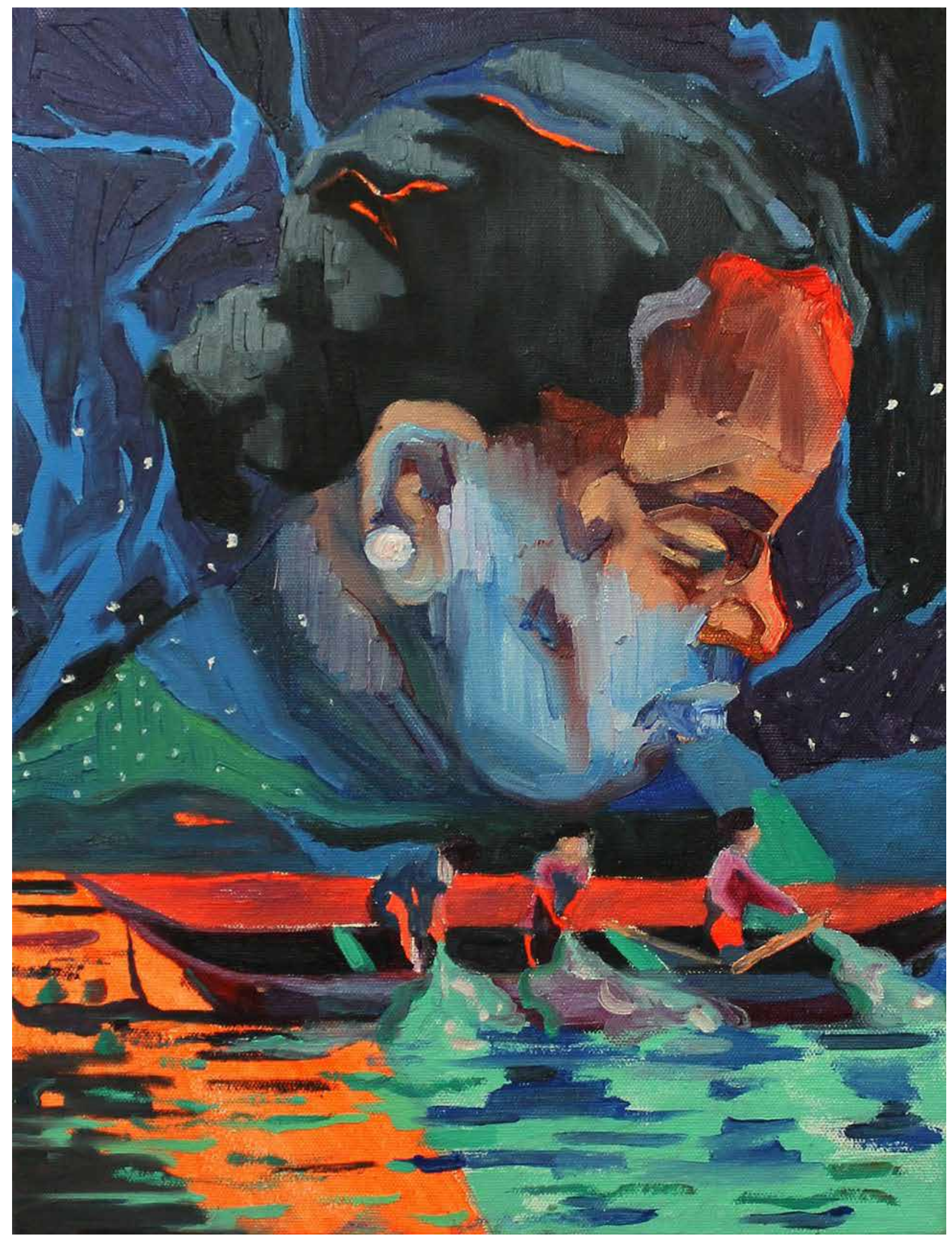

Conceição com Brinco de Pérola, da série Biografia da Água e da Terra Óleo sobre tela, $40 \times 30 \mathrm{~cm}$ 2019 


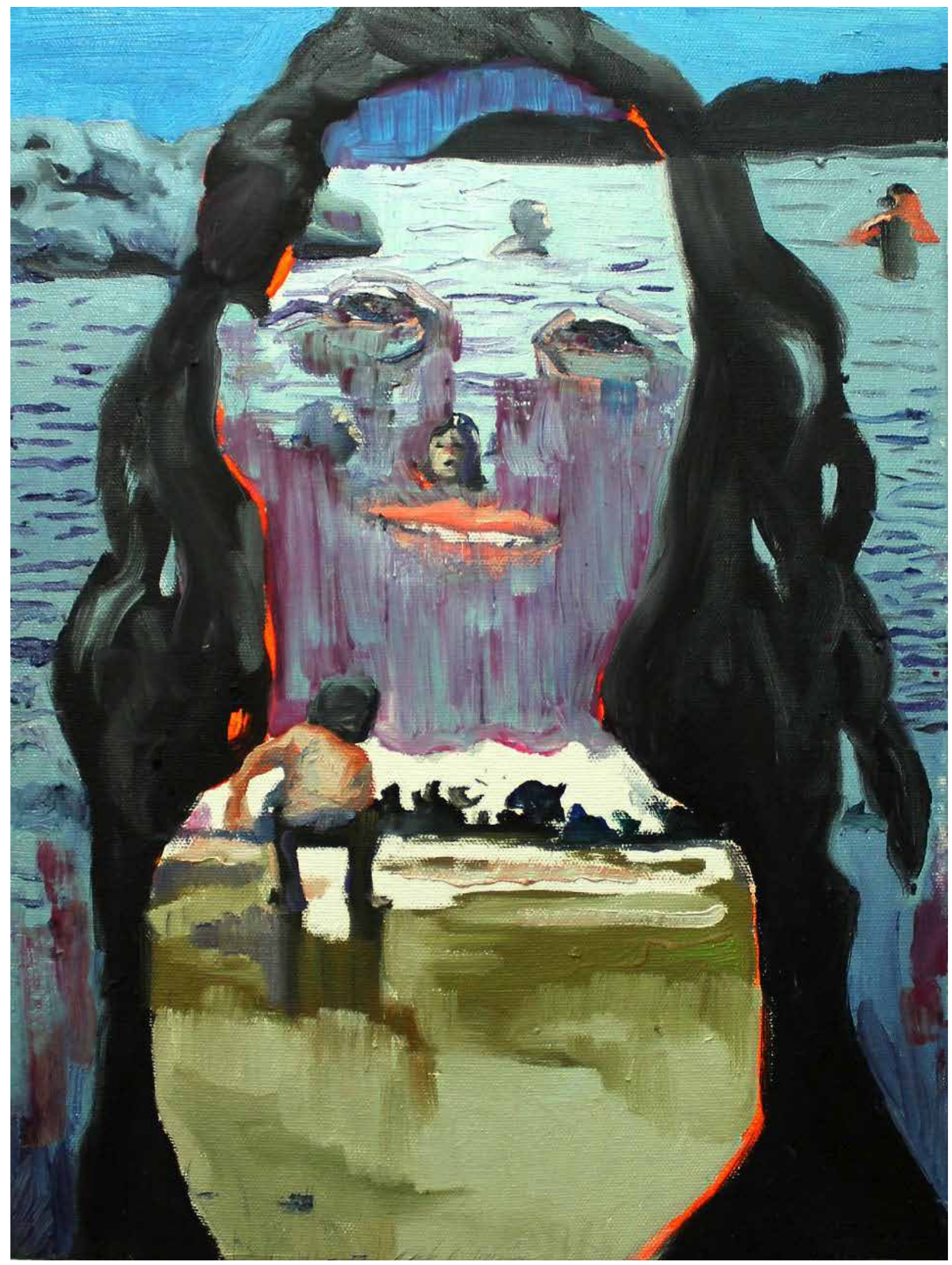

Clotildes, da série Biografia da Água e da Terra Óleo e acrílica sobre tela, 40 × 30cm 


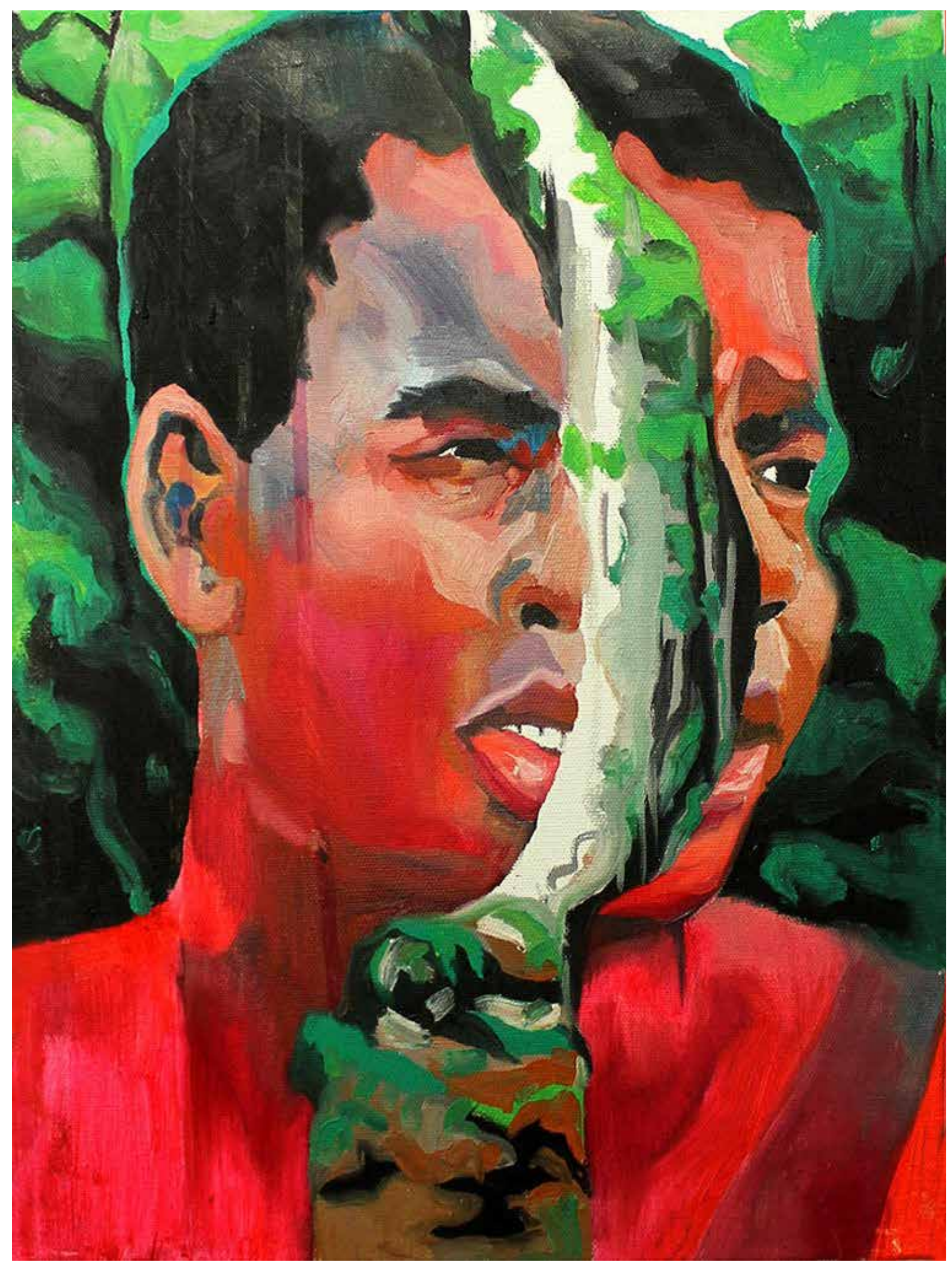

Jefferson, da série Biografia da Água e da Terra Óleo sobre tela, $40 \times 30 \mathrm{~cm}$

2019 


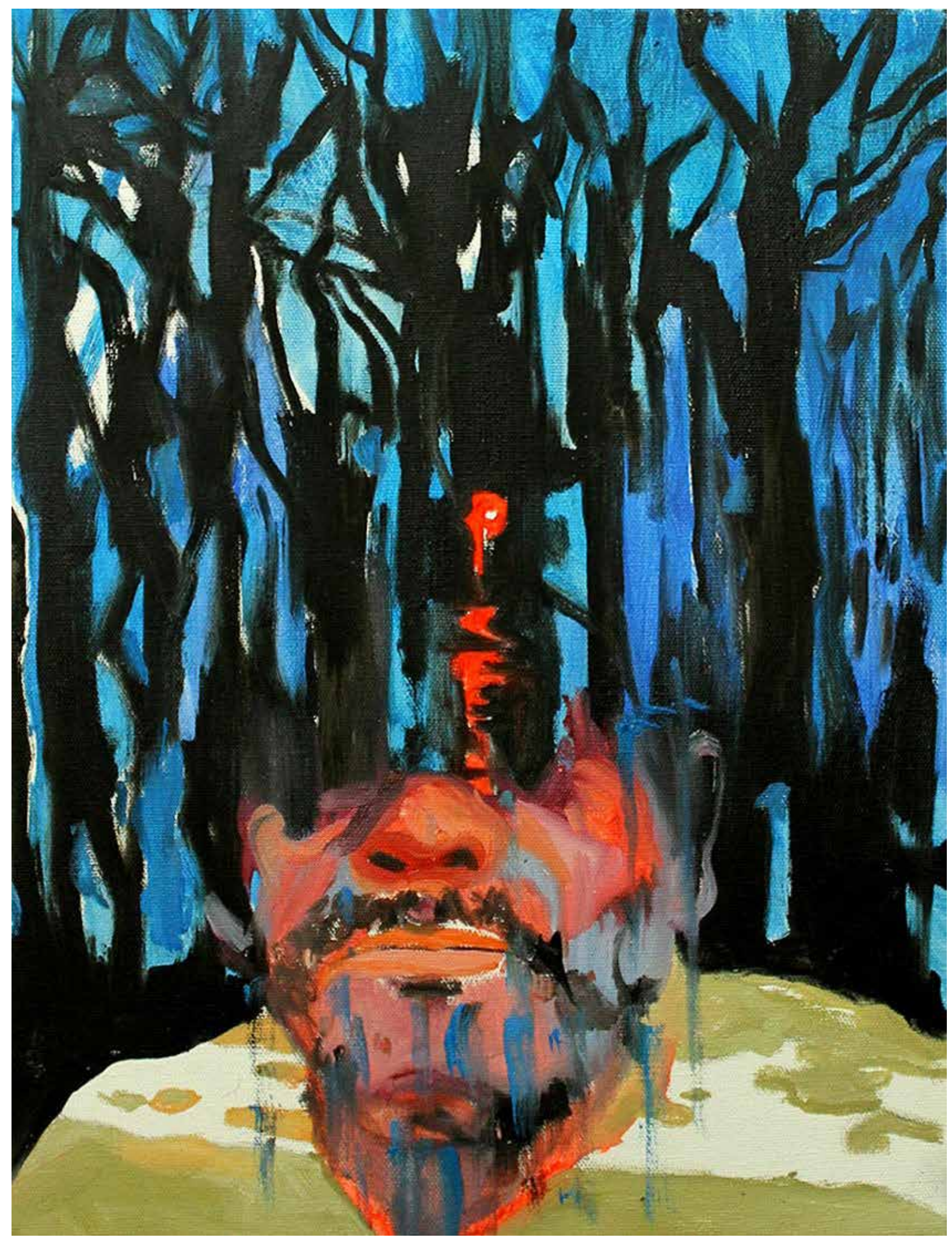

Binho, da série Biografia da Água e da Terra Óleo sobre tela, $40 \times 30 \mathrm{~cm}$ 


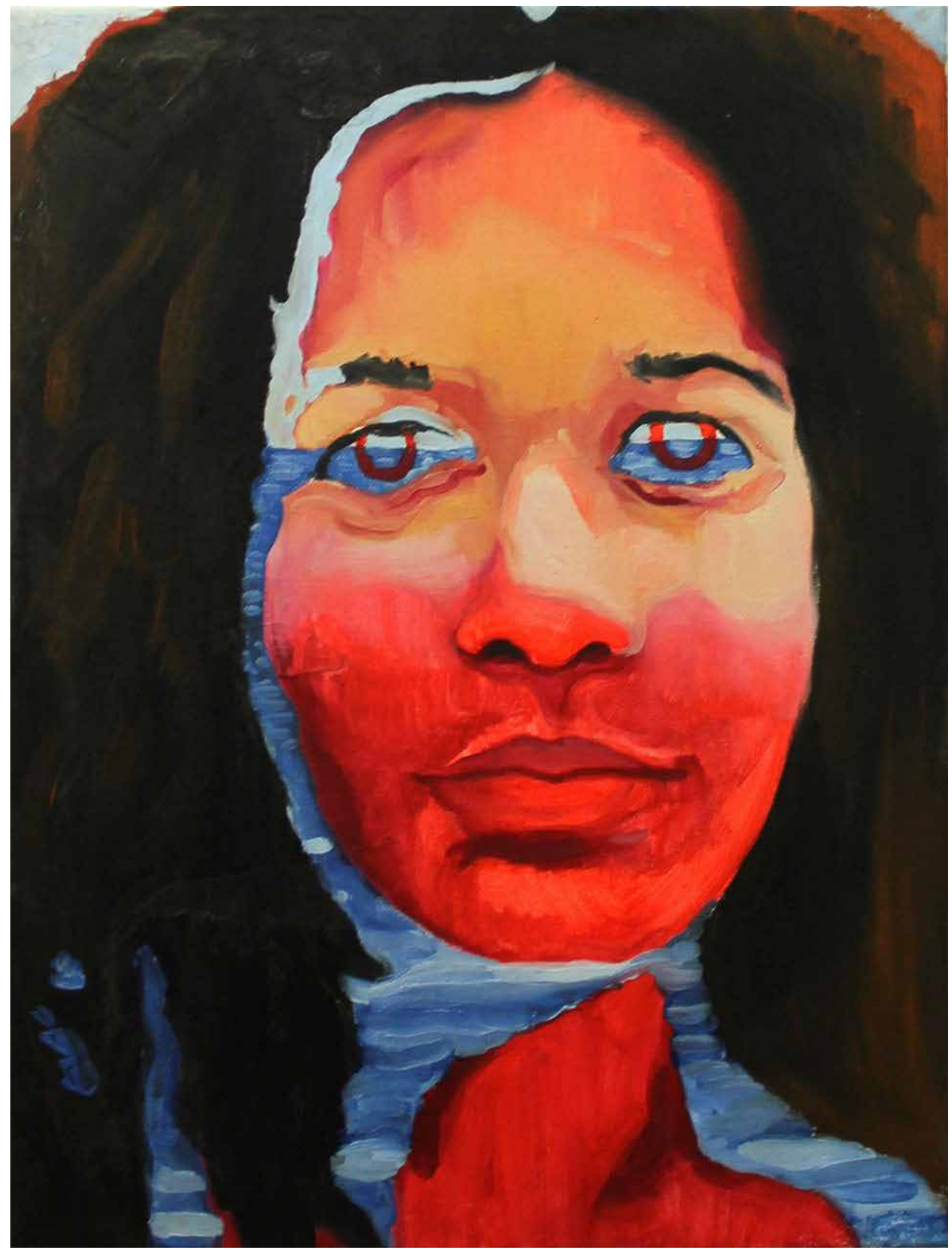

Paola, da série Biografia da Água e da Terra Óleo sobre tela, $40 \times 30 \mathrm{~cm}$ 2019 


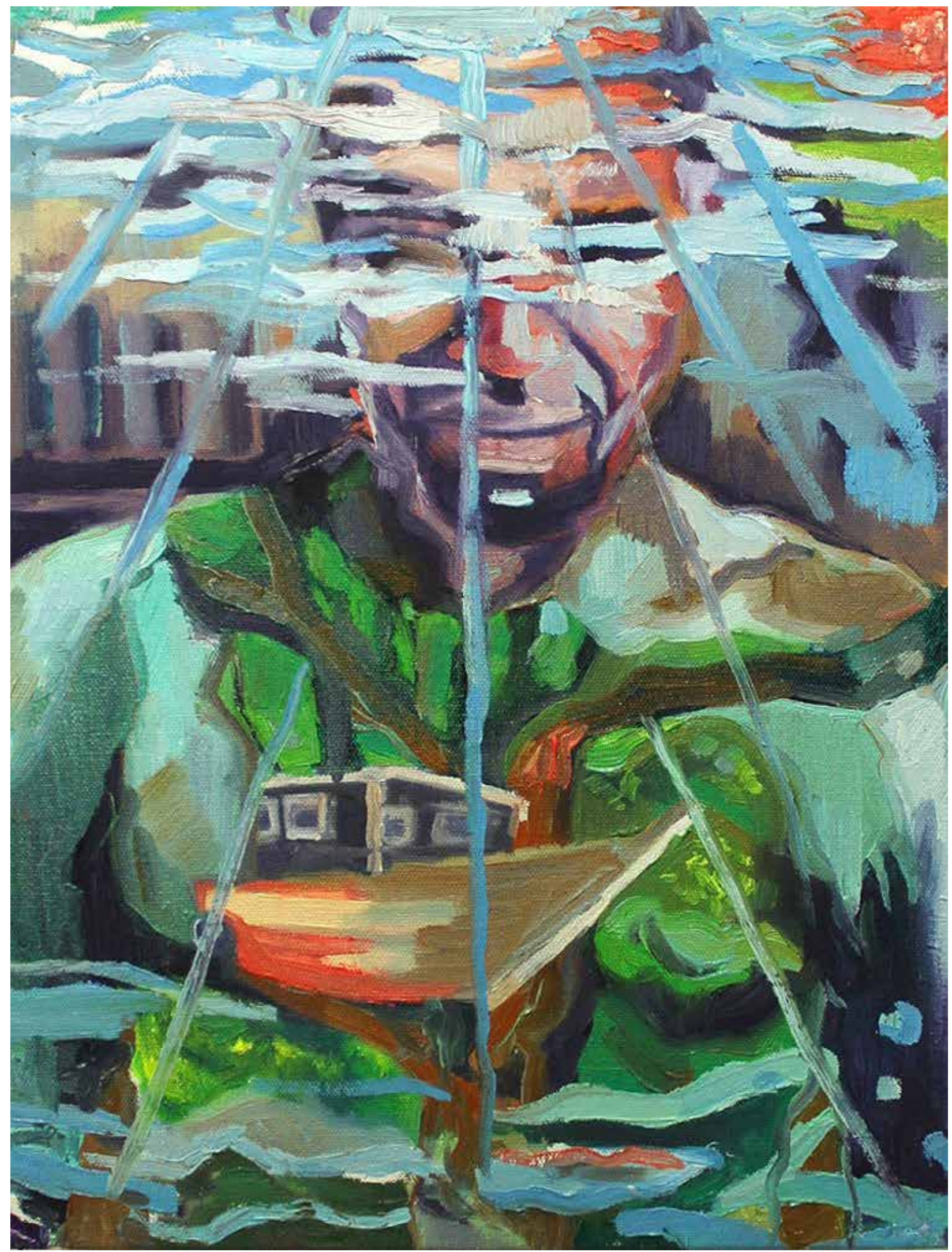

Dalton, da série Biografia da Áqua e da Terra Óleo sobre tela, $40 \times 30 \mathrm{~cm}$ 

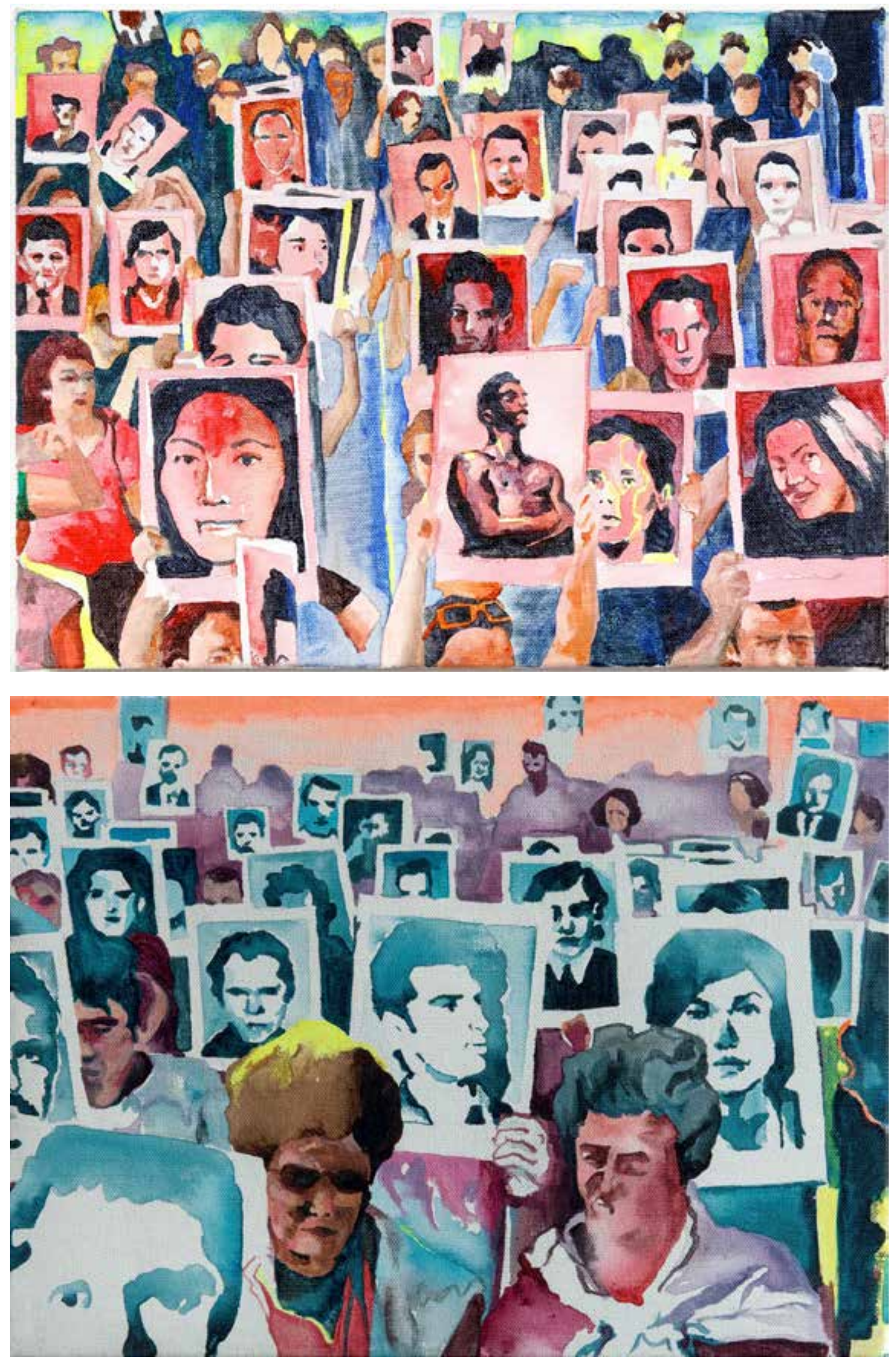

Acima: Comissão da Verdade 1, da série Futuro do Pretérito Acrílica sobre tela, $30 \times 40 \mathrm{~cm}$

2018

Abaixo: Comissão da Verdade 2, da série Futuro do Pretérito Acrílica sobre tela, $30 \times 40 \mathrm{~cm}$ 2018 


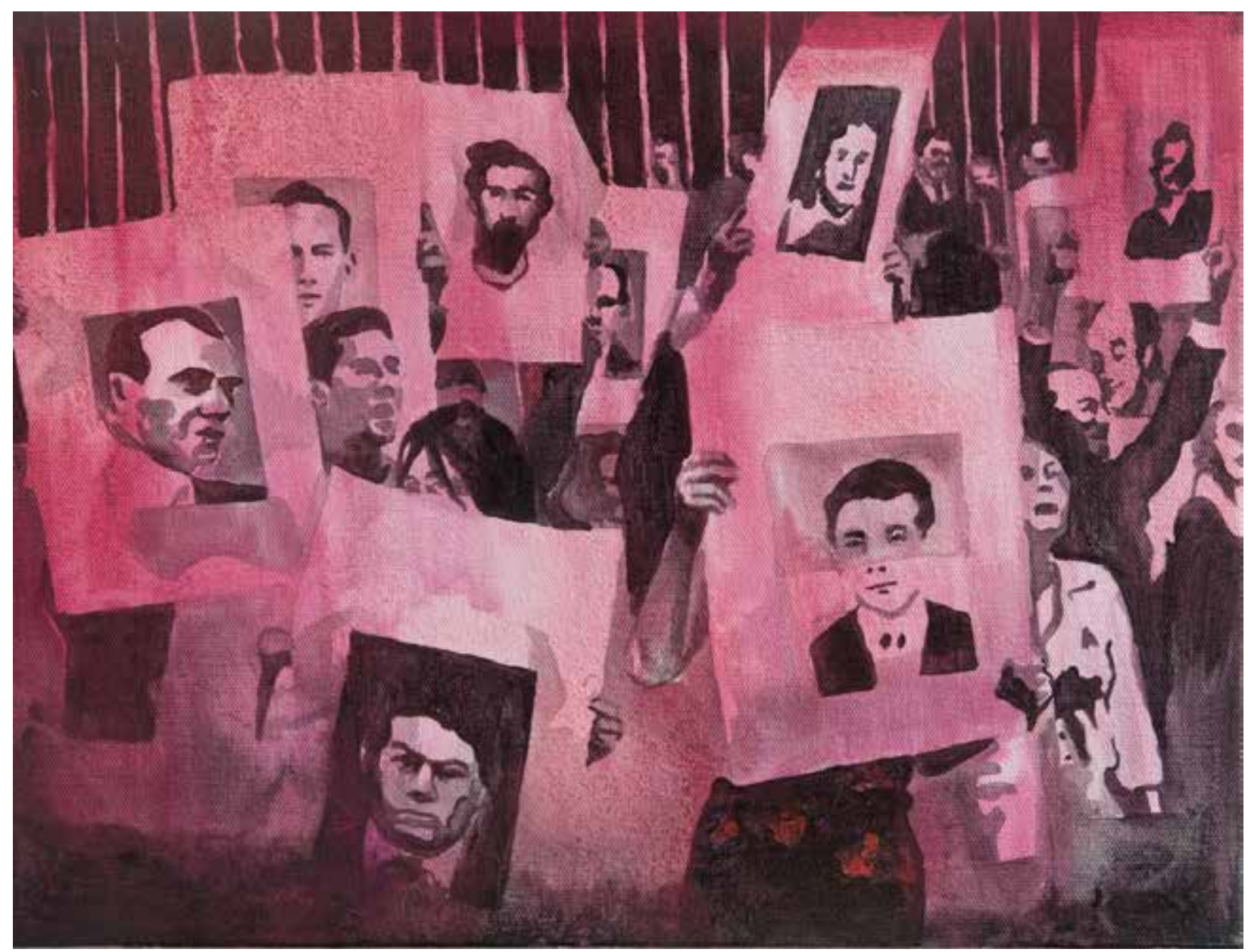




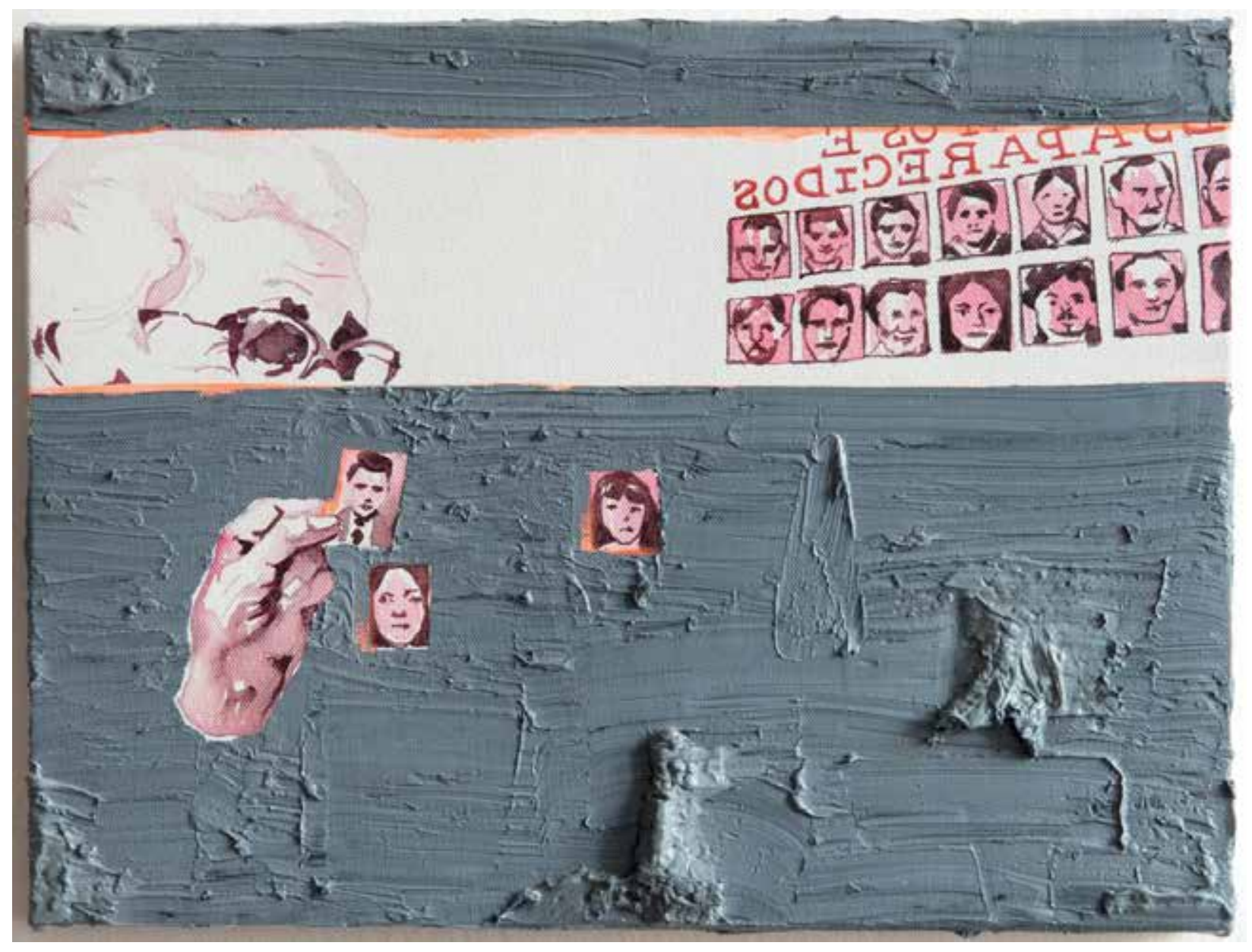

Porão Ecoa, da série Futuro do Pretérito Óleo e acrílica sobre tela, 30 x $40 \mathrm{~cm}$ 2018 


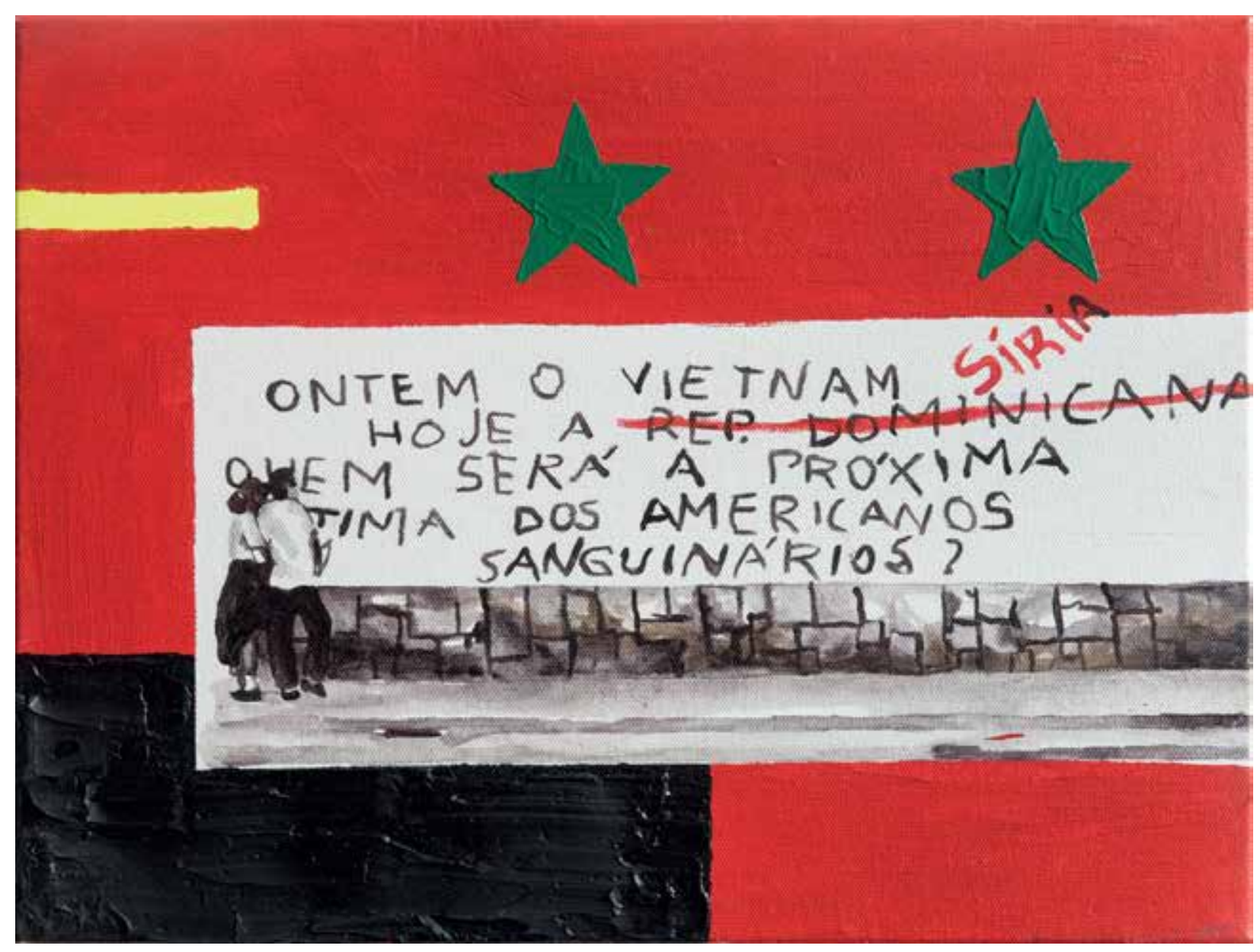




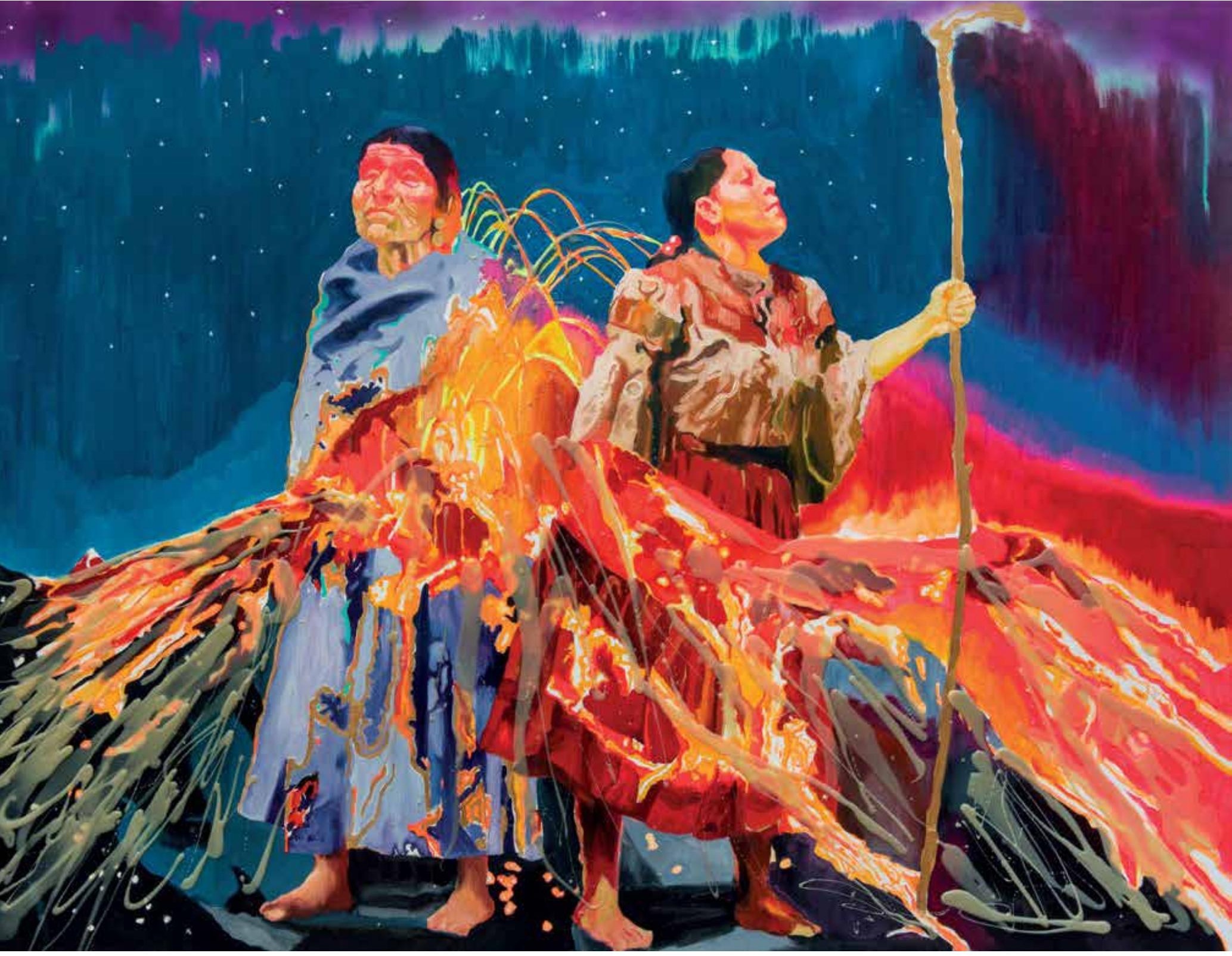

Filhas do Vulcão | Mamá Dolores y Mamá Trânsito, da série Mátria Livre Encaústica, óleo, acrílica e spray sobre tela, 150 × $200 \mathrm{~cm}$ 2019 


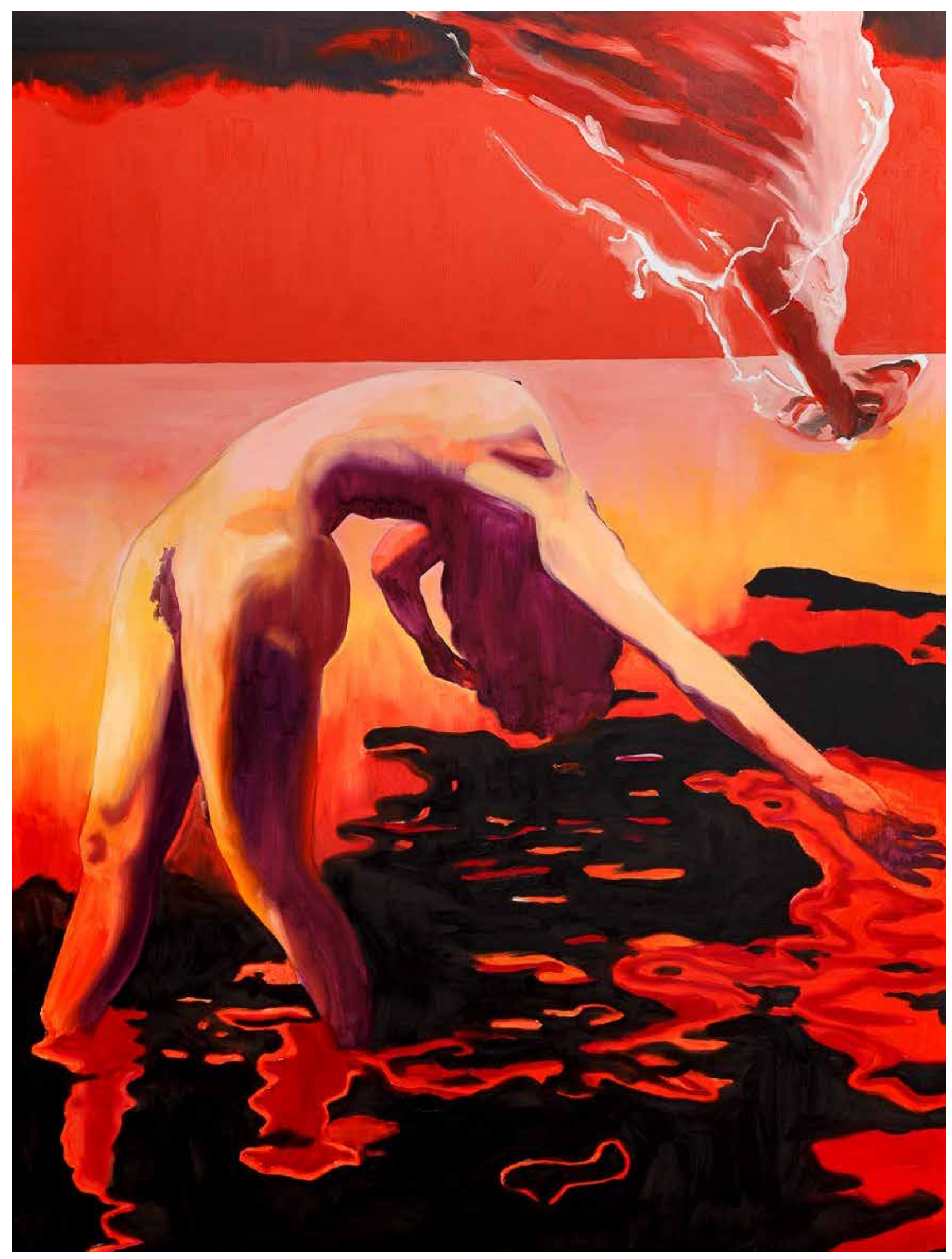




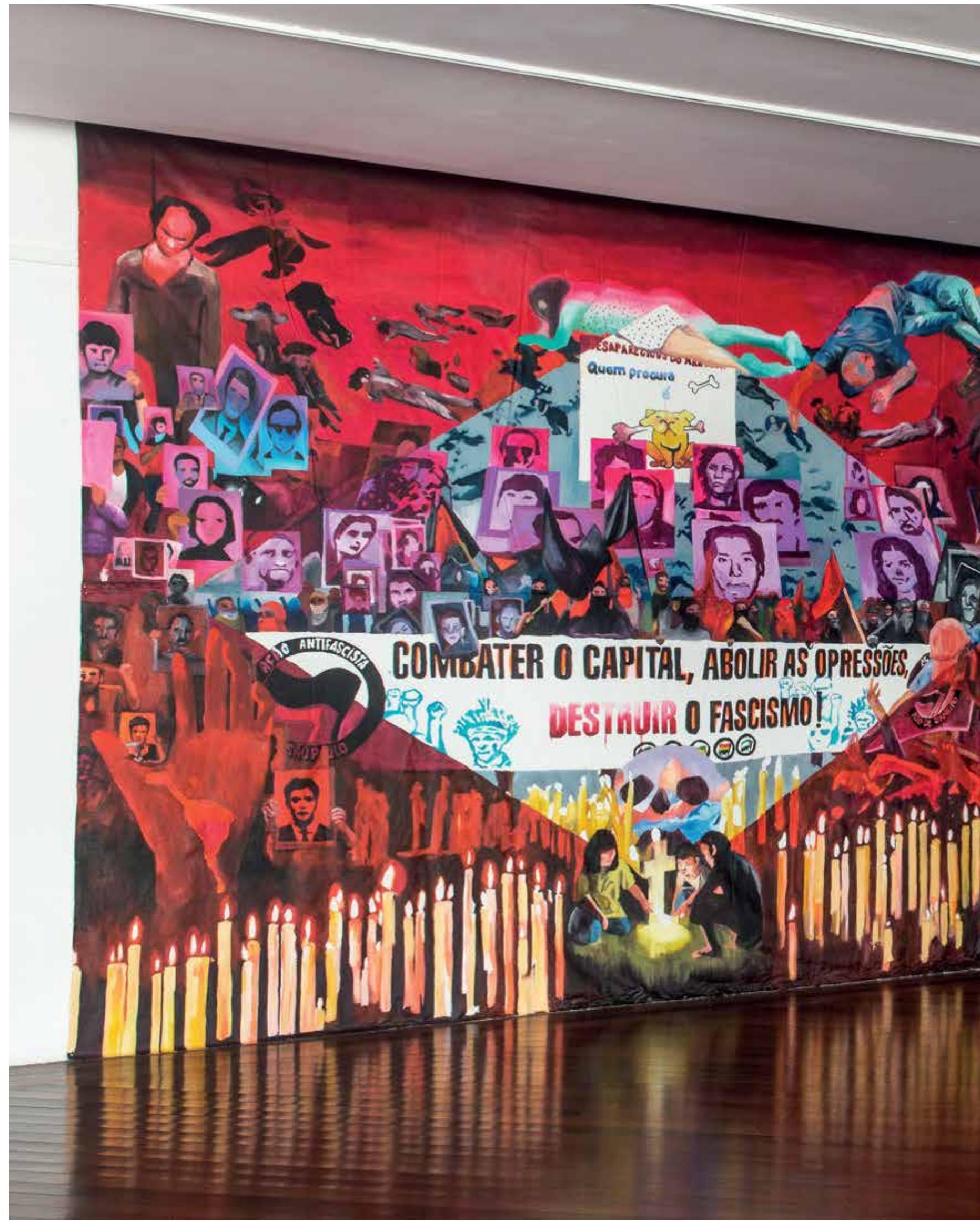

Fantasmas da Esperança, vista da exposição Sutur|ar Libert|ar, Centro Municipal de Arte Hélio Oiticica Óleo e acrílica sobre compensado, 320 x 450cm (retângulo) e $100 \mathrm{~cm}$ (círculo) 2018 


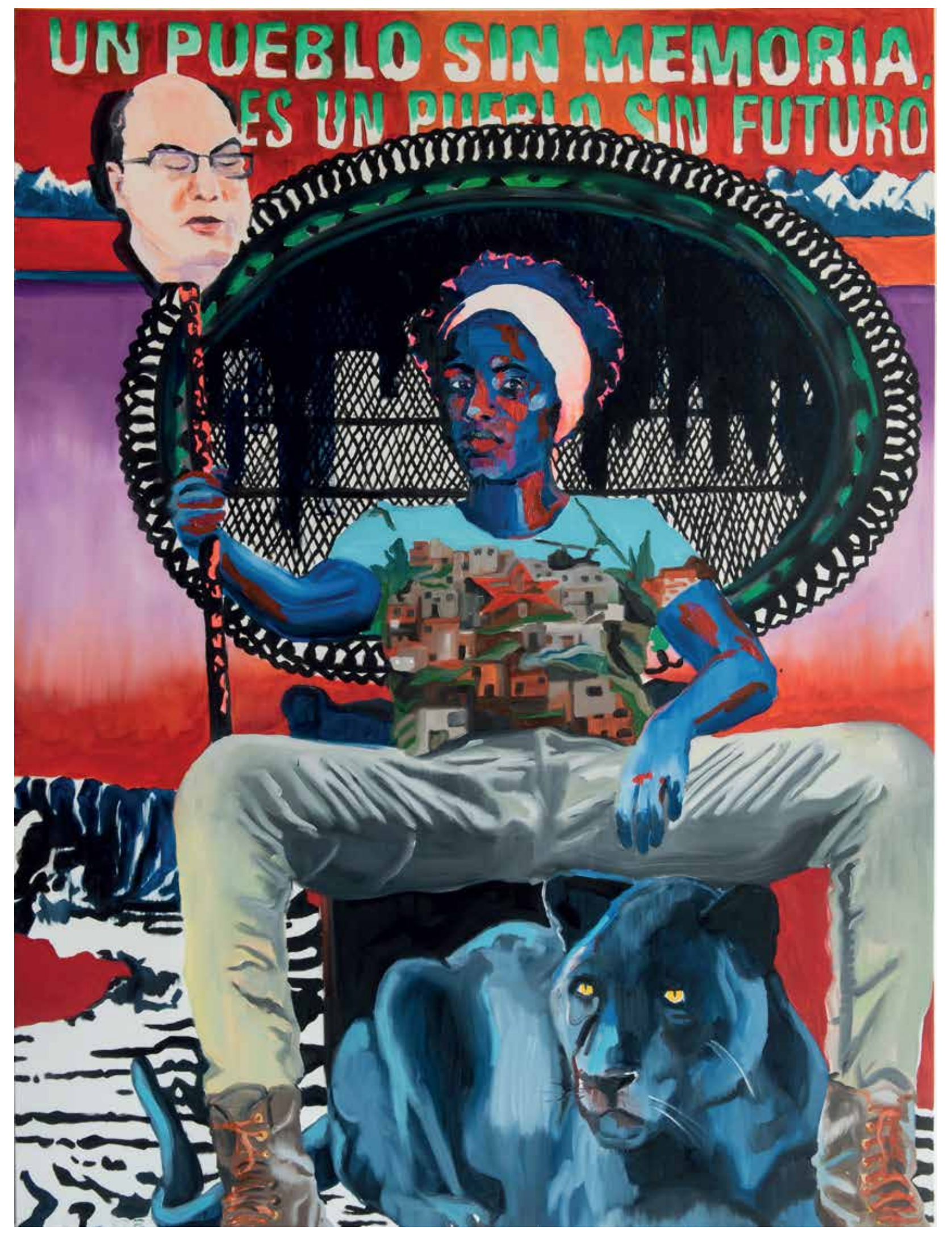

Voltarei e Serei Milhões

Óleo e acrílica sobre tela, 200 x $150 \mathrm{~cm}$

2018 

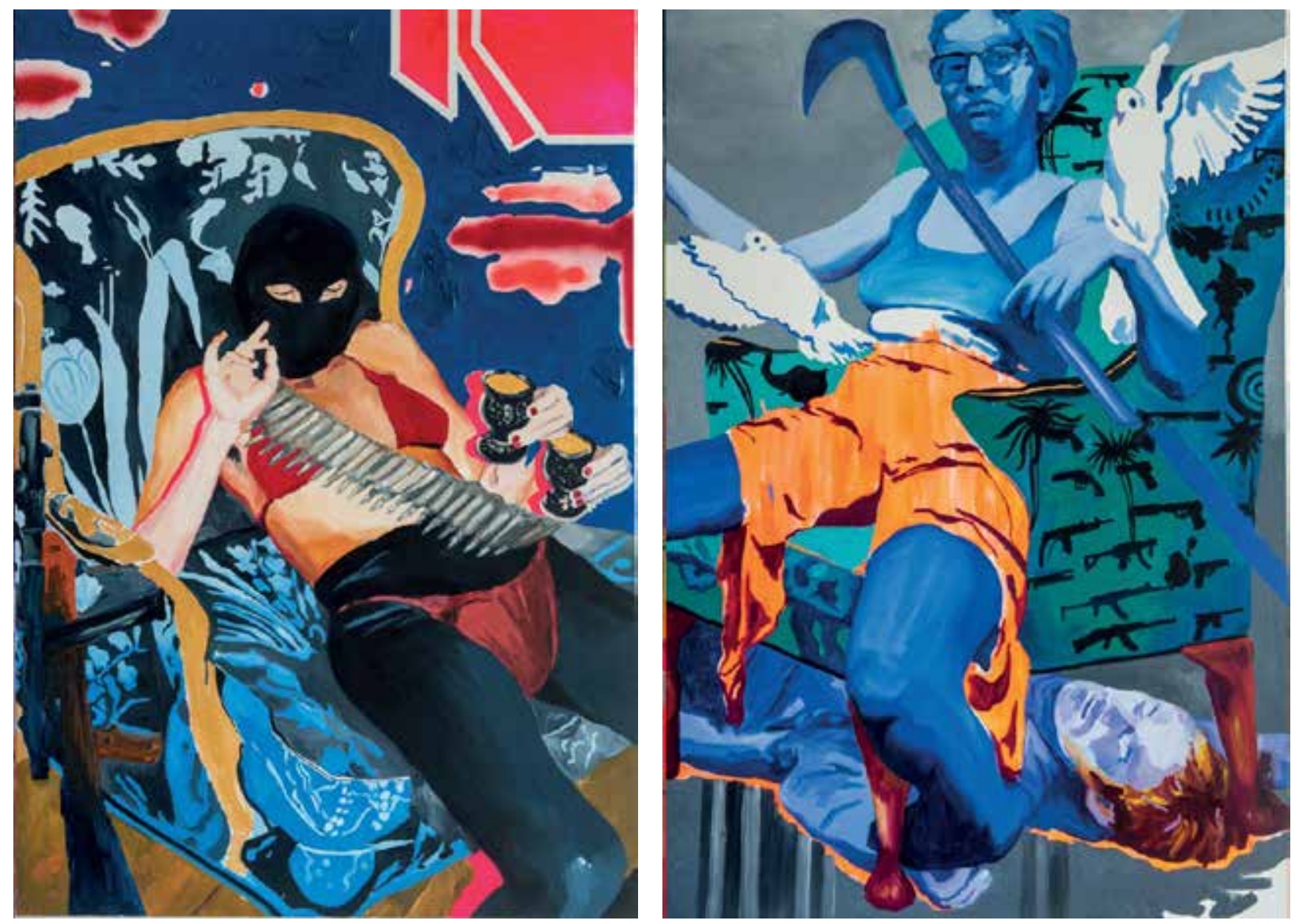

À esquerda: Dama de Copas, da série Rainhas

Óleo, acrílica e spray sobre tela, 175 x $120 \mathrm{~cm}$ 2018

À direita: Dama de Espadas, da série Rainhas Óleo e acrílica sobre tela, 175 × $120 \mathrm{~cm}$ 


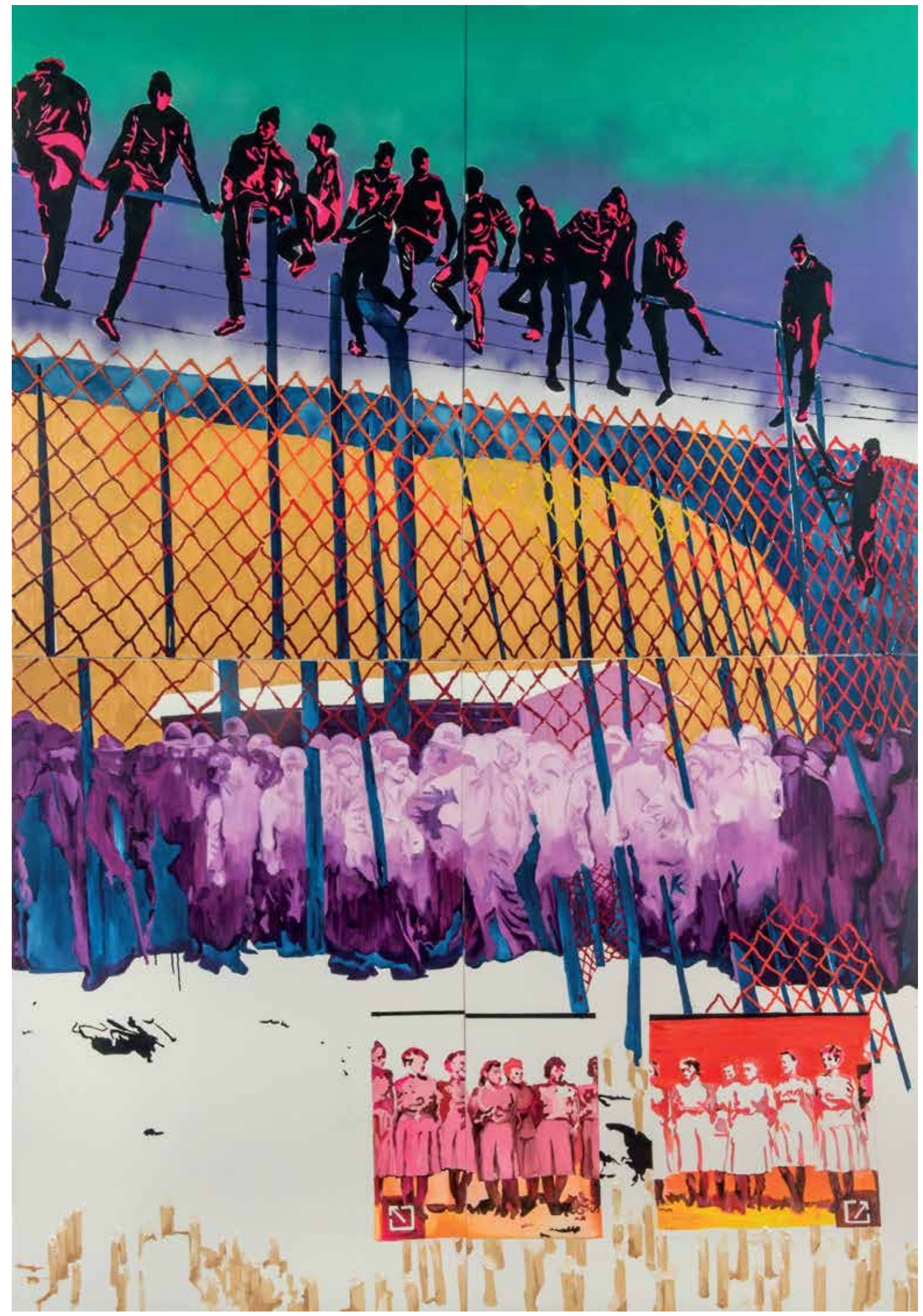

Minha Era, Minha fera

Óleo, acrílica e spray sobre tela, 350 × $240 \mathrm{~cm}$ (políptico)

2018 


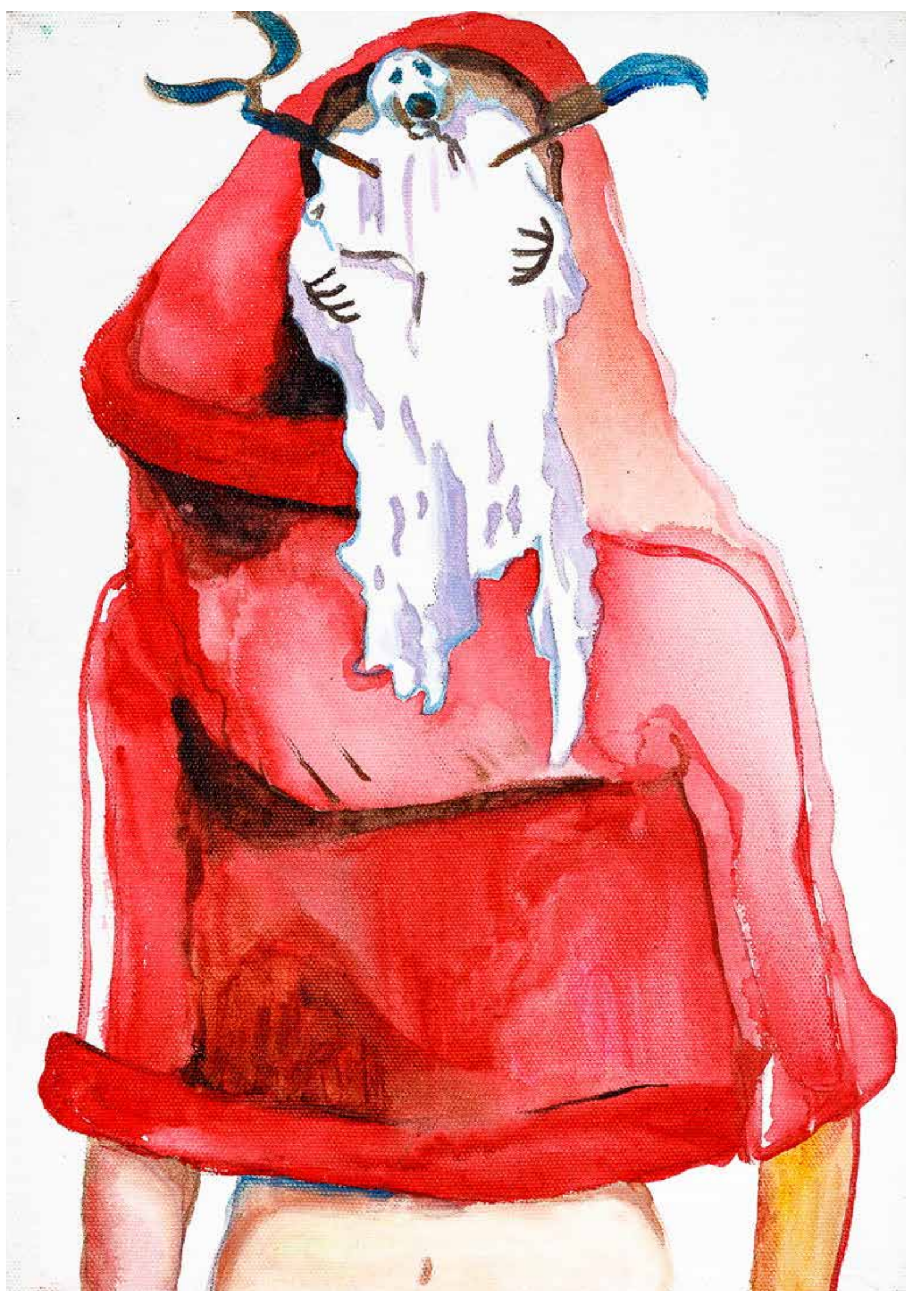

Fantasma do Futuro, da série Castelos no $\mathrm{Ar}$ Acrílica sobre tela, $35 \times 25 \mathrm{~cm}$ 


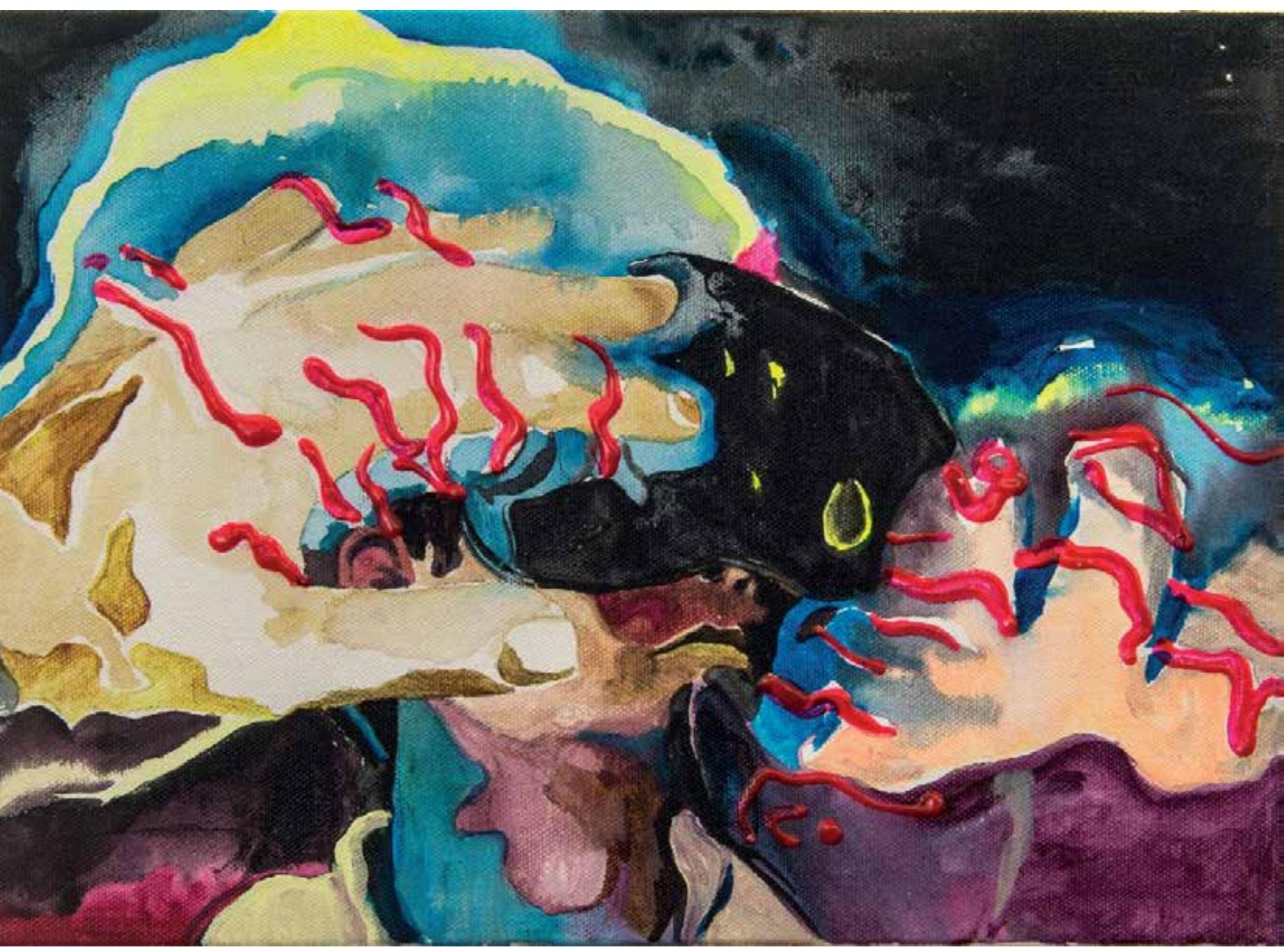

Mão de Cura, da série Castelos no $\mathrm{Ar}$

Acrílica e cola colorida sobre tela, 25 × 35cm

2017 


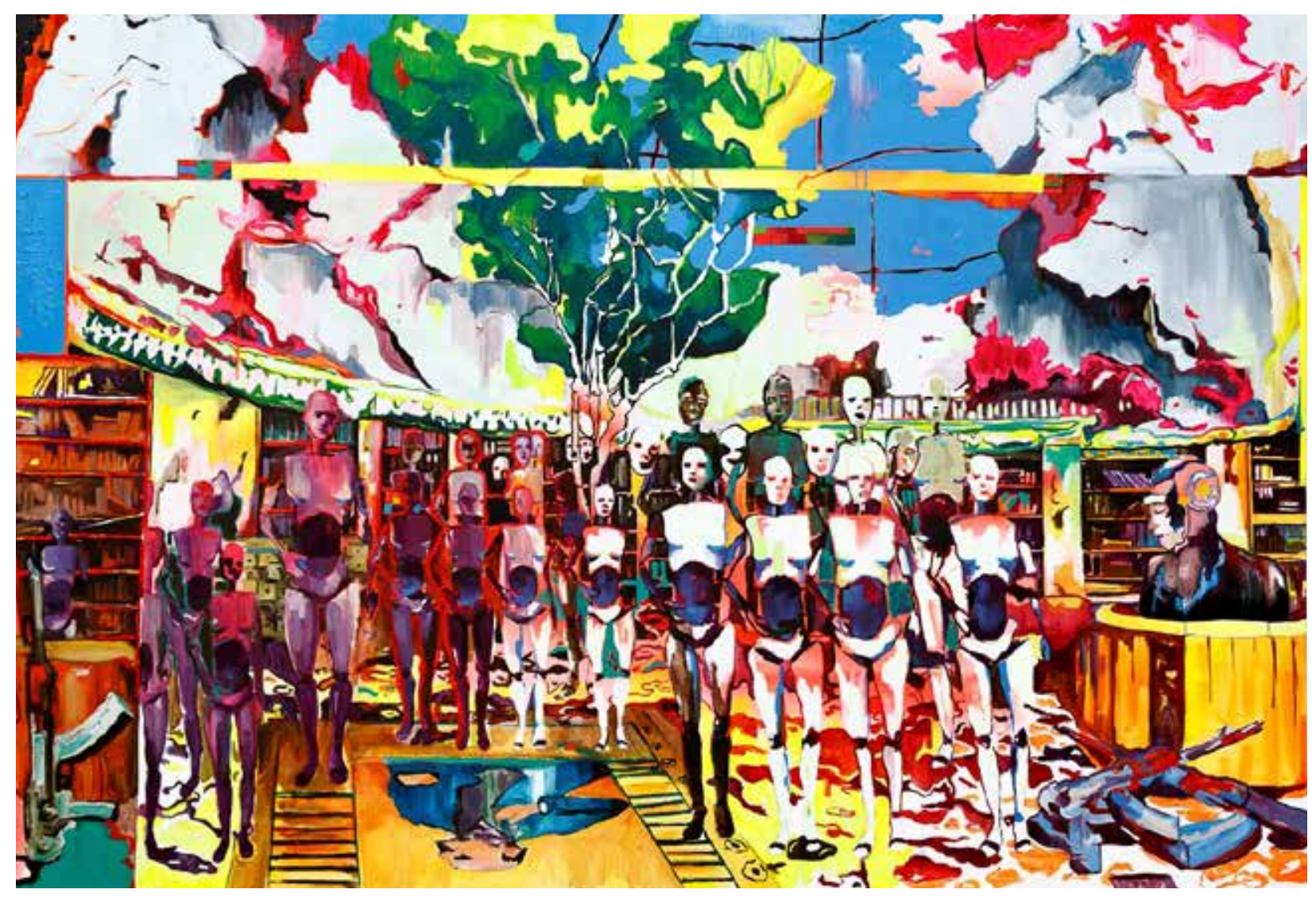




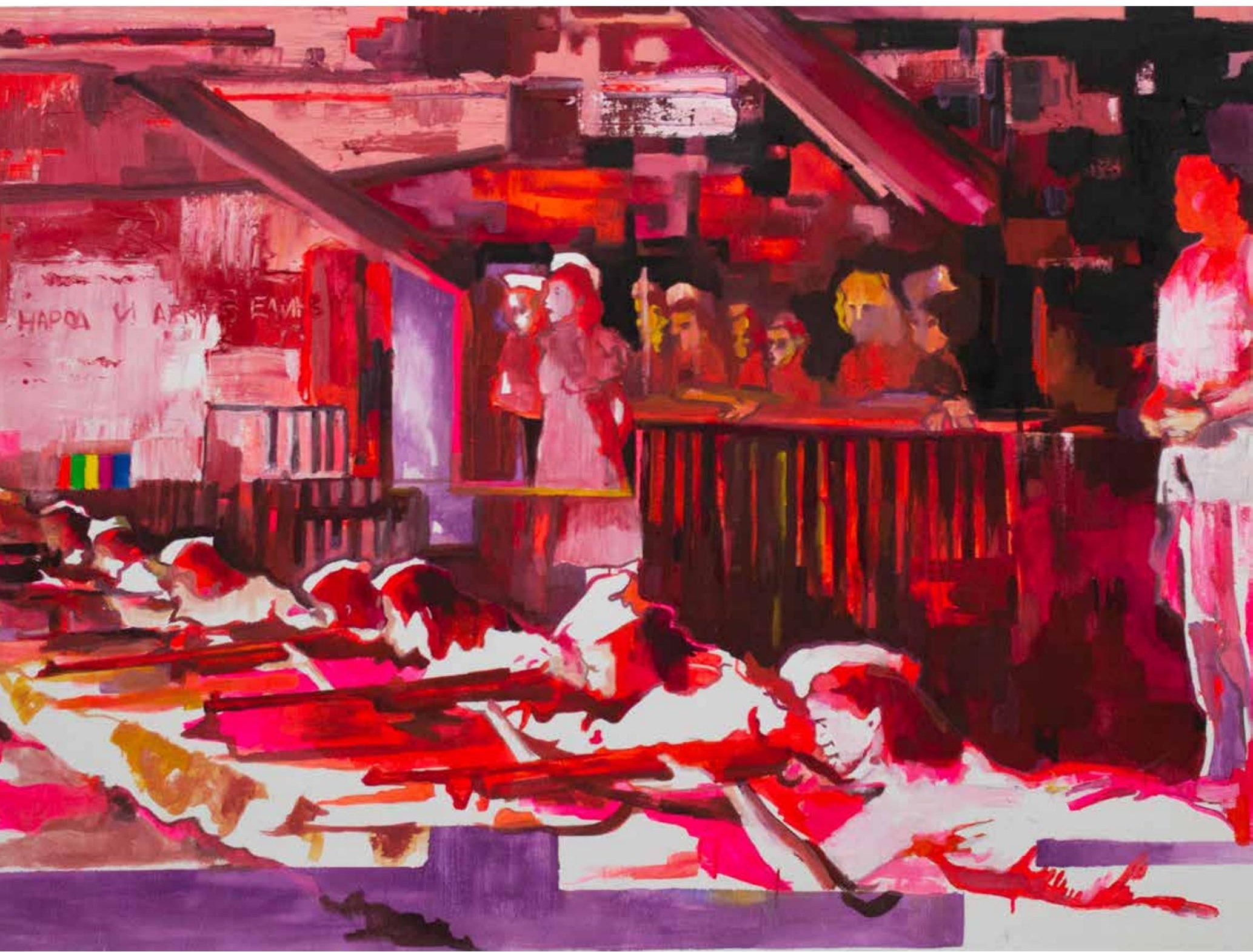

Fogo

Óleo e acrílica sobre tela, 90 x $120 \mathrm{~cm}$

2017

40 Arteriais | revista do ppgartes | ica | ufpa | n. 08 Jun 2019 


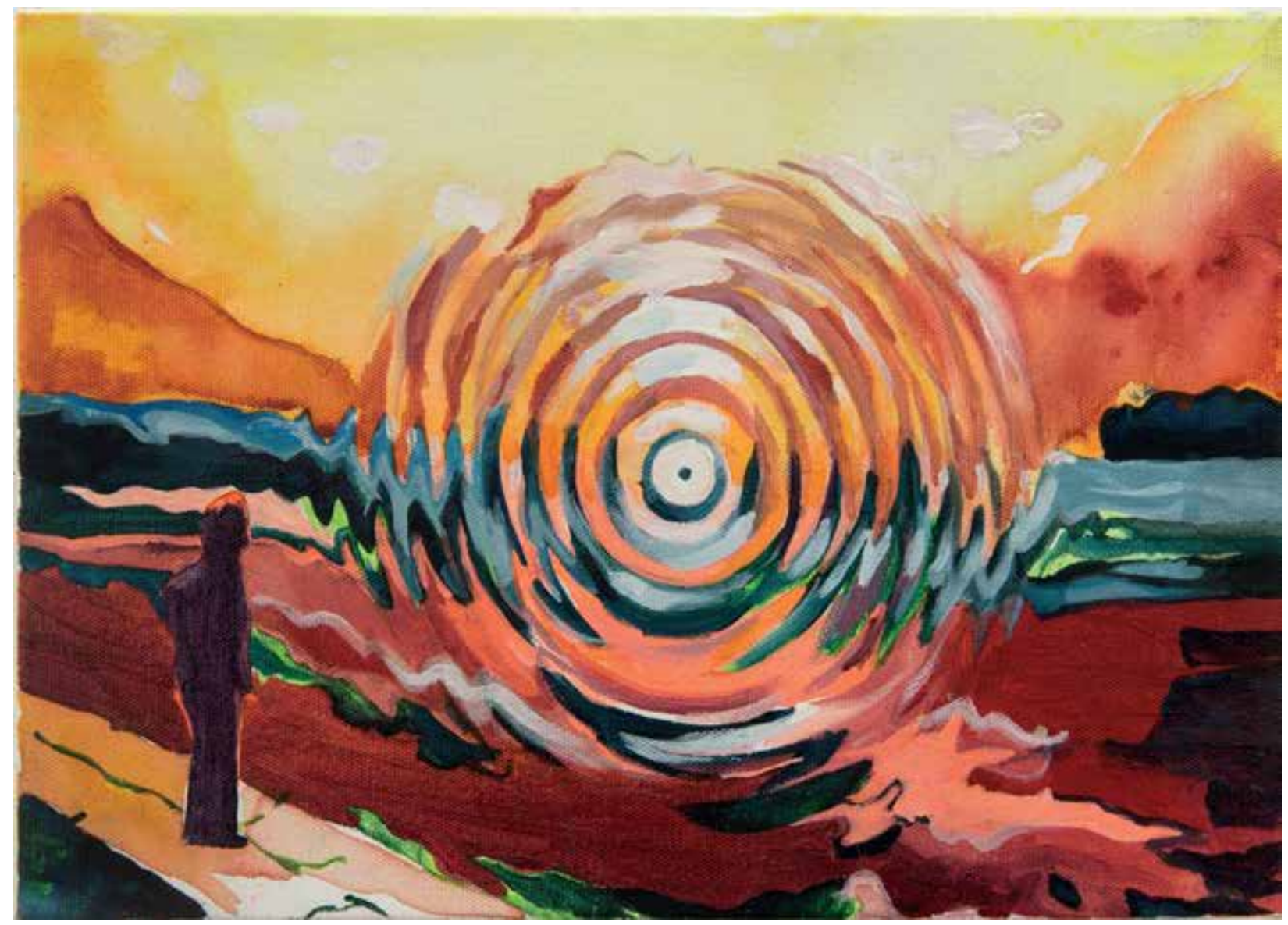

Portal 


\section{Orlando Maneschy (Texto).}

Pesquisador, artista, curador independente e crítico. Doutor em Comunicação e Semiótica pela PUC-SP. Desenvolveu estágio pós-doutoral na Faculdade de Belas Artes da Universidade de Lisboa. É professor na Universidade Federal do Pará, atuando na graduação e pós-graduação. Coordenador do grupo de pesquisas Bordas Diluídas (UFPA/CNPq). É articulador do Mirante - Território Móvel, uma plataforma de ação ativa que viabiliza proposições de arte. Curador da Coleção Amazoniana de Arte da UFPA. Como artista tem participado de exposições e projetos no Brasil e no exterior, como: Outra Natureza, Faculdade de Belas Artes da Universidade de Lisboa, 2015; Horizonte Generoso - Uma experiência no Pará, Galeria Luciana Caravello, Rio de Janeiro, 2015; Transborda, Galeria Casa Triângulo, São Paulo, 2015; Triangulações,Pinacoteca UFAL - Maceió, CCBEU - Belém e MAM - Bahia, de set. a nov. 2014; Pororoca: A Amazônia no MAR, Museu de Arte do Rlo de Janeiro, 2014 etc. Recebeu, entre outros prêmios, a Bolsa Funarte de Estímulo à Produção Crítica em Artes (Programa de Bolsas 2008); o Prêmio de Artes Plásticas Marcantonio Vilaça / Prêmio Procultura de Estímulo às Artes Visuais 2010 da Funarte e o Prêmio Conexões Artes Visuais - MINC | Funarte | Petrobras 2012, com os quais estruturou a Coleção Amazoniana de Arte da UFPA, realizando mostras, seminários, site e publicação no Projeto Amazônia, Lugar da Experiência. Realizou, as seguintes curadorias: Projeto Correspondência (plataforma de circulação via arte-postal), 2003-2008; Projeto Arte Pará 2008, 2009 e 2010; Amazônia, a arte, 2010; Contra-Pensamento Selvagem dentro de Caos e Efeito, com Paulo Herkenhoff, Clarissa Diniz e Cayo Honorato, 2011; Projeto Amazônia, Lugar da Experiência, 2012, dentre outras.

\section{Marcela Cantuária (Portfólio).}

Nascida no Rio de Janeiro em 1991, onde vive e trabalha. Suas obras são apropriações de imagens históricas advindas do universo da política e de representações da cultura visual contemporânea. As invenções pictóricas de Marcela advém de sua pesquisa sobre o protagonismo feminino nas lutas sociais e suas obras são reconexões com fatores sociais apagados ou mal tratados pela história, portanto seu corpo de trabalho dialoga com questões sobre as posições da mulher na sociedade, a luta de classes, as divisões de poderes, os estereótipos de gêneros e as disputas de sentidos políticos. Frames de filmes, imagens jornalísticas, miscelânia figurativa do inconsciente e registros fotográficos do cotidiano figuram corpos de mulheres nuas, militares sangrando, fogo em praça pública, paisagens em chamas, animais domésticos e feras selvagens sobre telas, em planos cruzados e anacrônicos. É bacharel em Pintura pela Escola de Belas Artes da UFRJ. Em 2019 abre, na galeria A Gentil Carioca, a individual "La larga noche de los 500 años", mesmo ano em que realizou "Suturar Libertar" no Centro Municipal de Arte Helio Oiticica e participou das coletivas "Histórias feministas", no MASP e "Estratégias do Feminino" no Farol Santander em Porto Alegre, e das residências PAOS GDL no México e Kaaysa em São Paulo e integra os acervos do Museu da Maré e do MASP. 


\section{COMER A PRÓPRIA CARNE: O MITO PESSOAL COMO DISPARADOR DO PROCESSO DE CRIAÇÃO CÊNICA}

\section{Saulo Vinícius Almeida USP}

\section{Resumo}

Este artigo analisa o conceito de mito pessoal e seus desdobramentos em duas performances teatrais, Sebastian e Cura. Utiliza como base teórica os estudos do mito de Mircea Eliade, os estudos da psicologia profunda em sua relação com os conteúdos mitológicos de Carl Gustav Jung e seus continuadores e os escritos de Grotowski. Propõe a partir do mito pessoal a instauração de uma zona inconsciente de comunicação entre o performer e as testemunhas por via da infecção psíquica.

\section{Palavras-chave:}

Mitopoética; Arquétipos; Teatro ritual; Mito pessoal; Inconsciente.

A pesquisa que dá corpo ao presente artigo se iniciou no ano de 2016 e se estendeu até o final do ano de 2018, dentro do Departamento de Arte Dramática da Universidade Federal do Rio Grande do Sul - UFRGS, sob a orientação da Prof. ${ }^{a}$ Dr. ${ }^{a}$ Luciana Éboli, como Iniciação Científica e se desdobrou em minha monografia de conclusão de curso. O início da pesquisa se deu com a observação da Guarda de Moçambique de Nossa Senhora do Rosário na cidade de Oliveira Minas Gerais. Questões pertinentes ao corpo simbólico, ao tempo espiralar (MARTINS, 2003), ao mito encarnado, à relação de identificação pessoal e coletiva dos grupos com os mitos dançados e às energias transpessoais que atravessam os corpos dançantes se fizeram presentes ao fim do período de observação.

Como trabalhar cenicamente o mito e todas as questões que o atravessam com alunos-atores que não possuem nenhum vínculo cultural, religioso e/ou étnico com uma mitologia específica? Seria possível realizar em cena a atualização de um mito? Seria possível dar corpo às energias transpessoais? Tal questão é abordada por Grotowski (2011), que apontou a impossibilidade de um trabalho efetivo
Abstract

This article analyzes the concept of personal myth and its ramifications in two theatrical performances, Sebastian and Cura. It uses as theoretical base the studies of the myth of Mircea Eliade, the studies of analytical psychology in its relation with the mythological contents of Carl Gustav Jung and its followers and the writings of Grotowski. It proposes from the personal myth the establishment of an unconscious zone of communication between the performer and the witnesses through the psychic infection.

\section{Keywords:}

Mythopoetic; Archetypes; Ritual theater; Personal mith; Unconscious.

com o mito sem que existisse um terreno comum de crenças. 0 encenador-pedagogo afirmou que a relação entre o espectador e o mito encenado se estabelecia cada vez mais de forma pessoal, em um contexto no qual a crença se torna assunto de convicção intelectual.

Como resposta a essa impossibilidade de identificação com o mito, propõe que ao invés da tentativa de identificação com o mito, o ator realize um confronto com o mesmo, encarnando-o para então perceber as relatividades acerca de nossos problemas (os quais atravessariam a narrativa do mito) e a sua conexão com as raízes. Ao tocar as camadas mais íntimas de si e as expôlas, a máscara da vida cairia e a violação desse organismo vivo exposto transportaria a todos para uma situação mítica.

Em Campbell (1990), encontramos uma reflexão próxima. Para o mesmo, o processo de globalização e a pluralidade cultural gerada por esse resultam em uma crescente desmitologização da sociedade. Assim como Carl G. Jung, Mircea Eliade (2016, p. 73) assevera que o inconsciente possui estrutura 


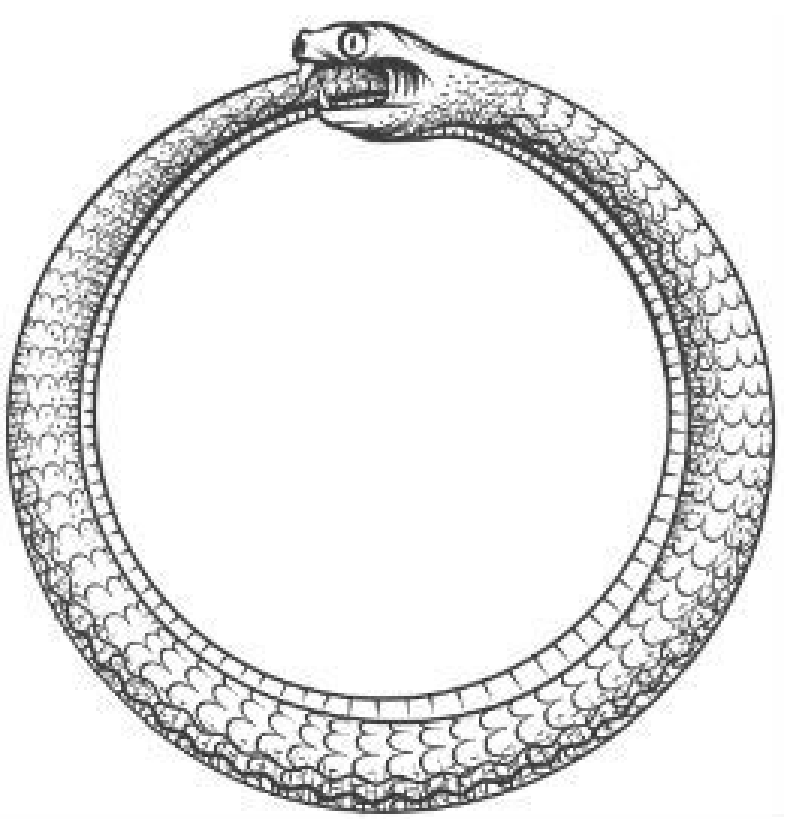

Figura 1 - Ouroboros.

mitológica e a partir dessa prerrogativa, ele resolve o problema da identificação do homem moderno com o mito.

Eis a razão por que o inconsciente apresenta a estrutura de uma mitologia privada. Pode-se ir mais longe ainda e afirmar que não somente o inconsciente é "mitológico", mas também que alguns de seus conteúdos estão carregados de valores cósmicos; em outros termos, que eles refletem as modalidades, os processos e dos destinos da vida e da matéria vivente. Pode-se mesmo dizer que o único contato real do homem moderno com a sacralidade cósmica é efetuado pelo inconsciente, quer se trate de seus sonhos e de sua vida imaginária, quer das criações que surgem do inconsciente (poesia, jogos, espetáculos, etc).

A partir desta perspectiva levantada pro Eliade e dos estudos de Carl G. Jung acerca da estrutura da psique, me valho do conceito de mitologia pessoal proposto por ele (e estudado por David Feinstein e Stanley Krippner (1997) dentro da psicologia e por Renato Cohen (1998) e Luciana Lyra $(2005,2011)$ na práxis cênica), tendo como hipótese que a partir deste e dos conteúdos inconscientes acessados a partir do mesmo tornasse possível instaurar na cena um acontecimento mítico, sendo este de caráter real e sagrado.

Para os pesquisadores David Feinstein e Stanley Krippner (1997), a mitologia pessoal é um sistema de mitos pessoais que oriente o indivíduo e organiza o seu sentido de realidade. Dentro da mitologia pessoal há o mito pessoal que é o conjunto de imagens, sentimentos e crenças deste indivíduo que é organizado em torno de uma temática central de cunho mitológico. Durante a pesquisa, utilizei dois métodos de acesso a essa mitologia pessoal. O primeiro se deu com o confronto ao que Luciana Lyra (2005) denomina de mito guia e o segundo método, desvela a mitologia pessoal e o mito guia a partir da experiência instaurada no confronto com o mitologema proposto pela estrutura de encenação.

A figura mitológica Ouroboros (figura 1) é uma serpente que come a sua própria cauda. Formasse um círculo que em sua significação abarca os grandes ciclos da vida, o tempo, a morte, a ressurreição, a renovação. Nos estudos búdicos, o ouroboros aparece como símbolo do olhar para si e é neste sentido que compreendo o mito pessoal. A partir de um olhar para si, devorasse em um movimento de autoantropofagia, em que o indivíduo alimentasse de suas memórias e de seu corpo para chegar até a sua essência. É de um ator autoantropofágico em uma cena ourobórica que se alimenta de sua concretude e de sua virtualidade, tendo no acontecimento a razão única de seu fazer, que se tratam os dois experimentos cênicos que abordarei e analisarei brevemente.

\section{1 - SEBASTIAN E O MITO DE SÃO SEBASTIÃO}

Durante o ano de 2017, construí o espetáculo Sebastian, no qual assino a direção. Esse processo de criação se deu a partir do mito guia de São Sebastião, o qual o ator compreendeu que por diversas questões e experiências acausais constitui sua identidade e atravessa a forma como o mesmo percebe o mundo. São Sebastião é um mártir da mitologia católica que segundo as narrativas religiosas teria sido assassinado em 20 de janeiro de 288. Ainda jovem ingressou na Guarda Pretoriana, sendo brevemente elevado ao cargo de comandante de sua unidade militar. Utilizou-se então deste posto para ter acesso aos calabouços e consolar os crentes cristãos. S. Sebastião ocultou sua fé de seus superiores na Guarda. O imperador ao descobrir tal fato e também as ações que Sebastião cometia em nome de Cristo ordenou que o mesmo fosse sacrificado. O mártir católico teve seu corpo amarrado e flechado (SALOMÃO, 2008). 


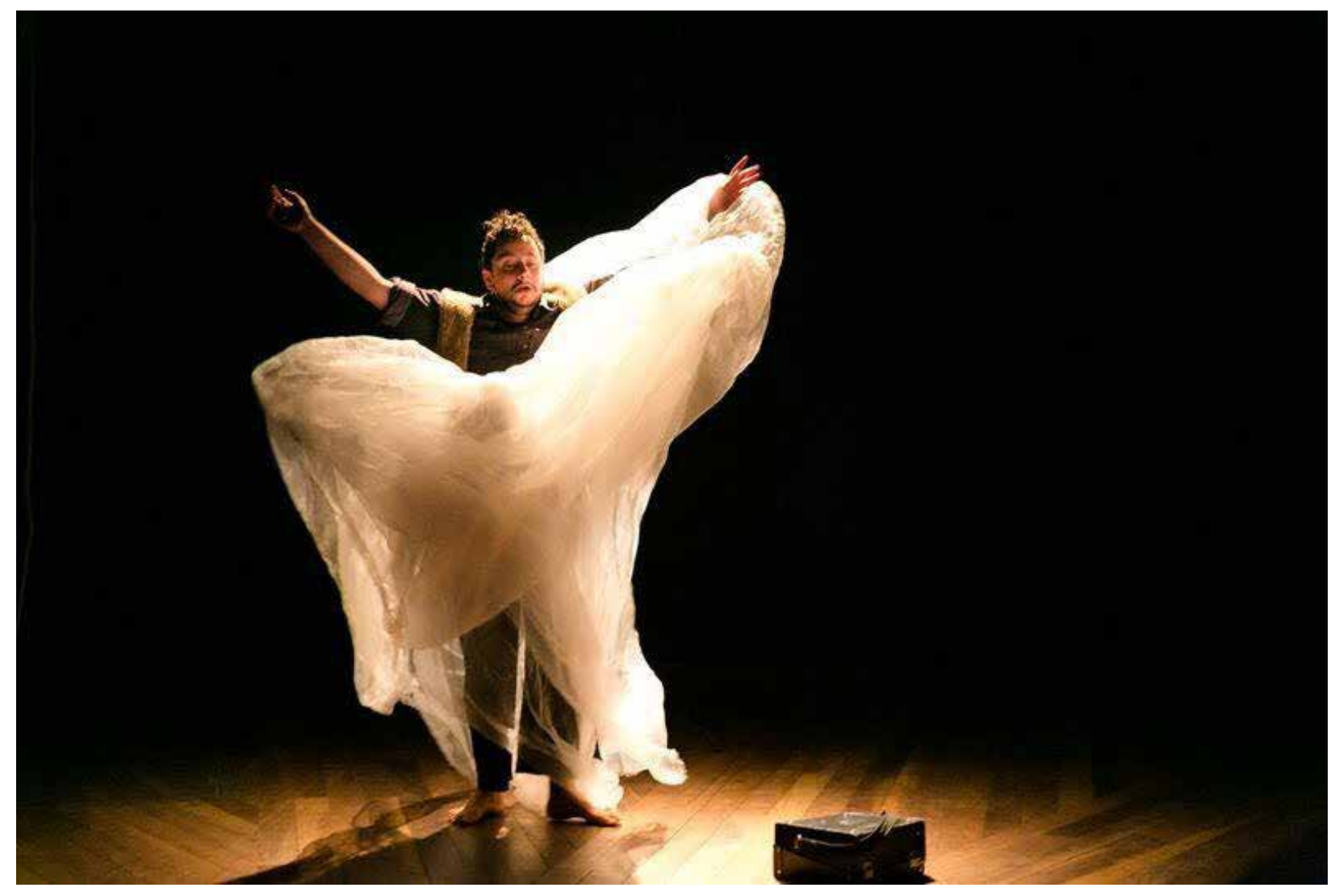

Figura 2 - Espetáculo Sebastian I.

O corpo desfalecido foi entregue a uma cristã de nome Irene, a qual verificou que o mesmo ainda estava vivo. Após alguns dias, estando curado, retorna ao palácio e desafia o imperador ordenando que se arrependesse de seus atos contra os cristãos. O imperador, por sua vez, ordena que Sebastião fosse espancado até a morte e que seu corpo fosse tratado como um dejeto após o seu falecimento e atirado numa fossa. Com o passar dos séculos, a figura de São Sebastião se tornou o padroeiro dos gays, assumindo nas suas representações um aspecto erotizado. Na umbanda, é tido como sincretismo do Orixá Oxossi. (SALOMÃO, 2008)

A tessitura cênica se construiu a partir de duas camadas distintas. Na primeira, realizou-se um aprofundamento no trabalho com o mito por parte do performer por vias da irracionalidade e do inconsciente. Na outra camada, por meio de uma sobreposição de elementos cênicos, criou-se uma estrutura textual de encenação.

O processo de direção se valeu da estrutura básica de um ritual de sacrifício (MAUSS; HUBERT, 2005), de modo que para cada momento deste ritual foi proposto ao ator que este construísse uma resposta corpórea a partir da relação que se estabelecia entre suas experiências de vida e alguma célula significante do seu mito guia. Em um primeiro momento, os resultados cênicos se davam com características do que Jung (2013b) entendeu como gênero introvertido. Para o autor existem dois movimentos psicológicos nos quais se constituem os processos de criação artística, o introvertido e o extrovertido. "O gênero introvertido caracteriza-se pela afirmativa do sujeito e de suas intenções e finalidades conscientes em oposição às solicitações do objeto; em contrapartida, o gênero extrovertido é caracterizado pela subordinação do sujeito às solicitações do objeto" (JUNG, 2013b, p. 74).

Jung (2013b) entende a obra de arte como um processo que de certo modo é autônomo ao sujeito. Para ilustrar essa questão, ele propõe a imagem de uma planta e o solo na qual ela se encontra. A arte, assim como a planta, possui vida e seus próprios processos que são alimentados e possibilitados pelo solo, ou seja, pelo artista. Quando este, o artista, trabalha de 


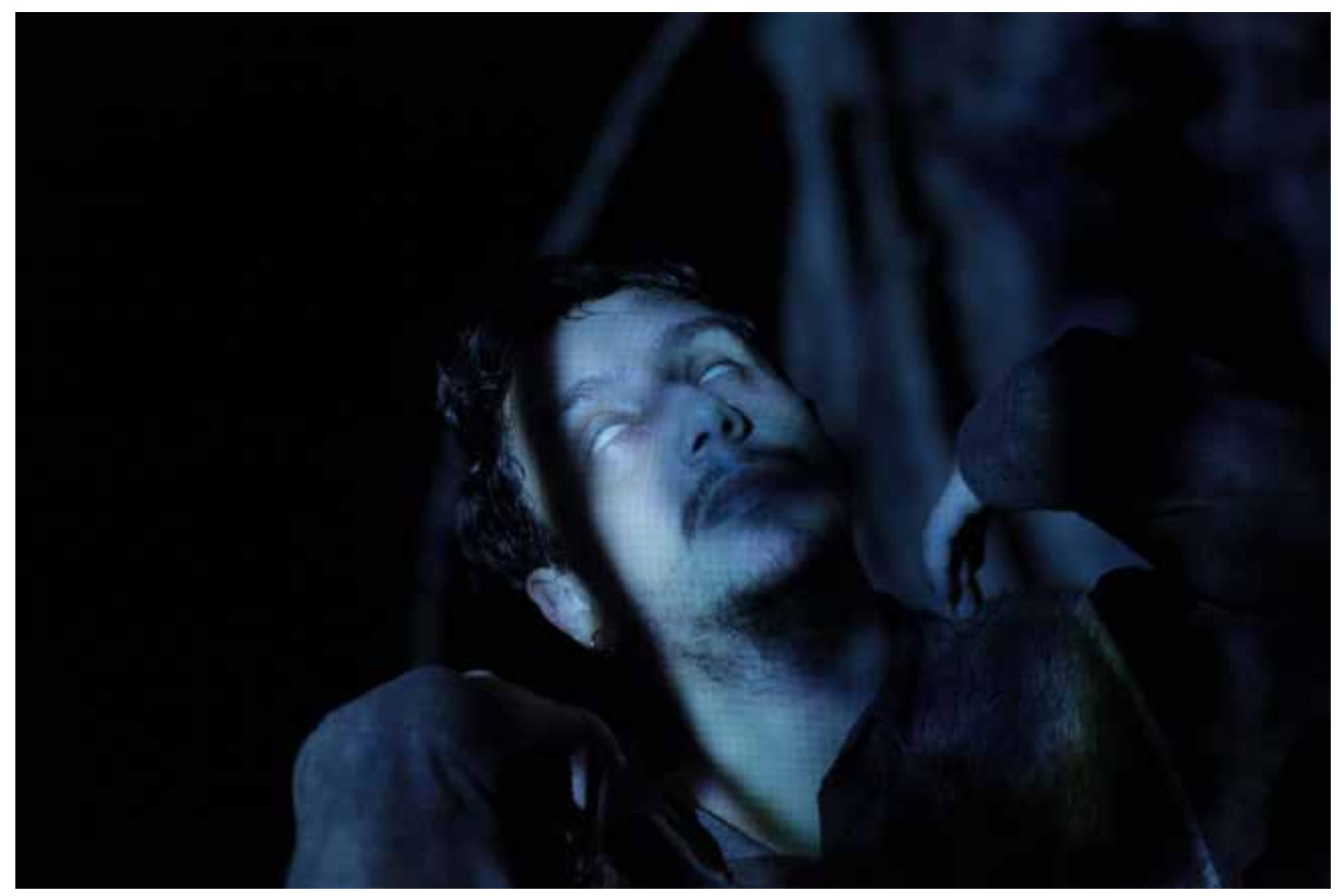

Figura 3 - Espetáculo Sebastian II.

modo introspectivo, esperasse uma obra que não ultrapasse os limites do intencionado, do signo calculado.

Grotowski (2010, 2011), sobre seu processo de criação, faz apontamentos que compreendo como uma característica de criação extrovertida, a saber: "Percebi que a montagem levou à consciência ao invés de ser o produto da consciência" (GROTOWSKI, 2011, p. 15) ou quando discutindo sobre o encontro gerado pelo desvelamento do mistério humano diz que "Talvez não seja o único caminho rumo ao teatro, mas considero que nesse caminho somos muito mais devorados por aquilo que fazemos" (GROTOWSKI, 2010, p. 181).

A partir desta prática e aceitando a premissa de que a esfera mitológica da psique se encontra além da zona consciente, no que Jung (2000b) denomina como inconsciente coletivo, nós buscamos mecanismos para ultrapassar a criação introvertida e tornar o corpo mais permeável para o fluxo de imagens de caráter arquetípico. Segundo Mircea Eliade, "o inconsciente apresenta a estrutura de uma mitologia privada. Pode-se ir mais longe ainda e afirmar que não somente o inconsciente é "mitológico", mas também que alguns de seus conteúdos estão carregados de valores cósmicos" (2016, p. 73).

Trabalhamos com o intuito de realizar um rebaixamento do consciente, em consonância com a psicóloga e cientista da religião Lilian Wurzba (2011) que em seu estudo sobre as relações entre a dança e o sagrado aponta que a partir do rebaixamento da consciência, ocorre uma diminuição no sentido de orientação e isso permite que conteúdos do inconsciente ascendam a zonas conscientes do indivíduo. Jung (2014, p. 29) propõe que o contrário também é verdadeiro:

Os arquétipos são fatores formais responsáveis pela organização dos processos psíquicos inconscientes: são os patternsofbehaviour (padrões de comportamento). Ao mesmo tempo, os arquétipos têm uma "carga específica": desenvolvem efeitos numinosos que se expressam como afetos. $O$ afeto produz um abaissement de niveau mental (baixa do nível mental) parcial, porque, justamente na mesma medida em que eleva um determinado conteúdo a um grau supranormal de luminosidade, retira também tal quantidade de energia de outros conteúdos possíveis da consciência, a ponto que esses se tornam obscuros e inconscientes. 


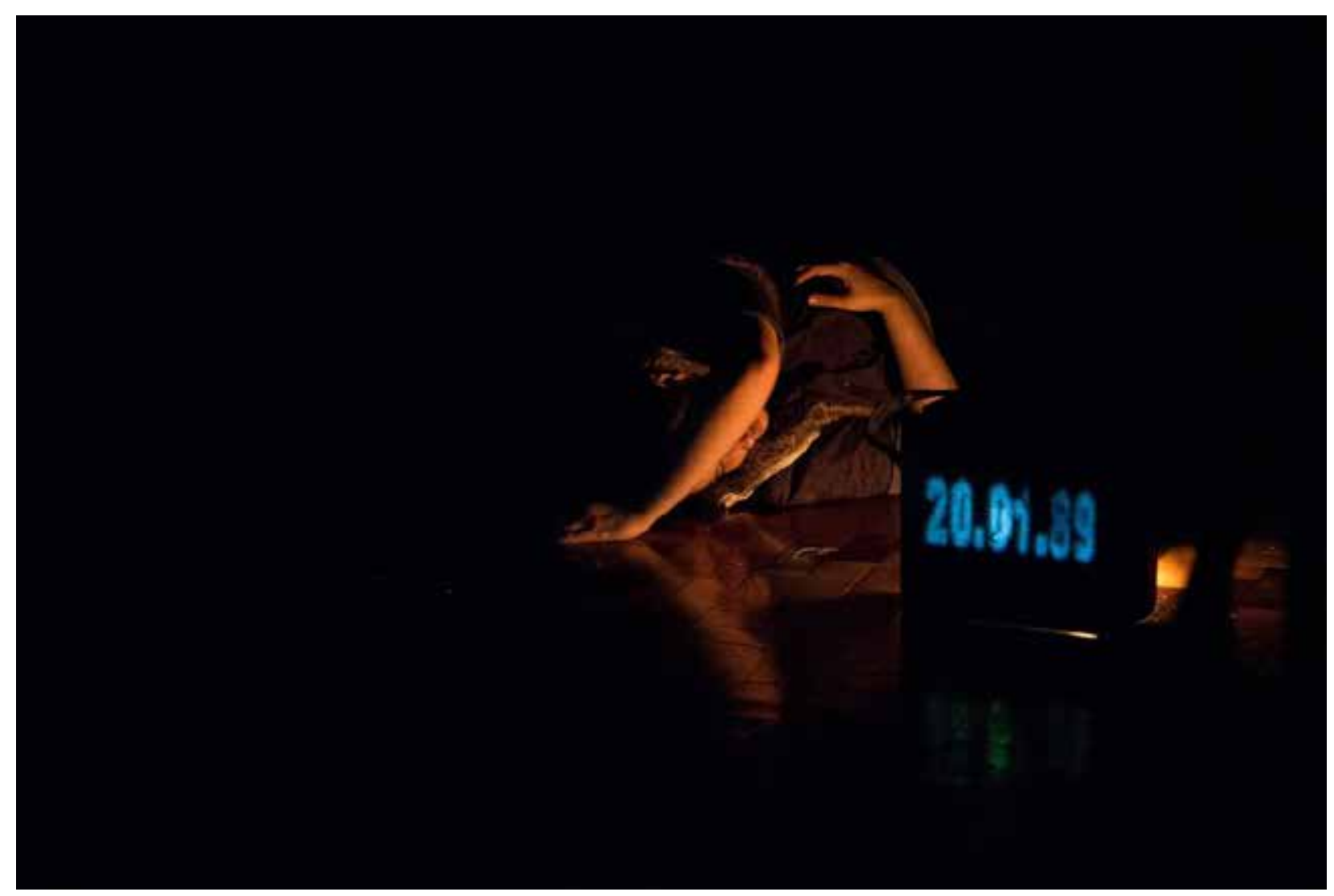

Figura 4 - Espetáculo Sebastian III.

Esse processo ocorreu em sala de ensaio a partir de exercícios energéticos ligados a poética dos elementos materiais de Bachelard (1989), de práticas de exaustão e pela dança pessoal, a qual ocorria durante várias horas seguidas e neste processo flertou com os princípios e a estética do Butoh. Para o diretor Ushio Amagatsu, "o butoh é mais uma tentativa de articular a linguagem corporal do que de transmitir alguma ideia e visa proporcionar a cada espectador uma viagem particular ao seu mundo interior" (apud BAIOCCHI, 1995, p.17).

Esta fase do trabalho passou por dois momentos distintos, um que se relaciona com lembranças e outro que se afastou das questões de cunho extremamente pessoais e se materializou a partir de imagens simbólicas coletivas. Essas duas fases por muitas vezes ocorriam seguidamente, como elos seguidos de uma corrente. O exercício que se iniciava nas sensações física desembocava na experiência do afeto, para então abrir fendas para a constelação de lembranças e para as experiências que compreendo como de caráter arquetípico.
Jung (2000a) acerca das lembranças aponta que aquelas que estão perdidas do espectro consciente se encontram, junto com os conteúdos reprimidos de forma mais ou menos intencional no que ele domina de inconsciente pessoal. Durante os laboratórios percebemos diversas camadas de lembranças que retornavam à pele. Memórias próximas que surgiam como um reviver-se de características causais, ou seja, uma lembrança gerava o elo para o surgimento de outra. Em outra camada que entendemos como mais profunda, surgiam, rompendo com essa sequência de lembranças iniciais, vivências e sentimentos esquecidos que quando atualizados no corpo geraram outra qualidade de presença e transformação do tônus e das dinâmicas de movimento.

Sendo a biologia, a cultura e a história pessoal partes do que se entende como mitologia pessoal é compreensível esse tipo de experiência durante o processo. Ocorre que tais experiências não são suficientes para justificar a utilização do mito pessoal como realmente um processo numinoso de construção cênica ou mesmo como sendo um processo distinto do que se compreende como 


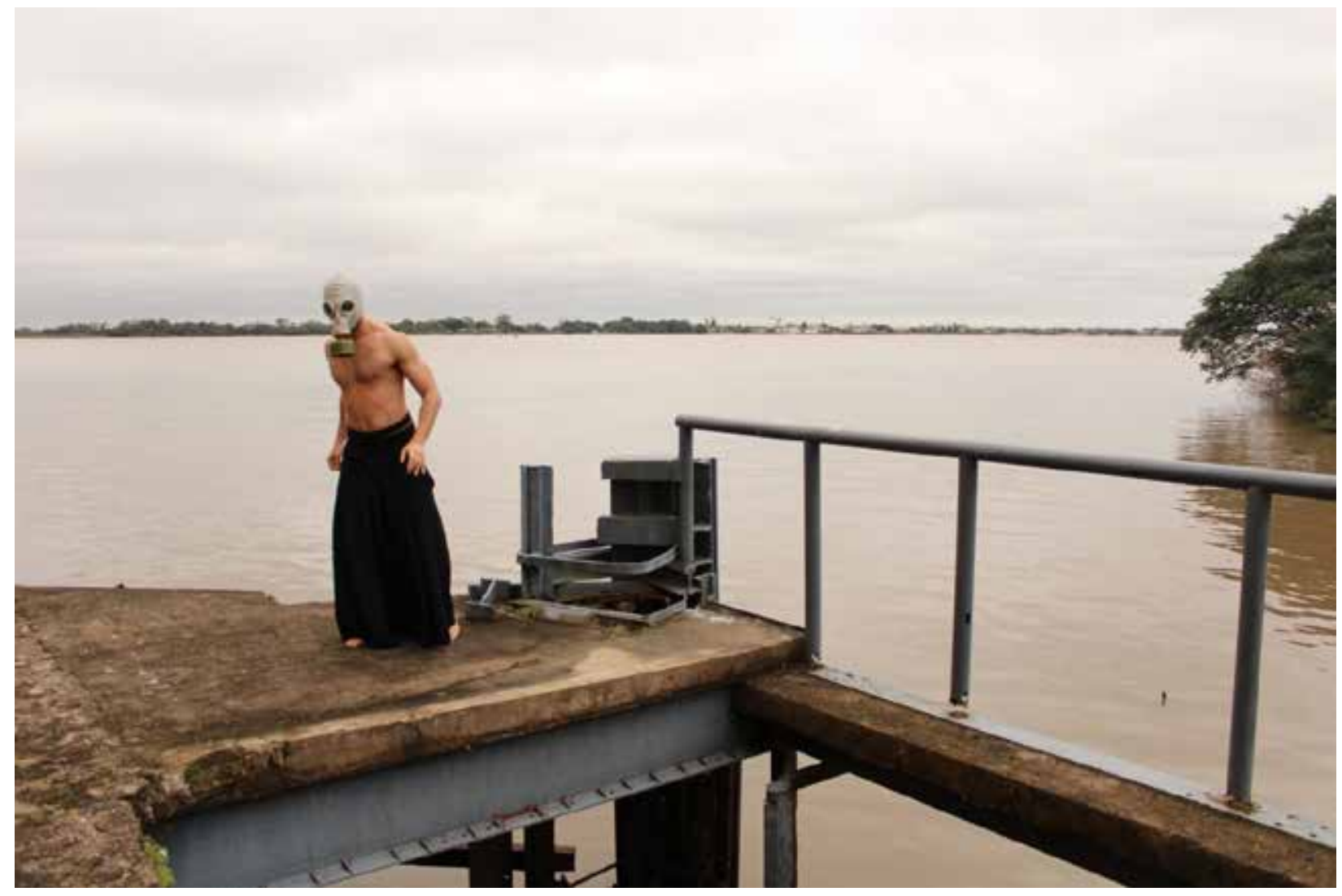

Figura 5 - Espetáculo Cura I.

criação auto narrativa ou biodrama. Contudo, a insistência nesses exercícios e a fricção destes com os estímulos baseados no mito guia geraram ao longo do tempo momentos que compreendo como de caráter arquetípico, ou seja, momentos nos quais imagens humanas universais e originárias com caráter numinoso eram acessadas.

As lembranças, quando surgiam se atualizando nesse corpo em estado de trabalho modificavam imediatamente a qualidade da presença do ator, assim como as dinâmicas do seu corpo no espaço. Nas situações que compreendi como de caráter arquetípico, inicialmente, podiamse observar os mesmos efeitos de quando surgiam as lembranças, contudo, o corpo se comportava de maneira distinta, assumindo no seu conjunto de movimentos a construção de figuras ou movimentos de caráter simbólico. "Afora as recordações pessoais, existem, em cada indivíduo, as grandes imagens 'primordiais' [...], ou seja, a aptidão hereditária da imaginação humana de ser como era nos primórdios" (JUNG, 2015, p. 39). Acompanhando essa modificação de dinâmica concreta do ator, houve também modificações na percepção tempo-espacial, seja por parte do ator, seja por parte das pessoas que testemunharam o acontecimento.

\section{2 - CURA, O MITOLOGEMA DA VIAGEM NOTURNA SUBMARINA}

Durante o ano de 2018, construí na função de ator o espetáculo Cura, com o intuito inicial de experimentar no corpo as percepções que obtive enquanto diretor. Acho interessante frisar que mesmo na distância que o ato de dirigir propicia com relação à experiência cênica, meu corpo foi sempre atravessado, tomado, transformado com o acontecimento possibilitado e presentificado no instante pelo corpo do ator. Afinal, como o próprio Jung aponta, "ninguém mexe com fogo ou veneno sem ser atingido em algum ponto vulnerável" (2015, p. 116).

No espetáculo Cura, proponho não utilizar o mito guia como estratégia para a experiência numinosa, mas sim utilizar de um mitologema e a partir da estrutura propiciada pelo mesmo, experienciar o trabalho da mitologia pessoal. O mitologema, segundo James Hollis (2005), é um elemento ou tema isolado em qualquer mito. 


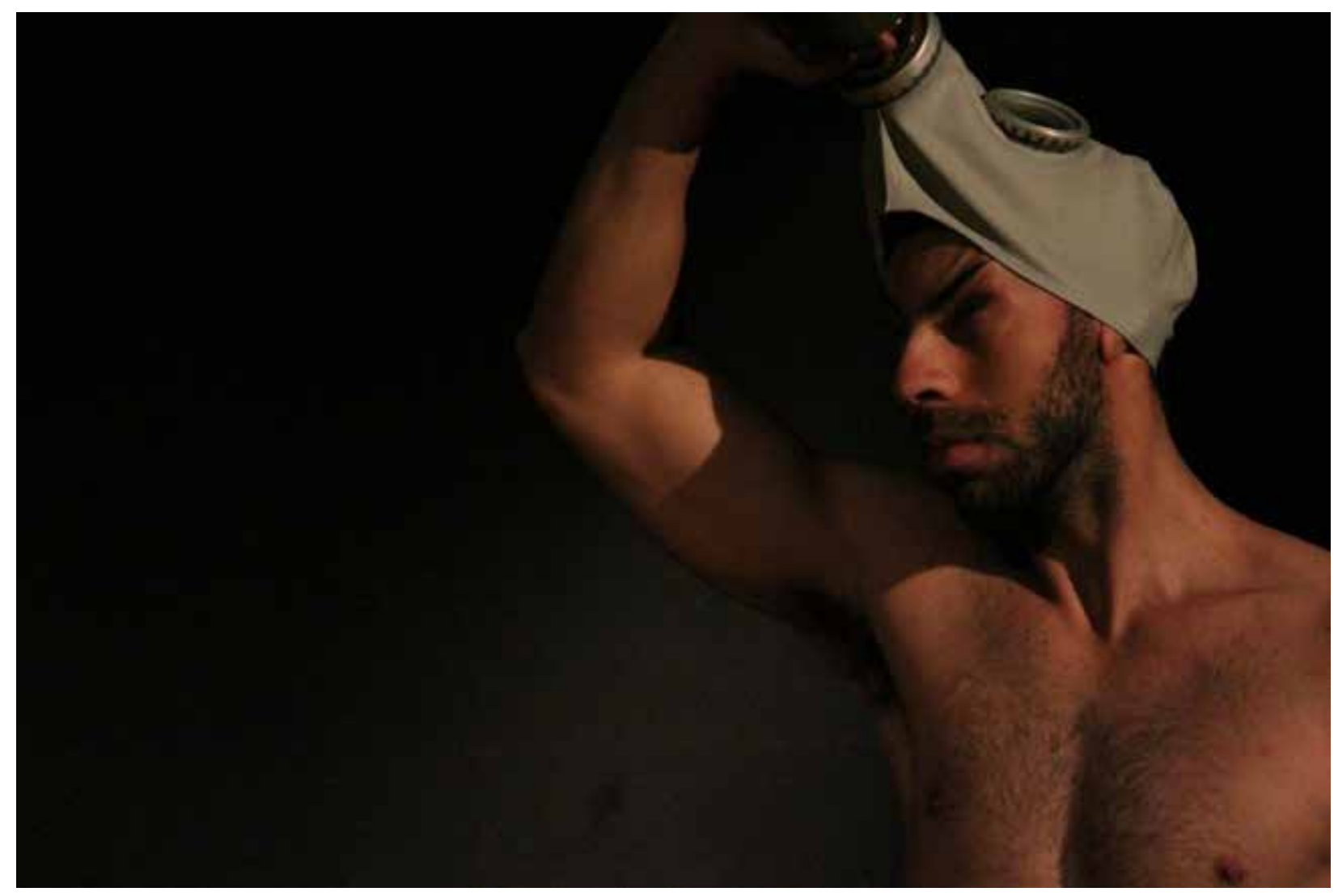

Figura 6 - Espetáculo Cura II.

A Viagem Noturna Submarina é a estrutura básica que alicerça inúmeros mitos. Nela há a morte do herói, o seu mergulho na escuridão e seu retorno transformado. Campbell (1990) nos dá o exemplo do mito de Jonas e a baleia, neste, Jonas é engolido e na barriga da baleia é levado ao abismo, para então ressuscitar. Realizando uma leitura simbólica deste tema mítico, o autor explica que a água, assim como em praticamente todos os estudos de simbologia nos quais podemos encontrar a mesma compreensão, representa o inconsciente e a baleia, psicologicamente, é o poder de vida contido neste inconsciente que por ter dominado a consciência necessita ser controlada e superada.

O primeiro estágio desse tema mítico, segundo Joseph Campbell (1990), é aquele em que o herói abandona a família e se encontra a beira das águas nas quais o peixe, a baleia ou o monstro vem a seu encontro. Num segundo estágio, já dentro da barriga, o herói se depara com uma energia de caráter inconsciente que não é capaz de controlar e disso se derivam como consequências as provações que como em uma jornada o mesmo terá que ultrapassar para em um terceiro estágio renascer a uma nova vida.
Jung (2012a, p. 350) faz uma leitura deste mitologema que corrobora com a apontada por Campbell. Para o autor, "a obscuridade e a profundeza do mar significam apenas o estado inconsciente de um conteúdo que é projetado de modo invisível" e a saída do herói do monstro submarino equivale ao reestabelecimento da vida e a ressurreição da morte. Para o autor, o que leva o herói em um mito a essa descida as profundezas é a possibilidade de se encontrar um tesouro, seja este uma virgem ou a vitória da vida sobre a morte. Esse mergulho é o mergulho profundo em si mesmo, o mergulho ao Hades.

Esta estrutura pode ser identificada em alguns sonhos e em hinos citados por Jung (2000b) no decorrer de sua obra:

Este sonho mostra-nos o simbolismo natural. O sonhador desce à sua própria profundeza, e o caminho o leva à água misteriosa. Ocorre então o milagre da piscina de Betesda. Um anjo desce e toca a água que adquire então poder curativo. No sonho, é o vento, o pneuma, que sopra onde quer. É necessário que o homem desça até a água, a fim de que se produza o milagre da vivificação (p. 27-28) 
No hino gnóstico à alma, o Filho é enviado pelos pais à procura da pérola perdida que caíra da coroa real do Pai. Ela jaz no fundo do poço profundo, guardada por um dragão, na terra dos egípcios - mundo e concupiscência e embriaguez com todas as suas riquezas físicas e espirituais. O filho e herdeiro parte à procura da jóia, e se esquece de si mesmo e de sua tarefa na orgia dos prazeres mundanos dos egípcios, até que uma carta do pai o lembra de seu dever. Ele põe-se então a caminho em direção à água e mergulha na profundeza sombria do poço, em cujo fundo encontra a pérola, para oferece-la então à suprema divindade (p.28)

Durante o processo de criação deste espetáculo, que se valeu de exercícios próximos aos empregados na construção do espetáculo Sebastian, a imagem de uma ave surgiu no processo de criação da penúltima estrutura cênica e tornou-se um elemento de grande importância cênica. Este símbolo não estava de acordo com os percursos que havíamos traçado até então e muito menos com o mitologema em questão. Contudo, deparei-me com outra versão destra estrutura mítica, apresentada por Jung (2013a) em seu estudo sobre a energia psíquica. Neste estudo, o pesquisador aponta que o sair do corpo da baleia se dá com a ajuda de um pássaro que é simultaneamente o nascer do sol.

Temos neste acontecimento do surgimento do pássaro a ilustração de um caso de sincronicidade.

A sincronicidade, portanto, significa, em primeiro lugar, a simultaneidade de um estado psíquico com um ou vários acontecimentos que aparecem como paralelos significativos de um estado subjetivo momentâneo e, em certas circunstâncias, também vice-versa(JUNG, 2014, p. 35).

Um conteúdo inesperado que está ligado direta ou indiretamente a um acontecimento objetivo exterior, coincide com o estado psíquico ordinário: é isto o que chamo de sincronicidade, e sou da opinião que se trata exatamente da mesma categoria de eventos, não importante que sua objetividade apareça separada da minha consciência no tempo e no espaço (JUNG, 2014 , p. 39, grifo do autor).

O artista-pesquisador e professor Renato Cohen (1998, p. 70) utilizou a noção de sincronicidade em sua tese de doutoramento para entender acontecimentos presentes em processos de criação que tinham como linha de trabalho a irracionalidade. Este conceito levanta a questão da relação tempo/ espaço na práxis cênica. Cohen compreende que no trabalho com o mito e no âmbito da irracionalidade há um deslocamento da lógica logo temporal para uma lógica espacial, uma lógica do mythos.
Trabalho de fundo, subliminar, dimensionando o atuante em outra sintonia, por processos de imersão (física, psíquica, temporal), através de trabalhos de atenção, estranhamento, alteração de dinâmicas, possibilitando a emergência de conteúdos internos, a alternância de referenciais e, principalmente, a criação de um campo de sincronicidades.

A sincronicidade, conforme estudada por Jung (2014, p. 28-29) é uma relativização do tempo e do espaço que se comportam com características elásticas em relação à psique.

Nas experiências com o tempo e o espaço, respectivamente, esses dois fatores reduzem-se mais ou menos a zero, como se o espaço e o tempo dependessem de situações psíquicas, ou como se existissem por si mesmos e fossem "produzidos" pela consciência. Na concepção original do homem (isto é, entre os primitivos), o espaço e o tempo são coisas sumamente duvidosas.

Segundo Wurzba, quando "os processos racionais conscientes são arrebatados pela irracionalidade inconsciente, ocorre uma relativização do ego e, consequentemente, uma relativização também das categorias de tempo e espaço" (2011, p. 93). A autora aponta em sua pesquisa que embora se possa dividir o tempo real em quatro categorias, o tempo cinético, o tempo rítmico, o tempo programado de execução e o tempo narrativo, a experiência da dança propicia que o homem se desloque do tempo e penetre o vazio. Fora do tempo, ele abandona o seu espaço e chega ao infinito. Os movimentos então deixariam de ser realizados por essas pessoas e seriam realizados então por forças transpessoais (WURZBA, 2011).

O corpo se torna, nesse contexto, tanto canal pelo qual o material contido no inconsciente coletivo se externaliza quanto matéria na qual a energia desse processo age. Jung (2013a) em seu estudo sobre a energia psíquica, diz que existe a possibilidade de essa estar ligada intimamente ao processo físico, podendo por meio de processos fisiológicos, transformar-se em energias físicas. O corpo se torna um tradutor e o discurso do inconsciente no mundo, sendo a linguagem simbólica o vernáculo.

A viagem no mundo ou submundo inconsciente da psique no processo de criação se deu também no universo onírico dos sonhos. Um dos fatores constituintes da sincronicidade (JUNG, 2014,p. 41) é a transposição de imagens da inconsciência para a consciência pela via indireta dos sonhos, associações ou premonições. Dentre os casos em 


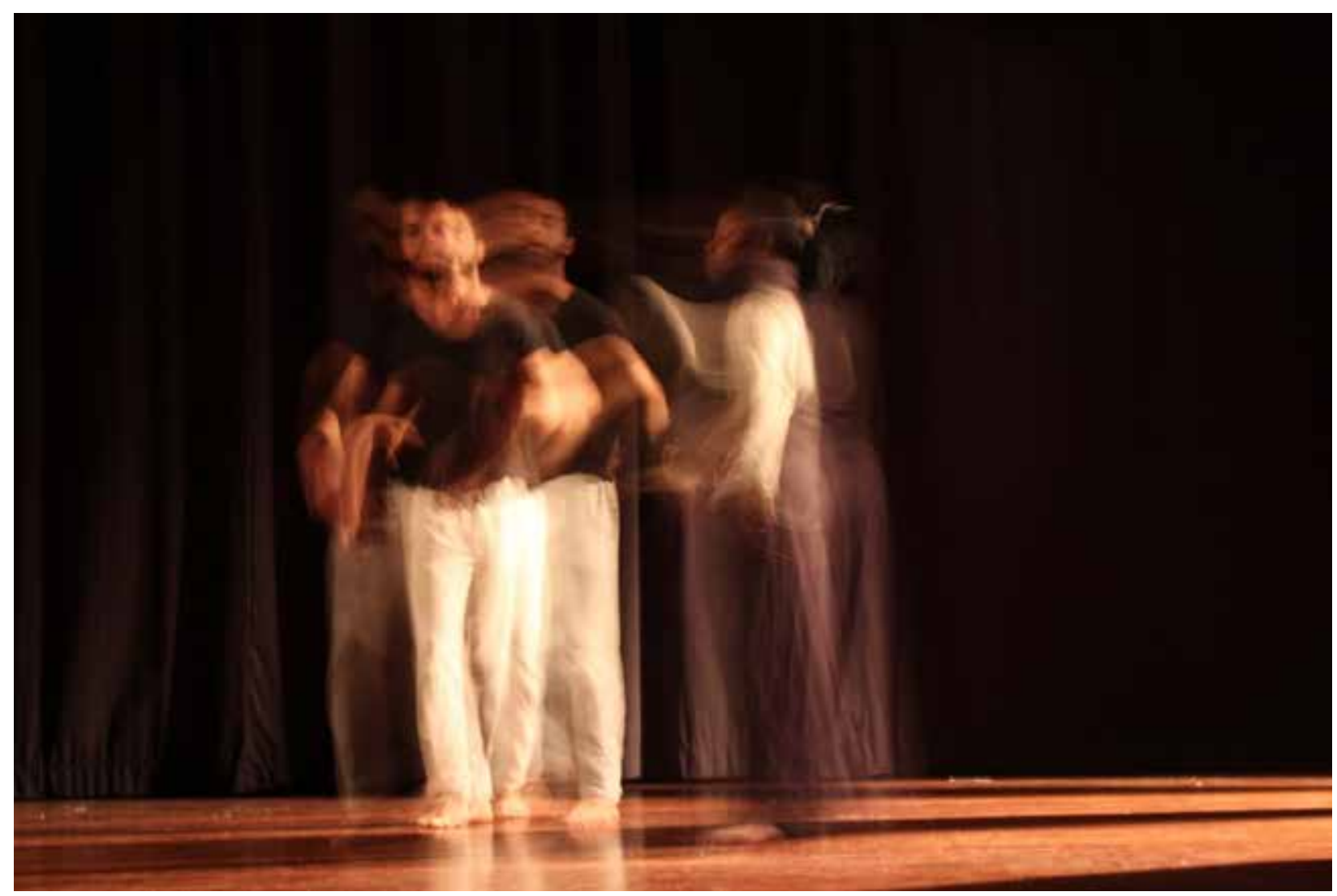

Figura 7 - Ensaio do espetáculo Cura.

que isto ocorreu neste processo, ressalto dois sonhos em que conteúdos referentes ao processo cênico apareceram. Os sonhos envolviam jogo de búzios, tarot, baralho cigano e uma professora do departamento com a qual tive praticamente três aulas durante quatro anos de curso.

Após o relato dos conteúdos destes sonhos à professora em questão, obtive como resposta que inúmeros elementos que os constituíam equivaliam a realidades de sua vida, as quais eu não teria como ter acesso e conhecimento. Com o passar do tempo, percebi que várias informações contidas nos sonhos, como por exemplo, uma modificação de elementos materiais que apareceu nas cartas de tarot, começou a ocorrer na criação cênica. Novamente estava defronte a características de um processo extrovertido de criação. A obra se fazia por si gerando apenas uma ilusão de controle por minha parte consciente.

As categorias de análises causais tornam-se inúteis para os processos que explodem com a lógica racional da criação. O sentido, o texto, o ponto de partida e de chegada não possuem importância. No universo do mito a narrativa não é do logos. "Na física moderna, parece, por vezes, que o efeito ocorreu antes da causa e, portanto, os físicos tentam darIhe uma viravolta e dizer que ainda podemos chamar isso de causal" (FRANZ, 1993, p.8).

\subsection{1 - SÍSIFO - A ECLOSÃO DO MITO PESSOAL}

O mitologema se tornou um caminho a ser seguido na construção do exercício cênico, na instauração do acontecimento. Em momento algum houve o intuito de se criar uma narrativa transformando o acontecimento em uma história ou mesmo a estruturação de personagens ou personas. A proposta era que o ator, no caso eu, percorresse os fluxos de energia identificados na estrutura base e que o corpo se tornasse um espaço de mediação entre os universos concretos e imaginários que coexistem e se atravessam e constroem-se no ato presente.

Ao longo dos ensaios, identifiquei uma série de sinais que me trouxeram a consciência o mito de Sísifo. Utilizo o termo sinais no sentido empregado por Erna van de Winckel (1985) que os compreende como "subdivisões, ramificações dos símbolos 


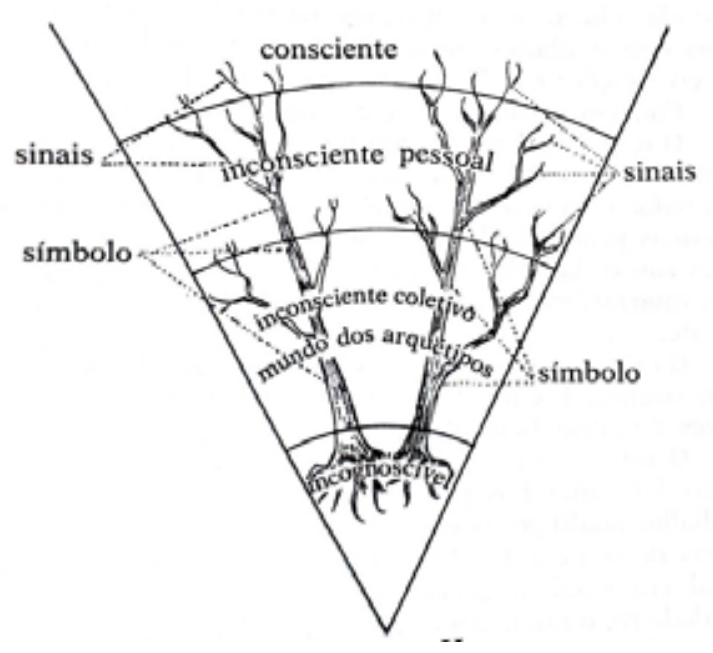

Figura 8 - Esquema de símbolos e sinais proposto por Winckel.

primordiais" e que "frequentemente são muito numerosos e às vezes parecem bem afastados de seu sentido primeiro" (p. 32).

Este mito narra a experiência de sofrimento de Sísifo que devido a um castigo dos deuses, passa a eternidade em um trabalho extenuante e repetitivo de arrastar um bloco imenso com as mãos até o cume de um morro e quando finalmente chegava próximo à realização da tarefa, a pedra, em função de seu peso e da gravidade, rolava para baixo e nisso reiniciava-se a tarefa (KAST, 2017). Vários elementos desta narrativa passaram aos poucos a tornarem-se presentes, desde os elementos materiais contidos no mito, até motivos físicos, energias, tensões corpóreas, desistências em meio ao processo e a incapacidade de se formular a cena final.

É de se esperar que a cena elaborada a partir de exercícios de criação pautados na irracionalidade (que tomam práticas como desequilíbrio, exaustão, hiperventilação como mecanismos disparadores do processo criativo) desvincule-se das estruturas narrativas e possibilitem a eclosão da vida em seu caráter mítico. Levando-se em consideração que o mito pessoal é "a representação dramática da nossa vida instintiva mais profunda... passível de inúmeras configurações, da quais dependem todas opiniões e atitudes particulares" (FEINSTEIN; KRIPPNER, 1997, p. 35) e que

sua mitologia é o produto de quatro fontes interatuantes. A biologia, a cultura e a história pessoal são as mais óbvias. Uma quarta fonte originasse de experiências transcendentes - aqueles episódios, percepções interiores, sonhos e visões cuja qualidade numinosa parece expandir nossa compreensão e inspirar nosso comportamento (p. 179-180).

Renato Cohen (1998, p. 66), sobre as experiências em terreno mítico no fazer teatral diz que "a cena mítica, momento de permeação ou de reapresentação do fenômeno primeiro, investe-se pelo seu caráter direto com a experiência, plena de visibilidade e sensação, de uma potência superior à narrativas e relatos".

Este caráter direto com a experiência se possibilita , segundo o autor, a partir de uma ampliação da presença, seguida da inteireza, adensamento e exacerbação por parte do atuante na ação presente. Esse conjunto de atitudes "diminuem as demandas energéticas para atender às vicissitudes do cotidiano e o participante passa a operar mais pleno, tendo acesso, principalmente, à sua mente subliminar, não objetiva" (COHEN, 1998, p. 67). Essa inteireza rompe, em minha perspectiva, com as distinções interno/externo, tornando assim o corpo vivente, o mito em ação. Independente de assumir ou não o mito guia como gatilho de criação, não há como desvincular-me de minha existência e minha constituição psíquica e desta forma, a mitologia pessoal sempre se fará presente em minhas respostas aos estímulos externos e quanto mais integro estiver, mas visível se tornará a dimensão arquetípica, confluindo para o que a psicóloga e professora Rosa Maria Farah chama de vivência poética arquetípica.

\section{2 - A CENA MITOPOÉTICA}

$\mathrm{Na}$ zona liminar da iluminação do conteúdo inconsciente para o espaço da consciência, ocorre o que Jung denomina como função transcendente da psique e que o médico brasileiro Walter Boechat (2016) em uma continuidade dos estudos junguianos identifica como função mitopoética da psique ou simplesmente função mitopoética.

Por "função transcendente" não se deve entender algo de misterioso e por assim dizer de suprassensível ou metafísico, mas uma função que, por sua natureza, pode-se comparar com uma função matemática de igual denominação, e é uma função de números reais e imaginários. A função psicológica e "transcendente" resulta da união dos conteúdos conscientes e inconscientes (JUNG, 2000a, p.13)

A discussão dessa função justificasse por possibilitar que presumíveis experiências de caráter 


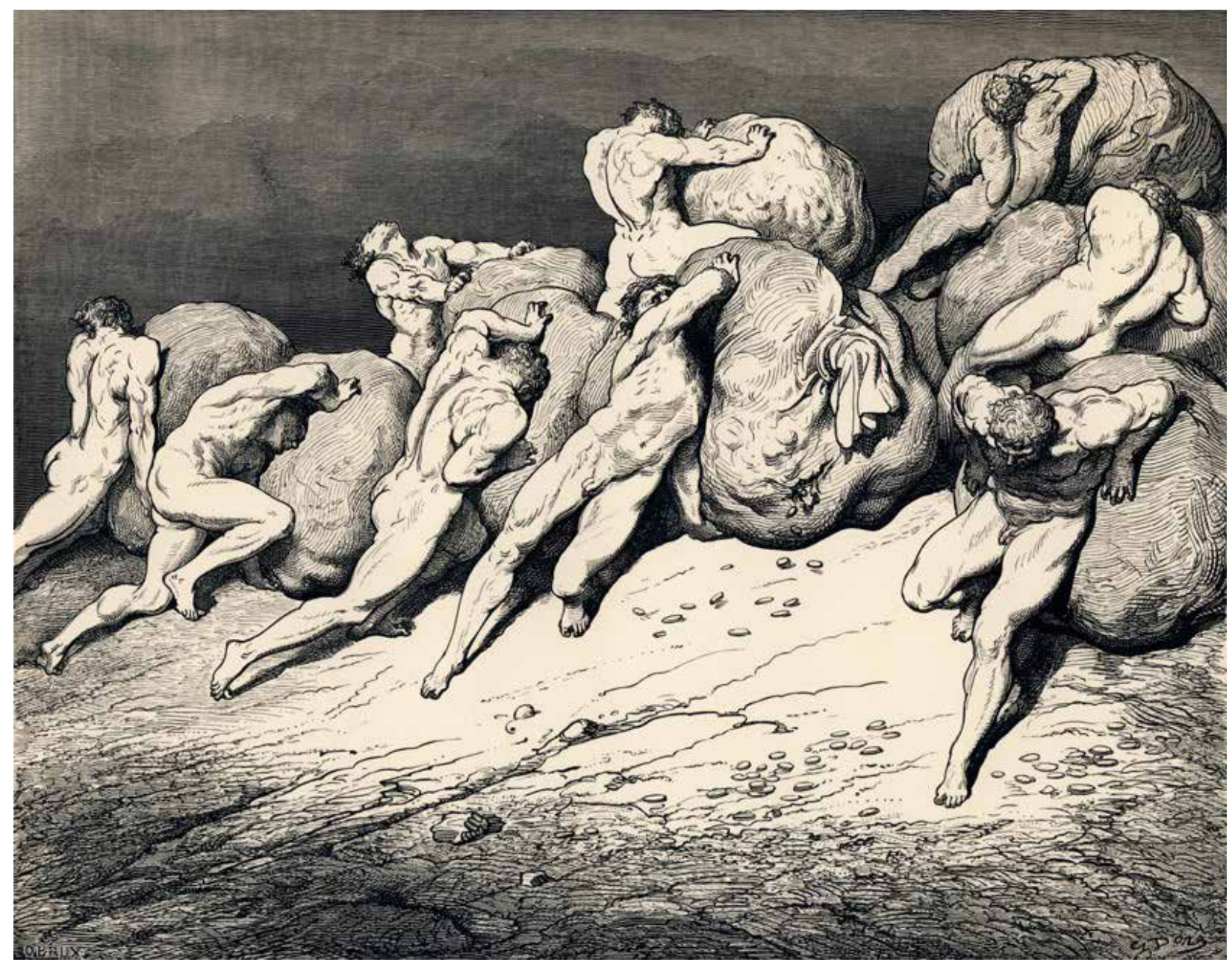

Figura 9 - Sísifo empurrando sua rocha.

primordial do não eu da alma atinjam o espaço da consciência e desse modo o espaço concreto externo ao sujeito, se tornando assim caminho para um experimento performático. Além disto, o arquétipo quando aparece, seja em sonho ou na vida, ele traz, segundo Jung (2015), uma força que confere a este um caráter numinoso.

Antes de adentrar a discussão acerca deste tema, friso que um conceito embora tente apreender a realidade, não passa de um nome e como tal não é possível ser experienciado. Faz-se necessário, então, que se investigue na vivência o conjunto dinâmico de relações às quais a conceituação tenta dar conta abarcando-o em um nome. O conhecimento e a compreensão se possibilitam no contato, no contágio com a ideia concretizada que se abriu pela experiência.

A experiência da vida dita concreta é uma experiência psíquica. Os sentimentos, os pensamentos são formados a partir de imagens psíquicas, o mundo só é possível na medida em que o ser humano é capaz de produzir sua imagem (JUNG, 2015). Jung em uma leitura metafísica compreende o homem como um ente cativo e confinado em sua psique, e essa impressão profunda de cativeiro gera a propensão de "admitir na psique a existência de coisas que desconhecemos e a que denominamos o inconsciente" (2015, p. 196). A existência psíquica, para o autor, seria a única que pode ser demonstrada diretamente, já que o mundo só passa a existir através da criação de sua imagem pelo ser psíquico.

Consideramos a matéria como uma realidade tangível e cognoscível. Entretanto, essa matéria é uma noção absolutamente metafísica, hipostasiada por cérebros não críticos. A matéria é uma hipótese. Quando se fala em matéria, está se criando, no fundo, um símbolo de algo que escapa ao conhecimento, e que tanto pode ser o espírito como qualquer outra coisa; pode ser inclusive o próprio Deus (p. 193). 


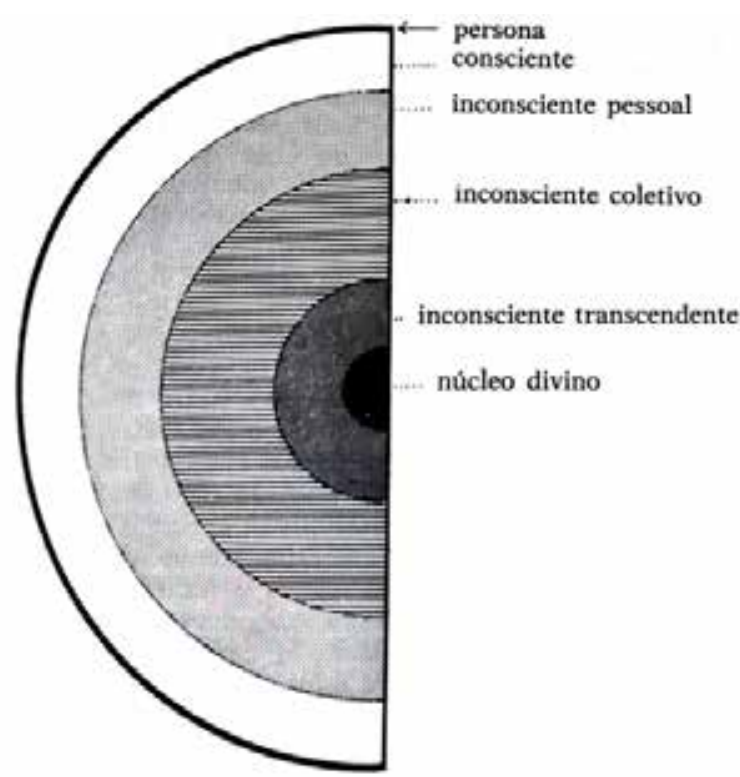

Figura 10 - Corte da célula psíquica proposto por Winckel.

Os exercícios cênicos apresentados nesta pesquisa se propuseram a pensar a práxis cênica a partir da consciência de que "o homem está contido na sua própria psique" (JUNG, 2015, p. 195). Esta forma de se pensar o fazer afastasse do construir e mostrar para a dimensão do revelar. Se

\begin{abstract}
formos capazes de conciliar-nos com o mistério de que o espírito é a vida do corpo, vista de dentro, e o corpo é revelação exterior da vida do espírito, se pudermos compreender que formam uma unidade e não uma dualidade, também compreenderemos que a tentativa de ultrapassar o atual grau de consciência, através do inconsciente, leva ao corpo e, inversamente, que o conhecimento do corpo não tolera uma filosofia que o negue em benefício de um puro espírito (JUNG in WURZBA, 2011, p. 91-92).
\end{abstract}

No exercício com o mito no âmbito da irracionalidade se busca revelar o espírito, as camadas profundas da psique, tanto do indivíduo como as de caráter coletivo. O corpo tornasse um corpo simbólico, mitopoético, parte da função transcendente.

$\mathrm{Na}$ função transcendente ou mitopoética, o inconsciente atua de modo compensatório em relação ao consciente. Por meio de sonhos, delírios, devaneios e pela imaginação ativa o inconsciente compensa a atitude consciente do indivíduo. O material tornado consciente pode ser resultante de experiências pessoais ou apresentar conteúdo de tonalidade impessoal, coletiva (BOECHAT, 2008).

Durante os dois exercícios cênicos citados, notamos um percurso instaurado pela memória, a entendendo dentro do desenho da imaginação proposto por Bachelard (1898 p. 17-18):

A imaginação não é, como sugere a etimologia, a faculdade de formar imagens da realidade; é a capacidade de formar imagens que ultrapassam a realidade, que cantam a realidade. É uma faculdade de sobre-humanidade. Um homem é um homem na porção em que é um super-homem. Deve-se definir o homem pelo conjunto das tendências que o impelem a ultrapassar a humana condição. Uma psicologia da mente em ação é automaticamente a psicologia de uma mente excepcional, a psicologia de uma mente tentada pela exceção: a imagem nova enxertada numa imagem antiga. A imaginação inventa mais que coisas e dramas; inventa a vida nova, inventa mente nova; abre olhos que têm novos tipos de visão. Verás se tiver visões.

Esse percurso se traçou da seguinte maneira: memória recente $\rightarrow$ memória antiga/infância $\rightarrow$ imagem arquetípica $\rightarrow$ arquétipo $\rightarrow$ modificação de gesto e da sensação tempo/espacial.

\section{1 - AS ÁGUAS DE SEBASTIAN}

Durante o exercício cênico Sebastian, solicitei ao ator Ian Habib que trabalhasse partir da memória do dia em que ocorreu uma modificação física importante em seu corpo. Pensando-se a processualidade do exercício, a resposta foi extremamente agressiva, contudo não gerou nenhum resultado estético satisfatório. $O$ ator se torturava em cena com um tecido imenso. Aos poucos, o processo psicofísico foi tornando-se mais denso e uma nova imagem se formou.

A imagem de um corpo exausto, agredido, envolto e sufocado por um cordão umbilical se formou em cena. A continuidade deste exercício culminou na imagem simbólica de uma espécie de caverna com poças de água e finalizou na sensação descrita pelo ator de um corpo em água. Estas imagens ocorriam na mente e no corpo do ator, se estruturavam num todo psicofísico.

Como já foi mencionado, Jung (2015) divide o inconsciente em dois níveis, o pessoal e o coletivo.

A camada pessoal termina com as recordações infantis mais remotas; o inconsciente coletivo, porém, contém o tempo pré-infantil, isto é, o resto da vida dos antepassados. As imagens das recordações do inconsciente coletivo são imagens não preenchidas, por serem forma não vividas pelo indivíduo. Quando porém a regressão da energia psíquica ultrapassa o próprio tempo da primeira infância, penetrando nas pegadas ou na herança da vida ancestral, aí despertam os quadros mitológicos: os arquétipos. 


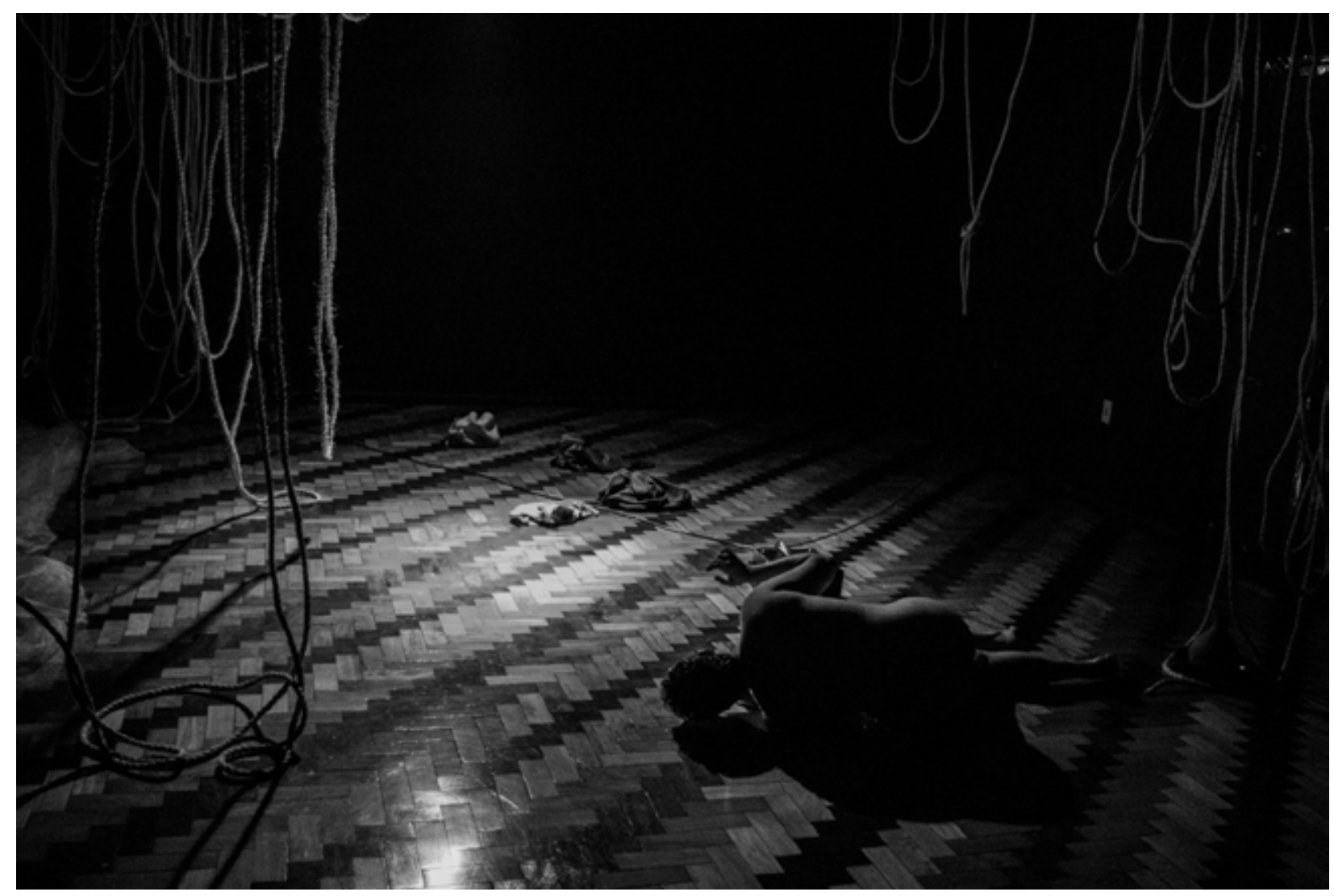

Figura 11 - 0 banho de purificação.

Abre-se então um mundo espiritual interior, de cuja existência nem sequer suspeitávamos (p.54-55).

Com o decorrer dos meses de ensaio, a imagem anteriormente citada assumiu outra dimensão de qualidade numinosa que pode ser notada pelos que presenciaram o ato e abaixo é relatada pelo ator Sebastian Habib:

Começou com a sensação de habitar um grande útero. Apagaram-se momentaneamente todas as conexões com o concreto. Havia apenas ecos e rastros de pensamentos e memórias completamente desordenados e caóticos, como que mergulhados no líquido uterino, dentro de uma placenta. Com acesso restrito, eu não conseguia mais acessá-los quando desejava. Nessa grande luta caí, amorteci e o cansaço me tomou. Deligaram-se várias válvulas. Senti um escuro momentâneo. Quando me levantei a luz me cegava. Não sabia mais o que estava fazendo, onde estava, quem era. A partir de então eu senti que eram esses mesmos ecos e rastros que me acessavam, me tomavam, desordenadamente e no tempo deles. Tornei-me um filtro. Já não ouvia ruídos vindos da rua e do público presente. Abriu-se uma fenda na realidade. Vivi em uma realidade outra, na qual as noções dos movimentos partiam de uma outra lógica temporal. A noção de começo e fim deixou de existir e eu deixei de seguir objetivamente a estrutura de ações proposta. Ao longo do processo senti que deixei de habitar meu corpo, um corpo unificado e centralizado, e me conectei a diversos outros corpos diferentes e não presentes na realidade concreta. Foi como dissipar e descentralizar minhas percepções. Havia um corpo material - meus músculos e ossos-realizando ações e movimentos, mas ele era guiado por diversos outros corpos. Em determinado momento senti uma ruptura ainda maior. Foi como se da dissipação na minha percepção eu conseguisse acessar algo ainda maior, uma consciência superior. Já não havia mais interno e externo. Eu era tudo e todos naquela sala. No momento final, em que era realizado um banho, o contato da água em meu corpo me trouxe um longo, profundo e desesperado choro. E eu entendi tudo. Era o momento de sair do grande útero. Meu renascimento.

\section{3 - CONCLUSÃO}

Após as experiências realizadas, atentei-me para a relação umbilical existente entre a formação do símbolo, a emoção e o afeto, a energia psíquica e a presença. Durante o exercício cênico Cura, eu pude notar, ao final dos ensaios, que em todos os momentos em que percebi a formação de uma imagem mental e deixei-me ser tomado pela mesma, a diretora Mayura Matos percebeu uma modificação na qualidade da presença cênica, assim 
como uma qualidade diferente de concentração. Dadas às devidas proporções, observei os mesmos resultados obtidos no espetáculo Sebastian.

O símbolo é a formulação exterior do arquétipo, a continuidade da imagem arquetípica. Jung (2008) assevera que os arquétipos são a um só tempo, imagem e emoção.

O arquétipo não é apenas a imagem em si, mas, ao mesmo tempo, dinamismo, que se manifesta na numinosidade, na força fascinante da imagem arquetípica. A realização e a assimilação do instinto acontecem [...] não por imersão na esfera instintiva, mas apenas pela assimilação da imagem que ao mesmo tempo também significa e evoca o instinto, mas de forma completamente diferente daquele em que o encontramos no nível biológico [...] ele (o instinto) tem dois aspectos; por um lado, é vivenciado como uma dinâmica fisiológica e, por outro, suas múltiplas formas entram na consciência como imagens e desenvolvem efeitos numinosos que estão ou parecem estar em oposição ao impulso fisiológico [...]. O arquétipo, como imagem do impulso, é psicologicamente uma meta espiritual ao qual insta a natureza do ser humano (JUNG apud JACOBI, 2016, p. 50, grifo do autor).

Nesse entrelaçamento de fisiologia e imaginário encontramos uma qualidade de presença cênica que dialoga com as propostas realizadas por Antonin Artaud, na qual o físico e o espiritual se congregam no exercício cênico. Christopher Innes (1992, p. 70), em seu estudo sobre o teatro sagrado nas vanguardas, traça comentários sobre estas relações nos escritos artaudianos:

Imágenes de energia en el inconsciente y crimen gratuito en la superfície de una presentación teatral evocan, se supone, un estado de espejo en la mente del espectador si se pueden proyectar con la violência necesaria; e este delirio será contagioso, exorcizando las pautas de conducta represiva de la sociedade en conjunto, por su presencia entre el minúsculo porcentaje de la problación que asiste al teatro de Artaud (analogia con la peste que en la confusa metáfora de Artaud es libertad espiritual), causando que todas las formas sociales se desintegren que cunda sin ratas, sin micróbios, sin contacto. La vinculación de lo físico y lo espiritual en esta metáfora es típica del enfoque de Artaud. Hay que imprimir la metafísica en la mente a través de la piel; la dinâmica de la consciencia está encarnada en ritmos escénicos, las armonías lineales de un cuadro afectan directamente al cérebro.

Nos experimentos realizados em sala de ensaio, percebeu-se que o corpo quando em estado de transe, no qual alcance qualidades profundas de concentração, adquire novas variedades de tônus, ritmos e movimentos, ao mesmo tempo em que ocasiona uma forte onda emocional e numinosa expressando-se como afeto. Acredito que esta seja a dimensão arquetípica do trabalho e nas vezes que esta foi alcançada, estabeleceu com os envolvidos no ato um circuito de comunicação irracional, na qual a comunicação se dava por via inconsciente.

Na psicologia junguiana há o que se denomina infecção psíquica. Nesta infecção há uma ligação real entre aquele que se revela e aquele que observa. Quando "as portas estiverem abertas, duas psiques estarão fluindo juntas. Poder-se-á falar num "encontro de almas"'" (HILLMAN, 1984, p. 19). A presença neste caso afastasse do corpo em movimento e variação energética e ocorre na dimensão inconsciente e arcaica acessada no encontro desnudado de dois seres.

Nesta infecção psíquica encontramos um tanto da asseveração grotowskiana de que o "a coisa mais importante é o encontro" (GROTOWSKI, 2011, p. 43). E que este encontro "resulta de uma fascinação. Ele implica uma luta, e também algo tão semelhante em profundidade que existe uma identificação entre os que tomam parte no encontro" (GROTOWSKI, 2011, p. 45).

\section{REFERÊNCIAS BIBLIOGRÁFICAS}

BACHELARD, Gaston. A água e os sonhos. Tradução: Antônio de Pádua Danesi. São Paulo: Martins Fontes, 1989.

BACHELARD, Gaston. A poética do devaneio. Tradução: Antônio de Pádua Danesi. São Paulo: Martins Fontes, 1988.

BAIOCCHI, Maura. Butoh: dança veredas d'alma. São Paulo: Palas Athenas, 1995.

BOECHAT, Walter. A mitopoese da psique: mito e individuação. Petrópolis: Vozes, 2008.

BARBA, Eugenio. A terra de cinzas e diamantes: minha aprendizagem na Polônia. Tradução: Patrícia Furtado de Mendonça. São Paulo: Perspectiva, 2006.

CAMPBELL, Joseph; MOYERS, Bill. o poder do mito. Tradução: Carlos Felipe Moisés. São Paulo: Palas Athenas, 1990. 
CUESTA, Jairo; SLOWIAK, James. Jerzy Grotowski. Tradução: Julia Barros. São Paulo: É Realizações, 2013.

COHEN, Renato. Work in progress na cena contemporânea: criação, encenação e recepção. São Paulo: Perspectiva, 1998.

DORST, Brigitte. Introdução. In JUNG, Carl Gustav. Espiritualidade e transcendência. Seleção e edição: Brigitte Dorst. Tradução da introdução: Nélio Schneider. Petrópolis: Vozes, 2015.

EDINGER, Edward F. Anatomia da psique: 0 simbolismo alquímico na psicoterapia. Tradução: Adail Ubirajara Sobral e Maria Stela Gonçalves. São Paulo: Cultrix, 2006.

ELIADE, Mircea. O Sagrado e o Profano. Tradução de PolaCivelli. São Paulo: Perspectiva, 2016.

FEINSTEIN, David; KRIPPNER; Stanley. Mitologia Pessoal: a psicologia evolutiva do self. Tradução: Teresinha Batista Santos. São Paulo: Cultrix, 1997.

FLASZEN, Ludwik; POLLASTRELLI, Carla (Orgs.). o Teatro Laboratório de Jerzy Grotowski 1959

- 1969. Tradução: Berenice Raulino. São Paulo: Perspectiva; Pontedera, IT: Fondazione Pontedera Teatro, 2011.

FRANZ, Marie-Louise von. Adivinhação e sincronicidade: a psicologia da probalidade significativa. Tradução: Álvaro Cabral. São Paulo: Cultrix, 1993.

GROTOWSKI, Jerzy. Para um teatro pobre. Tradução: Ivan Chagas. Brasília: Perspectiva; Pontedera, IT: Fondazione Pontedera Teatro, 2010.

HILLMAN, James. Uma busca interior em psicologia e religião. Tradução: Aracéli Martins Elman. São Paulo: Paulus, 1984.

HOLLIS, James. Mitologemas: encarnação do mundo invisível. São Paulo: Paulus, 2005.

INNES, Christopher. El teatro sagrado: el ritual y lavanguardia. Traducción: Juan José Utrilla. Cidade do México, MX: Fondo de cultura económica, 1992.

JACOBI, Jolande. Complexo, arquétipo e símbolo na psicologia de C. G. Jung. Tradução: Milton Camargo Mota. Petrópolis: Vozes, 2016.

JUNG, Carl G. A energia psíquica. Tradução:
Mateus Ramalho Rocha. Petrópolis: Vozes, 2015.

A natureza da psique. Tradução: Maria Luíza Appy. Petrópolis: Vozes, 2000a.

. Espiritualidade e transcendência.

Seleção e edição: Brigitte Dorst. Tradução da introdução: Nélio Schneider. Petrópolis: Vozes, 2015

. 0 espírito na arte e na cinência.

Tradução: Maria de Morais Barros. Petrópolis: Vozes, 2013b.

o homem e seus símbolos.

Tradução: Maria Lúcia Pinho. Rio de Janeiro: Nova Fronteira, 2008.

Os arquétipos e 0 inconsciente coletivo. Tradução: Maria Luíza Appy e Dora Mariana R. Ferreira da Silva. Petrópolis: Vozes, 2000b.

Psicologia e alquimia. Tradução:

Dora Mariana R. Ferreira da Silva. Petrópolis: Vozes, 2012a.

Psicologia e religião. Tradução: Matheus Ramalho Rocha. Petrópolis: Vozes, 2012b.

Sincronicidade. Tradução: Matheus Ramalho Rocha. Petrópolis: Vozes, 2014.

KAST, Verena. Sísifo: Vida, morte e renascimento através do arquétipo da repetição infinita. Tradução: Erlon José Paschoal. São Paulo: Cultrix, 2017.

LYRA, Luciana. Guerreiras e heroínas em processo: da artetnografia à metodologia em Artes Cênicas. 2010. Tese (Doutorado em Artes), Instituto de Artes, Universidade Estadual de Campinas (UNICAMP): Campinas-SP, 2011.

Mito Rasgado: Performance e cavalo marinho na cena in process. 2005. Dissertação (Mestrado em Artes). Instituto de Artes, UniversidadeEstadual de Campinas (UNICAMP): Campinas-SP, 2005.

MARTINS, Leda. Performances da oralitura: corpo, lugar da memória. Letras. Santa Maria, $n$. 26, p. 63-81, Jun., 2003.

MAUSS, Marcel. HUBERT, Henri. Sobre o sacrifício. São Paulo: Cosac Naify, 2005. 
MOTTA LIMA, Tatiana. Palavras praticadas: 0 percurso artístico de Jerzy Grotowski, 1959 1974. São Paulo: Perspectiva, 2012.

. Cantem, pode acontecer alguma

coisa": em torno dos cantos e do cantar nas investigações do Workcenterof Jerzy Grotowski and Thomas Richards. Revista Brasileira de Estudos da Presença. Porto Alegre, V. 3, n. 1, p. 220-240, Jan./Abr., 2013.

NUNES, Alexandre Silvia. Ator, sator, satori: Labor e torpor na arte de personificar. Goiania: Editora UFG, 2012.

Dioniso como método: teatro, mito e ritual no espetáculo NJILAS: Dance e Esqueça suas Dores. Urdimento. Florianópolis, V.2, n.27, p.21-35, Dez., 2016.

OTTO, Rudolf. 0 sagrado: os aspectos irracionais na noção do divino e sua relação com o racional. Tradução: Walter O. Schlupp. São Leopoldo: Sinodal/EST; Petrópolis: Vozes, 2007.

SALOMÃO, Eduardo Rizzatti. Exército encantado de São Sebastião: um estudo sobre a reelaboração do mito sebastianista na guerra do contestado (1912-1916). 2008. Dissertação (Mestrado em História Social), Universidade de Brasília: Brasília, 2008.

WINCKEL, Erna van de. Do inconsciente a Deus. Tradução: Benôni Lemos. São Paulo: Paulinas, 1985.

WURZBA, Lilian. A dança da alma: a dança e o sagrado, um gesto no caminho da individuação. In ZIMMERMANN, Elizabeth (Org.). Corpo e Individuação. Petrópolis: Vozes, 2011.

\section{SOBRE O AUTOR}

Saulo Vinícius Almeida é ator e diretor teatral, mestrando em Artes Cênicas (Pedagogia do Teatro - Formação do Artista Teatral) pela USP com o projeto "A experiência numinosa nas práticas formativas do ator". É graduado em Teatro UFRGS, onde atuou como bolsista no projeto "Percursos do drama brasileiro: narrativas, mitos e performances teatrais, de folguedos e reisados, na formação da dramaturgia", no qual estudou ao longo de três anos as relações entre mitologia, psique e a práxis cênica. Integra o Grupo de Estudos em Estética Contemporânea coordenado pelo prof. Dr. Ricardo Fabbrini, locado no Departamento de Filosofia da USP e é colaborador do LAt! - Laboratório de Atuação, coordenado pela Prof( Dr ( Alice Kiyomi Yagyu e locado na Escola de Comunicações e Artes da USP. Durante sua formação como artista-pesquisadorpedagogo, frequentou o bacharelado em Teatro (Interpretação Teatral) da UFMG. Seu interesse atual se encontra na zona fronteiriça entre a experiência do poético e a experiência do sagrado. 


\title{
NAS PEGADAS DO CARVÃO: PERFORMANDO UMA \\ PAISAGEM DE CONTAMINAÇÃO AMBIENTAL
}

\author{
ON COAL FOOTPRINTS: PERFORMING AN
}

ENVIRONMENTALY DEGRADED LANDSCAPE

\section{Ruy Cézar Campos Figueiredo \\ UERJ}

\section{Resumo}

O presente artigo discute a abordagem poética da pesquisa / performance / videoinstalação Carvão Para Seus Olhos Tocarem em relação à paisagem, ressaltando estratégias para lidar com uma questão de contaminação ambiental que acontece nos fluxos de capital e materialidades entre o norte da Colômbia e o Ceará, no nordeste brasileiro. Refletese sobre como se tomar vantagem das possibilidades postas pela performance como pesquisa e sua possível relação com tecnologias audiovisuais para dimensionar e promover o contato com paisagens marcadas por questões ambientais envolvendo tanto ambientes quanto pessoas em meio a processos de deslocamento e contaminação.

\section{Palavras-chave:}

Performance; Paisagem; Meio-ambiente.

\section{INTRODUÇÃO}

Busca-se, no presente artigo, pensar estratégias e abordagens relacionadas à performance da paisagem, explorada em um processo específico de pesquisa e criação em artes envolvendo ação ao vivo com videoinstalação e que teve como eixo temático fluxos situados de contaminação ambiental causada por carvão mineral, desde seu lugar de extração e origem no caribe colombiano até o nordeste brasileiro, onde a matéria alimenta uma siderúrgica e uma termelétrica.

A pesquisa, cuja série resultante se chama Carvão Para Seus Olhos Tocarem ${ }^{1}$, se deu a partir de um direcionamento à materialidade do carvão mineral com a qual passei a me relacionar conforme fui me envolvendo com sua presença no Pecém, anteriormente um distrito de pescadores e casas de

\section{Abstract}

This paper discusses the poetical approach on research / performance / videoinstallation the work Coal For Your Eyes to Touch has in relation to landscape, highlighting strategies to deal with a matter of environmental contamination happening in the flows of capital and materiality between the state of La Guajira, north Colombia and the state of Ceara, northeast Brazil. It is reflected how to take advantage of possibilities posed by performance as research and its possible relation with audiovisual technologies to dimension and promote contact with landscapes marked by environmental matters relating to environments and people living processes of displacement and contamination.

Keywords:

Performance; Landscape; Environment.

veraneio localizado a $50 \mathrm{~km}$ de Fortaleza e atualmente um complexo industrial, palco principal da política de desenvolvimento econômico do Ceará no começo do século XXI. O carvão mineral do Pecém me colocou em contato com a paisagem do lugar, com pessoas que vivem no Assentamento da Parada, e que comigo compartilharam comoventes dramas e narrativas de deslocamento e de poluição ambiental, assim como também me levou à uma residência artística na Colômbia, mais especificamente ao norte do país, lugar de onde é extraído o carvão mineral que no Ceará encontrei e onde pude conviver por alguns dias com uma comunidade da etnia Wayúu², na localidade de La Gran Parada, afetada pela mineração de carvão há mais de 30 anos.

Foram produzidas, até o momento, duas performances: uma tocando na problemática 


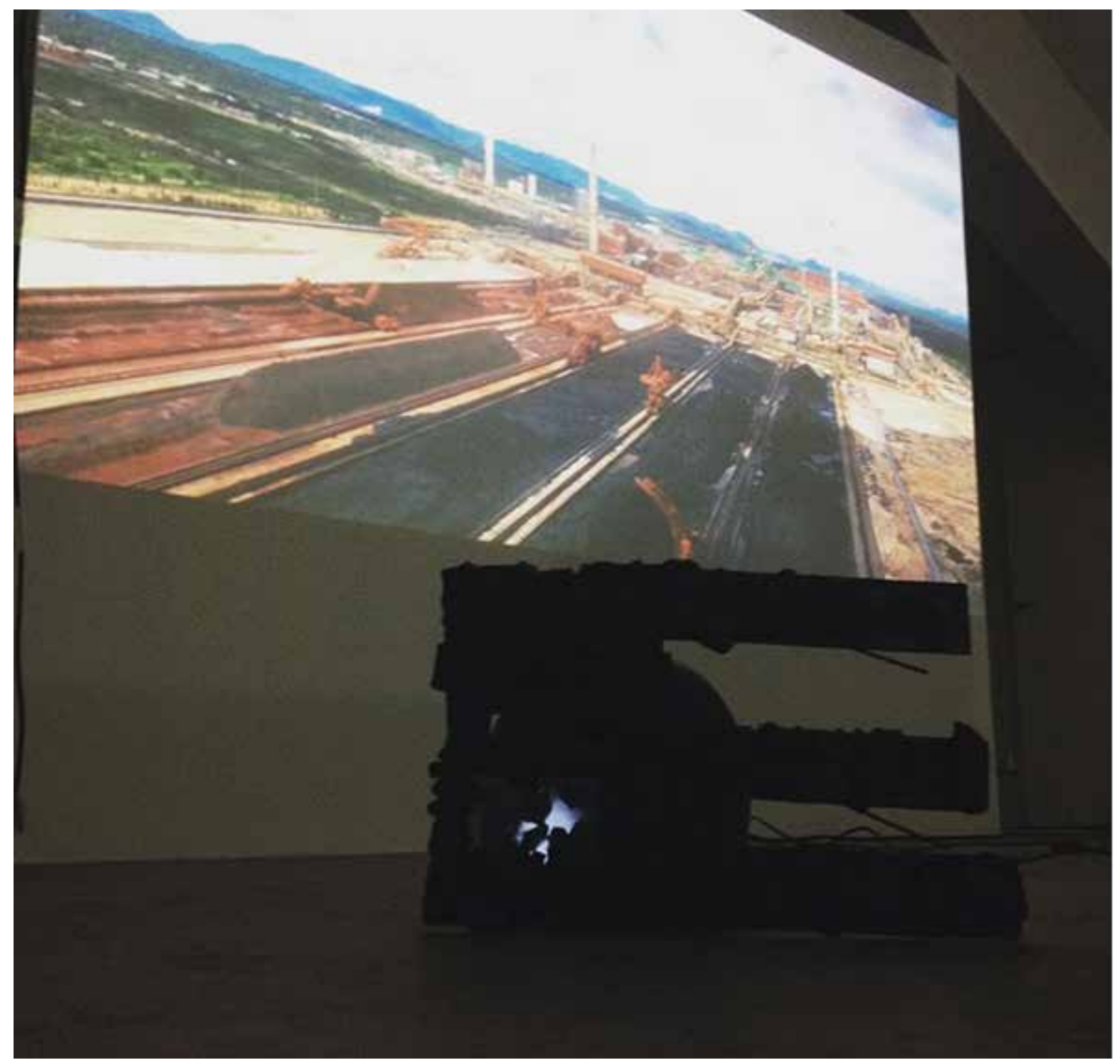

Figura 01 - Projeção de Pátio de Estocagem de Siderúrgica do Pecém e Vídeomáscara de Carvão. Performance/Instalação Carvão Para Seus Olhos Tocarem. Fonte: Arquivo Pessoal.

do carvão para a comunidade brasileira e outra para a comunidade colombiana. Ambas trazem três projeções audiovisuais com vídeos que envolvem imagens da paisagem infraestrutural e industrial relacionada ao carvão e a presença do performer nessas paisagens; uma das projeções traz depoimentos de moradores sobre suas experiências com a poluição relacionada ao carvão; as performances trazem também a presença de uma vídeomáscara feita com carvão coletado na paisagem do Pecém, um vestível feito com o mesmo carvão, uma caixa fotográfica, baião de dois, pratos e um forno elétrico. Um outro elemento especial da performance, em uma de suas apresentações, foi a participação de membros de uma comunidade afetada. Dito isso, compartilho em seguida um link que resume as performances e os vídeos projetados, https:// vimeo.com/249174855, assim como o script das duas ações:

\section{CARVÃO PARA SEUS OLHOS TOCAREM - PECÉM}

1. Assistente dá início às três projeções simultaneamente.

2. Com cerca de meio minuto de iniciadas as projeções, performer entra no espaço segurando a caixa de carvão com fotografias de paisagem, vestindo a vídeomáscara de carvão mineral e o vestível feito de carvão 
3. Performer dá a alguém do público presente no ambiente a caixa fotográfica de carvão, sugerindo que ela circule.

4. Performer permanece em pé por alguns minutos, tremendo seu corpo, corporificando o tremor que a Esteira Transportadora de Minério causa no solo.

5. Performer pega de volta do público parte da caixa fotográfica de carvão, revelando uma quantidade de carvão mineral escondida dentro dela. Performer começa a jogar carvão mineral no chão do espaço expositivo, contaminando-o.

6. Depois que todo o carvão é jogado no chão, performer tira a vídeomáscara e o vestível.

7. Performer dá o vestível para alguém da audiência vestir e sugere que o circule.

8. Então, performer retorna para a vídeomáscara e a retira do seu suporte, dando-a para alguém da audiência segurar e circular.

9. Performer então retorna ao gesto de coletar o carvão mineral na paisagem, fazendo isso com o carvão mineral derramado no chão, varrendo-o e disponibilizando vassouras para que outras pessoas varram junto.

8. Depois que o espaço está novamente limpo, palavras são compartilhadas sobre como a performance específica se relacionou com um momento específico do processo de relação com a comunidade e da própria comunidade em si.

\section{CARVÃO PARA SEUS OLHOS TOCAREM - DESLOCAMENTO BAIÃO DE DOIS}

1. Performer inicia os vídeos das três projeções. O espaço está disposto com a vídeomáscara no chão, assim como o vestível estirado em formato circular com uma panela tampada no seu centro e pratos de plástico nos entremeios. Em um forno elétrico há um pouco de baião. A caixa fotográfica está no chão.

2. Performer inicia uma conversa com o público durante o período em que os vídeos estão apenas com imagens, sem áudio.

3. Quando o áudio se inicia, performer começa a retirar as pedras de carvão que estão no interior da caixa fotográfica e atira pedra por pedra de carvão em cima da tampa da panela.

4. A performance segue se alternando entre momentos de imagens com áudio e imagens sem áudio.

5. Nos intervalos sem áudio, performer conversa com o público.

6. Nos intervalos com áudio, performer permanece, primeiramente, jogando as pedras de carvão em cima da panela.
7. Em um segundo momento, após ter derramado todo o carvão, performer abre a panela e começa a servir para o público, em pratinhos, o baião de dois que estava em seu interior.

Creio que tal projeto se encaixa bem na ênfase que Hjorth et. Al (2016, p. 129) dão em um capítulo de seu livro Screen Ecologies às práticas artísticas que estão emergindo como um reconhecimento crítico dos problemas associados com o desenvolvimento industrial, a intensificação urbana e as questões concomitantes de poluição, contaminação e mudança climática. As autoras apontam práticas que, vistas coletivamente, começam a mapear, através da arte, uma visão ecocrítica e a retratar as formas que o desenvolvimento da região está emaranhado com a natureza e o meio-ambiente (HJORTH et. al, p. 109), demonstrando questões que são transnacionais por entre fluxos globais, regionais e locais.

Interessou-me, particularmente, como o carvão mineral, uma matéria relacionada a esses diversos fluxos de poder, passa a fazer parte das narrativas pessoais sobre os lugares, assim como parte das paisagens desses lugares. Foi especificamente a partir de uma atenção ao carvão mineral e aos seus fluxos na paisagem que se começou a estabelecer, no processo de pesquisa, relações entre lugares distantes como o Ceará, no Brasil, e La Guajira, na Colômbia, pensando-se como que o trabalho artístico poderia estabelecer links entre esses lugares. Também é a partir do aspecto do trabalho relacionado ao carvão mineral que se possibilita deslocar certos aspectos da teoria fílmica e das artes para uma linha ecocrítica que se torna mais relevante conforme nos reconhecemos em uma era em que as intensas alterações geológicas provocadas pela lógica iluminista de progresso teleológico indicam um futuro ambientalmente desastroso para as presentes e futuras gerações de seres vivos, como se pode constatar a partir dos debates em torno do Antropoceno ${ }^{3}$.

\section{ARTE E PERFORMANCE COMO PESQUISA}

Os scripts de ação compartilhados são resultado da relação de toda uma complexidade ecológica com a processualidade formal de uma abordagem artística direcionada à relação entre performance e múltiplas projeções/ecrãs audiovisuais com linguagem cinematográfica. Os desdobramentos poéticos do projeto se pautam pela ação em 


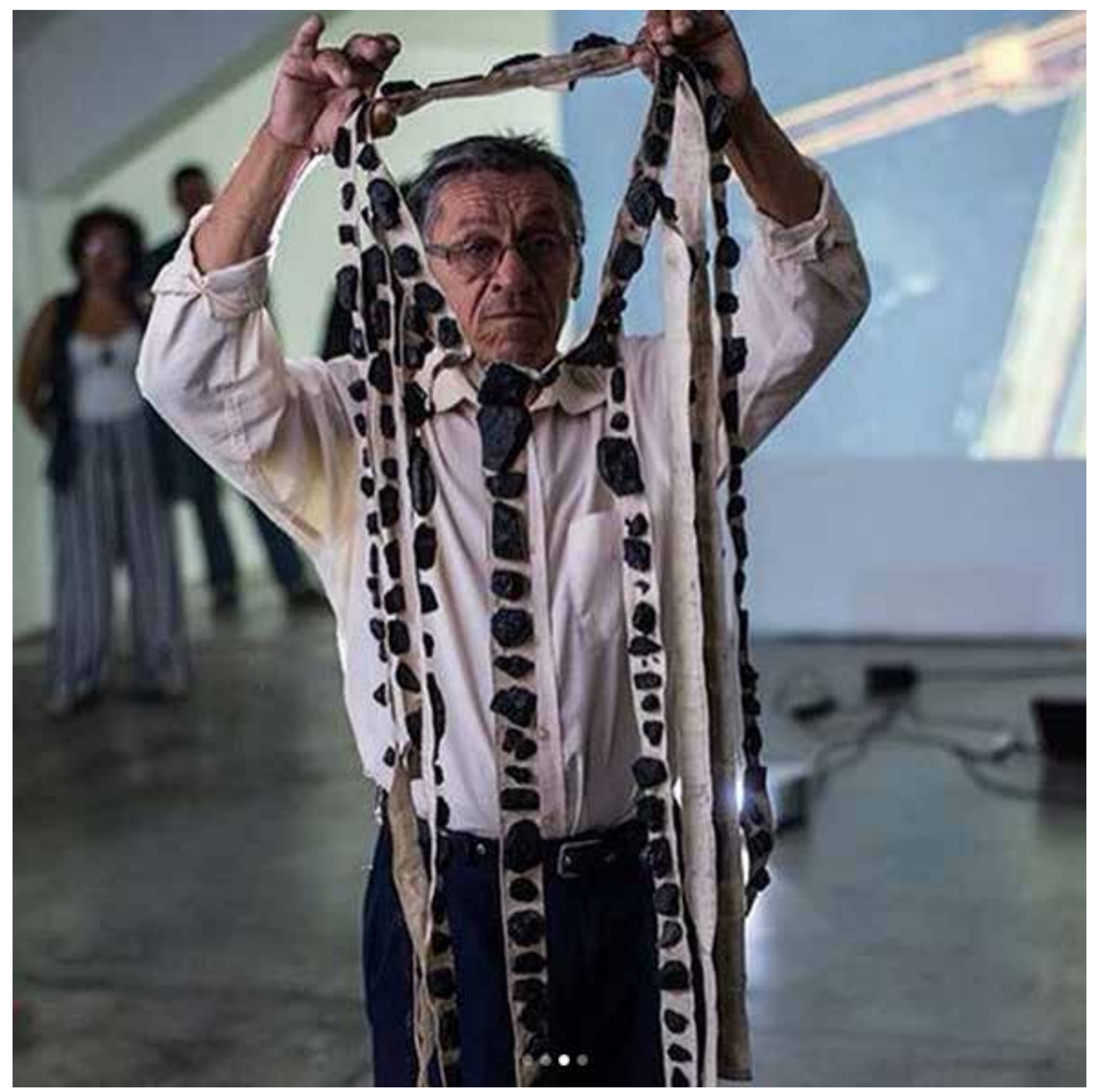

Figura 02 - Morador de comunidade afetada participando da performance com vestível. Performance/Instalação Carvão Para Seus Olhos Tocarem. Fonte: Arquivo Pessoal.

torno de materialidades e tecnologias como drones e videocâmeras registrando a paisagem, ensejando uma forma de apresentação do corpo e da imagem em movimento marcada multiplicidade da atenção e da percepção e, ao mesmo tempo, pela possibilidade de se valorizar as narrativas pessoais de pessoas ambientalmente afetadas por partículas de carvão no ar. Baliza-se de estratégias próprias das possibilidades colocadas pela arte contemporânea para responder ao mundo e a vida, transbordando uma mistura de criação e pensamento para além das fronteiras rígidas e engessadas dos modos de pensar e criar cartesianos e ainda imponentes em muitas áreas da produção acadêmica.

A performance, quando articulada a partir de uma relação fenomenológica com as tecnologias, tem um potencial, pensando a partir de Kozel (2009), de disparar tanto espaços quanto materialidades, provocando uma existência em estado de emergência que evidencia um profundo entrelaçamento entre ficção e realidade, e assim entre ação e atenção, que dilui o binarismo entre pensar e fazer através de uma corporificação dinâmica. 
When we perform we mediate inner and outer. We translate, we regulate, we discover, we get surprised, angry, fearful, hurt, exhilarated. If we create responsive relations with others and our environments that transcend language, then by means of intentional performance with technologies we can regard technologies not as tools, but as filters or membranes for our encounters with others.. (KOZEL, 2009. P. 70)

Compõe-se, ao conspirar possibilidades da arte e performance como pesquisa, um deslocamento da pesquisa acadêmica de uma epistemologia logocêntrica de conhecimento para uma epistemologia que enseja o conhecimento corporificado, espacializado e imagético. Traçamse estratégias que consideram, no geral, a existência de um fluxo de retroalimentação entre sensorialidade, intelectualidade e cognição no processo de pesquisa.

Pesquisar é, antes de tudo, parte integral de se criar um trabalho de arte ou uma performance, ainda que, de acordo com Arlander (2012, p. 183) não se esteja pensando essa criação como pesquisa. A partir da autora, pode-se apontar como elementos de pesquisa estão embutidos na criação de trabalhos de arte ou performance, através da busca por informação, da organização e procura por materiais, da edição, da exploração do espaço ou de circunstâncias relacionadas à lugares específicos, da investigação de recursos técnicos e econômicos, assim como nas possibilidades de colaboração, de treinos e ensaios e no compartilhamento de processos artísticos.

Nesse sentido, tem-se desenvolvido globalmente ações artísticas dentro de um enquadramento de metodologia de pesquisa acadêmica, estabelecendo-se a pesquisa artística e a pesquisa baseada ou conduzida pela prática nas artes criativas e performativas como um campo de metodologia e epistemologia artística em desenvolvimento. As demandas específicas de cada contexto e cada trabalho fazem, ainda, com que cada nova pesquisa, de acordo com Arlander (2012), seja importante como um modelo potencial para futuras pesquisas.

Arlander se fundamenta nas autoras finlandesas Hannula, Suorana e Vaden (2005, p. 160) para reafirmar a pesquisa artística como uma tecelagem, ou uma tapestria que leva em consideração muitos fatores: o que foi lido por quem pesquisa, o que se conhece a partir de sua experiência própria de vida, o que se observa, o que se cria, o que se imagina e o que se delibera, “onde o autor não avança para descrever a realidade mas criar a realidade para o seu trabalho a partir de suas próprias" (HANNULA et. al, 2005, 160; trad. livre).

A citação tem proximidade com o que tem se delineado na abordagem da performance as research, quando, como exemplo, Haseman (2006) afirma que a performance não só é capaz de expressar uma pesquisa, como também que nessa expressão a performance se torna a pesquisa em si, estabelecendo-se a prática como principal atividade de pesquisa, como uma précondição necessária de engajamento de quem pesquisa através de performances.

A pesquisa com performance tem, de acordo com Haseman (2006, p.49), nesse sentido, tanto uma iniciação quanto um empreendimento através da prática, utilizando-se de processos metodológicos práticos, ao mesmo tempo que também são utilizadas estratégias de tradição da pesquisa qualitativa, como prática reflexiva, observação participante, etnografia performativa, etnodrama, investigação biográfica/autobiográfica/narrativa e o ciclo de investigação da pesquisa-ação. (HASEMAN, 2006, p. 49)

Nesse sentido, percebe-se, para o projeto Carvão Para Seus Olhos Tocarem, que tal estratégia se colocou como a mais profícua para se aproximar de fluxos, dinâmicas de deslocamentos em transversalidade, processos delicados socialmente ao mesmo tempo que artisticamente repletos de questões e potências. Tão necessário quanto experienciar processos de criação na paisagem do Pecém para ativar fluxos de relação com o lugar e as pessoas que o habitam, foi também travar contato direto com materialidades, promover que outros também tivessem esse contato, assim como produzir imagens, contaminar imagens, sentir coceira com o carvão, agir no campo da arte, produzir deslocamentos críticos, refletir, provocar e gerar narrativas, colaborar, dispondose sensorialmente e afetando sensorialmente, por fim também buscando por colaborações. Em meio à todas essas ações de ordem variada, delicada, por vezes conflitantes e sem muita tradição escavada, estar atento para a performatividade da pesquisa, 
para além das próprias performances artísticas que foram apresentadas, foi fundamental para perceber a multiplicidade de aspectos lidados sem afundar em um ponto específico da variedade de nuances reflexivas com as quais se trabalhou.

\section{A PROBLEMÁTICA DO CARVÃO NO CEARÁ E NO NORTE DA COLÔMBIA}

O Pecém é um distrito do município de São Gonçalo do Amarante, no Ceará, e é palco de um projeto infraestrutural estratégico para o desenvolvimento do Estado, o Complexo Industrial e Portuário do Pecém - CIPP, que foi criado com o objetivo de reestruturar o parque industrial cearense, contando, conforme projeto inicial, com uma usina siderúrgica, usinas termelétricas, uma refinaria de petróleo, uma unidade de regaseificação de gás natural liquefeito GNL e um centro de tancagem de combustíveis. Sua inauguração ocorreu em 2002, tendo sido decretada uma área de interesse estadual de cerca de $335 \mathrm{~km}^{2} \mathrm{em} 1996$ (Decreto N. ${ }^{\circ}$ 24.032, de 6 de março de 1996), desencadeando desapropriações polêmicas e problemáticas de comunidades inteiras. Envolver-se com a paisagem de tal lugar foi também se envolver com as narrativas que envolvem esses processos de deslocamento e reassentamento, mais especificamente a partir de um foco na comunidade do Assentamento da Parada, que hoje sob a dúvida e a possibilidade de ser deslocada por uma segunda vez devido ao pó de minério e carvão no atual assentamento, onde foram instalados pelo Estado em 2010, conforme o Tapuio, onde viviam, se encontrou sob interesse de construção da Refinaria Premium II da Petrobras.

Relacionar-se com tal comunidade, durante a pesquisa, consistiu em realizar ações de caráter artístico, principalmente produções de vídeo e performances tendo como base um olhar para a materialidade do carvão mineral, que se forma através do acúmulo de matéria vegetal coberta por sedimentos e comprimida com o passar do tempo. As condições de baixo oxigênio resultam na concentração de carbono comprimido com outros componentes de matéria vegetal, como oxigênio, hidrogênio e água. 0 período Carbonífero recebeu tal nome nos estudos geológicos devido às suas condições marcadas pela formação em grande quantidade de carvão em todo o mundo, quando pântanos inteiros foram sedimentados, comprimidos e transformados em matéria, cerca de 350-250 milhões de anos atrás.
O uso, extração e combustão do carvão são prejudiciais ao meio-ambiente, para Bjureby et. al. (2008). Dióxido sulfúrico $\left(\mathrm{SO}^{2}\right)$ e dióxido de nitrogênio $\left(\mathrm{NO}^{2}\right)$ são produzidos em larga escala no seu processo de combustão, assim como o dióxido de carbono $\left(\mathrm{CO}^{2}\right)$, gás que é o maior contribuinte para a mudança climática provocada pelo homem. Na paisagem do Pecém, destaca-se a presença maquínica de uma Esteira Transportadora de Minério de $12 \mathrm{~km}$ cortando as dunas de areia e fazendo vizinhança com comunidades.

Frequentei o lugar enquanto artista-pesquisador buscando sentir a paisagem, circulando por lugares do distrito e me relacionando com as presenças maquínicas que atravessam dunas, vegetação, vidas humanas e animais, lagoas. Também busquei o contato direto com o carvão mineral e suas partículas no ar e no solo. Esses esforços de estar no ambiente estiveram mediados, não continuamente, pelo uso de uma câmera DSLR, que, a princípio, foi utilizada para o registro fotográfico e, apenas depois, para registros videográficos.

Diante de tudo o que havia lido sobre carvão mineral e sua presença, sentia a necessidade de o encontrar e coletar, ainda que não soubesse exatamente o que faria com ele a princípio. Percorri, assim, diferentes pontos do distrito industrial para ter uma experiência com o lugar e sua paisagem, bastante direcionado então à presença maquínica da Esteira Transportadora de Minério. A Esteira possui uma estrada de terra acompanhando seu percurso, que se encontrava sem avisos de restrição ao acesso, quando comecei a frequentar a região. Ao adentrar nessa estrada, produzi fotografias, observei o entorno, subi nas dunas, assim como coletei pedras de carvão que estavam misturadas com a areia. Acabei sendo surpreendido, depois de um tempo, pela presença de seguranças privados que me avisaram, respeitosa, ainda que tensamente, da impossibilidade de que eu permanecesse ali.

Através de documentos da MPX (2011), que detinha inicialmente maior parte do capital da siderúrgica, descobri uma dimensão geográfica maior dos problemas relacionados ao processo da extração e do transporte do carvão mineral no Pecém, especificamente ao tomar conhecimento de o caribe colombiano era o ponto de embarque 


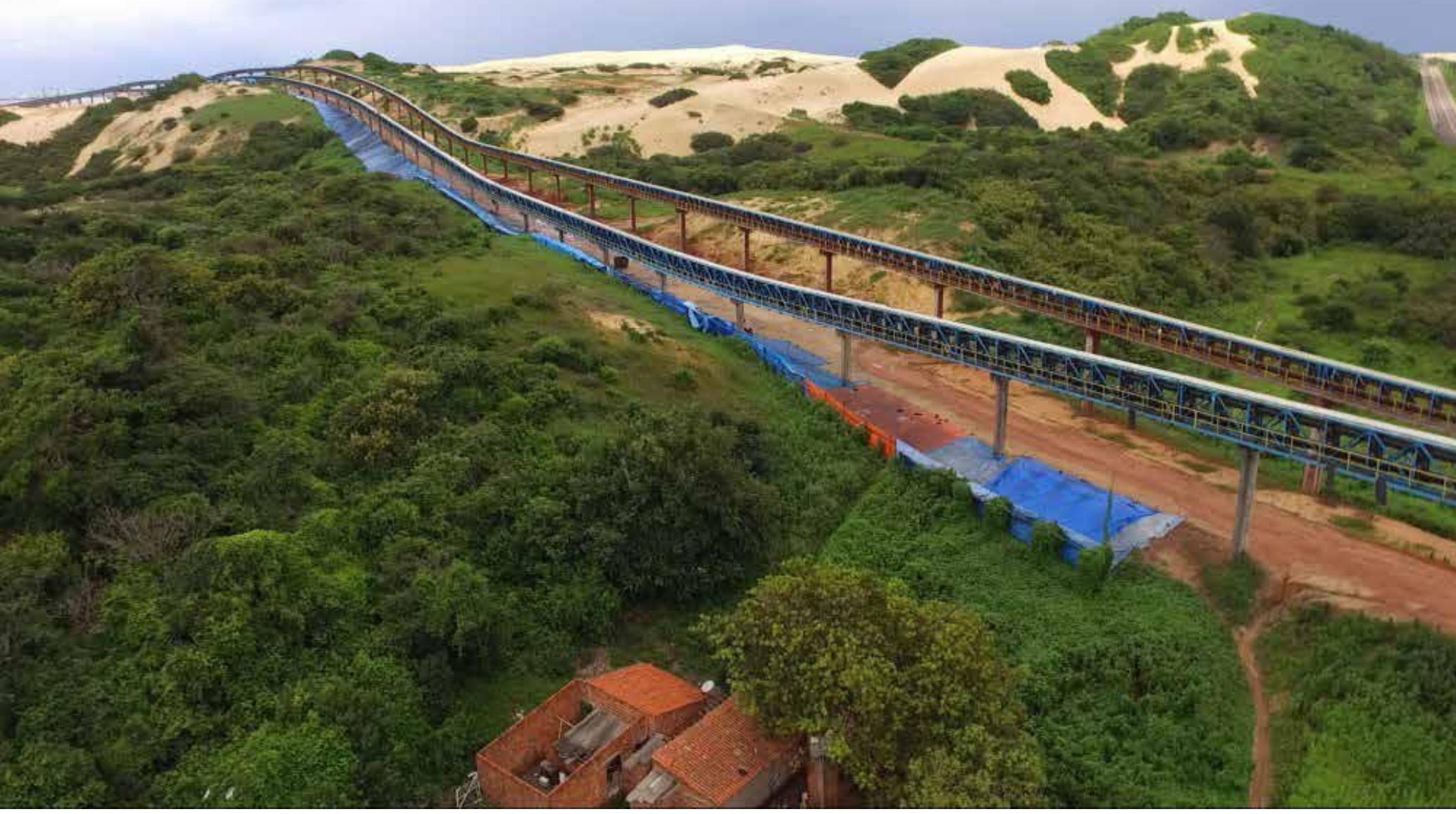

Figura 03 - Esteira Transportadora de Minério. Fonte: Arquivo Pessoal.

do carvão que chegava ao Ceará. A região é marcada por uma forte tradição indígena e uma histórica presença de guerrilheiros, assim como também atual palco de projeção e execução, de acordo com Becerra (2009), de uma série de megaprojetos de desenvolvimento industrial relacionados a interesses pelo desenvolvimento de infraestrutura viária, portuária, energética e de exploração de carvão.

Estos proyectos implican en la práctica un ordenamiento territorial, social, político y económico que se superpone a los ordenamientos ancestrales, generando cambios bruscos y negativos sobre todos los espacios y ámbitos relacionados con el territorio, afectando de manera directa y profunda la supervivencia de los pueblos indígenas. Los mega-proyectos, además de tener serias repercusiones ambientales, desconocen la existencia de sitios sagrados, los destruyen o se construyen sobre ellos, afectando los procesos culturales y sociales de los pueblos indígenas, atentando contra las posibilidades de permanencia de su cultura y transmisión del conocimiento tradicional, y constituyendo, en suma, un modelo de violación de los derechos territoriales y de la autonomía, en franco desconocimiento de la relación ancestral que tienen los grupos étnicos con sus territorios (BECERRA, 2009)
O único país da América Latina a figurar entre os 10 maiores produtores de carvão do mundo é a Colômbia, que em 2014, 88,5 milhões de toneladas boa parte dessa para exportação. Os efeitos sentidos pela população que toma contato com o carvão através da atmosfera contaminada lá são semelhantes aos do Ceará: coceiras, doenças de pele, problemas respiratórios, deslocamentos forçados. A intensidade dos problemas lá, todavia, é maior, e se expressa em campanhas como a atual \#DevuelvanEIRio, que demanda a devolução do Rio Rancheria ao seu curso natural, após ele ter sido desviado para passar na área de uma mina de produção de carvão (PALOMINO, 2016).

Na semana que passei em uma região mineira, tive a oportunidade de conhecer tal rio, assim como percorrer e produzir imagens de uma região afetada pela extração e transporte do carvão mineral. Conversando com pessoas das comunidades, dimensionei como a vida de toda a região é marcada pela convivência e vizinhança com a infraestrutura do carvão mineral e que isso geralmente implica conflitos em torno da terra, da saúde e da própria narrativa do lugar. 
Todas essas informações foram se tornando importantes para meu processo de pesquisa conforme encarava o carvão mineral que havia trazido para casa, assim como passei a frequentar semanalmente o Pecém, para me relacionar, primeiramente, com sua paisagem, antes de buscar me aprofundar em relações com pessoas que vivenciam cotidianamente tais problemas. Interessava-me lidar com a paisagem me questionando sobre as possibilidades de a performar, especificamente refletindo sobre o que ensejaria a performance dessa paisagem. Depois, foi surgindo a possibilidade e o interesse de se relacionar essa paisagem no Brasil com a paisagem da Colômbia, ambas conectadas pela mesma matéria, com a qual passei a produzir objetos de caráter relacionais.

\section{PERFORMANDO A PAISAGEM: AMBIENTE, NATUREZA E CULTURA}

Aproximei-me de uma concepção de paisagem estando envolvido por um interesse por questões que envolvem tatilidade e pele em relação à imagem em movimento (ELSAESSER, 2015), assim como por um direcionamento à performance, ainda mais a performance pensada como um recurso epistemológico e metodológico. O resultado foi uma busca por se ter um contato com a paisagem indo além da abordagem tradicional de paisagem, pautada na visão distanciadora e no binarismo entre natureza e cultura. Arlander (2012) coloca como sendo um legado do modernismo e do "esclarecimento" a influência da oposição entre natureza e cultura sobre outros binarismos como artista e paisagem, performer e ambiente, estabelecendo oposições que não se sustentam diante da vida vivida.

Quando as membranas de plantas e dos pulmões humanos do Pecém se encontram com pó de carvão advindo de La Guajira, ou quando um rio nesse estado colombiano, o rio Rancheria, é desviado de seu curso para passar mais proximamente de uma mina, ou quando experienciamos os efeitos do aquecimento global em nosso cotidiano, a divisão entre cultura e natureza e pessoa e paisagem se encontra com uma entre várias das suas limitações. As paisagens devem ser percebidas não como circunscritas em uma entidade abstrata com a qual nos relacionamos à distância, constituindo-se tais, na verdade, como uma ecologia na qual somos parte e com a qual temos um relacionamento mútuo, em um caráter perceptivo e mais processual (HJORTH et. Al, 2016). Considerando tal contexto, Arlander elabora uma série de perguntas que mobilizam uma percepção da paisagem corporificada, epistemológica e relacional:

Como se vive em, sobre e através das paisagens?

Como estão a paisagem e o ambiente revelados, imaginados, experienciados, contestados, animados e apresentados por, em e através da performance?

Como pode a performance informar, estender e aprimorar a interpretação, a apreciação e o engajamento com a paisagem e o ambiente?

Como as performances podem iluminar, explicar e problematizar a multiplicidade de anexos, significados e emoções que ressoam dentro e desde as paisagens: visual, aural, tátil?

Quais estratégias e formas de exposição de performance são inspiradas e necessárias ao se trabalhar com a performance como meio e cena para expressão?

Qual é a vida da paisagem e como ela é performada? (ARLANDER, 2012, P.15; trad. livre)

As respostas que a autora vai buscar para tais questões são bastante interessantes para 0 que se buscou através do processo Carvão Para Seus Olhos Tocarem, especialmente porque tais respostas entrecruzam discussões em torno da relação entre performance e vídeo, performance e instalação, performance e imagem em movimento com múltiplos-ecrãs, estando a artistapesquisadora sempre interessada em evidenciar potenciais caminhos metodológicos para quem está pesquisando, especificamente para quem está interessado em pesquisar paisagens, posicionando quem pesquisa em uma relação de mistura com seu objeto, método e os resultados.

Nesse sentido, a autora aponta estratégias para performar a paisagem que buscam lidar com tais questões, dilemas e que se abrem para recursos performativos, instalativos e imagéticos. Especificamente na relação entre instalação e performance, Arlander reconhece uma potencialidade de aproximações que the foram cabíveis em seus processos de busca por performar a paisagem. Ela aponta, a partir de Kwon (2002), como transformações das artes nos anos 1960 excederam as limitações das mídias tradicionais, suas configurações institucionais, 
realocando o significado de dentro do objeto de arte para o seu contexto e enfatizando a experiência vivida corporalmente, fenomenologicamente, dos trabalhos de arte, aproximando em vários aspectos instalação de performance através das relações de lugar e espaço:

Uma performance ao vivo toma lugar como um espaço. Uma performance toma lugar em um lugar, geralmente falando de outros lugares, mas, acima de tudo, ela cria um espaço, uma situação ou um mundo. Um relacionamento espacial inevitavelmente surge entre o performer e o espectador. Uma performance ao vivo se realiza como um espaço. E quanto a videoinstalação? Uma instalação acontece como um espaço, ocorre em um lugar e pode também falar de outros lugares. Uma instalação, também, necessita que os espectadores visitem o lugar por eles mesmos. Em vez de um relacionamento entre performers e espectadores, em uma instalação um relacionamento surge entre o visitante e o que está sendo performado ou posto em display.. (ARLANDER, 2012, P.71; trad. livre)

A partir dessa compreensão de possibilidades de relação entre instalação, vídeo e performance, desde o espaço, ela irá estabelecer algumas possibilidades de busca por fusão com a paisagem por meio da redução da diferença entre o performer e a paisagem invocando relações de movimento ou forma e cor, assim como se performando a paisagem ao se destacar dela, utilizando-se do contraste para mostrar seus aspectos.

Quando se olha para a paisagem, quem está pesquisando e performando pode funcionar, enquanto elemento dessa paisagem, como um condutor da experiência perceptiva em vez de como um mero impedimento ou uma pretensa ausência. A autora dá atenção à qualidade da presença na paisagem, à sua experiência do ambiente, assim como a forma a qual essa presença e essa experiência se transpõem na produção de imagens videográficas, questionando, por exemplo:

pode a imagem de um vídeo expressar a diferença quando comparada com uma imagem fotográfica? Não é uma imagem de vídeo como uma foto, algo que se olha para em vez de algo que se engaja fisicamente com? E o que é estar em uma imagem? É a paisagem sem uma figura humana realmente 'vazia', sem significado? Vai a figura humana necessariamente virar a coisa principal, enquanto a paisagem recua ao seu papel de suplemento ou background? Pode o corpo humano funcionar como um 'condutor' em vez de um impedimento quando se está olhando para a paisagem? (ARLANDER, 2012, P. 137; trad. livre)
As questões surgem, em relação ao vídeo, pelo fato de que, para Arlander, essa mídia aparentemente mantém a tradição de representação da paisagem em pinturas e fotografias, ao depender de um enquadramento da visão, ainda que possua a possibilidade de movimento como um recurso de diferenciação em relação às mídias prévios. Para ela, todavia, o caráter temporal do vídeo mostra a paisagem como um processo e a figura humana como uma paisagem corpórea. Essa figura humana, quando pensada a partir de uma possibilidade performativa em relação à paisagem, direciona questões vinculadas à relação entre performance e, com e como ambiente. Realizar performance "como" algo ou "com" algo na paisagem, reconhecendo uma agência desse algo na constituição da experiência perceptiva, na performance da paisagem. A artista-pesquisadora busca por alternativas à possibilidade de que a paisagem, na sua performance, funcione apenas como plano de fundo ou cenário para a figura humana. Ela escolhe, dessa maneira, elementos específicos na paisagem para trabalhar com eles, para performar em um sentido de co-existência, e o faz, por exemplo, com árvores.

Ela aponta então três modos de uso de elementos da paisagem que encontrou para estabelecer relações: o elemento como suporte, como coperformer e como abrigo. No caso da árvore, seu uso como balanço seria exemplo de seu uso como suporte. 0 gesto de se sentar ao lado dela, ou de se fazer sombra dela, seria o gesto de co-performar. Esconder-se embaixo dela, por exemplo, estaria relacionado ao gesto de se abrigar.

Falar de borrar da fronteira entre performer e ambiente significa assim borrar a fronteira entre performer e suporte, performer e coperformer ou performer e abrigo. Isso é relevante principalmente do ponto de vista do espectador. Como performer eu posso experienciar algum tipo de interconectibilidade com o meu ambiente e imaginar um tipo de existência compartilhada com a árvore, mas eu certamente sei qual a fronteira entre a árvore e eu, não há dissolução real tomando lugar do meu ponto de vista. A mistura é uma construção semi-ficcional produzida em vídeo. (ARLANDER, 2012, p. 250; trad. livre)

0 elemento da paisagem que marcou o interesse da pesquisa aqui posta foi o carvão mineral e as presenças maquínicas que a ele estão relacionadas. O caráter semi-ficcional desses gestos de fusão com tal elemento e sua presença 


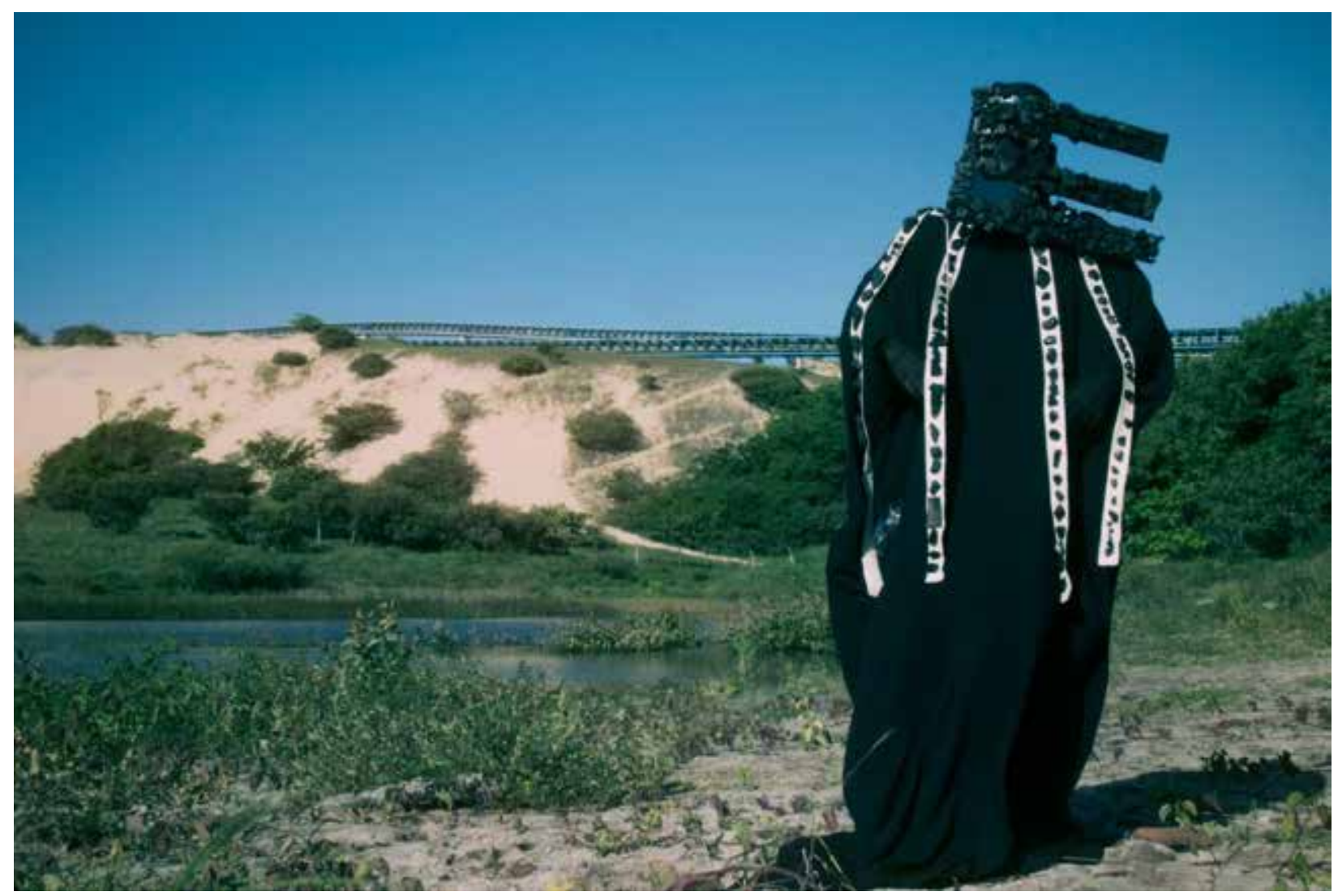

Figura 04 - Still de Vídeoperformance. Performance/Instalação Carvão Para Seus Olhos Tocarem. Fonte: Arquivo Pessoal.

na paisagem, essa mistura e co-performatividade com a matéria, foram do interesse central para o desenvolvimento do projeto, determinando um modo de engajamento e relação com a paisagem, assim como estratégias de promoção do contato com tal materialidade e a paisagem do Pecém para pessoas que viessem a lidar com o projeto, seja através de uma vídeo-máscara performada com imagens das paisagens, ações ao vivo envolvidas por múltiplas projeções ou fragmentos de carvão mineral coletados, derramados agressivamente no espaço expositivo, ou misturados com baião.

A materialidade do carvão utilizado nas performances tem uma performatividade peculiar, conforme sua trajetória é realçada desde seu início na Colômbia, passa pelo Pecém, parando no espaço performativo e de arte enquanto máscara e vestimenta, além de em detritos que se relacionam com comida (o baião de dois) e com a mão de uma diversidade de espectadores que podem experienciar, além de diferentes modos de contato com a matéria, imagens das paisagens maquínicas desses dois lugares, assim como a narrativa das pessoas que nelas vivem.
Destaco, aqui, o processo de performance da paisagem em relação a produção da vídeomáscara, ou seja, uma máscara de carvão mineral com um dispositivo móvel multimídia acoplado com um vídeo em loop. No vídeo estão contidas imagens da paisagem industrial e infraestrutural da região. A máscara foi o primeiro gesto de criação do processo e o carvão mineral que coletei para a fazer me colocou em contato com a paisagem do lugar. Nesse sentido, escolher utilizar o carvão mineral coletado como superfície para a máscara, assim como me inspirar na paisagem industrial do Pecém para pensar a sua forma, foram estratégias que fizeram com que sentisse, ao decidir novamente por performar com máscaras, que estava trazendo novas questões para desdobrar meu processo e interesse de relação entre vídeo e máscara.

O desenho da máscara tomou como inspiração as chaminés de uma termelétrica que consome parte do carvão que chega no Pecém. Daí também se projetou para que dessa máscara saísse fumaça, reproduzindo de alguma maneira a impressão de 
se olhar para uma paisagem industrial, e o fazer mediado pela própria materialidade do carvão que deveria ter sido queimado e circulado na atmosfera do lugar, mas que por uma série de processos de degradação ambiental e de arte acabou por vir parar em uma máscara, na frente do meu rosto, manipulada pela mão de pessoas que vieram a ter contato com a matéria através desse dispositivo, pois circulava pelas mãos das pessoas nas performances.

O primeiro efeito que pude sentir, ao começar, em meu estúdio doméstico, a trabalhar com o carvão mineral que coletei foi a coceira. Não apenas eu, como outras pessoas que comigo conviveram enquanto trabalhei diretamente com o carvão, fragmentando-o e o colando em uma superfície elaborada para a máscara, reclamaram de sentir suas peles serem provocadas ao gesto de coçar. Assim como nós, tanto as pessoas no Ceará quanto as pessoas no norte da Colômbia, que vivem problemas ambientais relacionados ao pó de carvão na atmosfera, também reclamam de coceira.

De acordo com Tallis (2013), a coceira é filosoficamente problemática pela dificuldade que ela cria de ser localizada: na perna que coça, por exemplo, ou no cérebro de quem a sente, ou em um modelo mental construído pelo cérebro, ou "no habitante de uma substância cartesiana pensante" (TALLIS, 2013, trad. livre). As sensações como a coceira são diferentes do pensamento, “onde o espaço da psicologia está casado com o espaço da lógica e da semântica - do significado e da referência" (TALLIS, 2013, trad. livre), provocando a conclusão do filósofo de que a sensação de coceira está antes onde ela é sentida, na pele, não no cérebro ou em um modelo do corpo criado por ele. Foi a partir dessa coceira que senti ao jogar com a máscara enquanto um aparato técnico, então, que comecei a buscar por um título que insinuasse uma coceira, insinuasse que a sensação do carvão está corporificada no olho tátil de quem viesse a ter contato com as experiências perceptivas que iria propor sobre o tema no contexto da pesquisa.

A busca por situar teoricamente a máscara partiu então desse processo que envolveu sentir coceira, pensar a partir da pele, do corpo e do contato desse corpo com uma paisagem ecologicamente afetada por poluição.
Exemplificando através desse objeto audiovisual máscara, creio que a especificidade com a qual trabalho aqui proporciona um outro peso para as questões relacionadas com performance da paisagem, visto que trata-se de uma situação onde uma problemática de poluição ambiental se faz presente e se busca elementos materiais dessa poluição para se estabelecer relações de co-performance, suporte ou "abrigo" e até mesmo alimento indigesto, com a incorporação do baião de dois.

\section{CONCLUSÃO}

Partículas poluentes pouco perceptíveis ao olho circulam na atmosfera de um dado ambiente. Ainda assim, essas partículas estão presentes e podem ser percebidas: as infraestruturas que a disseminam cortam a paisagem de lugares como La Guajira ou o Ceará. Um baião de dois pode ser considerado efetivamente um elemento de performance da paisagem? A mistura do baião com partículas de carvão corporifica o cruzamento da vida em paisagens que careciam narrativas de conexão. Não se vive sem arroz e feijão, pelo menos no Ceará e no norte da Colômbia. Essa mistura se dá em um espaço habitado por uma multiplicidade de projeções audiovisuais dessas paisagens e de depoimentos de pessoas que vivem nessas paisagens. As questões levantadas por Arlander sobre como performar a paisagem incorporam em si um interesse pela vida na, sobre e através das paisagens. Promovem reflexão também sobre a forma a qual essa paisagem é revelada e passa a ser imaginada por meio da performance, por um engajamento corporificado com ela que é capaz de problematizar a multiplicidade de aspectos visuais, aurais, táteis, e nesse caso, estomacais viscerais, da vida na paisagem.

Com o presente artigo, acredito que se delineiam caminhos para se performar uma paisagem, fundamentado não só na experiência de contato com ela, mas também de reflexão crítica a partir de Annete Arlander, e de outros, além das minhas próprias práticas enquanto performerpesquisador. Daí surgiram todos os elementos que compõem a performance, seus objetos postos em performance coletiva (vassoura, vestível, máscara, baião) e suas estratégias de convocatória para a participação, decididas no fluxo de retroalimentação entre pesquisa teórica e 
experiência vivida. Esses objetos em performance chamam atenção tátil ao que membros de comunidade verbalizam em vídeo sobre suas vidas e experiências de contato com o carvão.

Não se fecha, nesse sentido, uma abordagem definitiva para a performance da paisagem contaminada, mas se ensejam formas múltiplas de modular essa paisagem e a vida nessa paisagem em um ambiente expositivo que transita entre a performance a videoinstalação. É um modelo fruto de uma situação específica, mas que desdobrará o pensamento crítico de abordagens futuras de poéticas que se afetem por tais questões.

\section{NOTAS}

1. A série foi apresentada como vídeoarte na Mostra Nacional de Intervenções e Performances 2017, no Now\&After Videoart Festival de 2016, ocorrido no StateDarwin Museum em Moscou, na Rússia; e no CICA Museum Experimental Video Fall 2016 Exhibition, em Gimpo-si, Coréia do Sul; na forma de performance audiovisual no $69^{\circ}$ Salão de Abril, em Fortaleza, no Convergência Mostra de Performance Arte do Sesc-Tocantins, na mostra Entre-Performances da Temporada de Arte Cearense do Centro Dragão do Mar e em eventos do PPG-ARTES/UFC.

2. Os Wayúu são uma população indígena que habita o norte colombiano, principalmente La Guajira e o oeste da Venezuela. Trata-se de uma das mais numerosas populações indígenas da Colômbia. Durante os dias em que estive por lá, escutei durante a maior parte do tempo eles falarem o wayuunaiki, a língua Wayúu, idioma bastante vital na região. De acordo com Rodriguez (2012) os Wayuú se encontram organizados em cerca de 23 clãs, dos quais se pertence a partir da linha materna.

3. Termo da estratigrafia, controverso, mas que prevalece para definir a era geológica em que nos encontramos atualmente, marcada pelos efeitos de uma série de fatores advindos de ações de humanos e seus sistemas de produção industrial e exploração da terra como recurso.

\section{REFERÊNCIAS}

ARLANDER, Annette. Performing Landscape - Notes on Site-specific Work and Artistic Research (Texts 2001-2011). Acta Scenic 28. Theatre Academy Helsinki. 2012 disponível em [https://helda.helsinki.fi/bitstream/ handle/10138/37613/Acta_Scenica_28.pdf]. acessado 10 de janeiro de 2015 .

BECERRA, C. A. Construcción del Puerto Brisa en territorio ancestral, destrucción del cerro sagrado Jukulwa y desconocimiento de los derechos fundamentales de los pueblos indígenas koguis, arhuacos, kankuamos y wiwas de la Sierra Nevada de Santa Marta. El Otro Derecho, n. 40, jun. 2009.

BENNETT, O.; MCDOWELL, C. Displaced: The Human Cost of Development and Resettlement. New York: Palgrave Macmillan, 2012.

BJUREBY, E.; BRITTEN, M.; CHENG, I.; KAZMIERSKA, M; MEZAK, E.; MUNNIK, V.; NANDI, J.; PENNINGTON, S.; ROCHON, E.; SCHULZ, N.; SHAHAB, N.; VINCENT, J.; WE, M. The true cost of coal: how people and the planet are paying the price for the world's dirtiest fuel. Disponível em: <http://www.greenpeace.org/australia/en/ what-we-do/climate/resources/reports/thetrue-cost-of-coal>. Acesso em: 03 jul. 2011.

ELSAESSER, Thomas. Film Theory - an introduction through the senses. Nova York: Routledge, 2015 (2edição).

HANNULA, Mika. JUHA, Suoranta. TERE, Vadén. Artistic Research - Theories, Methods and Practices. Helsinki: Academi of Fine Art and Gothenburg. University of Gothenburg. 2005.

HASEMAN, Brad C. A Manifesto for Performative

Research. Media International Australia Incorporating Culture and Policy: quarterly journal of media research and resources theme issue 'Practice-led-Research'. No 118. 98-106. http://eprints.qut.edu.au/3999/(11.10.2012)

HJORTH, Larissa. PINK, Sarah. SHARP, Kristen. WILLIAMS, Linda. Screen Ecologies: Art, Media, and the Environment in the Asia-Pacific Region, Cambridge, MA: MIT Press, 224 pp., 2016.

KOZEL, Susan. Closer:Performance, Technologies, Phenomenology. Cambridge, Mass., and London: The MIT Press, 2007.borgdoff 
PALOMINO, S. 'El rio que se robaron', lo que está matando a una comunidad indígena en Colombia. El País, 2016. Disponível em: <http:// cultura.elpais.com/cultura/2016/09/01/ actualidad/1472755464_636380.html>. Acesso em: 21 out. 2016.

\section{SOBRE O AUTOR}

Ruy Cezar Campos Figueiredo é artista visual e pesquisador. Doutorando em Comunicação, linha Tecnologias da Comunicação e Cultura na Universidade do Estado do Rio de Janeiro - UERJ (financiado por bolsa CAPES). Mestre em Artes, linha Artes e Processo de Criação: Poéticas Contemporâneas na Universidade Federal do Ceará - UFC (2018 / financiado por bolsa da FUNCAP), Bacharel em Audiovisual e Novas Mídias na Universidade de Fortaleza UNIFOR (2015). Em suas obras e escritos tem destacado fluxos discretos de circulação de dados e materialidades, performado paisagens infraestruturais e ambientalmente contaminadas, abordado materialidades midiáticas no contexto do clima contemporâneo, exercitado metodologias da arte e da arqueologia das mídias, assim como investigado modos de corporificação em vídeos compartilhados, dentre outros temas. Participou de bienais, exposições, residências e festivais de videoarte internacionais, nacionais e no Ceará. 


\title{
EXPERIMENTAÇÕES ARTÍSTICAS NA ANIMAÇÃO OCIDENTAL:
} BEGONE DULL CARE

\author{
ARTISTIC EXPERIMENTS IN WESTERN ANIMATION:
}

BEGONE DULL CARE

Regilene Aparecida Sarzi-Ribeiro
UNESP/Bauru/SP

João Víctor Kurohiji Bonani

UNESP

\section{Resumo}

O presente artigo tem como tema a animação experimental e suas características, campo repleto de inovações técnicas e artísticas que é mantido à margem dos estudos sobre o cinema animado. Portanto, tem como objetivos definir certas características de uma animação experimental e identificar e descrever traços e características do que se considera uma animação experimental no curta animado "Begone Dull Care" (1949) de Norman McLaren (1914-1987) e Evelyn Lambart (19141999) através de uma pesquisa teórica, bibliográfica e descritiva do tipo qualitativa, de natureza básica/ pura a partir da coleta de dados e análise documental que compreende a identificação, verificação e apreciação de documentos (bibliográficos e obras audiovisuais) com determinados fins, como análise de conteúdo por meio da descrição do filme de animação "Begone Dull Care" (1949). Diferente da animação comercial que tem como objetivo comercial agradar o público sem a preocupação da satisfação artística ou pessoal dos animadores dos estúdios, e buscar soluções formais que facilitem a produção em larga escala dos filmes animados, a animação experimental vai se distinguir por experimentações técnicas e estéticas que desafiam os limites da linguagem e ampliam seu potencial expressivo. Com caráter de vanguarda, voltada à criação artística e à experimentação, a animação experimental terá desenvolvimento na Europa do início do séc. XX. Artistas como McLaren e Oskar Fischinger exploraram técnicas que ampliam o potencial plástico das animações. O termo incorporou diversas nomenclaturas ao longo dos anos como animação independente ou de autor.
"Begone Dull Care" é produto desse espírito que desafia o tradicional através de experimentações. Nele, McLaren utiliza o método de animação direto sobre a película e sincroniza cores e formas gráficas animadas pelo som de jazz. McLaren e Lambart adotam formas simplificadas e abstratas para maior liberdade de criação e, durante tal processo empírico, incorporam imprevistos, acidentes e materiais não convencionais como potencializadores da expressividade através de suas experimentações com a materialidade do filme.

\section{Palavras-chave:}

Arte do Século XX; Animação Experimental; Begone Dull Care; Norman McLaren e Evelyn Lambart.

\section{Abstract}

The present article has as its theme the experimental animation and its characteristics, a field full of technical and artistic innovations that is kept aside from the studies on animated cinema. Therefore, it aims to define certain characteristics of an experimental animation and to identify and describe traits and characteristics of what is considered an experimental animation in the animated short film Begone Dull Care in Norman McLaren's (1914-1987) and Evelyn Lambart (1914). Bibliographical and audio-visual works with a specific purpose, such as the identification, verification and evaluation of documents (bibliographical and audiovisual works), of a basic / pure nature, based on data collection and 
documentary analysis, as content analysis through the description of the animated film "Begone Dull Care" (1949). Unlike commercial animation that aims to please the public without the concern of the artistic or personal satisfaction of studio animators, and seek formal solutions that facilitate the large-scale production of animated films, the experimental animation will be distinguished by technical experimentation and aesthetics that challenge the limits of language and amplify its expressive potential. With avant-garde character, focused on artistic creation and experimentation, the experimental animation will be developed in Europe at the beginning of the century. XX. Artists like McLaren and Oskar Fischinger explored techniques that amplify the plastic potential of animations. The term has incorporated several nomenclatures over the years as independent or author animation. "Begone Dull Care" is a product of this spirit that challenges the traditional through experimentation. In it, McLaren uses the direct animation method on the film and synchronizes colors and graphic shapes animated by the sound of jazz. McLaren and Lambart adopt simplified and abstract forms for greater freedom of creation and, during such an empirical process, incorporate contingencies, accidents and unconventional materials as enhancers of expressiveness through their experimentation with the materiality of the film.

Keywords:

20th Century Art, Experimental Animation, Begone Dull Care, Norman McLaren and Evelyn Lambart.

\section{A ANIMAÇÃO EXPERIMENTAL}

A pesquisa por novas técnicas a fim de ampliar o potencial expressivo da animação feita por animadores independentes como Len Lye e Norman McLaren trouxe para o gênero uma grande multiplicidade de experimentações. A produção surgida a partir do desenvolvimento artístico no início do século XX colocou a linguagem do cinema de animação em uma constante renovação.

Com caráter de arte de vanguarda, voltada à criação artística e inteiramente à experimentação, a animação experimental é um trabalho de elaboração estética e visual feito por animadores ou artistas que rejeitam as formas artísticas e estruturais tradicionais. As práticas realizadas trazem para o cinema todos os meios das experiências plásticas habituais às artes visuais.

Segundo Barbosa Júnior (2005), os animadores/ artistas em uma recusa de utilizar o conhecido, exploram formas visuais pouco ou não recorrentes na animação comercial e optam pela inovação ao desenvolver técnicas que serão utilizadas pelos próprios ou em um grupo reduzido de animadores. Esse aspecto da expressão individual em uma produção artesanal da animação reforça o aspecto de arte de vanguarda da animação experimental. Para Denis:

Trabalhando a materialidade do fotograma, a cinzelagem, o intervalo, a própria ideia da montagem ou da variação, estes cineastas utilizam muitas vezes estas técnicas para criar um espaçotempo diferente do cinema "clássico". Não se trata simplesmente de filmar imagem a imagem, ou seja, de imprimir a película (ou, hoje em dia, de digitalizar os desenhos) para criar fases clássicas, mas de modificar a própria matéria da imagem (DENIS, 2010, p.71).

Diferente da animação tradicional, as obras de animação experimental, em sua maioria, serão apreciadas por outros artistas, funcionando como um campo de experimentações e desenvolvimento de ideias que podem vir a ser incorporadas pela animação de criação comercial e pelo cinema em geral. Como exemplo, o trabalho pioneiro de Len Lye (Colour Box, 1938) e as posteriores pesquisas de animação diretamente realizadas sobre a película de Norman McLaren que o levaram, mais tarde, ao aperfeiçoamento do desenho animado da United Productions of America (UPA), fundada em 1941.

Neste contexto, estando os Estados Unidos dominados pela animação comercial, restaria à Europa a chance de explorar as possibilidades da animação deixadas em aberto pelos norteamericanos. Parte dos artistas locais havia emigrado para os Estados Unidos devido a Primeira Guerra Mundial e, como consequência, restaram para a animação independente na Europa os poucos recursos e patrocínios governamentais. Com financiamento próprio ou com, ocasionalmente, algum financiamento particular, surgiram artistas que contribuíram para com inovações artísticas e técnicas do cinema de animação. 


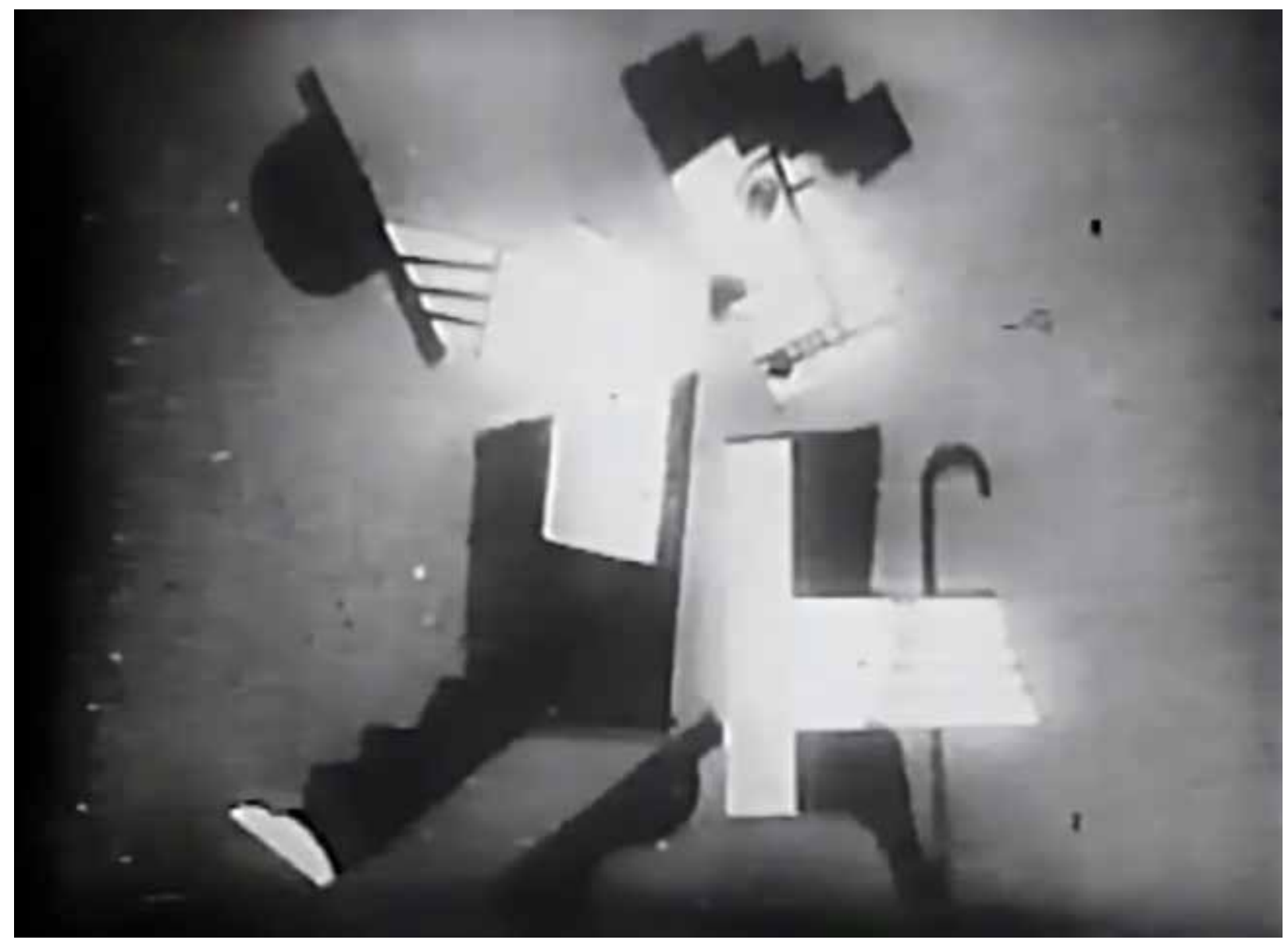

Figura 1 - Frame da animação Ballet Mécanique (1924), Fernand Léger e Dudley Murphy. Fonte: https://youtu.be/tOvnQ9Vqptw

É o caso de pintores das vanguardas artísticas que realizaram pesquisas no campo da animação como artistas membros do movimento surrealista que utilizaram a animação em seus filmes. 0 mais conhecido deles é o curta Ballet Mécanique (1924) do cubista Fernand Léger, realizado em parceria com o diretor Dudley Murphy cujas formas animadas são inspiradas por ritmos musicais do dadaísta Hans Richter.

Neste contexto foram os artistas, que imergiram no campo das possibilidades técnicas e estéticas do cinema de animação, que trouxeram avanços artísticos a linguagem. Ainda conforme Denis:

Para além de ser uma técnica que permite à pintura animar-se para ganhar vida e extravasar o espaço da galeria, ou até ultrapassar a própria pintura, a animação foi também utilizada nas vanguardas com o objetivo de perverter o real. Através da técnica imagem a imagem, a filmagem real é "transformada", para permitir ao espectador aceder a um estado de sonho ou criticar a sociedade e o mundo da arte (DENIS, 2010, p. 63).
Antes dos anos 1920, o artista alemão Walther Ruttman realizou animações abstratas que exploraram a expressividade do movimento de formas geométricas.

Sua famosa série de animações Opus (1921-1925), figura 2, combinava uma sucessão de formas onduladas e geométricas com música. Para a realização de seus filmes animados, Ruttmann desenvolveu uma técnica na qual suas formas eram montadas em hastes e iluminadas, deixando visível apenas suas partes superiores. 0 artista alemão também desenvolveu pesquisas na pintura em vidro e na animação de areia e de sabão.

Também na Alemanha, nos anos de 1930, surge o animador experimental Oskar Fischinger, que dará continuidade ao trabalho de Ruttman.

Fischinger, figura 3, utiliza-se da técnica de animação direto sobre a película, onde se obtém uma combinação de ritmo e cor. Norman McLaren, que estudaremos em detalhes mais adiante, se 


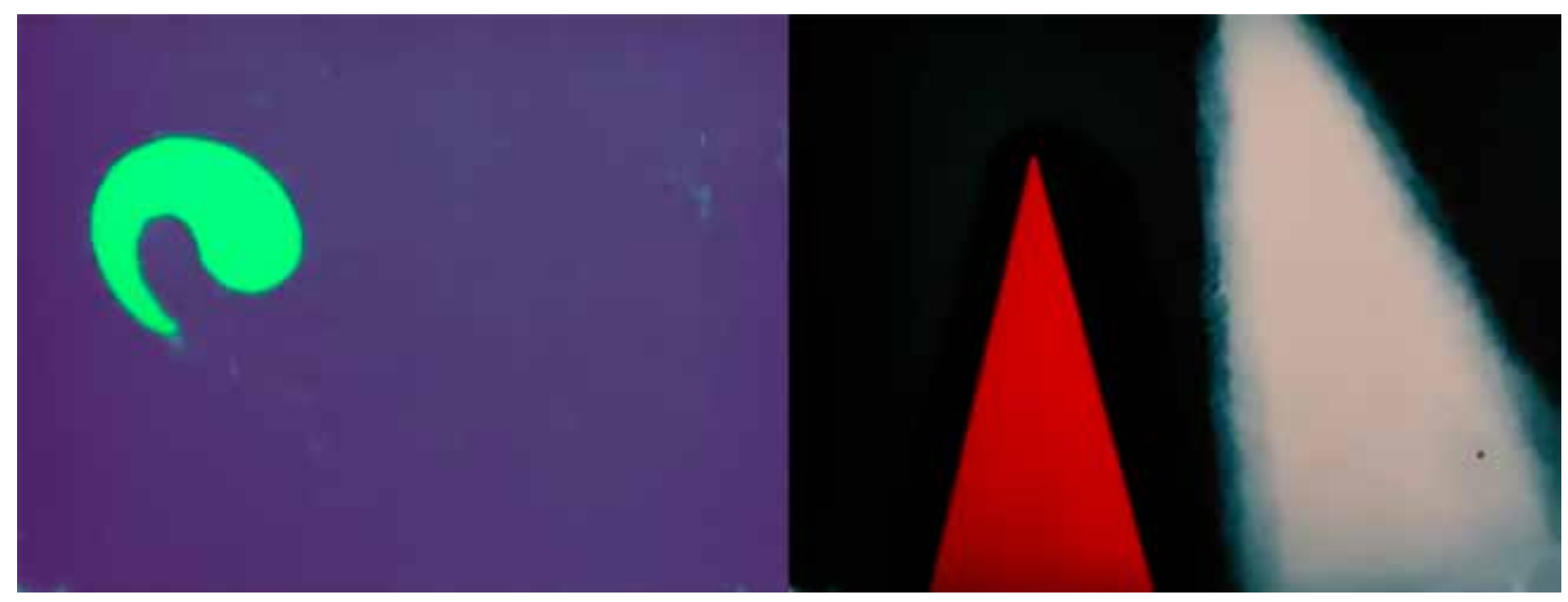

Figura 2 - Frames da animação Lichtspiel: Opus / (1921), Walther Ruttmann. Fonte: https://vimeo.com/42624760

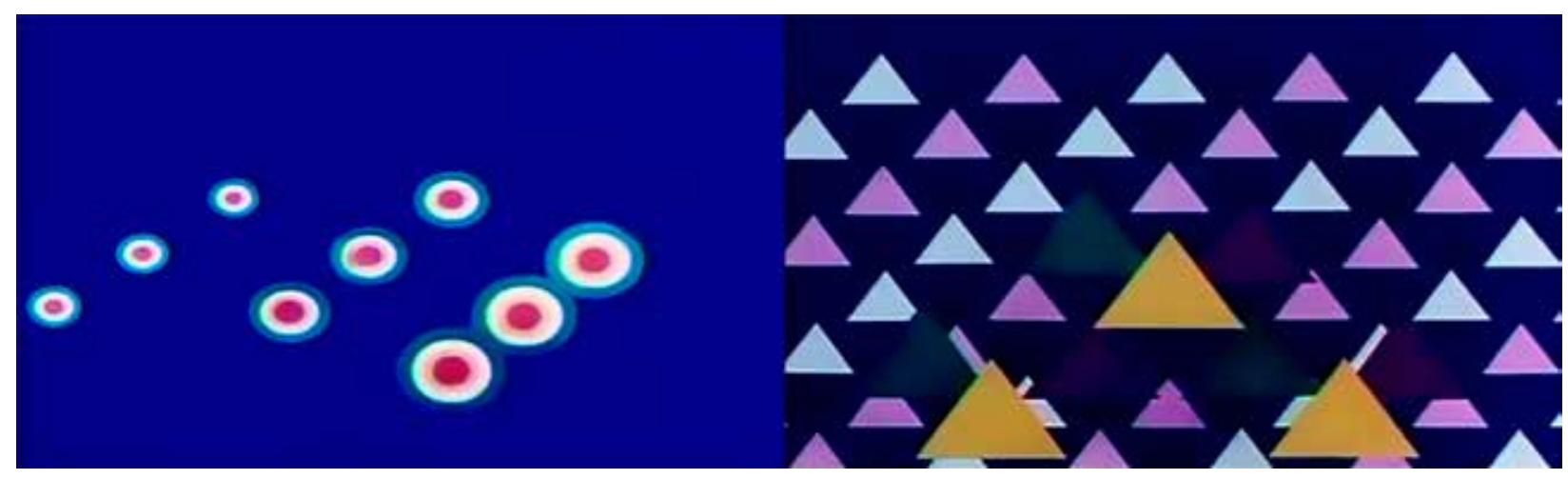

Figura 3 - Frames da animação An Optical Poem (1938), Oskar Fischinger. Fonte: https://youtu.be/6Xc4gOOFFLk

tornará o nome mais conhecido ligado a esse método. As pesquisas de Fischinger expandiram a animação experimental por meio de diversas inovações técnicas, como suas animações com formas de cera recortada:

Numa equivalência ao automatismo surrealista, ele confeccionou uma engenhoca que efetuava cortes automáticos de fatias extremamente finas de blocos de cera especialmente preparados, revelando formas inusitadas de espirais e estrias multicoloridas. Depois de fotografadas frame a frame, essas imagens apresentavam formidáveis padrões aleatórios de abstrações em movimento ao serem projetadas, Essas configurações abstratas móveis adaptadas à música atingiram requintes de expressão (BARBOSA JÚNIOR, 2005).

O suíço Rudolf Pfenninger, assim como Fischinger, realizou pesquisas no campo do som desenhado, forma de animação abstrata que une os sons de instrumentos musicais às formas animadas, figura 4.
Pfenninger começou a experimentar no campo do filme em 1918 e, a partir de 1921, trabalhou com desenhos animados. Mais tarde, Pfenninger chegou a desenvolver uma máquina que escreve sons, concebendo-os como formas gráficas, uma "conversão eletroacústica de figuras geométricas desenhadas"1. A inovação de seus sons obtidos a partir da sucessão de formas geométricas representa, segundo Miranda (1971), uma técnica de síntese da música.

Na mesma época nos Estados Unidos, em Nova Iorque e na Califórnia, animadores começavam a explorar e ampliar técnicas pouco utilizadas. Douglas Crockwell foi um importante nome na animação experimental da época que explorava técnicas para expandir o potencial plástico das animações. Crockwell produziu seus primeiros filmes no fim da década de 1930. 


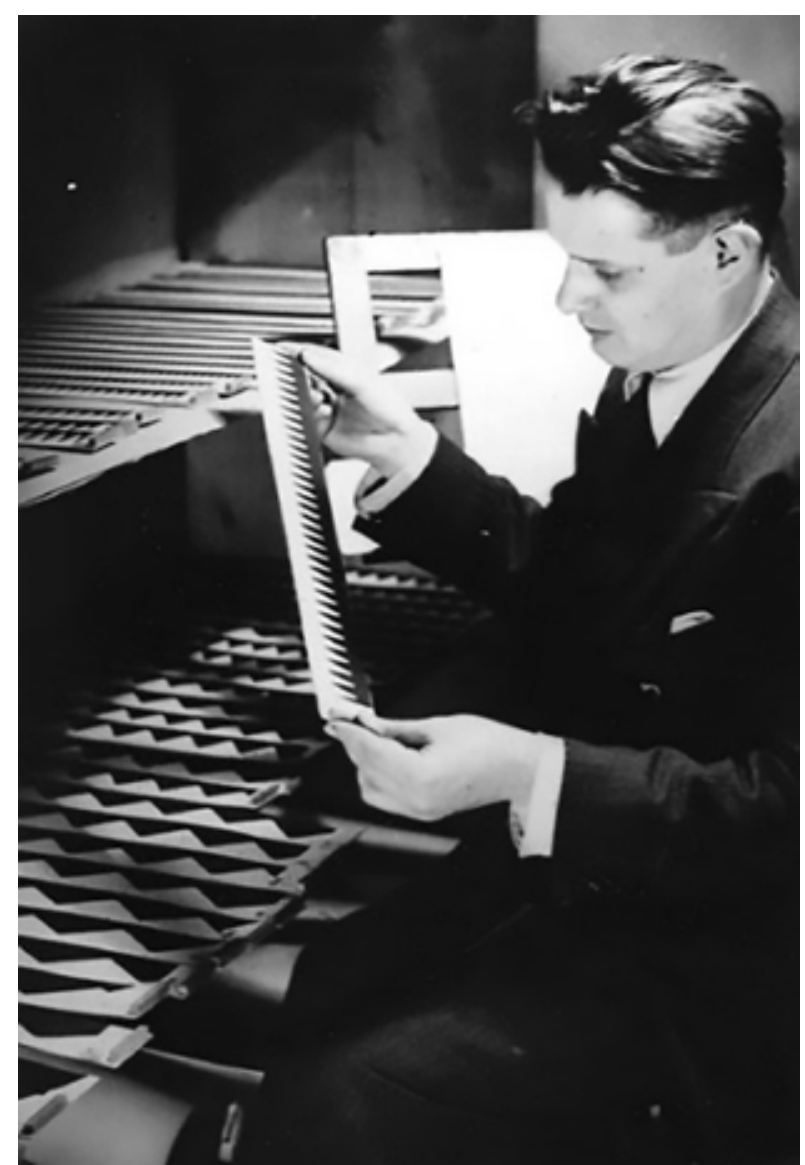

Figura 4 - Rudolf Pfenninger com tiras de som desenhadas à mão, 1932. Fonte: Pfenninger Archive, Munique.

Em 1944, o artista patenteou um sistema de realização de animações abstratas com músicas e chegou a oferecer esse sistema a redes de televisão e aos estúdios Disney. Seu filme Glens Falls Sequence (1946), figura 5, é um compilado de técnicas e estilos gráficos. Em uma das sequências, o artista usa seus dedos para pintar sobre placas de vidro. Crockwell também chegou a fazer uso semelhante do método das formas cortadas de cera de Fischinger.

A artista Mary Ellen Bute explora o potencial de diversos recursos, como a animação de recortes e a animação de objetos, e utiliza a técnica de animação tridimensional conhecida como pixillation, termo cunhado por Norman McLaren na década de 1950 para designar a técnica de stop-motion utilizada por Georges Méliès.

Bute realizou sua primeira animação experimental na década de 1930, Rythm in Light, toda em preto e branco. Synchromy No.4 - Escape (1937-38), figura 6, é uma de suas principais produções em cores, Bute começou a utilizar cores em seus trabalhos por volta da década de 1940.

O britânico Len Lye foi um pioneiro na animação abstrata. Seu filme de animação Colour Box (1938), figura 7, é considerado a primeira animação pintada diretamente sobre a película e mostrada ao público.

Lye também utilizou a mesma técnica em outros filmes como Kaleidoscope (1935) e Musical Poster (1940). No fim dos anos de 1940, o escocês Norman McLaren expandia de forma significativa as possibilidades expressivas das experiências abstracionistas de animação realizadas diretamente sobre a película de Len Lye.

Assim como suas possibilidades, o termo animação experimental estendeu-se e incorporou ao longo dos anos diferentes nomenclaturas que variam de acordo com teóricos ou técnicas empregadas. Características da animação experimental fazem surgir outros termos como a animação independente (BARBOSA JÚNIOR, 2005), um contraponto às animações tradicionais feitas em estúdios e a animação abstrata advinda das pesquisas do som desenhado, por exemplo, que produzem resultados totalmente abstratos.

Pela afinidade com as artes visuais, Denis (2010) menciona o termo animação artística e Graça (2006) utiliza-se da animação de autor como ênfase no caráter de expressão própria e no papel pioneiro do artista experimentador:

O discurso, no filme animado de autor, faz-se no âmbito das condições elementares subjacentes à produção de um filme: o dispositivo (em evolução) que a suporta, os modos de codificação que se vão disponibilizando e aparecendo como próprios num tempo e num lugar determinados. Condições nas quais o autor aparece, fundamentalmente, como explorador e inventor. A postura deste último é a daquele que examina e integra as margens da substância expressiva singular que se apresenta a partir do próprio filme enquanto processo. Embora realizado numa perspectiva de comunicação porque feito na expectativa do espectador -, o filme emerge como uma possibilidade ou conjunto de possibilidades significativas: voltado para a exploração e invenção dos próprios meios de significação. Explicitamente, o filme animado de autor apresenta questões sobre a própria substância expressiva fílmica, no contexto da qual se propõe, por essa razão, como ocorrência crítica (GRAÇA, 2006, p.17). 


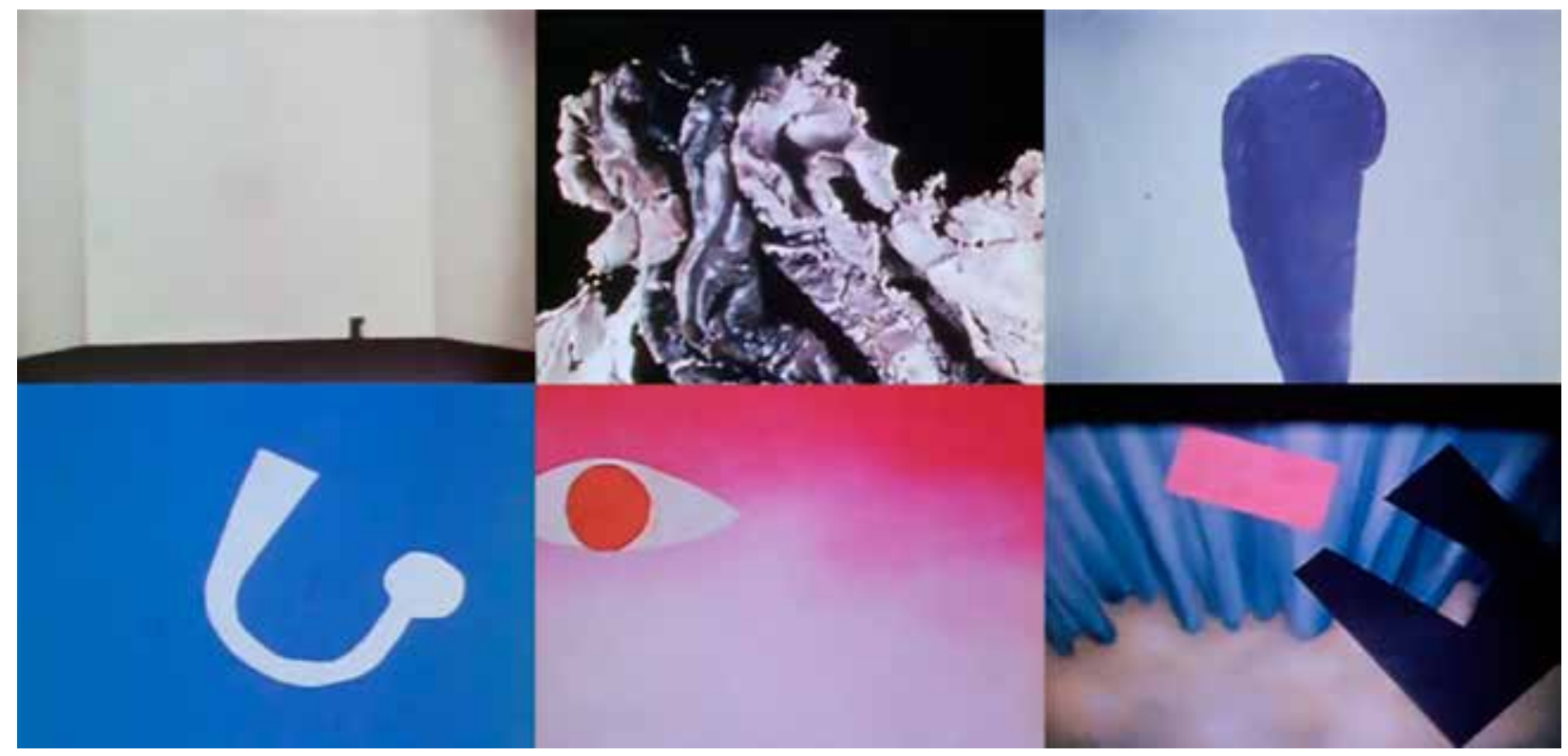

Figura 5 - Frames da animação Glens Falls Sequence (1946), Douglas Crockwell. Fonte: https://youtu.be/Et1rGosGbwg

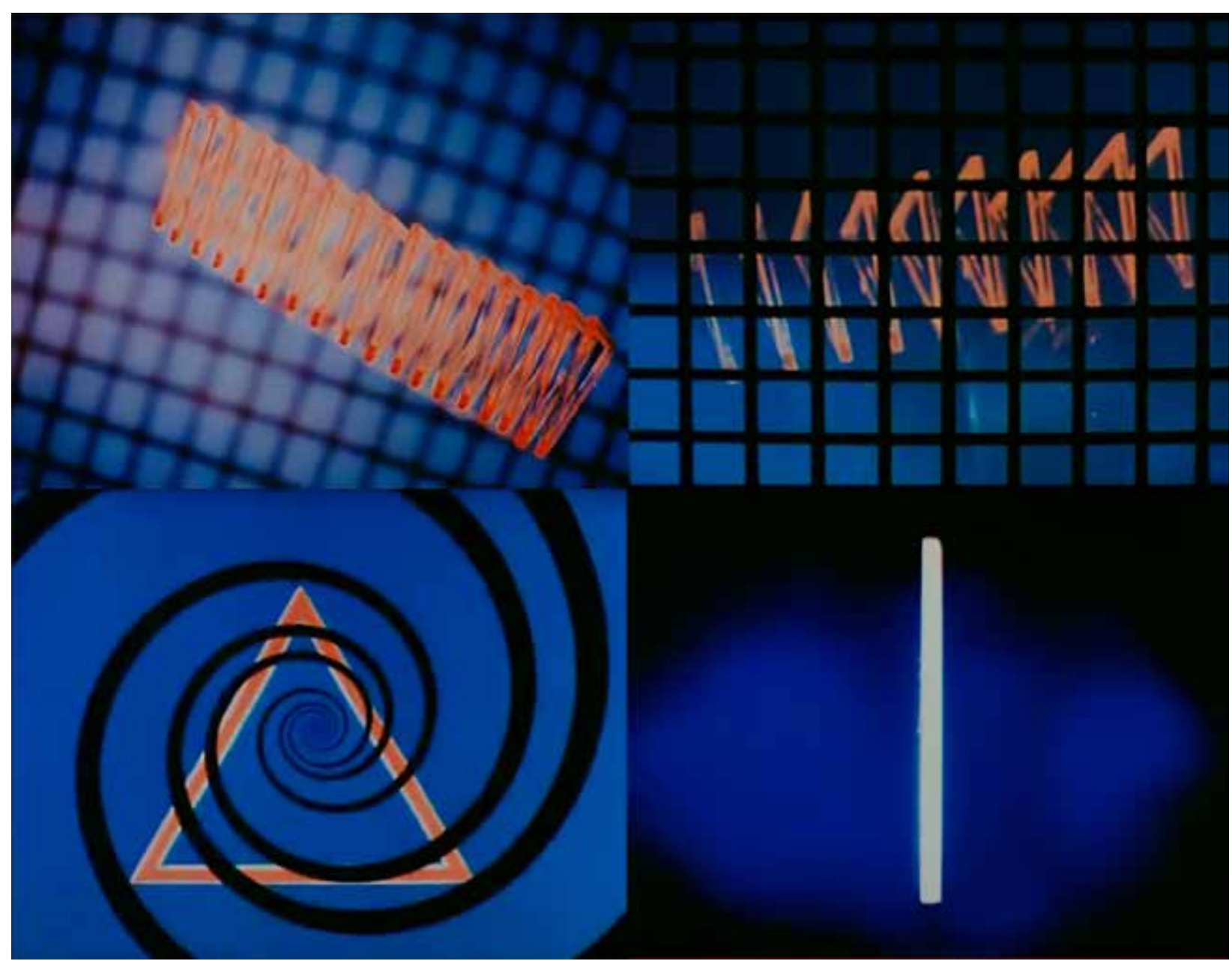

Figura 6 - Frames da animação Synchromy No.4 - Escape (1937-38), Mary Ellen Bute e Ted Nemeth. Fonte: https://youtu.be/YRmu-GcClls 


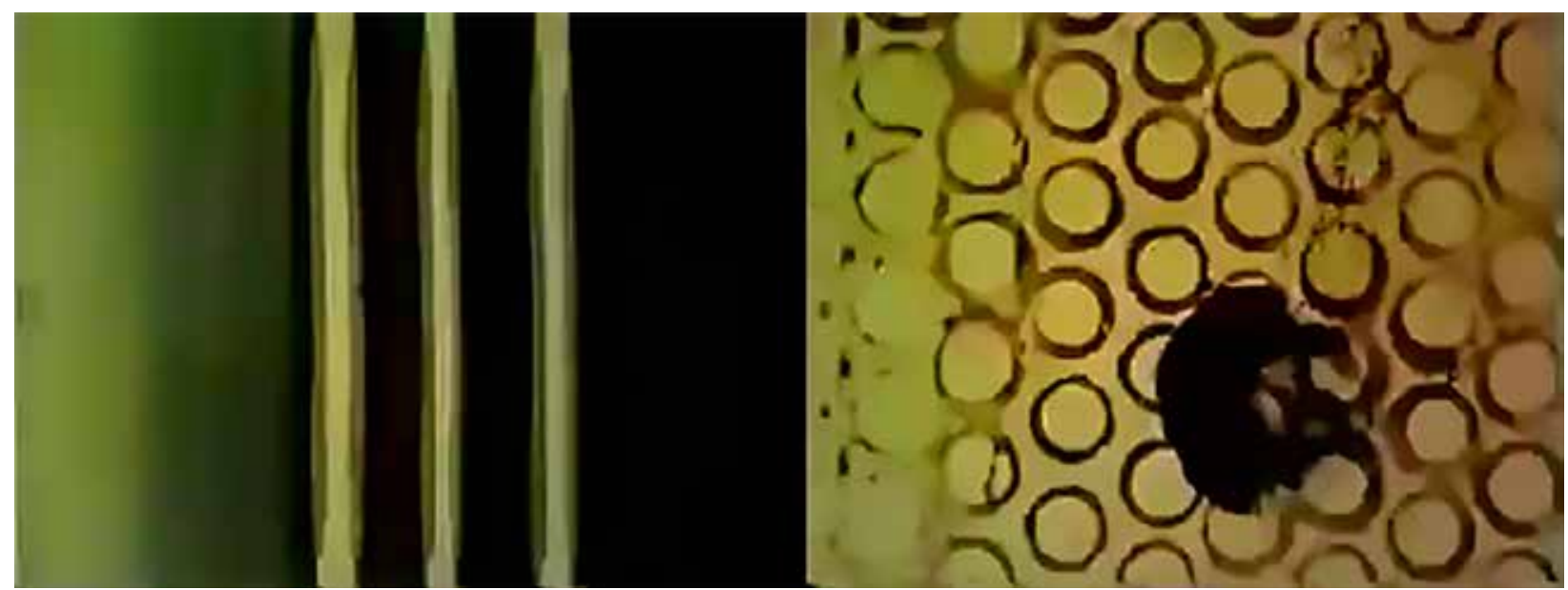

Figura 7 - Frames da animação Colour Box (1938), Len Lye. Fonte: https://vimeo.com/28834678

Sendo assim, o vasto campo do cinema de animação experimental é resultado de incontáveis experiências que inovaram e enriqueceram a linguagem da animação. São as pesquisas feitas por animadores dedicados ou artistas que, voltados à criação artística, se afastam do tradicional e da animação comercial.

\section{NORMAN MCLAREN E BEGONE DULL CARE}

Pintor e animador britânico, Norman McLaren (1914-1987) estudouna Escola de Arte de Glasgow, na Escócia, e iniciou suas experimentações no cinema de animação na década de 1930. Nessa época desenvolve a técnica de pixillation, utilizando-a para a realização de filmes com atores reais. Em 1939, muda-se para Nova lorque em decorrência do início da Segunda Guerra Mundial e realiza a animação Spook Sport (1939) com Mary Ellen Bute.

Nos anos de 1940, encontrará na National Film Board of Canada as condições para iniciar com êxito suas investigações técnicas e artísticas. Será na NFB que McLaren conhecerá Evelyn Lambart (1914-1999), sua colaboradora em diversos trabalhos, como na animação Begone Dull Care (1949) que será estudada adiante.

Com aproximadamente cinquenta curtasmetragens no currículo e inúmeras pesquisas expressivas no campo do movimento animado, McLaren experimenta todas as técnicas familiares à animação. Os trabalhos de McLaren contribuíram com inovações e tinham uma constante relação com a música. O mesmo difundiu e explorou o método de animação direto sobre a película de Len Lye:

[...] que consistia em desenhar diretamente com caneta e tinta sobre o filme de película virgem $35 \mathrm{~mm}$ sem o uso de uma câmera. Cada pequeno desenho era feito em um frame da película, diferenciandose um pouco do desenho feito no frame anterior. Isso causaria a ilusão de movimento assim que o filme fosse enrolado e projetado em uma superfície plana. Para desenvolver seus trabalhos, McLaren fazia uso de equipamentos que o auxiliavam na produção das animações. Ele utilizava uma mesa de desenho inclinada e que possuía um compartimento responsável por deixar a película em filme aberta na vertical, assim ele poderia pintar cada frame com mais facilidade. Outro aparato técnico bem útil era uma grande lupa, dotada de uma haste móvel, que Ihe permitia uma melhor visualização dos pequenos frames enquanto pintava-os individualmente (TEIXEIRA, 2015, p. 26).

McLaren "[...] encarna, à perfeição, o protótipo do artista/cientista numa busca intensa e apaixonada para saciar sua curiosidade técnica a serviço da expansão dos limites artísticos da ação animada" (BARBOSA JÚNIOR, 2005, p.92).

O curta animado Begone Dull Care (1949), figura 8, feito em parceria com Evelyn Lambart é um dos vários resultados das experimentações de Norman McLaren com o método de animação direto sobre a película, iniciado por Lye e Fischinger.

A referida animação une cores e formas gráficas em sua maioria abstratas, pintadas por Lambart e McLaren ao som do jazz canadense do Oscar Peterson Trio, foi produzida pela 


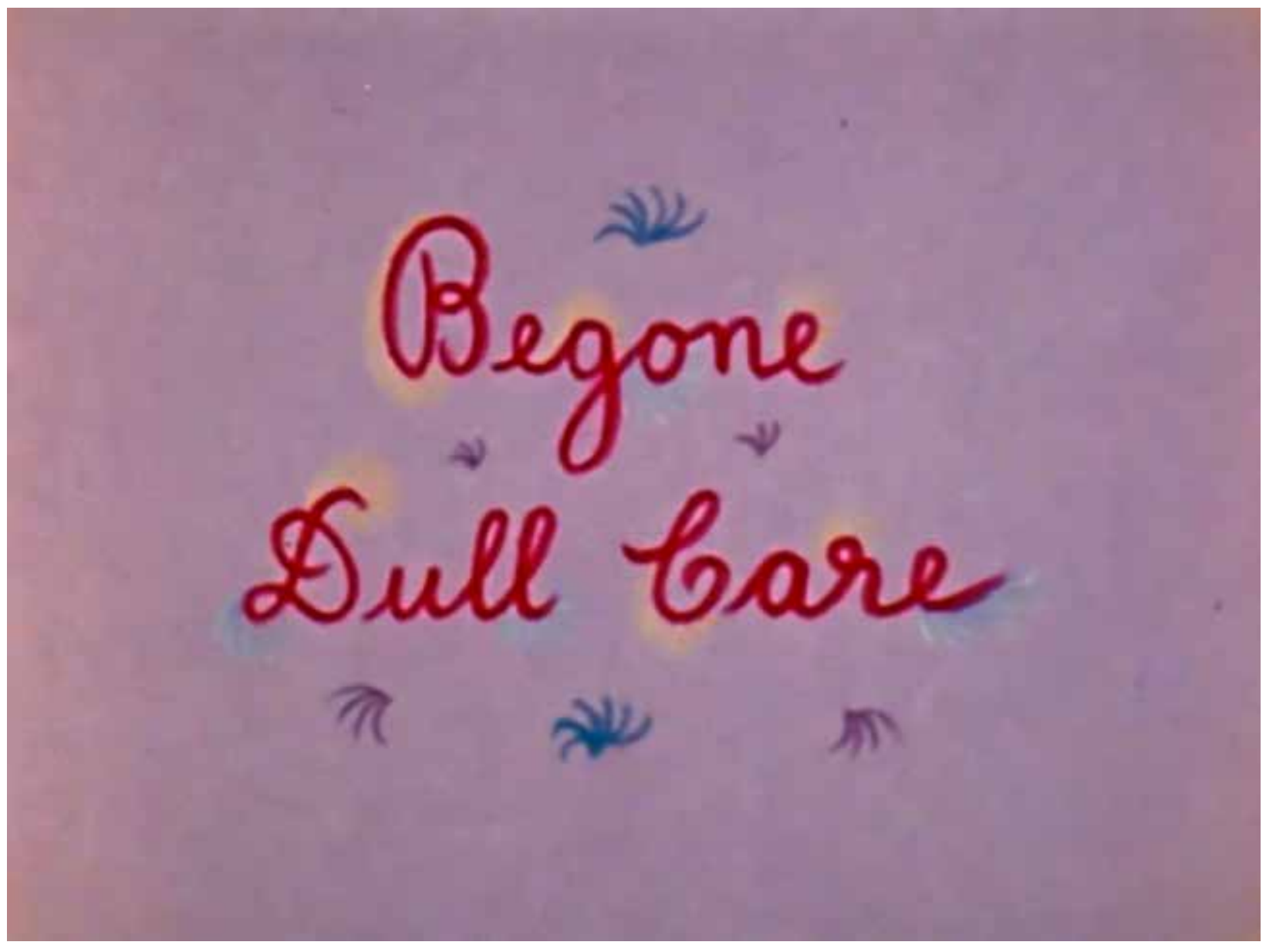

Figura 8 - Frame da animação Begone Dull Care (1949), 00.19min, Norman McLaren e Evelyn Lambart. Fonte: https://youtu.be/Or2COvWPO4Y

National Film Board of Canadá e ganhou seis prêmios internacionais entre 1949 e 1954.

Begone Dull Care apresenta uma paleta de cores com predomínio de tons pretos, brancos, cores frias, como azul e roxo, e cores quentes, como vermelho e rosa. 0 movimento das formas e das cores é guiado pelas transições e sucessões das películas pintadas por McLaren e Lambart. Tal sucessão das películas, e consequentemente 0 movimento das formas, acompanham e dançam no ritmo do jazz, o que causa uma sincronização entre som e imagem.

As pinturas feitas pela dupla, assim como nas animações experimentais de Fischinger e Lye que trabalham o som desenhado, são em sua maioria abstratas - compostas por manchas, linhas, padrões, formas simplificadas e orgânicas. A abstração, simplificação e informalidade podem ser entendidas como uma solução para o registro óptico da música do Oscar Peterson
Trio e produto da liberdade nas experimentações técnicas e materiais.

O abstracionismo nessas animações as afasta da animação comercial que explora o figurativo como recurso de empatia para com o público, uma vez que o compromisso de agradar o público em geral se perde com as imagens sem relação direta com a realidade, como na figura 9. Algumas formas figurativas simplificadas, figura 10, também foram pintadas, mas são apresentadas em frames que duram milésimos de segundos e por isso nos passam quase despercebidas.

O processo de criação de Begone Dull Care, assim como o método de elaboração empregado por McLaren é uma chave para entendermos sua categorização como uma animação experimental:

McLaren tinha consciência da força com que a máquina imprime sua presença naquilo que realiza. Como forma de recuperar dela a autoria de seu filme, era com empenho que mantinha um espaço de

Visuais

79 


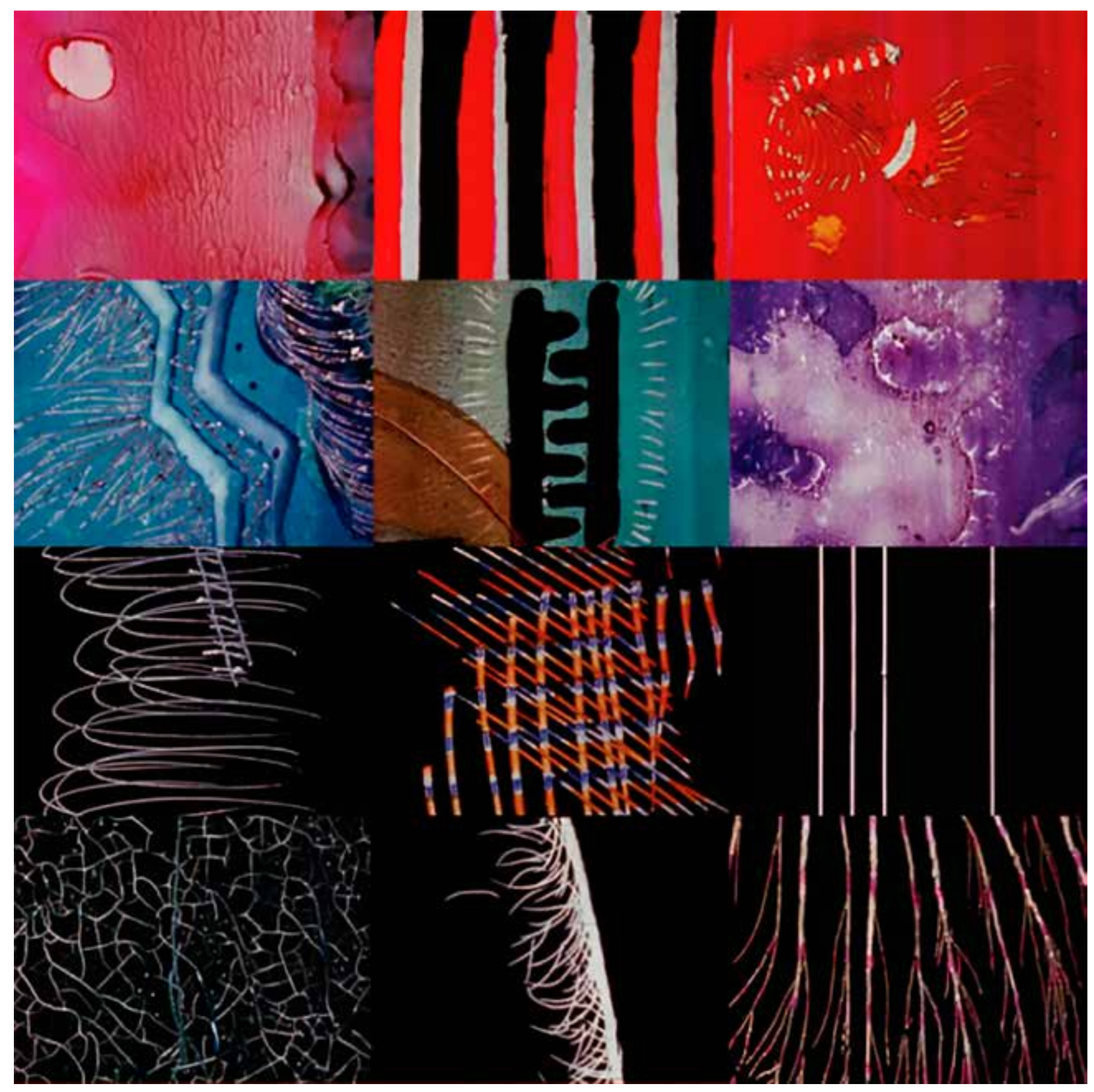

Figura 9 - Frames da animação Begone Dull Care (1949). Norman McLaren e Evelyn Lambart. Fonte: https://youtu.be/Or2COvWPO4Y

possibilidades aberto a soluções poéticas libertadas pelo erro e pelo imprevisto. Ainda que planificada com rigor, a intenção original do projeto era, muitas vezes, esquecida em função de resultados mais interessantes, prometidos por qualquer material ou ação fortuita (GRAÇA, 2006, p.112).

McLaren incorporou o imprevisto, que antes seria uma problemática, à materialidade da película, tornando obstáculos e acidentes em potencializadores da expressividade através de suas experimentações. O animador utilizou-se do problema de poeira excessiva presente no momento de realização da animação e o erro do projetor ao arranhar a superfície da película como soluções poéticas para suas composições.

McLaren e Lambart, ao experimentarem com a materialidade das pinturas nos fotogramas, produzem composições totalmente abstratas e deslocam para o cinema pesquisas plásticas familiares às artes visuais. Podemos perceber visualmente a reação entre a poeira oleosa e a tinta acrílica na superfície dos fotogramas nos frames presentes na figura 11. A dupla de animadores também experimentou utilizar diversos materiais para aplicar e tratar a tinta 


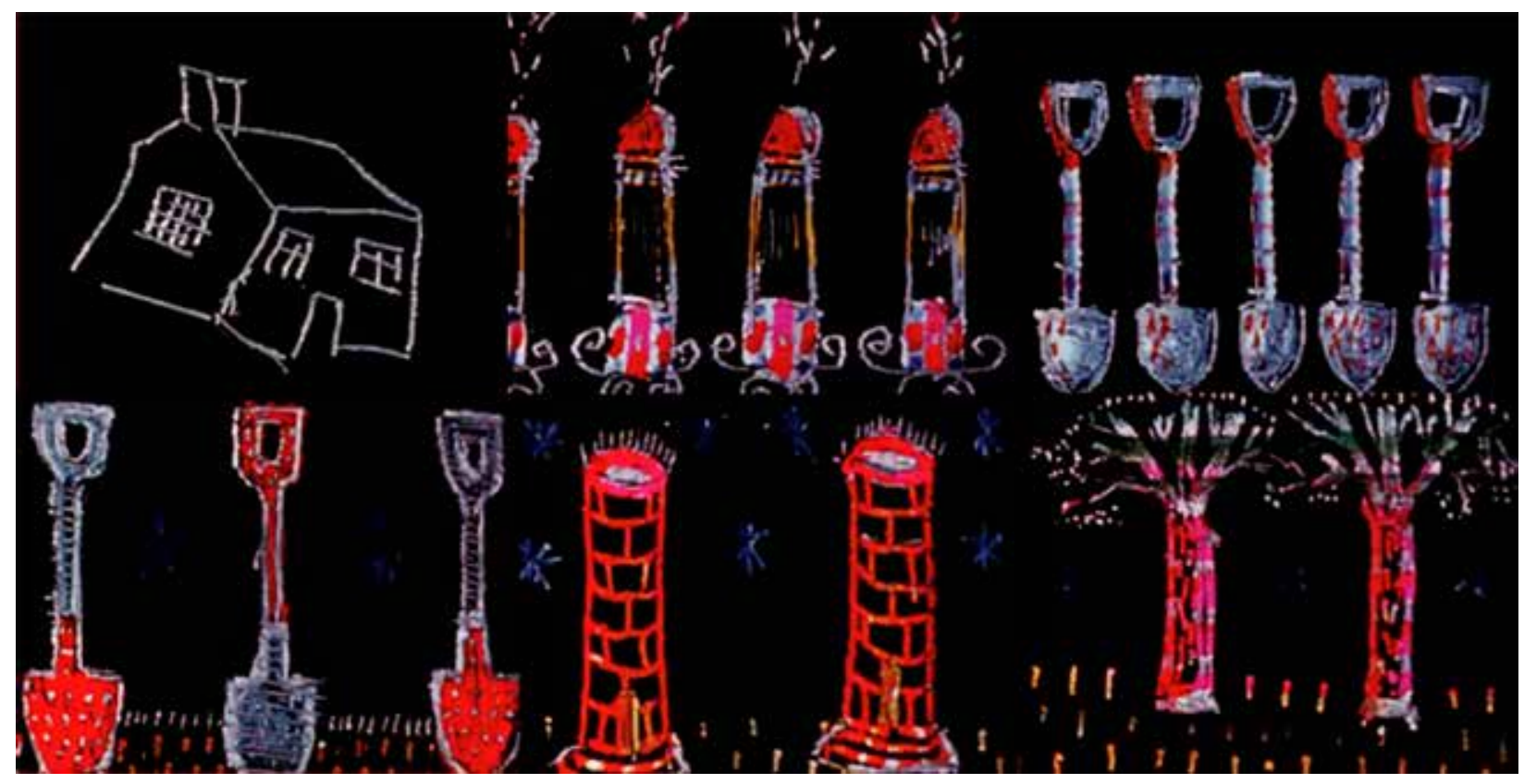

Figura 10 - Frames da animação Begone Dull Care (1949). Norman McLaren e Evelyn Lambart. Fonte: https://youtu.be/Or2COvWPO4Y

sobre a película, como o pente fino, para obter os mais diversos resultados. Trata-se de explorar a plástica do filme em sua tatilidade visual por meio da materialidade da mesma.

A técnica utilizada por McLaren na criação de Begone Dull Care foi o método que o artista mais utilizou durante sua carreira: o de animação direta sobre a película, anteriormente explorado pelo animador alemão Fischinger e pelo britânico Len Lye, ambos importantes nomes da animação experimental mencionados no capítulo anterior.

Foi McLaren, e essa animação é produto disso, que expandiu as possibilidades expressivas, estéticas e poéticas por meio de suas pesquisas com o referido método. Nessa técnica o animador pinta e desenha diretamente sobre o filme de película virgem $35 \mathrm{~mm}$ sem se utilizar de uma câmera. A ilusão de movimento é causada pelas pinturas feitas frame a frame na película projetadas em sucessão numa superfície plana.

A partir do diálogo entre o movimento das formas gráficas e o jazz feito pelo Oscar Peterson Trio, a expressão gráfica dos sons potencializam as possibilidades estéticas e expressivas da animação. O impacto da música e a dança das formas gráficas sincronizadas no curta fundem perfeitamente o som e a imagem, causando uma experiência estética sinestésica no espectador. A força expressiva aparece no gesto de McLaren e Lambart ao pintar e animar as imagens com o jazz, gênero musical de forte gestualidade, expressividade e improvisação cuja manifestação se deu junto com o movimento de arte moderna norte americano chamado Expressionismo Abstrato:

\begin{abstract}
Assim como se diz em pintura (na caligrafia oriental) que a qualidade da imagem é consequência direta do gesto do pintor, que se traduz em traço expressivo, também em música o material sonoro traz marcas do gesto que o engendrou. Nesse sentido, não seria um despropósito falar, no âmbito da música, de uma action playing, da mesma forma como se fala de uma action painting em artes plásticas (MACHADO, 2005, p.162).
\end{abstract}

Ao nomearem sua animação Begone Dull Care - o que em português podemos traduzir literalmente por Vá Embora Preocupação Tediosa - McLaren e Lambart brincam com sua obra e sua produção experimental em oposição às tradicionais animações comerciais. 0 improviso e as experimentações em detrimento de um plano rígido de execução e a união entre o jazz e as pinturas feitas diretamente sobre a película produzem uma animação vibrante que se afasta das tediosas animações comerciais. Begone Dull Care é fruto do incansável entusiasmo de McLaren pela experimentação e pelas imagens em movimento. 


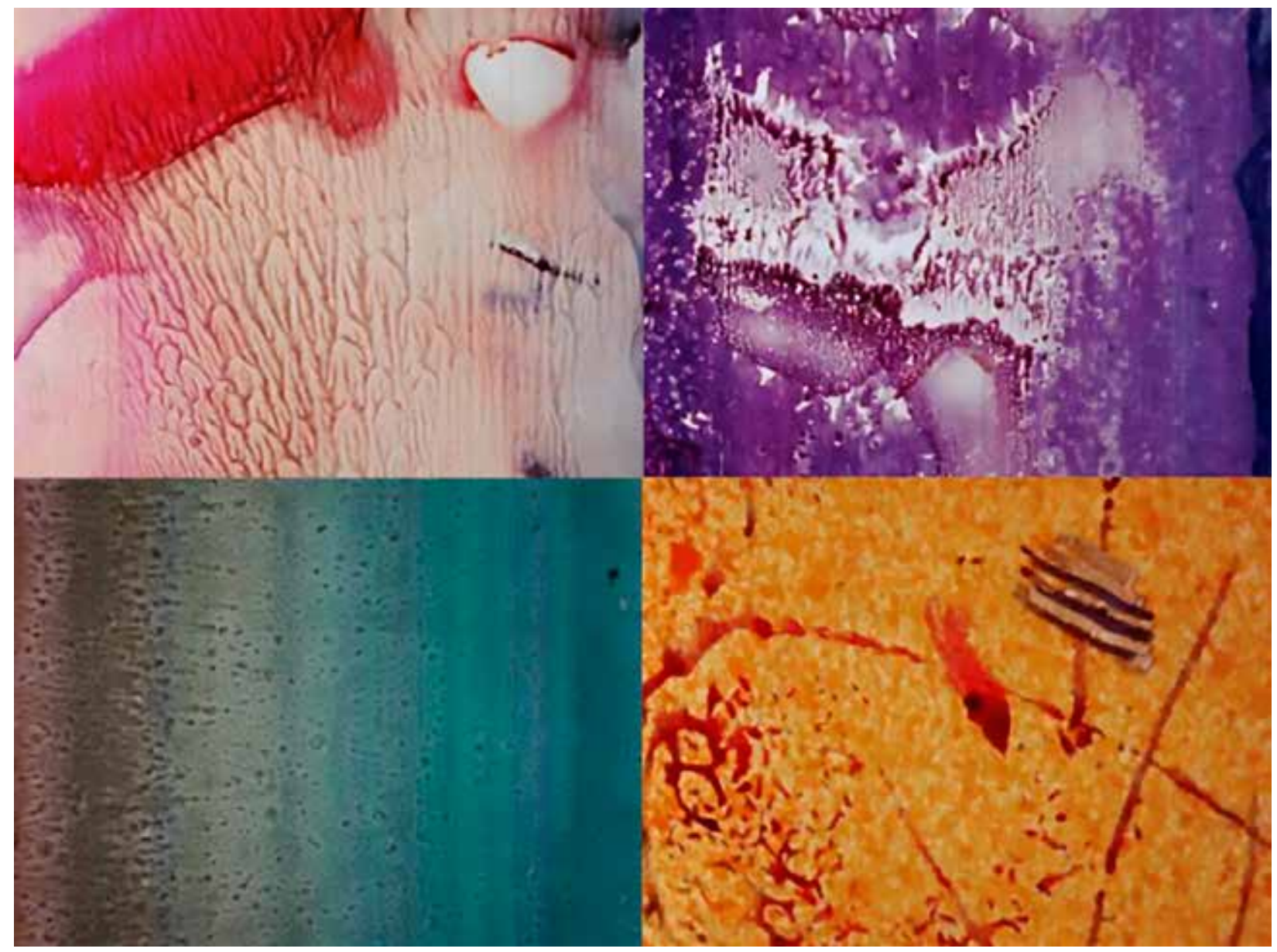

Figura 11 - Frames da animação Begone Dull Care (1949). Norman McLaren e Evelyn Lambart. Fonte: https://youtu.be/Or2COvWPO4Y

\section{CONSIDERAÇÕES FINAIS}

Embora tenhamos conseguido delimitar aspectos elementares da animação experimental tais como entusiasmo pelo novo ou desconhecido, afinidade com a criação artística, experimentação de novas e inusitadas técnicas para produção da animação sem a preocupação formal de facilitar o processo, caráter independente/autoral e fora dos grandes estúdios de animação tradicional, improvisação e/ou uso de acidentes e imprevistos como potencializadores expressivos sem se prender a um planejamento original e definitivo - cremos ser um tanto limitador tentar definir ou delimitar completamente a mesma.

Defendemos que o exercício experimental de McLaren está em sintonia com as pesquisas plásticas da arte abstrata a partir das quais os artistas de vanguarda imprimiam por meio da materialidade a discussão sobre o pictórico, a matéria como fonte da experiência tátil e visual, as relações entre o empaste e a espessura das massas que davam corpo a pintura e ainda opacidades, transparências e aspectos da forma e da cor que revelam a capacidade estética da materialidade em nos fazer sentir a textura e os códigos abstratos da imagem.

De igual forma, os animadores experimentavam inúmeros recursos diretamente sobre a película para explorar sua materialidade dando a ela status de matéria sensível.

As experimentações proporcionam à animação infinitas possibilidades que escapam de definições ou certezas e, desde o início do século XX, o cinema não para de se expandir e se hibridizar com outras linguagens como as visuais.

Em suma, os resultados alcançados com esta pesquisa e em parte aqui apresentados neste artigo se revelam uma contribuição aos estudos na área do cinema e da animação em interface com 
as artes visuais que esperamos incentivar novas investigações no campo interdisciplinar. Ao final, observamos que são poucos os que se dedicam ao tema e o levantamento histórico e de animadores presentes nas referências bibliográficas situamse dentro do eixo Europa - Estados Unidos.

\section{NOTAS}

1. Texto original: [...] an electroacoustic conversion of drawn, geometrical figures. (The IMA Institute of Media Archeology). Disponível em: <https:// ima.or.at/en/rudolf-pfenninger/>. Acesso em: 10 de fev. de 2018.

\section{REFERENCIAS}

ALKIMIM, Robson. A Arte Animada de Norman McLaren. In: Soul Art. Disponível em: < http:// soulart.org/cinema/a-arte-animada-denorman-mclaren/>. Acesso em: 01 de mar. 2018.

BARBOSA JÚNIOR, Alberto Lucena. Arte da Animação. Técnica e estética através da história. 2a ed. - São Paulo: Editora SENAC, 2005, 456p.

DENIS, Sébastien. 0 Cinema de Animação. Lisboa: Edições Texto \& Grafia, Lda., 2010.

GRAÇA, Marina Estela. Entre o Olhar e o Gesto; elementos para uma poética da imagem animada. São Paulo - SP: Editora SENAC, 2006. 222p.

MACHADO, Arlindo. A Televisão Levada a Sério. São Paulo: Editora SENAC, 2005, p.153-172.

MAGALHÃES, Marcos. Novos caminhos para a animação experimental. Rio de Janeiro - RJ: Revista Filme Cultura, n. 54, p.45-48, mai. 2011.

MIRANDA, Carlos A. Cinema de Animação: Arte nova, Arte livre. Petrópolis, RJ: Editora Vozes Ltda., 1971.

REIS, Marta. Animação Experimental: um universo de ideias revolucionárias. In: Mundo de Cinema. Disponível em: <http://mundodecinema. com/animacao-experimental/>. Acesso em: 24 de out. 2017.

RIBEIRO, Leonardo Freitas. 0 Ponto de Viragem: A animação brasileira, possíveis desdobramentos de um sonho industrial. 2012. 226p. Dissertação (Mestrado em Design) - Pontifícia Universidade Católica do Rio de Janeiro.

PFENNINGER, Rudolf. In: The IMA Institute of Media Archeology. Disponível em: <https://ima. or.at/en/rudolf-pfenninger/>. Acesso em: 10 de fev. de 2018.

RUSSET, Robert \& STARR, Cecile. Experimental Animation - An Illustrated Anthology. Nova York: Van Nostrand Reinhold Company, 1976. 224p.

TEIXEIRA, Iuri Araújo Cardoso. Batalha das Máscaras: Animação Experimental Digital Baseada nas Cavalhadas de Pirenópolis. 2015. 133p. Dissertação (Mestrado) - Universidade Federal de Goiás, Faculdade de Artes Visuais (FAV), Programa de Pós-Graduação em Arte e Cultura Visual, Goiânia.

\section{SOBRE OS AUTORES}

Regilene Aparecida Sarzi-Ribeiro é pós-doutora em Artes, pelo Instituto de Artes da UNESP/SP. Doutoraem ComunicaçãoeSemiótica pelaPUC/SP. Professora Assistente Doutora do Departamento de Artes e Representação Gráfica da Faculdade de Arquitetura, Artes e Comunicação da UNESP/ Bauru/SP. Docente permanente do Programa PPGMiT: Pós-Graduação em Mídia e Tecnologia da FAAC (UNESP/Bauru) na Linha de Pesquisa: Tecnologias Midiáticas. Docente colaboradora do Programa de Pós-Graduação em Artes do Instituto de Artes da UNESP/SP, na Linha de Pesquisa: Abordagens Teóricas, Históricas e Culturais da Arte. Líder do Grupo de Pesquisa labIMAGEM: Laboratório de Estudos da Imagem, credenciado no CNPq e certificado pela UNESP. Colíder do grAVA: Grupo de Pesquisa em Artes Visuais e Audiovisual (UNESP/FAAC/Bauru). Pesquisador dos Grupos de Pesquisa: Arte e Tecnologia (UFSM/RS) e GEA: Grupo de Estudos Audiovisuais (UNESP/FAAC/Bauru.). Membro da Diretoria, Biênio 2017-2108, da Associação Nacional de Pesquisadores em Artes Plásticas: ANPAP, onde compõe o Comitê História, Teoria e Crítica de Arte. Membro do Comitê Científico da Revista Educação Gráfica (UNESP/FAAC/Bauru). Membro do Comitê de Ética (Representação Docente dos 
Programas de Pós-Graduação) da FAAC/UNESP/ Bauru. Atua na área de Artes Visuais com ênfase para abordagens Transdisciplinares e História da Arte Brasileira e Latino-americana; Arte Contemporânea e Audiovisual, Teoria e Crítica das Artes do Vídeo e das Artes Audiovisuais, Corpo e Imagem-Performance, Arte Eletrônica e Tecno-Imagens. Como Artista Visual desenvolve trabalhos articulando o corpo às linguagens $d a$ fotografia e do vídeo, vídeo-pintura e videoarte.

João Víctor Kurohiji Bonani é bacharel em Artes Visuais da UNESP (FAAC). Participou do grupo de pesquisa em Teoria e História da Arte labIMAGEM Laboratório de Estudos da Imagem da FAAC, UNESP (2017-2018). Foi voluntário e bolsista na comissão de acervo da FAAC, UNESP (2017-2019). Bolsista de iniciação científica do CNPq (2017-2018). 


\section{CAMINHOS MARAJOARAS: O RIO ENQUANTO PAISAGEM, POÉTICA E POTÊNCIA ARTÍSTICA}

\section{Roseany Karimme Silva Fonseca CAPES/UFPA}

\section{Resumo}

Este artigo é resultante dos estudos da disciplina Cultura Amazônica: Uma Poética do Imaginário na Atualidade de Cultura-Mundo, do Programa de Pós-Graduação em Artes - PPGARTES/UFPa e objetiva traçar um paralelo entre três eixos de referências para os rios marajoaras, sendo estes: a paisagem, a poética e a potência. Através da descrição e do reconhecimento dos rios nos referidos eixos, propõe-se o encontro destes afluentes com o meu percurso enquanto artistapesquisadora de Artes neste lócus, definindo-o como espaço de identificações e criação artística.

\section{Palavras-chave:}

Marajó; Rio; Paisagem; Poética; Criação Artística.

\section{INTRODUÇÃO}

Existem muitas especificidades da região Amazônica que podem ser consideradas para a construção da cultura que identifica este local. Nesta região, cercada de ilhas e rios, há uma particularidade de climas, costumes e atividades. A bacia hidrográfica é uma idiossincrasia da região. Os rios, enquanto componentes de uma geografia comum no contexto amazônico, compõem-se como canais de passagem e equivalem às ruas dos centros urbanos; configuramse como as vias de acesso do viajante com outras localidades, às quais muitas vezes possuem somente acesso fluvial. Moreira (1989) considera que "em nenhuma outra região o rio assume tanta importância fisiográfica e humana como na Amazônia, onde tudo parece viver e definir-se em função das águas: a terra, o homem, a história" (p.63). De acordo com Oliveira (2006), a Amazônia é um lugar que pulsa modos de vida distintos do padrão caracterizado em outras regiões do Brasil.

Como um emblema amazônico, o rio tece não somente a geografia, como também o imaginário

\section{Abstract}

This article is a result from studies of discipline Amazon Culture: A Poetics of the Imaginary in Current World-Culture, from Program of PostGraduation in Arts - PPGARTES / UFPa and aims to draw a parallel between three axes of references for the Marajoara rivers, being these: the landscape, the poetics and the power. Through the description and recognition of the rivers in these axes, it is proposed the meeting of these tributaries with my path as an artist-researcher of Arts in this locus, defining it as a space of identification and artistic creation.

Keywords:

Marajó; River; Landscape; Poetic; Artistic Creation.

da região, dividindo-a em outras sub-regiões, com características bem definidas. Neste trabalho, será destacada dentro da Amazônia a região marajoara. Com suas características, o arquipélago marajoara destaca-se pelas vias fluviais, sua população e a forte relação de seus indivíduos com a paisagem que os cerca. Trindade Jr. (2005) caracteriza o reconhecimento das cidades localizadas nestes espaços:

faz-se necessário, assim, reconhecer a produção
do espaço beira-rio, sua história, suas vivências,
suas identidades, responsáveis por reforçar uma
especificidade da cidade na Amazônia, a cidade
ribeirinha-forma e conteúdo-, diferente da cidade
beira-rio, demarcada pela simples localização
às margens fluviais e pela presença do rio como
adereço da paisagem. (TRINDADE JR., 2005, p.11).

É importante reconhecer a própria existência enquanto indivíduo nestes lugares. Bachelard (1989) afirma que "se quero estudar a vida das imagens da água, preciso, portanto, devolver ao rio e às fontes de minha terra seu papel principal" (p.8). E por qual (ou quais) circunstâncias falar 
especificamente sobre os rios marajoaras? A ilha do Marajó ${ }^{1}$ é um cenário de vivências, memórias pessoais e viagens, que me permitiram absorver muitas experiências enquanto pessoa e atualmente, como artista-pesquisadora. Por sobre estes rios tracei observações e palavras através de várias viagens, construindo um diário de bordo, indutor da minha pesquisa de mestrado em andamento. Em sua dissertação, Keyla Sobral ${ }^{2}$ cita e caracteriza os diários de bordo: "Os diários de bordo se originaram com a navegação marítima. Antigamente [...] os navios continham um diário de bordo: que permitia à tripulação registrar tudo que acontecesse ao longo de uma viagem" (SOBRAL, 2015, p.23). A autora também correlaciona a ideia de fluxo dos rios com os percursos alcançados na escrita. Segundo ela: "Ser envolvida pelo fluxo dos rios, mas também pelo fluxo das palavras, que me acompanhavam durante as viagens, durante todo o percurso é fundamental. Estar em trânsito, sempre de passagem, e, sempre ser surpreendida pela palavra" (Ibidem, p.26).

Outra justificativa para este trabalho é a minha inserção enquanto aluna na disciplina Cultura Amazônica: Uma Poética do Imaginário na Atualidade de Cultura-Mundo, ministrada pelo professor João de Jesus Paes Loureiro ${ }^{3}$. Esta disciplina propõe apresentar reflexivamente a Cultura Amazônica por meio de sua mitologia, sua criação artística e seus processos criativos, percebendo esta cultura como fruto de uma região complexa e exemplo de diversidade diversa, que possui meandros de troca entre si e a chamada cultura-mundo. A referida disciplina me permitiu um aprofundamento em relação aos conceitos de paisagem, poética e imaginário, por onde se exerce a potência criadora, configurando desta forma os três eixos pelos quais pretendo descrever e localizar o rio neste trabalho, através das seguintes terminologias: rio-paisagem, riopoética e rio-potência.

\section{RIO-PAISAGEM}

Para abordar o que seria a terminologia de riopaisagem neste trabalho, faz-se necessário recorrer inicialmente a uma abordagem geográfica, a qual melhor explicita o conceito de paisagem ${ }^{4}$. De acordo com o caderno da região hidrográfica amazônica:
A Amazônia é conhecida por sua grande disponibilidade hídrica [...] entrecortando uma vasta região geográfica com rios, lagos e igarapés com grande variabilidade tanto na extensão, quanto na largura dos rios, bem como no volume de água por eles transportado (BRASIL, 2006, p. 24).

É importante destacar que a paisagem sempre esteve no limiar entre o caráter objetivo e subjetivo da observação; ou seja, é um conceito que dependendo do contexto, adquire interpretações mais simples ou complexas. Pensar a paisagem na geografia é diferente de pensar a paisagem na cultura, embora ambas se entrelacem. COLLOT (apud CABRAL, 2000) define três elementos fundamentais como constituintes do conceito de paisagem: o ponto de vista, a parte e a unidade. A paisagem é definida em função do ponto de vista de onde é observada: não como local autônomo, mas na relação constante entre sujeito/objeto. 0 segundo elemento define a paisagem como parte de um ambiente muito maior, esta parte apreendida pelo sujeito-observador que também é integrado ao espaço e por fim, a ideia de unidade: ainda que haja um recorte da paisagem, pelo ponto de observação, ela se constitui como um aspecto de totalidade. Assim, o rio-paisagem seria definido a partir do meu ponto de vista enquanto artistapesquisadora, através da observação da paisagem marajoara; seria uma parte de tudo o que a região do arquipélago do Marajó representa, a partir de características tão definidas quanto distintas entre si e constituiria a unidade, representada neste trabalho pela figura dos rios.

É preciso navegar meses inteiros nessa bacia gigantesca para compreender até que ponto é extraordinário aí o predomínio da água sobre a terra. Esse labirinto líquido é bem mais um oceano de água doce, cortado e dividido pela terra, do que uma rede fluvial (MOREIRA, 1989, P.64).

Embora a paisagem seja um conceito de maior recorrência nos estudos geográficos, este termo tem se desdobrado em diversas abordagens, permitindo amplas e diversas interpretações. Concebida como "uma parte da natureza reportada pelo olhar visível"5, a paisagem se divide em histórica, poética, psicológica, filosófica, entre outras áreas dentro de sua abrangência.

Paisagem é uma fonte incessante de significação e uma vez acessível ao olhar e à mente, torna-se guia para as ações e condutas humanas; não se trata de um horizonte fixo e estático, mas construído de movimento, valores e sentimentos. Ao incluir 
aquilo que tem significância para os diferentes sujeitos, a paisagem deixa de ser o pano de fundo das atividades e acontecimentos e integra-se à existência humana (CABRAL, 2000, p. 41 e 42).

De acordo com Coelho (2009): "a paisagem enquanto representação resulta da apreensão do olhar, é um enquadramento, uma seleção que existe a partir do indivíduo que organiza, combina e promove arranjos de conteúdo e forma" (p.4).

Se a paisagem é compreendida enquanto fenômeno, ou seja, um conjunto dinâmico, no qual o ser humano vive, desloca-se e busca por significados, ela não pode ser considerada isoladamente e nem ser dissociada de quem a vivencia. Deste modo, pode-se pensar o riopaisagem não unicamente enquanto componente geográfico, mas de acordo com Cabral (2000), "um conceito abrangente e impreciso [...] pois desse modo incita-nos a olhar para outros horizontes disciplinares a fim de ampliarmos e aprofundarmos a compreensão de sua natureza e significado" (p.35). A paisagem enquanto signo possui a função de produzir significados e em uma concepção humanista, o conceito prioriza as relações que os sujeitos possuem com seus entornos. A partir desta perspectiva, pode-se então desdobrar o próximo eixo de trabalho desta pesquisa, o rio-poética.

\section{RIO-POÉTICA}

\section{Cântico V}

\author{
Rio \\ de muitos nomes, \\ Ser \\ de muitas \\ de muitas formas e fomes. \\ Espelho contra espelho \\ rio só linguagem \\ rio sim sêmen de Deus. \\ Amazonas \\ água e lama \\ vogais e consoantes. \\ Que outro nome corre no teu leito, \\ se outro rio corre no teu nome? \\ Rio, superfície de si mesmo \\ e Mar além de si. \\ Água antes de si \\ (Inexistência)
}

(LOUREIRO, 2000, p.37).

No poema acima, o rio apresenta-se dotado de sentidos e metáforas, sendo caracterizado por uma observação de caráter poético. Esta representação da ideia de rio torna-o um lugar rico em signos interpretáveis de diversos outros modos. Loureiro (2008) define que a dimensão poética é capaz de tornar-se a função dominante em um texto escrito, quando este sai de seu sentido comum e passa a possuir um uso artístico, no qual a linguagem se desdobra, emergindo em poesia. No momento em que a paisagem sai de sua forma estética e abrange uma forma poética, há o que este autor chama de conversão semiótica, conceito criado e definido por ele como: o processo de mudança de função ou de significação dos fatos da cultura, quando se dá uma mudança de dominante, re-hierarquizando dialeticamente as outras funções. Na medida em que o rio deixa de ser unicamente visto como via de acesso entre a capital Belém e as localidades marajoaras e passa a ser matéria-prima de poemas, canções, entre outras formas artísticas, há uma variação de dominância: de paisagem à poética. Deste modo, atribui-se um caráter subjetivo e metafórico ao que antes era um conceito geográfico e estético. Conferem-se outros conteúdos às formas já existentes.

Desse modo, a água nos aparecerá como um ser total: tem um corpo, uma alma, uma voz. Mais que nenhum outro elemento talvez, a água é uma realidade poética completa. Uma poética da água, apesar da variedade de seus espetáculos, tem a garantia de uma unidade. A água deve sugerir ao poeta uma obrigação nova: a unidade de elemento (BACHELARD, 1989. p. 17).

Para definir a nomenclatura rio-poética, é importante verificar não somente o conceito de poética, mas a forma como este conceito se constitui na paisagem ribeirinha. É conhecida a ideia das águas como indutoras de poemas, textos, canções e outras formas de criação artística. $\mathrm{Na}$ obra A Água e os Sonhos (1989)6, o autor Gaston Bachelard define a cultura amazônica como uma região mítica e folclórica, atribuindo também tais questões ao ser que observa as paisagens líquidas, "que vê passar a água" e "evoca a origem legendária do rio, sua fonte longínqua" (BACHELARD, 1989, p.158). Este autor destaca a contemplação da paisagem como forma de alcançar uma criação poética: "não posso sentar perto de um riacho sem cair num devaneio profundo [...] Não é preciso que seja o riacho da nossa casa, a água da nossa casa. A água anônima sabe todos os segredos. A mesma lembrança sai de todas as fontes" (Ibid, p.9). Desta forma, o rio torna-se um ambiente de devaneios por sua força 
e onipresença na paisagem amazônica - e mais especificamente, no arquipélago marajoara. Em "Meditação Devaneante entre o Rio e a Floresta"7, Loureiro (2016) tece uma observação poética dos rios amazônicos, não somente da paisagem em si, mas dos olhos de um observador, ou seja, de uma percepção que comporta múltiplas possibilidades.

Na linha da ribanceira, entre o rio e a floresta, estão os arquivos da vida amazônica. É uma verdadeira escola do olhar. Uma pedagogia da contemplação. Um aprender a aprender olhar. O olhar que experimenta a vertigem de uma alma errante. $\mathrm{Na}$ margem do rio e da floresta irrompe a vida, em duplo. É o reino das ambiguidades e da semovência de contornos (LOUREIRO, 2016, p. 127).

De acordo com Lynch (2011): "nada é vivenciado em si mesmo, mas sempre em relação com seus arredores e com as sequências de elementos que a ele conduzem, bem como às lembranças de experiências passadas" (p.1). Portanto, a percepção mostra-se fundamental para que a paisagem se desenvolva através de um olhar poético. Pensando por esta perspectiva, podese inferir que não há nada na paisagem que não permita um olhar mais atento para uma criação poético-artística.

Revelando uma afetividade cósmica, o homem promove a conversão estetizante da realidade em signos, por meio dos labores do dia-a-dia, do diálogo com as marés, do companheirismo com as estrelas, da solidariedade dos ventos que impulsionam as velas, da paciente amizade dos rios (LOUREIRO, 2016, p. 73).

Atribuir poética ao rio seria atribuir-Ihe uma gama de significados, interpretações e sentidos, os quais não seriam possíveis somente com a observação da forma, mas com uma atenção especial ao seu conteúdo e também, ao trajeto antropológico ${ }^{8}$ de seu observador. Segundo Cabral (2000):

tomar a paisagem como campo de significação é concebê-la como encontro de lógicas provenientes de diferentes escalas (individuo-grupo-sociedade). Lógicas essas, determinantes e determinadas pelos diferentes atores sociais que interagem e se apropriam diferentemente da paisagem. (CABRAL, 2000, p. 42)

Para o artista-criador - seja através de palavras, imagens, traços ou outras formas de arte - a paisagem deixa de existir unicamente em sua forma (sua função estética) e passa a exprimir um conteúdo (sua função poética). Escrever o diário de bordo me permitiu transformar o riopaisagem em rio-poética. Mas nenhuma destas terminologias existiria se não houvesse a potência criadora, ou seja, a motivação. "Ao incluir aquilo que tem significância para os diferentes sujeitos, a paisagem deixa de ser o pano de fundo das atividades e acontecimentos e integra-se à existência humana" (Ibidem, p.42). Pela minha vivência e história com a região marajoara, fui instigada a buscar potência para a paisagem, através de uma poética.

Perceber o caráter quase sempre feminino atribuído à água pela imaginação ingênua e pela imaginação poética [...] a água faz incharem os vermes e jorrarem as fontes. A água é uma matéria que vemos nascer e crescer em toda parte. A fonte é um nascimento irresistível, um nascimento contínuo. Imagens tão grandiosas marcam para sempre 0 inconsciente que as ama. Suscitam devaneios sem fim (BACHELARD, 1989, p.15).

\section{RIO-POTÊNCIA}

A terminologia rio-potência apresenta-se de forma didática neste trabalho, sendo considerada uma forma de aproximar os dois conceitos anteriores - riopaisagem e rio-poética - através de uma intersecção de ideias, haja vista que nenhum dos dois conceitos pode ser desconsiderado ao tratar da ideia dos rios enquanto potência e indução para a criação artística.

Sob o olhar do natural, a região se torna um espaço conceptual único, vago, mítico, irrepetível (posto que cada parte desse espaço não é igual a outro), próximo, e ao mesmo tempo, distante. Seja para os que habitam as margens desses rios, que parecem demarcar a mata e o sonho, seja para os que habitam a floresta (LOUREIRO, 2016, p.128 e 129)

É importante destacar que o processo de criação artística ocorre quando há a transformação de um conteúdo que aparentemente não é artístico em algo artístico, ou seja, quando já existe a forma e ela impregna-se de conteúdo. Salles (2006), define este processo de criação como um registro dinâmico:

Devemos pensar, portanto, a obra em criação como um sistema aberto que troca informações com seu meio ambiente. Nesse sentido, as interações envolvem também as relações entre espaço e tempo social e individual [...] envolvem as relações do artista com a cultura, na qual está inserido e com aquelas em que ele sai em busca. A criação alimenta-se e troca informações com seu entorno em sentido bastante amplo. (SALLES, 2006, p. 32)

Aí reside um caráter potente no objeto ou na paisagem, exemplificada aqui pelos rios marajoaras. Quando eu, enquanto observadora, crio um diário de bordo em meio às viagens nestes rios, extraio todo 
um significado/conteúdo para a forma escrita que já existe e o rio-paisagem torna-se rio-poética através de sua própria potência indutora. É importante que o artista, por questões criativas, alcance a sociedade e estenda-se para fora dela, levando, pela produção poética, a sua alma visível ao convívio universal. Ao conferir potência a uma paisagem, compõem-se uma série de significantes/significados, os quais podem ser explicitados através da obra artística. No poema "Fragmento"9, é evidente a presença e potência do lugar na construção artística, não somente por seu espaço concreto, mas pelas percepções e interpretações de seu observador:

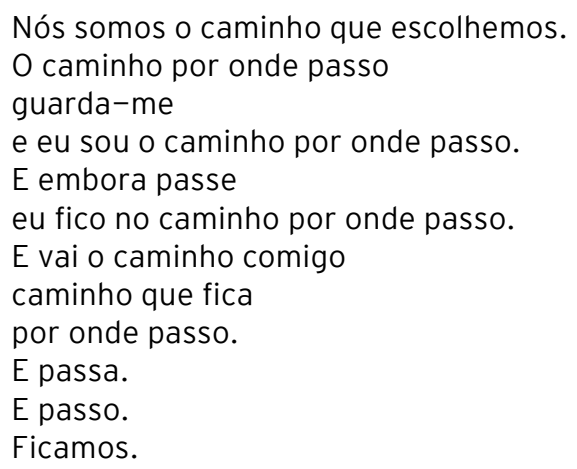

(LOUREIRO, 2017, p. 54 e 55)

\section{ENCONTRO DE AFLUENTES}

Tomo a liberdade de inserir a terminologia de "encontro de afluentes" ao invés de "considerações finais" na parte conclusiva este trabalho. Os três eixos definidos aqui se complementam em minha observação enquanto artista, pesquisadora, viajante e na feitura do diário de bordo como indução para as paisagens dos rios marajoaras. Eles vem se desenhando como caminhos possíveis de experimentação poético-cênica. A disciplina Cultura Amazônica: Uma Poética do Imaginário na Atualidade de Cultura-Mundo me permitiu um aprofundamento - literal e figurado - em meu processo de pesquisa, além de pensar a cultura local como um lócus tão importante e potente quanto a chamada culturamundo. Parafraseando o professor e autor Paes Loureiro: não há nada insignificante que não possa ser significado. Concluo este percurso com um poema de Augustin Berque (1998), que compreendo ser uma síntese de tudo o que vem sendo abordado neste trabalho, sobre paisagem:

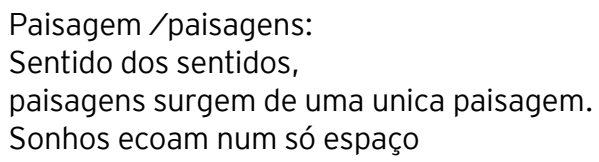

Acordam realidades: complexas, ambivalentes, ambíguas.

Realidades que desvelam não só as inúmeras faces da paisagem,

mas a busca do "olho" por um significado, por uma leitura,

por um lugar onde a atenção despendida traduza ordem, sentido, valor, identidade.

Paisagens são perspectivas!

São espelhos que refletem nossos sentimentos e pensamentos, anseios e medos.

Nossa individualidade na individualidade do entorno. Armazenadas na memória e na alma...

antes de serem efêmeras, paisagens são duradouras...

antes de comporem apenas quadros e cartões postais,

são "substâncias" que integram e animam nossas vidas.

\section{NOTAS}

1. A ilha do Marajó integra o maior arquipélago fluvio-marinho do mundo e se localiza na foz do Rio Amazonas. A ilha é composta por 12 municípios - Cachoeira do Arari, Chaves, Muaná, Ponta de Pedras, Santa Cruz do Arari, Salvaterra e Soure (sendo que estes municípios compõem a chamada microrregião dos campos), além de Afuá, Anajás, Breves, Curralinho e São Sebastião da Boa Vista (os quais compõem a microrregião dos furos). Na minha pesquisa, foi considerada a paisagem dos rios que banham as cidades de Salvaterra e Soure, lugares nos quais foi confeccionado o diário de bordo enquanto modo de observação da paisagem.

2. Keyla Sobral utilizou seus diários de bordo como indutores de sua pesquisa na dissertação de mestrado intitulada "Fluxo Norte: sobre diários de bordo e cartografia poética de determinada produção de artes visuais na Amazônia.", apresentada e defendida no PPGARTES/UFPA, no ano de 2015.

3. João de Jesus Paes Loureiro é poeta, doutor em Sociologia da Cultura, ensaísta, teatrólogo e professor da Universidade Federal do Pará. No programa de Pós-Graduação em Artes (PPGARTES/UFPA), ministra atualmente a disciplina Cultura Amazônica: Uma Poética do Imaginário na Atualidade de CulturaMundo, nos cursos de Mestrado e Doutorado.

4. Etimologicamente, o vocábulo em português provém do francês paysage e apresenta na definição do lexicógrafo FERREIRA (1989, p. 1018), conotações vinculadas à percepção espacial e à arte: "1. Espaço de terreno que se abrange num 
lance de vista. 2. Pintura, gravura ou desenho que representa uma paisagem natural ou urbana."

5. Conceito atribuído à Paisagem nos estudos da disciplina Cultura Amazônica.

6. BACHELARD, Gaston. A Água e os Sonhos ensaio sobre a imaginação da matéria. São Paulo: Martins Fontes, 1989.

7. Texto publicado na Revista Arteriais, em agosto de 2016.

8. Trajeto antropológico é um conceito definido por Gilbert Durand (1989) como "a incessante troca que existe no imaginário entre as pulsões subjetivas e assimiladoras e as intimações objetivas que emanam do meio cósmico e social" (p.29). Pode-se dizer que este trajeto representa a ligação entre o mundo externo e as questões internas de quem o observa, sua história de vida.

9. Poema de João de Jesus Paes Loureiro, publicado na obra "À Beira do Rio, À Beira do Mundo." (2017).

\section{REFERÊNCIAS}

BACHELARD, Gaston. A água e os sonhos: ensaio sobre a imaginação da matéria. $1^{a}$ edição. São Paulo: Martins Fontes, 1989.

BERQUE, Augustin. Paisagem-marca, paisagemmatriz: elementos da problemática para uma geografia cultural. In: CORREA, Roberto Lobato e ROSENDAHL, Zeny (orgs.). Paisagem, tempo e cultura. Rio de Janeiro: Editora da VERI, 1998. p. 84-91.

BRASIL, Ministério do Meio Ambiente. Secretaria de Recursos Hídricos. Caderno da Região Hidrográfica Amazônica / Ministério do Meio Ambiente - Brasília: MMA, 2006.

CABRAL, Luís Otávio. A paisagem enquanto fenômeno vivido. IN: Geosul, Florianópolis, Vol. 15, n 30, p 34-45, jul./dez, 2000.

COELHO, Letícia Castilhos. A paisagem na fotografia, os rastros da memória nas imagens. In: XIII ENANPUR - Encontro Nacional da Anpur, 2009, Florianópolis. XIII Encontro Nacional da ANPUR, 2009.

DURAND, Gilbert. As estruturas antropológicas do imaginário. Trad: Hélder Godinho. Lisboa Editorial Presença, 1989.
FERREIRA, Aurélio Buarque de Holanda. Novo dicionário da Língua Portuguesa. Rio de Janeiro: Nova Fronteira, 1984.

LOUREIRO, João de Jesus Paes. À Beira do Rio, à Beira do Mundo. Belém: UFPA, 2017. João de Jesus Paes. Meditação devaneante entre o rio e a floresta. Arteriais - Revista do Programa de Pós-Graduação em Artes, p. 120-132, out. 2016. ISSN 2446-5356. Disponível em <http://www.periodicos.ufpa.br/ index.php/ppgartes/article/view/3924/3905>. Acesso em: 04 nov. 2018. João de Jesus Paes. A arte como

encantaria da linguagem. São Paulo: Escrituras Editora, 2008. , João de Jesus Paes. Obras reunidas (3.vol.). São Paulo: Escrituras Editora, 2000.

LYNCH, Kevin. A imagem da cidade. São Paulo: Editora WMF Martins Fontes, 2011.

MOREIRA, Eidorfe. Obras Reunidas - volume 1. Belém: Editora Cejup, 1989.

OLIVEIRA, José Aldemir de. A cultura, as cidades e os rios na Amazônia. Cienc. Cult. [online]. 2006, vol.58, n.3, pp.27-29. ISSN 2317-6660.

SALLES, Cecilia Almeida. Redes da Criação construção da obra de arte. São Paulo: Editora Horizonte, 2006.

TRINDADE JR, Saint Clair. Grandes Projetos, Urbanização do Território e metropolização da Amazônia. In: X Encontro de Geógrafos da América Latina, São Paulo, 2005.

\section{SOBRE A AUTORA}

Roseany Karimme Silva Fonseca é mestranda do Programa de Pós-Graduação em Artes (PPGARTES/ UFPa), na linha de Poéticas e Processos de Atuação em Artes. Bolsista CAPES. Pesquisadora associada à Associação Brasileira de Pesquisa e Pós-Graduação em Artes Cênicas / ABRACE. Possui experiência na área de Artes com ênfase em Teatro, Dramaturgia, Encenação e Processos de Criação; experiência na área de Psicologia, com ênfase em Psicologia Escolar, Psicopedagogia e Desenvolvimento Humano. 


\title{
A CASA ONDE COM ELA ESTAMOS - ESCRITA, TORÇÃO E VERTIGEM (OU SOBRE QUANDO O AUTOBIOGRÁFICO É ATO BIOGRÁFICO)
}

\author{
Luciana Brandão Carreira \\ UEPA
}

\section{Resumo}

A aposta de que se trata nesse trabalho visa sustentar que a escrita cumpre funções diferentes, para diferentes sujeitos, em diferentes momentos. É nessa direção que acreditamos que Clarice Lispector fez de seu exercício de escriba o próprio manejo implicado no refazer de seu corpo, enlaçandose, através do ato de escrever, pulsionalmente a uma língua. Essa perspectiva adotada a respeito da escrita nos permite destacar um importante aspecto a ela relacionado, pois julgamos que vida e obra são vertentes indissociáveis na produção de um estilo, não somente para um escritor, mas para todo artista.

\section{Palavras-chave:}

Ato criativo; autobiografia; escrita.

... não compreendo o que vi. E nem mesmo sei se vi, já que meus olhos terminaram não se diferenciando da coisa vista. Só por uma anomalia na continuidade ininterrupta de minha civilização, é que por um átimo experimentei a vivificadora morte. A fina morte que me fez manusear o proibido tecido da vida. Clarice Lispector.

O dia era pesado, bom e vazio. Pretendendo torná-lo o mais longo possível, a mulher retira o telefone do gancho, assegurando-se de que nada a perturbaria.

O que virá se passará no intervalo de tempo de 1 hora - entre as 10 e 11 horas da manhã de um dia que tinha tudo para ser como um outro dia qualquer. Todo o porvir condensado nesse intervalo temporal, nessa suspensão em que o tempo para. Tudo nesse hiato, entre-duas-mortes, através da narrativa desconcertante da protagonista, que

\section{Résumé}

L'objectif de cet article est de maintenir que l'écriture remplit différentes fonctions pour différents sujets et à différentes époques. C'est dans cette direction que nous sommes convaincus que Clarice Lispector s'est confiée à l'exercice de scribe la manipulation même impliquée dans la refonte de son corps, s'entremêlant, à travers l'acte d'écriture, pulsionnément à une langue. Cette perspective de l'écriture nous permet de mettre en évidence un aspect important, car nous pensons que la vie et le travail sont des volets indissociables de la production d'un style, non seulement pour un écrivain, mais pour chaque artiste.

Mots-clés:

Acte créatif; autobiographie; écriture.

tenta transmitir a experiência que a fará perder por horas e horas a sua forma humana.

Escultora de origem burguesa, ela é adequada ao que socialmente esperam que ela seja. Sozinha em seu apartamento, ela decide arrumá-lo, começando pelo quarto dos fundos que, até a véspera, era ocupado pela empregada doméstica que se demitira após seis meses de trabalho naquele espaço. Ali ela estava: uma solitária mulher anônima, rica e solteira por opção, logo após ter sofrido um aborto, cujo nome é reduzido à impessoalidade de duas letras: $G$. H.

E quanto a nós, onde estamos? Estamos no primeiro capítulo de $A$ paixão segundo $G$. H., talvez o livro mais célebre de Clarice Lispector. Nós, seus leitores, convidados a entrarmos com ela nessa Casa, nesse tempo, capturados pela descrição de 
uma experiência forjada pela narradora que nos expande e, de imediato, atordoa-nos - pois nessa Casa, "o fato de ninguém falar ou andar e poder provocar acontecimentos alargava em silêncios" (Lispector, [1964] 1998a, p. 24).

Através da leitura, abre-se esse espaço no qual o leitor é jogado, de cara, no ponto ínfimo e máximo do relato de uma mulher que viu algo e, que, sem saber do que se tratava, confundiu-se com isso que fora visto, fazendo que sejamos lançados no nada, no vazio, junto com a narradora. Algumas páginas adiante, ela continua: "Terá sido o amor o que eu vi? Mas que amor é esse tão cego como o de uma célula-ovo? foi isso? aquele horror, isso era amor?" (Lispector, [1964] 1998a, p. 19).

Sobre o estatuto dessa visão, retomamos a leitura do Seminário 11 (1964) - Os quatro conceitos fundamentais da psicanálise, quando Jacques Lacan discorre a respeito do olhar, através da experiência que o faz distingui-lo da visão e afirmar o quanto somos na verdade olhados por um quadro quando o contemplamos. Capturados por uma luz que nos chega do exterior, somos então inseridos na pintura, e, ainda que espectadores, por ela somos olhados por todos os lados. Com isso, fazemo-nos parte da tela, revolvemo-nos a partir dela. Os termos dentrofora são, portanto, redimensionados. O leitor, espectador de uma narrativa -, certamente também está susceptível a uma experiência desta natureza, passível de vir a ser sorvido pelo texto justo nesse ponto que se presentifica por meio de uma imagem muito particular. Imagem cujo estopo permite com que sejamos por ela fotografados, através do olhar, seu instrumento. Por conseguinte, a escrita que importa situar é essa escrita que faz cortes, que impõe um nó à estrutura da narrativa, que transpõe nesta os traços significantes inerentes a uma perda, que dispõe, ao leitor, um confronto possível com o impossível, e que o põe, inadvertidamente, às voltas com um saber sobre o verdadeiro. Uma escrita limítrofe, por assim dizer, promovedora da experiência do inconsciente, por isso vertiginosa.

Nas adjacências do que não pode ser dito, a narrativa segue entrecortada por pedaços fulgurantes de uma imagem vazada do enredo, refratária ao enunciado, desvinculada de um referente. Uma imagem movediça que se insurge como um pedaço desfalcado do texto, emaranhada na palavra apenas como subterfúgio para fazer nascer dali o olhar.
Sim, acreditamos que Clarice Lispector apresenta de maneira privilegiada o artifício que mantém a pulsação de um nome constituído pelo ato de escrever. Ela nos apresenta uma modalidade de escrita cuja textualidade podemos situar no campo das Lituraterras: espécie de escrita de borda, bemsucedida em face ao indizível e ao limite do que a linguagem pode vir a representar.

Quando Jacques Lacan propõe no Seminário 19 (1971-1972) que "o suporte do que se articula do discurso é o corpo", ele nos possibilita pensar que o estilo de um autor está sempre por referência ao que de seu corpo pôde ser transposto numa escrita, aproximando-se daquilo que o próprio Lacan afirma em Lituraterra sobre os restos inassimiláveis que do autor se depositam numa obra. Considerando que tais restos dizem respeito aos restos corporais, passíveis de sustentarem um discurso que não seria do semblante -, podemos dizer que à beira da morte Clarice Lispector recria, definitivamente, um lugar para se alojar na literatura.

Parodiando Lacan quando ele comenta que Velásquez não pinta em As meninas uma representação, e sim "o próprio ato de pintar", podemos também dizer que Clarice Lispector não escrevia simplesmente signos lingüísticos (como de fato são as palavras), pois ela "escrevia o próprio ato de escrever". Ela indica, através da estrutura de seu texto, que uma espécie de transliteração entre escritura psíquica e escrita textual se coloca a fim de tentar sobrepujar um ponto de impossibilidade existente no cerne da língua materna, espécie de furo inerente a algo ainda sem nome, que sempre se repete como impossível. Tangenciando uma estrangeiridade ao simbólico, Clarice Lispector testemunha (e mostra) o exílio que se dá nesse ponto onde o Real pulsional promove uma inscrição primeira; ou seja, a inscrição da impossibilidade de tudo se escrever - a inscrição de uma falta estrutural (e estruturante) $\uparrow$, quando ao regime da voz o objeto olhar vem se sobrepor. Trata-se de uma torção que bascula o indizível, promovendo que algo se imponha como uma mostração; tal como uma epifania mística a qual se revela uma imagem no ponto onde a narrativa esbarra em um limite, numa superação do falar em prol do mostrar.

Clarice Lispector indica o lugar inerente à própria topologia do sujeito, lá onde este soergue, na sua Casa. 


\section{O GESTO-VERTIGEM:}

A maneira como $\mathrm{G}$. $\mathrm{H}$. visa explorar espacialmente a arrumação da casa, apoderando-se assim do lugar que habita, aponta, desde o começo do romance, a uma subversão temporal que será recorrente ao longo de todo o texto: ela escolhe começar pelo fim, pelo quarto dos fundos, parte terminal do apartamento. E pretende finalizar pelo começo; ou seja, pelo living, a sala de estar, local que remete ao convívio social, onde primeiro se chega ao se adentrar um lar.

Para ter acesso ao quarto ela primeiro precisou atravessar toda a cozinha, chegando à área de serviço, em cujo final encontrava-se um corredor que ela também precisou percorrer, para finalmente encontrar o quarto dos fundos, chamado por ela de a "cauda do apartamento". Todavia, antes de ali entrar, uma pausa: G. H. encosta-se na murada da área de serviço para fumar um cigarro. É quando essa mulher olha para baixo, na vertigem dos treze andares que "caíam do edifício", comparando a verticalidade do prédio que habita a um despenhadeiro que engolirá em silêncio o cigarro que, num gesto proibido, ela imediatamente lançará ao solo.

O cigarro cai, é jogado para fora, descartado.

A topologia desse ponto em que G. H. está é nesse momento circunscrita: fora do quarto, mas dentro do apartamento onde mora, ela se põe a olhar a área interna do prédio. Ela olha a área interna, ou seja, o fundo dos apartamentos para os quais o seu apartamento também se via como fundos. Descrevendo o seu prédio, ela diz sobre esse dentro-fora:

por fora meu prédio era branco, com lisura de mármore e lisura de superfície. Mas por dentro a área interna era um amontoado oblíquo de esquadrarias, janelas, cordames e enegrecimentos de chuvas, janela arreganhada contra janela, bocas olhando bocas. O bojo de meu edifício era como uma usina. A miniatura da grandeza de um panorama de gargantas e canyons: ali fumando, como se estivesse no pico de uma montanha, eu olhava a vista, provavelmente com o mesmo olhar inexpressivo de minhas fotografias (Lispector, [1964] 1998a, p. 35).

A dimensão espacial é mais uma vez trazida à tona. Os termos dentro-fora impõem-se, em um desdobramento contínuo do espaço. Porém, uma vez que o espaço de que se trata é o corpo (e o corpo equivale ao espaço möebiano), lembremos que verso e anverso são determinados por uma torção promovida simplesmente pelo tempo que se leva para que ela se realize. A alternância entre os movimentos dentro-fora é determinada, portanto, por um acontecimento temporal. Por um átimo no qual se vive "a experiência vivificadora da morte" (Lispector, [1964] 1998a, p. 15).

Embora ofuscada pela entrada no cômodo desabitado, G. H. está disposta a começar o seu trabalho. Por onde? Ela desconhece. Examina o quarto com os olhos, quando percebe que o seu vazio seco é interrompido por alguns poucos objetos: uma cama, três valises de viagem e um guarda-roupa.

A cama estava nua, sem os lençóis que a recobriam, exibindo um colchão de pano empoeirado, manchado de sangue e suor. Num dos cantos do quarto, avistava-se o empilhamento simétrico de três maletas velhas em cujas superfícies de couro encontrava-se a marca praticamente apagada das iniciais de seu nome, as letras G. H.

Duas letras, os restos de um nome, uma assinatura.

O guarda-roupa, esse era estreito e da altura exata para que o corpo de G. H. nele coubesse. Ele estava ressecado pelo sol, rachado e com fissuras, gretas e farpas. Isto porque Janair - essa outra mulher, sua ex-empregada - manteve a única janela do quarto permanentemente aberta, permitindo que a luz solar deixasse ali as suas marcas $\$$ marcas que também correspondem aos seus restos $\Psi$; ali, na madeira do guarda-roupa da patroa. Uma janela aberta que descortina o real, expondo o ser a uma experiência limite. Originária, essa experiência diz respeito ao átimo no qual se vive a morte, quando as chagas da castração fundam o corpo (esse mero efeito de corte) e a pulsão de morte faz marca na pele. Atordoante porque rompe o sentido, essa experiência provoca uma torção corporal (e, por que não dizermos, espacial?) que impele à feitura de uma borda simplesmente para que se estanque o excesso que aí se produz. Os termos dentro-fora funcionam integrados, bem como tudo o que é inerente à dialética do ver / ser visto que deles deriva. Quando o estranho penetra no familiar através de um furo que se institui no campo da linguagem, a experiência que se vive é vertiginosa, pois ela implica o movimento de ir e vir até onde mais longe se possa chegar frente ao real. Por isso atordoa. 
Atônita com o que vê, G. H. vivencia um estranhamento, sendo levada a questionar o local onde vivia e a vida que levava. Como se estivesse em jogo a descoberta de um território estrangeiro na intimidade de sua própria casa, que a faz ver a realidade para a qual antes dessa experiência ela esteve fechando os olhos:

O quarto divergia tanto do resto do apartamento que para entrar nele era como se eu antes tivesse saído de minha casa e batido na porta. O quarto era o oposto do que eu criara em minha casa, o oposto da suave beleza que resultara de meu talento de arrumar, de meu talento de viver, o oposto de minha ironia serena, de minha doce e isenta ironia: era uma violentação das minhas aspas, das aspas que faziam de mim uma citação de mim. O quarto era o retrato de um estômago vazio (Lispector, [1964] 1998a, p. 42).

Nesse momento da narrativa, encontramos uma nova subversão espacial, com as dimensões dentro-fora uma vez mais redimensionadas:

E nada ali fora feito por mim. No resto da casa o sol se filtrava de fora para dentro, raio ameno por raio ameno, resultado do jogo duplo de cortinas pesadas e leves. Mas ali o sol não parecia vir de fora para dentro: lá era o próprio lugar do sol, fixado e imóvel numa dureza de luz como se nem de noite o quarto fechasse a pálpebra. Tudo ali eram nervos seccionados que tivessem secado suas extremidades em arame [...] o quarto me incomodava fisicamente como se no ar ainda tivesse permanecido o som do riscar do carvão seco na cal seca. O som inaudível do quarto era o de uma agulha rodando no disco quando a faixa da música já acabou (Lispector, [1964] 1998a, p. 43).

Por diversas ocasiões Lacan nos indicou o que descrevemos acima por meio de um curioso neologismo em que joga com os termos publicação e lixeira (poubellication) ${ }^{1}$, condensando-os em um equívoco na língua francesa. Ressaltemos que Lacan, em sua lição intitulada Lituraterra, faz justamente letra e lixo se equivalerem, ao deslizar o significante letter em litter, na mesma lição em que ressalta o fato de um certo tipo de literatura ser, na verdade, uma acomodação de restos, de pequenos dejetos ou detritos do escritor depositados em um escrito (Lacan, [1971] 2009, p. 106).

Consequentemente, uma publicação dessa natureza cumpriria a função de jogar na lixeira o gozo residual de quem escreve - gozo desprendido do objeto a quando ele é distanciado do corpo do escritor -, pois se trata de um gozo inútil, cujo único valor é o de fazer renascer "na transmissão e reatar, pela leitura, o real da vida ao imaginário do corpo e ao simbólico do puro traço. É no corpo que encontramos a causa da literatura, do texto, da obra" (Caldas, 2007, p. 59-60). Logo, uma vez que para Clarice Lispector o exercício de escrever tem o estatuto de um ato, a obra perfaz-se simplesmente tal como um resto corporal do qual o escritor precisa se separar.

Por que publicar o que não presta? Porque o que presta também não presta. Além do mais, o que obviamente não presta sempre me interessou muito. Gosto de um modo carinhoso do inacabado, do malfeito, daquilo que desajeitadamente tenta um pequeno vôo e cai sem graça no chão (Lispector, 1999c) ${ }^{2}$.

Quando indagada sobre a leitura de seus livros, Clarice respondeu: "quando é publicado, é como livro morto. Não quero mais saber dele. $E$ quando eu leio, estranho, acho ruim. Aí não leio, ora!" (Lispector, 1999c). Numa carta enviada ao amigo Lúcio Cardoso, por meio da qual Ihe pedia que tentasse publicar o seu romance $O$ lustre o mais rápido possível, Clarice Lispector nos fornece mostras dessa particularidade. Diante de uma eventual recusa por parte da editora, no caso a José Olympio, ela chegou a argumentar com o amigo:

Se eles fizerem qualquer tipo de oposição [...] então Tânia, minha irmã, se encarregará de arranjar algo mais modesto e possivelmente pago - mas rápido, rápido, porque me incomoda um trabalho parado; é como se me impedisse de ir adiante" (Lispector, Instituto Moreira Salles, 2004, p. 17).

Se a escrita propriamente dita é algo que morre ao ser lançado fora do corpo do escritor - ao ser dele ser separado -, ela, entretanto, ressurge vivificada na leitura que, por seu turno, implica o corpo do leitor.

A produção de determinados textos literários situa-se numa vertente que não os faz demandar interpretação; equivalem a uma produção ofertada ao Outro sem que, no entanto, a ele se Ihe peça ou espere compreensão. Eis, afinal, o caráter de não interpretabilidade do objeto de arte, uma vez que não corresponde a uma formação do inconsciente.

O relato dessa extimidade continua.

O que parece estar em jogo é a delimitação de uma borda, a circunvolução de um espaço onde $G$. H. pudesse se situar, reconhecendo-o como seu. Ela busca balizas que the possibilitem a apropriação desse lugar, um ponto por onde 
começar a arrumação, algum tipo de lastro que a guie na exploração da superfície daquele espaço. o quarto, metáfora do corpo, haveria de ser percorrido em toda a sua superfície. Superfície unilátera, tal como uma banda moebiana, na qual a borda interna do exterior se retorce na borda externa da intimidade.

A experiência da entrada de G. H. no quarto de Janair parece equivaler ao momento em que o infans entra no campo do Outro. Indiferenciado e alienado, nesse tempo o infans ainda está confundido com o corpo da mãe, absorto pela enxurrada de tudo o que Ihe advém através do furo do Outro em sua face de excesso. Nas palavras de G. H.:

É que apesar de já ter entrado no quarto, eu parecia ter entrado em nada. Mesmo dentro dele, eu continuava de algum modo do lado de fora. Como se ele não tivesse bastante profundidade para me caber e deixasse pedaços meus no corredor, na maior repulsão de que eu já fora vítima: eu não cabia. Ao mesmo tempo, olhando o baixo céu do teto caiado, eu me sentia sufocada de confinamento e restrição. E já sentia falta de minha casa. Forcei-me a me lembrar que também aquele quarto era posse minha, e dentro de minha casa: pois, sem sair desta, sem descer nem subir, eu havia caminhado para o quarto. A menos que tivesse havido um modo de cair num poço mesmo em sentido horizontal, como se houvessem entortado ligeiramente o edifício e eu, deslizando, tivesse sido despejada de portas a portas para aquela mais alta. Embaraçada ali dentro por uma teia de vazios, eu esquecia de novo o roteiro de arrumação que traçara, e não sabia ao certo por onde começar a arrumar. O quarto não tinha um ponto que se pudesse chamar de seu começo, nem um ponto que pudesse ser considerado o fim. Era de um igual que o tornava indelimitado (Lispector, [1964] 1998a, p. 45).

A sequência do relato continua no terreno da (in) diferenciação, no tempo necessário e vagaroso rumo à alteridade ao longo do qual G. H. tenta distinguir aquilo que é (ou não) seu.

\begin{abstract}
Aguardei que a estranheza passasse, que a saúde voltasse. Mas reconhecia, num esforço imemorial de memória, que já havia sentido essa estranheza: era a mesma que eu experimentava quando via fora de mim o meu próprio sangue, e eu o estranhava. Pois o sangue que eu via fora de mim, aquele sangue eu o estranhava com atração: ele era meu (Lispector, [1964] 1998a, p. 59).
\end{abstract}

\section{A ESCRITA - CRIAÇÃO:}

Alguns escritores, ao comentarem o ato de criação, testemunham uma experiência cuja temporalidade remonta ao instante no qual um fragmento desse vazio originário se inscreve no inconsciente. Trata-se de uma escrita que coloca em ato um instante que não tem por referência nem o passado, nem o futuro, pois tal ato simplesmente atualiza o tempo da origem, quando o real toca o ser através de um traço de escrita. Esse tempo equivale ao "agora", desdobramento do "instante-já", expressão forjada por Clarice Lispector, publicada em vários livros seus. Tal como a escritora indica na finalização de Água viva, "aquilo que ainda vai ser depois - é agora" (Lispector, [1973] 1998b, p. 87).

Ao se romper o sentido que até então revestia a sua rotina, aparentemente tranquila, G. H. vê o que só teria sentido a posteriori, na pungência de uma experiência que se passa na mais cabal intimidade com a falta de sentido. Indagando-se se aquele horror experimentado era amor, G. H. atravessa a matéria viva, passando pelo inferno, que vem do amor. Isso a leva ao que nela era irredutível, ao seu núcleo "neutro e inexpressivo" (Lispector, [1964] 1998a), à sua "identidade mais última" (Lispector, [1964] 1998a), que sempre estivera nos seus olhos no retrato. Ela testemunha uma trilha ao cabo da qual atinge o "murmúrio sem sentido humano", expressão "da sua identidade tocando na identidade das coisas" (Lispector, [1964] 1998a).

Ao chegar nesse ponto, G. H. vive uma "alegria inexpressiva, um prazer que não sabe que é prazer", "delicado demais para a sua grossa humanidade". Isto porque a Unheimlichkeit - a inquietante estranheza - presentifica o vazio de que se trata o lugar onde o ser falante se funda. Trata-se de um acontecimento de corpo, phático, que se dá no limite entre o real e o imaginário: a experiência da Unheimlichkeit corresponde a uma tomada do falante pelo real, na tentativa de dar nome ao inominável, e remonta ao tempo em que o infans, em seu anonimato, não acedera ainda à palavra.

\section{O ATO - ORIGEM:}

Admitir uma literatura que comporta os restos inassimiláveis do escritor é considerá-la produzida com a sua carne: se o corpo é o primeiro livro onde se inscrevem os traços que sustentam um falante, o livro é um pedaço do corpo que, ali, escreve(se). Disso resultará um autor e a construção de seu estilo. 


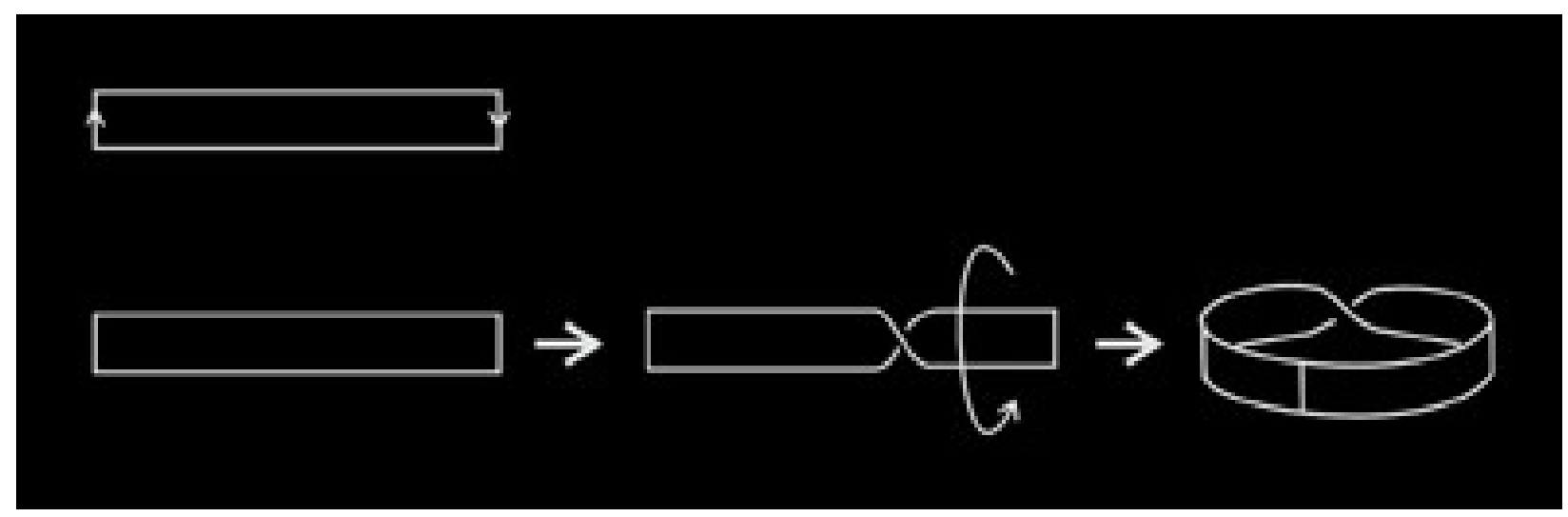

Figura 1 - In. GRANON-LAFONT, J. A topologia de Jacques Lacan. Rio de Janeiro: Jorge Zahar, 1990.

Alguns escritores mostram claramente tais pressupostos, dentre os quais Clarice Lispector. É nesse viés que, em Um sopro de vida (Lispector, [1977] 1999b), a escritora relacionou o conteúdo das linhas por ela traçadas aos restos d'alma de Ângela, a sua protagonista de então: “o que está escrito aqui, meu ou de Ângela, são restos de uma demolição de alma, são cortes laterais de uma realidade que se me foge continuamente. Esses fragmentos de livros querem dizer que eu trabalho em ruínas" (Lispector, [1977] 1999fb p. 20). Em Água viva, ela propôs "um livro feito aparentemente por destroços de livro" (Lispector, [1973] 1998b, p. 25), o que reitera o caráter de erosão de seus escritos, confirmado numa obra em que a história e o enredo se dissolvem a cada frase.

Um aspecto sobre esse Processo fica evidente ao longo da escrita do livro Água viva, publicado somente três anos após a sua primeira versão, composta inicialmente por 188 páginas. Até ele vir a público, em 1973, já reduzido a 97 laudas, tal livro ainda ganharia outras duas versões: Atrás do pensamento - Monólogo com a vida (escrita ao longo de 1971) e Objecto gritante (escrito em 1972). Água viva coloca em evidência um importante movimento quanto ao espaço no qual Clarice Lispector criava. Ao tomarmos como ponto de referência a relação de cada um de seus livros com as suas crônicas publicadas no Jornal do Brasil, veremos que o fazer ao qual esteve às voltas em Água viva a forçou a um trabalho que evidencia o caráter möebiano do texto - o texto enquanto corpo. Por quê? Porque, nesse momento, ela passou a colocar "fora do livro" o que antes tinha escrito para a sua coluna de crônicas; diferentemente da intertextualidade de quando escreveu Uma aprendizagem ou O livro dos prazeres, pois, em tal obra, essas crônicas foram inseridas "dentro do livro".

Vale recuperar que a banda de Möebius pode ser obtida a partir de uma meia torção - seja à direita ou à esquerda - realizada em uma fita retangular que, por sua vez, é operada sobre ela mesma antes que suas extremidades se unam. Isso faz que ela se assemelhe a um oito que se dobra sobre si mesmo, um oito interior. Trata-se de uma superfície unilátera, cuja orientação pode ser invertida. Isso porque verso e anverso são maleáveis, com a necessidade de um acontecimento temporal para que se diferencie o avesso do direito - o dentro e o fora - pois eles são separados pelo tempo que se leva para fazer uma volta suplementar, uma volta a mais em torno do furo que essa torção constitui (Granon-Lafont, 1985, p. 26).

O espaço destinado às cônicas de Clarice Lispector no Jornal do Brasil é subvertido. E, em Água viva, o elemento biográfico será reduzido à dimensão de um resto a ser descartado do texto como um efeito da conclusão da torção por nós suposta. Essa torção se dá nos moldes descritos acima.

Em entrevista concedida na época, a escritora revela a natureza de sua preocupação sobre o objecto gritante, título dado à versão inicial de Água viva, pois julgava que ela estava pessoal demais naquelas páginas, mais biográfica do que pretendia: "interrompi-o porque achei que não estava atingindo o que eu queria atingir. Não posso publicá-lo como está. Ou não publico ou 
resolvo trabalhar nele. Talvez daqui a uns meses eu trabalhe no Objecto gritante" (Lispector, apud Gotlib, 1995, p. 409).

Mais tarde, com a obra finalizada, ela declararia: "esse livrinho tinha 280 páginas, eu fui cortando cortando e torturando - durante três anos. Eu não sabia o que fazer mais. Eu estava desesperada. Tinha outro nome. Era tudo diferente [...] era Objecto gritante, mas não tem função mais. Eu prefiro Água viva, coisa que borbulha. Na fonte" (Lispector, apud Gotlib, 1995, p. 410).

Ao cabo desse processo, a protagonista de Água viva declara que, ao escrever, não queria se tornar autobiográfica e sim somente "bio" (Lispector, [1973] 1998b, p. 33). A personagem - uma artista plástica que, após uma separação amorosa, se arriscava pela primeira vez pelas veredas da escrita -, ao não querer ser autobiográfica, declara: "abro o jogo. Só não conto os fatos da minha vida: sou secreta por natureza" (Lispector, [1973] 1998b, p. 44). Acima de tudo, o que nesse livro Clarice endereça ao leitor é a letra enquanto objeto destacado do texto, dizendo-nos, via sua personagem, que "antes de mais nada te escrevo dura escritura. Quero como que poder pegar a palavra com a mão" (Lispector, [1973] 1998b, p. 12). Como se ao longo desse processo de revisão e corte se operasse a "travessia da autobiografia" (Branco, 2004, p. 209), evidenciando a torção que subverte a pessoalidade na obra da escritora. Se antes a sua história pessoal estava dentro do texto, ao final tal pessoalidade se reduz ao lastro simbólico que simplesmente movia a sua escrita.

Essa extimidade alcançada se confunde com uma impessoalidade, uma dessubjetivação, conduzindonos à noção lacaniana de sujeito como exsistência. Portanto, o elemento autobiográfico se transforma através de um ato-biográfico, como bem pondera Márcia Giovana Pedruzzi Reis (Reis, 2010). E se adotamos aqui o termo ato-biográfico é simplesmente para enfatizar a tensão que se dá "no giro que uma transmissão escrita pode operar quando se trata, no ato analítico (objeto da narrativa), de transmitir algo do isso, sujeito da enunciação, não atinente ao eu identitário que está em causa numa autobiografia" (Reis, 2010, p. 134). Ou, como escreve Cláudia Rego, ao comentar sobre a escrita da poeta Ana Cristina César (2005, p. 105): "o texto não é autobiográfico. É ato biográfico".
Ao longo das crônicas - e a partir do cruzamento delas com os livros de Clarice dessa mesma época - percebemos que ocorre uma ruptura na fronteira que separa o autor e o personagem, donde a posição do autor se confundir com a do narrador. Disso decorre a dificuldade em se precisar os limites entre ficção e realidade, que se dá em todo escrito cuja textualidade esbarra na literalidade (Poli, 2009).

Uma vez subvertida a pessoalidade do texto, encontramos, na versão final de Água viva (Lispector, [1973] 1998b), um escrito que evoca o que Lacan nomeou em sua lição sobre Lituraterra com o termo litura (Lacan, 2003): um texto levado ao esvaziamento do sentido, obtido através do ato de escrever, resultando numa produção em que o elemento biográfico se torna apenas vestígio.

\section{O NOME-INCÊNDIO:}

Analisando esse evento sob um prisma literário, apenas um ano após o incêndio que sofreu e apesar de sua "falta de jeito como cronista", Clarice assumia o tom autobiográfico em sua narrativa, finalmente assinando, com o seu próprio nome, uma coluna semanal em um jornal. Essas crônicas eram, em grande parte, fragmentos de textos livremente concebidos, por meio dos quais a escritora deixava o leitor a par de seu dia-adia doméstico, confidenciando-lhe, sobretudo, as vicissitudes do exercício de escrever. Essa nova maneira de conceber uma coluna semanal se revelaria amplamente diferente do caráter com que o público se deparava diante das crônicas de costumes da época. Por isso, podemos dizer que Clarice inventou uma nova maneira de fazer crônica: algo novo surgia ali.

A esse respeito, ela depôs, em sua crônica "Máquina escrevendo", publicada em 29 de maio de 1971 no Jornal do Brasil e depois compilada em seu livro $A$ descoberta do mundo:

\footnotetext{
Sinto que já cheguei quase à liberdade. A ponto de não precisar mais escrever. Se eu pudesse, deixava meu lugar nesta página em branco: cheio do maior silêncio. E cada um que olhasse o espaço em branco, o encheria com seus próprios desejos. Vamos falar a verdade: isto aqui não é crônica coisa nenhuma. Isto é apenas. Não entra em gênero. Gêneros não me interessam mais. Interessa-me o mistério. Antes havia uma diferença entre escrever e eu (ou não havia? Não sei). Agora mais não. Sou um ser. E deixo que você seja. Isso lhe assusta? Creio que sim. Mas vale a pena. Mesmo que doa. Dói só no começo (Lispector, [1971] 1999a, p. 347).
} 
Também em 21 de setembro de 1969, na crônica Fernando Pessoa me ajudando:

\begin{abstract}
Noto uma coisa extremamente desagradável. Estas coisas que ando escrevendo aqui não são, creio, propriamente crônicas, mas agora entendo os nossos melhores cronistas. Porque eles assinam, não conseguem escapar de se revelar. Até certo ponto nós os conhecemos intimamente. $E$ quanto a mim, isto me desagrada. Na literatura de livros permaneço anônima e discreta. Nesta coluna estou de algum modo me dando a conhecer. Perco minha intimidade secreta? Mas que fazer? É que escrevo ao correr da máquina e, quando vejo, revelei certa parte minha. Acho que se escrever sobre o problema da superprodução do café no Brasil terminarei sendo pessoal (Lispector, [1969] 1999a, p. 136-137).
\end{abstract}

Essas crônicas, que possuem o caráter de um diário - ou o de uma compilação de cartas -, são consideradas pela crítica literária como a autobiografia escrita pelo próprio punho da autora, "ainda que de modo inteiramente não planejado" (Manzo, 1997, p. 89), uma vez que a escritora não fazia ideia, àquela altura, de que essa mudança no caráter de suas crônicas "era uma questão de vida ou de morte" (Manzo, 1997, p. 94).

Segundo Lícia Manzo (1997), "ser pessoal" em sua literatura implicava o processo ao qual Clarice Lispector se referia como copiar a si própria, descobrindo os contornos de sua verdadeira voz, narrando diretamente aos seus leitores o que por ela era experimentado. Esse caráter será incorporado também aos seus livros, nos quais, a partir de então, cada vez mais os personagens cederão espaço à figura central de um narrador, que aos poucos se apresentará em primeira pessoa.

No que diz respeito a Clarice Lispector, o caráter autobiográfico de seus personagens femininos é um elemento francamente defendido pela crítica literária. Daí a escritora se fundir aos personagens, e os personagens a ela se sobreporem. Com a corroboração desse viés, em 09 de junho de 1974, Clarice Lispector se pronunciará numa entrevista concedida a Sérgio Augusto, Jaguar, Ziraldo e Ivan Lessa. Publicada em $O$ Pasquim, dentre as várias perguntas que Ihes foram feitas, ela responde:

- Clarice, até que ponto você se identifica com as suas personagens? Até que ponto você é a Joana de Perto do coração selvagem, uma pessoa lúcida que não se encontra na realidade? - Bem, Flaubert disse uma vez: "Madame Bovary sou eu" (Lispector apud Manzo, 1997, p. 3).

\section{O AMOR - INTERTEXTUALIDADE:}

Ao avançarmos no cotejamento das crônicas publicadas por Clarice Lispector no Jornal do Brasil entre 1967 e 1973, deparamo-nos com uma característica bastante acentuada em seu processo de criação: a intertextualidade. Essa característica, por sua vez, desdobra-se numa outra: a repetição. É possível reencontrarmos trechos de suas crônicas em muitos de seus livros, ou até mesmo crônicas inteiras antes redigidas para o Jornal do Brasil.

Publicada em 18 de maio de 1968, a crônica intitulada "Enquanto vocês dormem" é um bom exemplo disso, uma vez que reaparecerá inteira no livro Uma aprendizagem ou O livro dos prazeres, publicado no início de 1970. A única mudança empreendida na segunda publicação se refere ao nome da protagonista da história, que, no livro, passa a se chamar Lóri, epíteto de Loreley. Personagem, aliás, que no romance corresponde a um "eu", pois sobre ela o narrador - em terceira pessoa - dirá "que queria que ela, ao lhe perguntarem seu nome, não respondesse "Lóri", mas que pudesse responder "meu nome é eu", pois "teu nome, dissera ele, é um eu" (Lispector, 1998d, p. 13).

O intercâmbio entre esses dois registros de escrita - as crônicas do Jornal do Brasil e livros como Uma aprendizagem ou Livro dos prazeres - nos faz pensar no caráter indissociável deles. Isso nos leva também a supor que o conjunto da obra de Clarice Lispector fora concebido ao modo de uma trança. Uma trança entre essas vozes femininas, sobrepujadas entre si. Entre a primeira e a terceira pessoas, a narrativa é sustentada ora por um narrador, ora por um personagem, mas sempre por essa voz emitida a partir de uma determinada posição enunciativa do autor, paradigma da máxima "Eu é um outro", já sustentada por Rimbaud3.

Outro exemplo de intertextualidade fica patente no entrecruzamento que estabeleceremos a seguir. Em crônica publicada no Jornal do Brasil em 26 de outubro de 1968, chamada "A bravata", é descrito o pavor de uma misteriosa "Z. M." diante de uma festa a que fora convidada. Tímida, essa mulher precisaria vestir uma "máscara de coragem" em seu rosto desnudo, para, então, enfrentar o evento social. Dele ela volta horas depois com as seguintes conclusões: 
Z. M. sentia que a vida Ihe fugia por entre os dedos. Na sua humildade esquecia que ela mesma era fonte de vida e de criação. Então saía pouco, não aceitava convites. Não era mulher de perceber quando um homem estava interessado nela a menos que ele 0 dissesse - então se surpreendia e aceitava [...] vestiu um vestido mais ou menos novo, mas a coragem não vinha. Então - só entendeu depois - pintou demais os olhos e demais a boca até que seu rosto parecia uma máscara: ela estava pondo sobre si mesma alguém outro: esse alguém era fantasticamente desinibido, era vaidoso, tinha orgulho de si mesmo. Esse alguém era exatamente o que ela não era. Mas na hora de sair de casa, fraquejou: não estaria exigindo demais de si mesma? Toda vestida, com uma máscara de pintura no rosto, - ah, persona, como não te usar e enfim ser! -, sem coragem, sentou-se na poltrona de sua sala tão conhecida e seu coração pedia para ela não ir. Parecia que previa que ia se machucar muito e ela não era masoquista. Enfim apagou o cigarro-de-coragem, levantou-se e foi.

Pareceu-Ihe que as torturas de uma pessoa tímida jamais foram completamente descritas. No táxi que rolava ela morria um pouco.

E ei-la de repente diante de um salão enorme com talvez muitas pessoas, mas pareciam poucas dentro do descomunal espaço onde se processava como um ritual moderno o coquetel [...] Era inútil esconder: a verdade é que não sabia viver. Em casa estava agasalhante, ela se olhou ao espelho quando lavava as mãos e viu a persona afivelada no seu rosto: a persona tinha um sorriso parado de palhaço. Então lavou o rosto e com alívio estava de novo de alma nua. Tomou então uma pílula para dormir. Antes que chegasse o sono, ficou alerta e se prometeu que nunca mais se arriscaria sem proteção. A pílula de dormir começava a apaziguála. E a noite incomensurável dos sonhos começou (Lispector, [1968] 1999a, p. 146-148).

Essa mesma experiência será transferida a Lóri no capítulo em que a protagonista do romance vê-se obrigada a ir à uma recepção no Museu de Arte Moderna. Tomada por uma forte apreensão enquanto se arrumava para a festa, Lóri chegará às mesmas conclusões de "Z. M.". Eis o trecho, praticamente idêntico, tal como ele ressurge em Uma aprendizagem:

Vestiu um vestido mais ou menos novo, pronta que queria estar para encontrar algum homem, mas a coragem não vinha. Então, sem entender o que fazia - só o entendeu depois - pintou demais os olhos e demais a boca até que seu rosto branco de pó parecia uma máscara: ela estava pondo sobre si mesma alguém outro: esse alguém era fantasticamente desinibido, era vaidoso, tinha orgulho de si mesmo. Esse alguém era exatamente o que ela não era.

$\mathrm{Na}$ hora de sair de casa, fraquejou: não estaria exigindo demais de si mesma? Não seria uma bravata ir sozinha? Toda pronta, com uma máscara de pintura no rosto - ah "persona", como não te usar e ser! - sem coragem, sentou-se na poltrona de sua sala tão conhecida e seu coração pedia para ela não ir. Parecia prever que ia se machucar muito e ela não era masoquista. Enfim apagou o cigarroda-coragem, levantou-se e foi.

Pareceu-Ihe que as torturas de uma pessoa tímida jamais tinham sido completamente descritas - no táxi que rolava ela morria um pouco.

E de repente ei-la diante de um salão descomunal de grande com muitas pessoas, talvez, mas pareciam poucas dentro do espaço enorme onde como um ritual se processava o coquetel [...] entrou em casa como uma foragida do mundo. Era inútil esconder: a verdade é que não sabia viver. Em casa estava bom, ela se olhou ao espelho enquanto lavava as mãos e viu a "persona" afivelada no seu rosto. Parecia um macaco enfeitado. Seus olhos, sob a grossa pintura, estavam miúdos e neutros, como se no homem ainda não se tivesse manifestado a Inteligência. Então lavou-o, e com alívio estava de novo de alma nua. Tomou então uma pílula para dormir e esquecer o fracasso de sua bravata. Antes que chegasse o sono, ficou alerta e se prometeu que nunca mais se arriscaria sem proteção.

A pílula de fazer dormir começara a apaziguá-la. E a noite incomensurável dos sonhos começou, vasta, em levitação (Lispector, 1998d, p. 83-86).

Clarice também retomará tais nuances em sua crônica "Persona", publicada em 02 de março de 1968. Surpreendentemente, reconheceremos trechos dessa crônica também em seu livro Uma aprendizagem ou O livro dos prazeres, exatamente na sequência dos fragmentos anteriormente referidos quanto à crônica "A bravata" - igualmente localizáveis naquele livro. Entre as personas aventadas em "Z. M." e Lóri, finalmente Clarice esclarece:

Vou falar da palavra pessoa, que persona lembra. Acho que aprendi o que vou falar com meu pai. Quando elogiavam demais alguém, ele resumia sóbrio e calmo: é, ele é uma pessoa. Até hoje digo, como se fosse o máximo que se pode dizer de alguém que venceu numa luta, e digo com o coração orgulhoso de pertencer à humanidade: ele, ele é um homem. Obrigada por ter desde cedo me ensinado a distinguir entre os que realmente nascem, vivem e morrem, daqueles que, como gente, não são pessoas.

Persona. Tenho pouca memória, por isso já não sei se era no teatro grego que os atores, antes de entrar em cena, pregavam ao rosto uma máscara que representava pela expressão o que o papel de cada um deles iria exprimir [...] Mesmo sem ser atriz nem ter pertencido ao teatro grego - uso uma máscara. Aquela mesma que nos partos de 
adolescência se escolhe para não se ficar desnudo para o resto da luta. Não, não é que se faça mal em deixar o próprio rosto exposto à sensibilidade. Mas é que esse rosto que estava nu poderia, ao ferir-se, fechar-se sozinho em súbita máscara involuntária e terrível. É, pois, menos perigoso escolher sozinho ser uma pessoa. Escolher a própria máscara é o primeiro gesto voluntário humano. E solitário. Mas quando enfim se afivela a máscara daquilo que se escolheu para representar-se no mundo, o corpo ganha uma nova firmeza, a cabeça ergue-se altiva como a de quem superou um obstáculo. A pessoa é. Se bem que pode acontecer uma coisa que me humilha contar.

É que depois de anos de verdadeiro sucesso com a máscara, de repente - ah, menos que de repente, por causa de um olhar passageiro ou uma palavra ouvida - de repente a máscara de guerra de vida cresta-se no rosto como lama seca, e os pedaços irregulares caem como um ruído oco no chão. Eis o rosto agora nu, maduro, sensível quando já não era mais para ser. E ele chora em silêncio para não morrer. Pois nessa certeza sou implacável: este ser morrerá. A menos que renasça até que dele se possa dizer "esta é uma pessoa". Como uma pessoa, teve que passar pelo caminho de Cristo (Lispector, [1968] 1999a, p. 80) ${ }^{4}$.

Ao preço de uma repetição, percebe-se que, nessa época, Clarice Lispector vacila entre escrever "ela" ou "eu", fato que talvez a tenha levado a interferir até mesmo em textos seus já publicados. $\mathrm{E}$, notemos bem, a intertextualidade era tamanha que algumas de suas crônicas foram publicadas sem título, constando no lugar deste apenas a designação "Trecho". Noutras, o vocábulo "trecho" compareceria como uma espécie de subtítulo complementar. Esses "trechos", todavia, reapareceriam na trama do livro Uma aprendizagem ou o livro dos prazeres, o que nos faz supor que eles teriam sido escritos inicialmente para esse livro, embora, no jornal, a narradora quase sempre se colocasse em primeira pessoa ${ }^{5}$.

A vasta correspondência que recebia de seus leitores - das mais variadas idades e realidades - apontava a um denominador comum: predominava, por parte de seu público, o desejo de que Clarice se mantivesse o mais pessoal possível em suas crônicas, prosseguindo nessa vertente em que ela própria seria o personagem principal de sua narrativa.

Noquediz respeito aessas crônicas, aopercorrermos o sumário do livro que as compila - $A$ descoberta do mundo, organizado por seu filho Paulo em 1984 - constatamos que os significantes "escrita", "escrever", "escrevendo" e "amor" comparecem de maneira privilegiada, em detrimento do significante "literatura", quase nunca mencionado (Branco, 2004, p. 201). De modo semelhante a James Joyce, cujo exercício com as letras derivou da tentativa de forjar o "significante do inefável que recobrisse um sentido absoluto" (Branco, 2004, p. 193), Clarice Lispector, ao que supomos, tentava designar essa palavra ora por meio do significante "escrita", ora pelo termo "amor" (Branco, 2004). É como se Lispector estivesse em busca de uma palavra suficientemente capaz de nomear o indizível, cuja potência poética a dotaria do caráter de dizer sobre o inominável. Uma palavra - ou seja, um significante - cujo estatuto seria intervir no real, nomeando-o, circunscrevendo o limite entre o que é e não é possível exprimir.

\section{QUASE PERTO DO FIM:}

A coluna de crônicas assinada por Clarice Lispector parece ter the possibilitado um espaço que consideramos imprescindível no que diz respeito à nova maneira da escritora se relacionar com o seu leitor e, consequentemente, com a sua própria obra. E se a escrita cumpre funções diferentes, para diferentes sujeitos, em diferentes momentos, Clarice Lispector parece ter encontrado, através do seu processo de escrita, o próprio manejo implicado no refazer de seu corpo, em que vida e obra, indissociáveis, permearam a produção de um estilo, uma vez subvertida a pessoalidade do texto...

... um texto progressivamente levado ao esvaziamento do sentido, resultando numa produção em que o elemento biográfico se torna apenas vestígio, quase silêncio.

\section{NOTAS}

1. A palavra Poubelle, no idioma francês, designa "lata de lixo". Além de se referir dessa forma à obra de James Joyce, especialmente em Lituraterra, Lacan também discorre a esse respeito no Seminário 13 (1965-1966), O objeto da psicanálise, na lição em que trata da caligrafia japonesa, datada de 05 de dezembro de 1965.

2. Trecho de uma entrevista de Clarice concedida a Affonso Romano de Sant'Anna e Marina Colasanti em 20/10/1976, publicada em nota prévia no livro Para não esquecer (Lispector, 1999c). 
3. Numa de suas cartas endereçadas a Paul Démeny, Rimbaud deixa clara a sua discordância em relação ao "penso, logo sou" cartesiano, propondo, em contrapartida, a máxima "Je est un autre / Eu é um outro". Para ele, a fórmula "Eu penso" é um grande engodo, pois considera que, ao invés disso, o que se passa na verdade é da ordem de um "Pensam-me". Ou seja, o Eu diz Rimbaud antes mesmo que Freud o faça - é pensado por um outro.

4. Os trechos dessa crônica podem ser encontrados entre as páginas 85 e 86 do livro Uma aprendizagem ou O livro dos prazeres (1998d), amalgamados aos trechos também localizados na crônica "A bravata". A única diferença é que, no livro, é Lóri quem discorre sobre o significante Persona.

5. A esse respeito, vale mencionar as crônicas publicadas no Jornal do Brasil no dia 04 de maio de 1968, intituladas "A alegria mansa - trecho" e "A volta ao natural - trecho". Além destas, citemos também a crônica "Ritual - trecho", publicada em 27 de julho de 1968. Essas crônicas podem ser encontradas no livro $A$ descoberta do mundo, respectivamente nas páginas 98,99 e 119 de sua edição de 1999. A diferença entre esses "trechos", quando publicados no livro Uma aprendizagem ou livro dos prazeres, é que nas crônicas o nome "Lóri" é simplesmente excluído e, com isso, os "trechos" do jornal são colocados em referência a um misterioso "ela", personagem ainda sem nome.

\section{REFERÊNCIAS}

BERNARDES, Ângela. Um amor reinventado: a arte do poeta e o discurso do analista. In: MELLO, Márcia.; JORGE, Marco Antônio Coutinho. (Org.). Psicanálise e Arte: saber fazer com o Real. Rio de Janeiro: Cia de Freud, 2009.

BORELLI, Olga. Clarice Lispector: esboço para um possível retrato. Rio de Janeiro: Nova Fronteira, 1981.

BRANCO, Lúcia Castello.; BRANDÃO, Ruth Silviano. A mulher escrita. Rio de Janeiro: Lamparina Editora, 2004.

BRANDÃO CARREIRA, Luciana. Os tempos da escrita na Obra de Clarice Lispector - no litoral entre a literatura e a psicanálise. Rio de Janeiro: Cia de Freud, 2014.

BRANDÃO CARREIRA, Luciana. Clarice Lispector e a passagem de uma escrita a outra escrita. In: COSTA, Ana.; RINALDI, Dóris. (Org.). A escrita como experiência de passagem. 1ed. Rio de Janeiro: Cia de Freud, 2012, v. 1, p. 37-49.

BRANDÃO CARREIRA, Luciana. O tempo da escrita no corpo estruturado como linguagem. In: MANSO, R.; ELIA, L. (Org.). Estrutura e psicanálise. 1ed. Rio de Janeiro: Cia de Freud, 2012 , v. 1, p. 347-360.

CALDAS, Heloísa. Da voz à escrita: clínica psicanalítica e literatura. Rio de Janeiro: Contra Capa Livraria, 2007.

GOTLIB, Nádia. Clarice: uma vida que se conta. São Paulo: Ática, 1995.

GRANON-LAFONT, Jeanne. A topologia de Jacques Lacan. Rio de Janeiro: Jorge Zahar, 1990.

INSTITUTO MOREIRA SALLES. Cadernos de literatura brasileira: Clarice Lispector. Vols. 17 e 18. São Paulo: Instituto Moreira Salles, 2004.

LISPECTOR, Clarice. A paixão segundo G.H. Rio de Janeiro: Rocco, 1998a.

LISPECTOR, Clarice. Água viva: ficção. Rio de Janeiro: Rocco, 1998b.

LISPECTOR, Clarice. A hora da estrela. Rio de Janeiro: Rocco, 1998c.

LISPECTOR, Clarice. Uma aprendizagem ou 0 livro dos prazeres. Rio de Janeiro: Rocco, 1998d.

LISPECTOR, Clarice. A descoberta do mundo. Rio de Janeiro: Rocco, 1999a.

LISPECTOR, Clarice. Um sopro de vida. Rio de Janeiro: Rocco, 1999b.

LISPECTOR, Clarice. Para não esquecer. Rio de Janeiro: Rocco, 1999c.

LACAN, Jacques. O Seminário, livro 11: Os quatro conceitos fundamentais da psicanálise (1964). Rio de Janeiro: Jorge Zahar, 1998.

LACAN, Jacques. O Seminário, livro 13: L'objet de la psychanalise (1965-1966). Publicação não comercial da Associação Freudiana Internacional. Inédito. 
LACAN, Jacques. O Seminário, livro 19: ...Ou pior (1971-1972). Inédito.

LACAN, Jacques. o Seminário, livro 21: Les nondupes errent (1973-1974). Inédito.

LACAN, Jacques. Lituraterra (1971). In:

Outros escritos. Rio de Janeiro: Jorge Zahar, 2003, p.15-25.

LACAN, Jacques. O Seminário, livro 18: De um discurso que não fosse do semblante (1971). Rio de Janeiro: Jorge Zahar, 2009.

MANZO, Lícia. Era uma vez: Eu - a não-ficção na obra de Clarice Lispector. Curitiba: Secretaria de Estado da Cultura: The Document CompanyXerox do Brasil, 1997.

POLI, Maria Cristina. Uma carta perdida. Revista da Associação Psicanalítica de Porto Alegre, v.1, p.20-27, 2009.

REIS, Márcia. De uma escrita com função de testemunho: abordagem psicanalítica da transmissão da experiência. Dissertação (Mestrado em Psicologia Social e Institucional) - Universidade Federal do Rio Grande do Sul, Instituto de Psicologia. Porto Alegre, 2010.

\section{SOBRE A AUTORA:}

Luciana Brandão Carreira é escritora, psicanalista e psiquiatra. Doutora em Psicanálise pela UERJ / Université Paris XIII, França, com pós-doutorado em Estudos Literários pelo Instituto de Estudos de Literatura e Tradição (IELT) da Universidade Nova de Lisboa, Portugal. É professora adjunta da Universidade do Estado do Pará (UEPA), onde coordena o Laboratório de Artes e Humanidades Médicas da Uepa. No Centro de Ensino Superior do Pará (Cesupa), trabalha como preceptora do Ambulatório de Saúde Mental, onde também compõe o corpo docente do Mestrado em Ensino em Saúde - Educação Médica. Em suas pesquisas, articula os fundamentos de Freud e Lacan ao campo das artes, em especial às artes literárias. É autora dos livros Entre (Verve, 2014), Os tempos da escrita na obra de Clarice Lispector - no litoral entre a literatura e a psicanálise (Cia de Freud, 2014), A letra da Água (Paka-tatu, 2017), Quinze vezes o cravo - A tradução como Ato (Lumme, 2018) e Porta-Voz (livro premiado na categoria Poesia pelo edital Prêmios literários 2018 da Fundação Cultural do Pará - FCP), dentre inúmeros artigos publicados em várias revistas. Foi contemplada em 2016 com o prêmio Carlos Drummond de Andrade de Literatura, concedido pelo Sesc do Distrito Federal, na categoria Poesia. 


\title{
POR UMA CURADORIA OPERÁRIA
}

\section{Ana Luisa Lima \\ MAMAM}

\author{
"Ser revolucionário é a profissão natural de um intelectual." \\ Mario Pedrosa em entrevista ao Pasquim
}

No último 28 de outubro, confirmou-se uma tragédia no país. A farsa e a violência foram estratégias muito bem conduzidas para eleger um político, irrelevante nos seus 30 anos de mandatos legislativos, de características fascistas como o $38^{\circ}$. presidente do Brasil. Mais de 57 milhões de pessoas legitimaram a aniquilação da possibilidade de vida plural tornando afrodescendentes, povos originários, a população LGBTI e feministas alvos de tortura e de morte, tanto quanto reiteraram o Partido dos Trabalhadores como um mal a ser extirpado.

É tanto possível, quanto necessário, manifestar muitas críticas contundentes ao PT. Sobretudo, por sua atuação para viabilizar a Usina Hidrelétrica de Belo Monte e, com isso, promover um dos maiores ecocídios e genocídios na região do Xingu que se tem notícia. No entanto, é impossível deixar de reconhecer sua política assertiva em diminuir a miséria do país, dando a oportunidade real de milhões de pessoas muito pobres de ter acesso à alimentação e à universidade pública de qualidade. O Brasil é um jovem' país com um pouco mais de 500 anos. A sua história foi marcada pelo colonialismo imperial, posteriormente, convertido num servilismo político e econômico-financeiro. O PT, por meio do ex-presidente Luiz Inácio Lula da Silva, mesmo com todas as suas contradições, trouxe uma chance de emancipação. A existência do BRICS, por exemplo, foi um protagonismo imperdoável aos velhos países imperialistas.

A retomada do discurso fascista na comunidade global é uma agenda perigosa e tem se demonstrado muito eficiente em reconduzir populações inteiras ao pensamento estreito, violento e preconceituoso. Qualquer negação aos modos plurais de ser e estar no mundo deve servir de alerta a todas e todos que acreditam na liberdade, na igualdade e na fraternidade (um lema francês que merece respeito). Para nós, agentes das artes, esse alerta deve ser nossa maior pauta. A arte não pode servir à opressão, muito pelo contrário, há de ser o escudo mais vigoroso na proteção das populações e grupos de pessoas mais vulneráveis.

Com a demonização mundial do comunismo", uma luta real e constante, tornou-se invisível: a do proletariado. Não são ingênuos (tampouco ufanista, os meus desejos revolucionários), o trabalho árduo e a convergência de pensamentos que, desde o início de minha trajetória, me dediquei a observar, entender e questionar os sintomas do modo capitalista de ser e estar no mundo entranhados no campo das artes.

Então, antes desenvolver alguns pensamentos sobre curadoria, algumas situações precisam ver observadas. São considerações que há muito tenho insistido em retomar, porque o exercício de pensar não pode ser sem fundamento. $E$ as tomadas de posições necessárias de acordo com as circunstâncias pedem.

\section{DO CONTEXTO}

Algo que tem se demonstrado cada vez mais claro é que o marxismo ortodoxo falhou em prever o fim do capitalismo e quando vislumbrou uma sociedade socialista não soube reconhecer a potência da individualidade nessa construção. Há nada de tardio nesse sistema que parece tomar novo fôlego depois de cada crise. Em sua forma atual, sinais fracos das antigas ideologias, nos tornamos simplificados como elementos de dois conjuntos: com dinheiro e sem dinheiro, sem garantia alguma de permanência em um e outro. Assim, um esmagamento sem precedentes do 
sujeito/subjetividade nos tem feito perder até os mais simples parâmetros de pertencimento. Quase já não há conjunções simbólicas que nos contornem: primeiro como coletividade; segundo, como indivíduos. É sem pudor que o neoliberalismo nos fez vulneráveis ao humor da economia. Seja em nome da governabilidade, seja nas decisões aparentemente banais de nosso diariamente: há nada que fuja da baliza econômica. Massa informe, homogeneizada, ainda que seja por meio dos discursos de singularidade, somos parte da grande engrenagem de manutenção do sistema no qual cada desejo mais íntimo é transformado em commodity - vide o Facebook.

Os sinais de fracasso que fizeram celebrar a morte do autor, o fim da história, e das utopias, têm nos feito caminhar para o auge de uma era que passei a chamar de "Finus lato sensu", porque o fim de todos os parâmetros nos parece ser uma finalidade em si mesmo e, esse estado de um "sem finalidade", nos coloca numa perspectiva de "looping", de um "sem fim". Eram os sintomas de fim de uma situação que possibilitava a demarcação de tempo como também a possibilidade de amanhecer novas tomadas de posição. Ao contrário disso, esse modo contemporâneo de percepção, de ser e estar no mundo, parece mesmo se afirmar como existência condensada de espaço-tempo numa aceleração exacerbada criando uma temporalidade sem esquinas.

O campo da arte é espelho dessa condição. E é com arrogância que as artes visuais vociferam ser a primazia da arte, e, quando o discurso the interessa, ser um passo além da cultura. $O$ fato é que ninguém está imune. Nenhum de seus agentes (independentes ou institucionais), está fora de viver sob a recorrente necessidade de adaptação pelos manejos retóricos ao sabor caprichoso do mercado. Nos modos do capital já não há um dentro e fora. 0 que é preciso perceber é que há muito se colocaram em marcha ações que sutilmente tornaram privadas as experiências coletivas. Em nome da profissionalização do campo, já não há, em grande escala, qualquer proposição artística em que o coletivo venha antes do privado. Sintomas disso são, cada vez mais legitimadas, as feiras de arte e exposições espetaculares em que o consumo toma o lugar da fruição. O consumo não é outra coisa do que a volta de uma percepção meramente retiniana"I da obra. Como haver produção de diálogos, criação de subjetividades, sem essa possibilidade da experiência estética pelo corpo? Não é a possibilidade dialógica, criadora e criativa, que há nas experiências estéticas que fazem a arte ser eventualmente imaginário coletivo? Respondidas essas perguntas talvez possamos nos dar conta desse perigoso processo que tem feito a arte perder seu valor simbólico para ganhar cada vez mais apenas valor de mercado.

\section{DAS CIRCUNSTÂNCIAS}

Outra pergunta que me ocorre, corolário das anteriores, é: as questões da curadoria são apenas sintomas do modo capitalista em que a arte se deixou engolfar? Notadamente, em nome da profissionalização do campo, o fenômeno da produção artística deixou de ser algo que diz respeito apenas ao artista em seu ateliê. Ao que parece, a produção artística não mais existe sem a mediação institucional-mercadológica que cumpre a dupla função de nomear (legitimar) e demandar. De modo que, dentro dessa lógica, a figura do/a curador/a é menos um agente, mais um/a articulador/a nessa grande engrenagem.

A estrutura pela qual a arte se deixou sucumbir é tão esquizofrênica que a obra em que a priorimovia e era ela mesma produção de conhecimento, nos moldes atuais, tornou-se apenas alvo do manejo retórico laudatório com a finalidade última de especulação do seu valor de mercado. Em outras palavras, o/a artista era o/a produtor/a simbólico que gerava, em torno de si, a produção de conhecimento, e não o contrário. A curadoria, a crítica de arte, e os públicos, diante da produção artística, flexionavam as desinências de acordo com os radicais produzidos pelos/as artistas. De modo que o vocabulário estético era também político, porque se tratava de uma construção dialética dos/as agentes culturais (artista, crítico/a, público, curador/a, etc). Nas condições atuais, o mercado especializou-se em criar demandas de produções artísticas adjetivadas (arte digital, arte política, arte performática, arte vida etc), de tal maneira que as curadorias/editais culturais passaram a impor o vocabulário estético a ser usado pelo/a artista.

Ao que os fatos indicam, criou-se uma lacuna de assuntos que movam debates relevantes sobre arte. O que há é uma produção exacerbada de textos curatoriais que são tagarelices, com pretensões 
filosóficas, em que os trabalhos são apresentados como meras ilustrações de verbetes. Há muito não se vê circular qualquer tipo de debate gerado pela arte que seja de relevância coletiva. Muito pelo contrário, o que se tem visto é o foco voltado para curadores/as cada vez mais tratados/as como celebridades. Em suma, o que se vê nos jornais e revistas internacionais, é um excesso de listas de curadores/as legitimados/as por um mercado que estimula quantidade no lugar da qualidade dos projetos realizados por esses/as.

Se as atuais produções curatoriais são apenas sintomas do modo de ser e estar no mundo ditados pelo capital, outra coisa é certa: o caminho que a arte segue também é um sintoma desse modo de fazer curadoria. 0 que se pode dizer disso é que a produção artística encurralada nesse jogo de demanda e legitimação tem se deixado repetir em procedimentos e visualidades. Tais repetições dão lugar a um Formalismo Vulgariv em que se torna irrelevante querer flexionar as desinências dos mesmos radicais, não?

\section{O QUE É CURADORIA?}

Talvez, haja uma desvantagem em abordar o assunto sob a perspectiva do que éuma curadoria. Porque no discurso da contemporaneidade, em que 'todas as formas' são possíveis, o fenômeno existe como prática (re)conhecível, inclusive em campos que já ultrapassaram os domínios das artes visuais, ainda que não se possa definir, exatamente, os termos dessa prática. No que diz respeito ao debate, acredito que melhor pergunta fazemos no 'para quê', 'para quem'? Explico: embora exista um esforço em se diluir, criar falsas simetrias, e até mesmo anular, o parâmetro de direita e esquerda na vida política, esse é ainda o único em que consigo encontrar respiro e pulsação para os modos de ser e estar no mundo. E para deixar claro do que estou falando, tomo a liberdade de parafrasear Deleuze (em depoimento que dá numa série de entrevistas conhecida como "O abecedário de Gilles Deleuze"). Ora, ser de esquerda é vislumbrar o horizonte, antes de a si mesmo. É um pensar-agir consciente de que o coletivo vem antes do individual, de que o público vem antes do privado. E isso não passa por uma questão moral, ou uma jornada espiritual altruísta, é uma questão de percepção. Dito isso, para mim, é inevitável que meus questionamentos acerca da curadoria recaiam mais sobre 'para quem', menos no 'como'.

No que se refere à arte, não consigo vislumbrar outro modo de percebê-la senão como política. Penso que já não seja mais necessário dizer que uma arte que se quer política não tem a ver meramente com os conteúdos sociais ou ainda engajamento partidário. Muito pelo contrário, me parece que cada vez mais o político na arte diz respeito à reinvenção dialética dos vocabulários, dos modos de perceber, da instauração de espaços públicos. Cabe dizer ainda que os espaços públicos não são apenas aqueles em que, em tese, qualquer pessoa pode ir-e-vir, mas aqueles espaços em que as pessoas se encontram em plena faculdade de exercer seu direito de falar que é o exercício político por natureza. Como alerta Hannah Arendt "isonomia não significa que todos são iguais perante a lei nem que a lei seja igual para todos, mas sim que todos têm o mesmo direito à atividade política; e essa atividade na polis era de preferência uma atividade da conversa mútua"v.

Então, uma resposta possível à pergunta do 'para quê'/para 'quem' se presta uma curadoria seria isso: a instauração de um espaço público. Lugar em que o diálogo se estabelece sem dirigismos, falsas promessas de interatividade sobre o pretexto de poéticas "relacionais". Ora, a mera interatividade não é em si um 'espaço' construído para o diálogo. Entende-se por obras interativas aquelas em que o/a fruidor/a precisa agir-com para que a obra aconteça. O problema é que esse agir-com, recebido com tanto entusiasmo em nosso meio, pode mascarar a inabilidade de algumas obras de se deixar construir, efetivamente, pela ação, bem como impede que o/a fruidor/a se construa a partir da experiência. Por exemplo, as obras que nos incitam unicamente a reagir aos estímulos propostos, e que os resultados já são previstos. Logo, não podemos falar em construção: nem do ponto de vista da obra, nem do/a fruidor/a que passa a ser mero aparato estético desta. Assim, falo de um lugar em que a experiência estética por si mesma é condutora de diálogos com todo e qualquer público. Nesse sentido, cada vez mais me assusta uma naturalização da privatização da experiência coletiva, como se a mera organização de qualquer exposição já fosse por si mesma uma promessa de experiência que leva as construções de subjetividade. Sabemos que não. 
Outro problema grave que tem sido tratado como natural sob a luz do mercado, é a precarização do trabalho tanto do/a artista, quanto do/a curador/a. Ativados por demandas excessivas de exposições, em sua maioria de interesse privado, em nome da necessidade de visibilidade, e subsistência, tanto o/a artista quanto o/a curador/a acabam se submetendo a exercerem multi-funções com remunerações irrisórias, ou, nenhuma. Então, a ideia de que temos atuado dentro de um programa de curadoria operária é fato. Infelizmente, menos em nome de um pensamento ideológico de busca por mudanças efetivas na vida política e civil, mais por nos deixarmos reproduzir essa condição 'industrial' no campo das artes sem o menor pudor.

\section{UM OLHAR POSSÍVEL}

Há, no entanto, que se forjar, pelo menos, outros modos de caminhada nem que seja para implodir, desconstruir, o que parece ser um caminho sem volta. E eu não vejo maneira de fazê-lo senão seguir perguntando, questionando, propondo outras formas de. Já perceberam quanto Políticae Sujeito são temas constantes na arte contemporânea? Tais verbetes, contudo, são invocados nos eventos de artes, menos para ser discutidos, questionados, ampliados, e mais para servir de justificativa enquanto "qualidade filosófica" de tais eventos. É preciso uma nova subjetividade que acenda a discussão da necessidade de (re) pensar os valores da obra de arte enquanto construção de um imaginário simbólico coletivo. Um modo de assegurar a preponderância da experiência estética em si mesma, no lugar de (re) naturalizar a aura do caráter objetual da obra. O conceito de nova subjetividade ainda é algo em construção cuja a base se encontra no legado da Nova Objetividade, que segundo Hélio Oiticica se estrutura a partir das seguintes ideias:

\footnotetext{
“1 - vontade construtiva geral;

2 - tendência para o objeto ao ser negado e superado o quadro de cavalete;
}

3 - participação do espectador (corporal, táctil, visual, semântica, etc.);

4 - abordagem e tomada de posição em relação a problemas políticos, sociais e éticos;

5 - tendência para proposições coletivas e conseqüente abolição dos "ismos" característicos da primeira metade do século na arte de hoje (tendência esta que pode ser englobada no conceito de "arte-pós-moderna" de Mário Pedrosa);

6 - ressurgimento e novas formulações do conceito de antiarte."

Penso que embora Oiticica tenha conseguido clarificar bem os termos da produção artística daquele momento como "um estado típico de arte brasileira", ainda assim, recorrentemente hoje quando se voltam para aquele momento histórico da arte o fazem cada vez mais sob termos formalistas e menos políticos. Como se o contexto histórico daquela produção fosse mero substrato da obra e não parte integrante de sua própria constituição. Acredito que algumas manifestações artísticas atuais estão profundamente entranhadas do legado deixado pela Nova Objetividade, ainda que o ponto de partida não seja mais um desejo de objetividade, mas de subjetividade.

É pensando sobre isso que proponho um olhar sobre a atual arte contemporânea brasileira. Ao contrário do que se pode imaginar não existe de fato uma ruptura entre aquele momento histórico e o atual. Apenas os modos de criação parecem tomar sentidos inversos do que aqueles, ainda que permaneçam, no fim, numa mesma direção. Ora, na Nova Objetividade era o substrato social, coletivo, que acionava a criação e a forma encontrava singularidade em cada artista. Hoje, pensando na maioria dos trabalhos que se vê, tanto nos discursos dos/as artistas, o substrato que impulsiona a criação é assunto individual, particular, subjetivo, mas encontra na forma um modo de se tornar assunto que diz respeito ao coletivo.

Se naquele momento anterior, era luta pelos direitos políticos que fez mover o desejo de uma experiência estética construtivista, para uma coletividade, nesse momento de crescente esmagamento dos direitos civis, a que temos sido submetidos, os trabalhos de arte que afirmam subjetividades - que ao mesmo tempo dão vozes a alteridades - tomam lugar ainda mais relevantes no que diz respeito à saúde política de uma sociedade civil. Nesse momento, como já o disse anteriormente, em que os parâmetros de pertencimento tem sido reduzido ao campo econômico, a experiência do sujeito (mais do que sua apresentação e/ou representação) inscrito nas mais diversas paisagens históricas, políticas e sociais é o programa estético coletivo mais urgente que temos hoje. 


\section{UMA PESQUISA CURATORIAL}

Sempre tive pudores de me apresentar como curadora, porque além de haver um recorrente equívoco de efeito hierárquico entre as/os agentes do campo da arte, eu não entendo curadoria como profissão, mas função que um/a artista, crítico/a, historiador/a, pesquisador/a, etc, podem vir a desempenhar. $E$ penso que tal função deve ser desempenhada com ética, em nome de um interesse coletivo - ainda que quase sempre seja inevitável o uso de recursos privados. Nesse sentido, só a pouco tempo, depois de muitos anos de trabalho desenvolvido como pesquisadora e crítica de arte, me vi com alguma proposição a ser apresentada que traz à tona todos esses questionamentos que tenho feito até então numa pergunta inevitável: como construir uma Nova Subjetividade?

Essa pesquisa tem encontrado diálogos com artistas que em seus trabalhos se apresentam como sujeitos, quando seus corpos são corpospolíticos dentro de paisagens históricas, culturais, sociais diversas. Vale entender esse corpo não só como corpo-encarnado, mas corpo-gesto, em que embora o corpo não esteja presente em cena, o gesto de sua passagem não deixa de trazer à superfície as narrativas de alteridade: sejam sobre imigração, gênero, raça, diversidade cultural, (in) tolerância religiosa, disparidade econômica, etc.

\section{ARTISTAS}

Rubiane Maia

http://cargocollective.com/rubianemaia

Rodrigo Braga

http://www.rodrigobraga.com.br/

Juliana Notari

http://issuu.com/juli09/docs/juliananotari\#

Tom N / Luísa Nóbrega

http://www.luisanobrega.com/

\section{Leonora Weissmann}

https://www.leonoraweissmann.org

\section{Thiago Martins de Melo}

http://www.mendeswood.com/artists/15/bio
Ícaro Lira

http://cargocollective.com/icarolira

\section{Luana Navarro}

http://www.luananavarro.com/

Mavi Veloso

http://maviveloso.tumblr.com/

Dalton Paula

https://daltonpaula.com/

Paulo Nazareth

http://artecontemporanealtda.blogspot.com.br/ Mai Fujimoto

http://maifujimoto.weebly.com/

\section{CONSIDERAÇÕES FINAIS}

Nesse marulho inevitável de vozes em uníssono segundo a maré das crises e novos fôlegos do capital, faço votos que tenhamos algum ânimo de resistir a tal movimento. Que nosso operariado esteja em vias de aniquilar esse sistema que teima em esmagar as convergências simbólicas que asseguram aquilo que ainda há de humano em nós.

\section{NOTAS}

I. Importante deixar claro a diferença do entendimento do Brasil como país geopolítico criado a partir da invasão de países imperialistas e o Brasil que deve ser entendido como território plurinacional em função dos seus povos originários. Na Bolívia esse reconhecimento de que há duas realidades de entendimento de fundação país a serem percebidas deu lugar a uma das leis mais belas já criadas: Ley Marco de la Madre Tierra y Desarrollo Integral para Vivir Bien, Bolívia, 2012.

II. É preciso separar as experiências catastróficas dos governos ditatoriais comunistas com o ideário/legado marxista que ainda serve de bússola frente à toda opressão capitalista.

III. No Brasil, com o legado dos movimentos Concretos e Neoconcretos, há uma tomada de consciência de que a fruição artística que prioriza a visão (a retina) é uma tradição europeia. Nossos movimentos preconizam que a fruição é participativa na qual a sensação e memória são 
ativadas por todos os modos de percepção do corpo apto a construir suas subjetividades.

IV. O Formalismo Vulgar foi um conceito que criei para discutir as formas e procedimentos artísticos que se repetem na arte contemporânea em função do mercado. Ao contrário dos movimentos modernistas/da modernidade, a contemporaneidade não criou um programa político-formal como cubismo, surrealismo, etc. Mas é possíveis identificar um formalismo, através das formas se repetem de maneira exaustiva (por isso, vulgar) pelo desejo de visibilidade dos/ as artistas que fazem caber seus trabalhos em projetos curatoriais, editais, becas, etc.

V. Trecho do seu livro "O que é Política?"

\section{SOBRE A AUTORA}

Ana Luisa Lima é crítica de arte, escritora e pesquisadora independente com foco em literatura e artes visuais - imagem e narrativa. Nasceu em Recife, atualmente baseada em Salta - Argentina. Faz parte do Conselho Curatorial do Museu de Arte Moderna Aloísio Magalhães - MAMAM. Editora da revista Tatuí de crítica de arte. Participou de debates, promoveu residências editoriais, ministrou laboratórios de escrita em crítica de arte e de análise dos discursos em artes visuais em vários estados brasileiros. Cocuradora do projeto ‘Poemas aos homens do nosso tempo - Hilda Hilst em diálogo', Programa Rede Nacional Funarte $9^{a}$ edição, 2013. Criadora da Cigarra Editora. Autora do livro '16'39" a extinção do reino deste mundo', São Paulo-SP, 2015. No audiovisual, lançou seu primeiro curta-metragem 'Zona Habitável' (13', Nova Lima - MG, Brasil, 2015). Já fez curadorias e publicou ensaios sobre artistas e fotógrafos como Farnese de Andrade (BR), Luiza Baldan (BR), Yuli Yamagata (BR), Marcelo Silveira (BR), Nazareno $(B R)$, Thiago Martins de Melo (BR), Felipe Abreu (BR), Carolina Krieger (BR), Luana Navarro (BR), Marco Maria Zanin (IT), Serge Huot (FR), Stéphane Pauvret e Christine Laquet (FR). Seus ensaios já foram traduzidos e publicados em espanhol, inglês, francês e italiano. 


\section{INSTRUÇÕES AOS AUTORES DE TEXTOS}

\section{INSTRUCTIONS FOR THE AUTHORS}

a) A Revista Arteriais aceitará textos em língua portuguesa, inglesa e espanhola. Todos os trabalhos deverão ser enviados por e-mail (revista.arteriais@ gmail.com) à: Editora da Revista Arteriais.

b) A Revista Arteriais não aceitará a submissão de mais de um artigo do mesmo autor e ou coautor para um mesmo número ou em números sucessivos da revista.

c) $\mathrm{O}(\mathrm{s})$ autor(es) que tiver(em) seu texto aprovado deverá(ão) enviar à Editoria da Revista uma Carta de Cessão (modelo Revista Arteriais), cedendo os direitos autorais para publicação, em formato eletrônico, em regime de exclusividade e originalidade do texto, pelo período de 2 (dois) anos, contados a partir da data de publicação do artigo na Revista.

d) Os Artigos deverão ter uma extensão entre $12 \mathrm{e}$ 24 páginas, incluindo resumo, abstract, palavraschave, texto e referências.

e) As Resenhas deverão apresentar entre quatro e seis páginas e as Entrevistas, de dez a quinze páginas.

f) Todos os trabalhos deverão ser enviados anexados ao e-mail revista.arteriais@gmail.com, em arquivo no programa Word for Windows 7.0;

g) Os textos dos Artigos, Resenhas e Entrevistas devem ser escritos em Times New Roman, fonte 12 , espaço 1.5 , margens 2,5 ;

h) A primeira página do texto dos Artigos deve conter:

TÍTULO

Resumo com cerca de 08 (oito) linhas, alinhamento à esquerda, contendo campo de estudo, objetivo, método, resultados e conclusões. O Resumo deve ser colocado logo abaixo do título e acima do texto principal.

Três (3) palavras-chaves, alinhamento justificado.

i) Em separado, deverá ser enviada uma página com o título dos Artigos, Resenhas e Entrevistas, a) ARTERIAIS Journal accepts papers in Portuguese, English and Spanish. All the papers might me sent by e-mail (revista.arteriais@gmail. com) to: Arteriais Journal Editor;

b) Arteriais Journal will not accept the submission of more than one paper from the same author and/ or co-author for the same issue or for a successive issue of the journal;

c) The author(s) with an approved paper must send to the Editor of the magazine a Grant Letter (Arteriais Journal model), assigning the publication rights, in electronic format, due to the regime of exclusivity and originality of the text for the term of 2 (two) years, which might be counted after the publication of the paper in the magazine;

d) The articles might have an extension of 12 to 24 pages, including abstract, English and Portuguese, keywords, text and references;

e) The reviews must have four to six pages and interviews must have ten to fifteen pages;

f) All the papers must be sent attached to the e-mail revista.arteriais@gmail.com, in Word for Windows 7.0 format;

g) All the Articles, Reviews and Interviews must be written in Times New Roman, font 12, space 1.5, margins 2.5;

h) The first page of the Articles must contain:

TITLE

Abstract with an average of 08 (eight) lines, aligned to the left, containing field of study, objectives, methodology, results and conclusion. The Abstract must come right after the title and before the main text.

Three (03) keywords, justified alignment

i) A separate sheet must be sent containing the title of the Article, Review and Interview, followed by the identification of the author(s) - full name, institution, function, address mail, phone and e-mail; 
seguido da identificação do(s) autor(es) - nome completo, instituição à qual está(ão) ligado(s), cargo, endereço para correspondência, fone e e-mail.

j) Incluir um Curriculum Vitae resumido com extensão máxima de 150 palavras, contendo as principais atividades na área do(s) autor(es) dos Artigos, Resenhas e Entrevistas.

k) Os textos devem ser escritos de forma clara e fluente.

l) As notas dos Artigos devem vir ao final do texto, em espaço simples, fonte tamanho 12 e alinhamento justificado.

m) Nos Artigos as citações com menos de três linhas devem ser inseridas no texto e colocadas entre aspas, seguidas da indicação da fonte pelo sistema autor-data. As citações que excederem três linhas devem ser colocadas em destaque, fonte 11 , espaço simples, entrada alinhada a $4 \mathrm{~cm}$ da margem, à esquerda, seguidas da indicação da fonte pelo sistema autor-data. No caso de citações de obras em língua estrangeira, essas devem aparecer no texto conforme o original podendo ser apresentadas as respectivas traduções para o português, em nota de rodapé, caso a língua de origem não seja espanhol ou inglês.

n) As indicações das fontes entre parêntesis, seguindo o sistema autor-data, devem ser estruturadas da seguinte forma:

Uma obra com um autor: (BARROS, 2011, p.30)

Uma obra com até três autores: (MANESCHY; SAMPAIO, 2007, p.120)

Uma obra com mais de três autores: (SARRAF et al., 2010, p.21-22)

Mesmo no caso das citações indiretas (paráfrases), a fonte deverá ser indicada, informando-se também a(s) página(s) sempre que houver referência não à obra como um todo, mas sim a uma ideia específica apresentada pelo autor.

o) Tabelas e quadros devem ser anexados ao texto, com a devida numeração (ex. Tabela 1, etc.). No corpo do texto deve ser indicado o lugar das tabelas.

p) Não serão aceitos artigos que estiverem fora das normas editoriais. O meta-artigo (template) pode ser visualizado em link da revista. A critério dos editores, poderá ser estabelecido um prazo j) Include a brief Resume with no more than 150 words, containing the main activities in the area of the author(s);

k) The texts must be written on a clear and objective way;

I) The notes of the article must come at the end of the text, space simple, font 12 and justified alignment;

m) For the Articles, the quotes with less than three lines must come along with the text between quotation marks, followed by the indication of the reference by the system author-date. The quotations that exceed three lines must be emphasized, font 11, space simple, entry aligned at $4 \mathrm{~cm}$ of the margin, to the left, followed by the indication of the reference by the system author-date. In the case of quotations from works in foreign language, they must come according the original reference and may be translated to Portuguese, in the area for the footnotes, if the original language is not Spanish or English;

n) The indications of the references between parentheses, following the system author-date, must be structured according to the following way:

One reference with one author: (BARROS, 2011, p.30)

One reference with until three authors: (MANESCHY; SAMPAIO, 2007, p.120)

One reference with more than three authors: (SARRAF et al., 2010, p.21-22)

Even in the case of indirect quotations (paraphrase), the reference must be pointed out, also informing the page(s), even if there is a reference not to the general work, but to a specific idea presented by the author;

o) Tables and charts must be attached to the text, with the proper numeration (ex. Table 1 etc.). The place of the Tables must be indicated in the text;

p) Articles that do not follow the Editorial rules will not be accepted. The meta-Article (template) might be visualized through a link on the homepage of the magazine. At the discretion of the editors, a certain period can be set so that the author(s) can make a revision of the text (corrections of references, quotations, grammar, and spelling). In this case, the failure to follow the deadline and 
determinado para que o(s) autor(es) efetue(m) uma revisão do texto (correções de referências, citações, gramática e escrita). Nesse caso, o não cumprimento do prazo e/ou a inadequação da revisão poderão implicar a não aceitação do trabalho para publicação.

\section{REFERÊNCIAS:}

Devem ser apresentadas em espaço simples, com alinhamento apenas à esquerda, seguindo as normas da ABNT abaixo exemplificadas.

\section{LIVROS}

SOBRENOME, Inicial do prenome(s) do(s) Autor(es). Título do trabalho: subtítulo [se houver]. edição [se não for a primeira]. Local de publicação: Editora, ano.

\section{PARTES DE LIVROS (CAPÍTULOS, ARTIGOS EM COLETÂNEAS, ETC.)}

SOBRENOME, Inicial do prenome(s) do(s) Autor(es) da Parte da Obra. Título da parte. In: SOBRENOME, Inicial do prenome(s) do(s) Autor(es) da Obra. Título do trabalho: subtítulo [se houver]. edição [se não for a primeira]. Local de publicação: Editora, ano. página inicial-final da parte.

\section{ARTIGOS EM PERIÓDICOS}

SOBRENOME, Inicial do prenome(s) do(s) Autor(es) do Artigo. Título do artigo. Título do Periódico, Local de publicação, número do volume, número do fascículo, página inicial-final do artigo, data

\section{TRABALHOS EM ANAIS DE EVENTOS CIENTÍFICOS}

SOBRENOME, Inicial do prenome(s) do(s) Autor(es) do Trabalho. Título do trabalho. In: NOME DO EVENTO, número do evento, ano de realização, local. Título. Local de publicação: Editora, ano de publicação. página inicial-final do trabalho.

\section{IMAGENS}

As imagens devem ser apresentadas numeradas, em arquivo (aproximado) de $21 \times 26 \mathrm{~cm}$ e 300 dpi, enviadas no formato JPG. As miniaturas das imagens com: autor, título, técnica, dimensões, fonte e autoria, devem vir no corpo do texto.
I or inadequacy of the review may lead to the rejection of the paper for publication.

\section{REFERENCES:}

They must be typed simple-spaced, aligned just to the left, following the rules from ABNT, as it follows:

\section{BOOKS}

AUTHOR'S LAST NAME, followed by the author's first name initial. Title of the work: subtitle [just if it has]. Edition [if it is not the first]. Place of publication: Publisher, year. Initial page - last page.

CHAPTER IN BOOKS (CHAPTERS, ARTICLES IN SELECTIONS ETC.)

AUTHOR'S LAST NAME, followed by the author's first name initial. In: AUTHOR'S LAST NAME, followed by the author's first name initial from the work. Title of the work: subtitle [just if it has]. Edition [if it is not the first]. Place of publication: Publisher, year. Initial page - last page.

\section{ARTICLES IN JOURNALS}

AUTHOR'S LAST NAME, followed by the author's first name initial. Title of the Journal, Place of publication, number of the volume, number of the issue, Initial page - last page.

\section{ARTICLES FROM SCIENTIFIC EVENTS ANNALS}

AUTHOR'S LAST NAME, followed by the author's first name initial. Title of the article. In: NAME OF THE EVENT, number of the event, year of realization, place. Title. Place of publication: Publisher, year of publication. , Initial page - last page.

\section{IMAGES}

Images must be submitted numbered, in a file (approx.) of $21 \times 26 \mathrm{~cm}$ and $300 \mathrm{dpi}$, sent in JPG format. Thumbnails of images also containing the following information for each one of them: author, title, technique, dimensions, source and authorship must be inside the text. 


\title{
INSTRUÇÕES AOS AUTORES DE PARTITURAS
}

\author{
INSTRUCTIONS FOR THE AUTHORS OF SCORES
}

A composição deve ser enviada em arquivo PDF com tamanho máximo de $5 \mathrm{MB}$. A partitura deve conter os seguintes elementos, de acordo com sua utilização: título da obra, instrumentação, autor, local e data de composição, letrista (se houver), indicações de andamento, compasso, dinâmica e articulação, e numeração dos compassos e páginas. Para composições que utilizam recursos especiais ou técnicas estendidas, recomenda-se o envio da bula. No caso de obras que utilizam suportes audiovisuais, os mesmos devem ser disponibilizados na forma de arquivos: MP3 para áudio, WMA para vídeo e JPG para figura. Estes arquivos devem ter tamanho máximo de $2 \mathrm{MB}$. Pode ser disponibilizada, também, uma gravação da composição em arquivo MP3 com tamanho máximo de $3 \mathrm{MB}$. Pede-se mini currículo e um texto crítico (uma lauda) apresentando o trabalho.
The composition must be sent in PDF format with the maximum of $5 \mathrm{MB}$. The score must contain the following elements, according to its use: title of the composition, instrumentation, author, date and place of composition, lyricist (if any), tempo markings, compass, dynamics and articulation, and numbering of bars and pages. For compositions using special features or extended techniques, it is recommended to send the leaflet. For works that use audiovisual media, they should be made available in the form of files: MP3 for audio, WMA for video and JPG for figure. These files must have a maximum size of $2 \mathrm{MB}$. It may also be provided a recording of the composition in MP3 file with maximum size 3 of $M B$. It is required a mini resume and a critical text (one page) presenting the work.

\section{INSTRUÇÕES AOS AUTORES DE PORTFOLIO}

\section{INSTRUCTIONS FOR THE AUTHORS OF PORTFOLIO}

Pede-se que sejam submetidas até 10 imagens, acompanhadas de mini currículo e de um texto crítico (uma lauda) apresentando o trabalho.

As imagens devem ser apresentadas numeradas, em arquivo (aproximado) de $21 \times 26 \mathrm{~cm}$ e $300 \mathrm{dpi}$, enviadas no formato JPG. Deve acompanhar um arquivo com documento em Word trazendo as miniaturas das imagens contendo, ainda, as seguintes informações para cada imagem: autor, título, técnica, dimensões, fonte e autoria. Caso haja dados desconhecidos, fazer uso de s.d., de acordo com a sequência de informações indicadas aqui.
It is required to be submitted up to 10 images accompanied by mini resume and a critical text (one page) presenting the work.

Images must be submitted numbered, in a file (approx.) of $21 \times 26 \mathrm{~cm}$ and $300 \mathrm{dpi}$, sent in JPG format. It is required a document in Word file with bringing the thumbnails of images also containing the following information for each one of them: author, title, technique, dimensions, source and authorship. If there is unknown data, use s.d., according to the sequence of information provided here. 


\section{CONTATO}

CONTACT

Universidade Federal do Pará

Instituto de Ciêncas da Arte

Programa de Pós-Graduação em Artes

Homepage: www.ppgartes.ufpa.br/site

Revista ARTERIAIS

Avenida Governador Magalhães Barata, n.) 611,

CEP 60060-281, Belém-Pará-Brasil

E-mail: revista.arteriais@gmail.com

Homepage: http://www.periodicos.ufpa.br/index.

php/ppgartes/index

Telefone: +55 - 91 - 3249-2905 


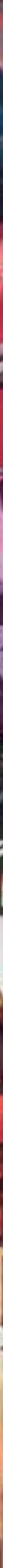

